Elaini Cristina Gonzaga da Silva

\title{
JURIDICIZAÇÃO DAS RELAÇõES INTERNACIONAIS \\ E \\ SOLUÇÃo DE CONTROVÉRSIAS: \\ Análise do Sistema Multilateral de Comércio
}

Dissertação apresentada para obtenção do título de Mestre.

Orientador: Prof. Dr. Alberto do Amaral Júnior

Universidade de São Paulo

Faculdade de Direito

São Paulo - 2007 
Elaini Cristina Gonzaga da Silva

JURIDICIZAÇÃo DAS RELAÇÕES INTERNACIONAIS E SOLUÇÃO DE CONTROVÉRSIAS: Análise do sistema multilateral de comércio

Dissertação apresentada à Faculdade de Direito da Universidade de São Paulo para obtenção do título de Mestre.

Área de concentração:

Aprovada em:

Banca Examinadora:

$\operatorname{Prof}(a) \cdot \operatorname{Dr}(a)$.

Instituição:

$\operatorname{Prof}(a) . \operatorname{Dr}(a)$.

Instituição:

Prof(a). Dr(a).

Instituição: 
Para a São Francisco 


\section{AGRADECIMENTOS}

Esta pesquisa não teria sido possível sem a colaboração de diversas pessoas e instituições. Assim, embora esta dissertação tenha sido escrita na terceira pessoa do singular, tal como estabelecem as regras do trabalho acadêmico, faço questão de registrar meus agradecimentos na primeira pessoa.

$E u$ agradeço à instituição que mais uma vez me acolheu e à qual dedico este trabalho: a Faculdade de Direito da Universidade de São Paulo. Eu agradeço também ao meu orientador, Prof. Alberto, que confiou em mim e teve a paciência necessária para me levar à conclusão desta pesquisa. Eu agradeço ainda à Prof. ${ }^{a}$ Elizabeth de Almeida Meirelles e ao Prof. Umberto Celli, os quais compuseram a mesa do meu exame de qualificação - a este professor, em especial, que me acompanha desde a graduação.

Pela oportunidade de viagem a Genebra, onde pude visitar a biblioteca da Organização Mundial do Comércio (OMC), e pelo apoio na cidade, eu agradeço ainda a Eduardo Escobedo, do Centro Internacional sobre Comércio e Desenvolvimento Sustentável (ICTSD) e a Michelle Ratton Sanchez, da Escola de Direito de São Paulo da Fundação Getulio Vargas (DIREITOGV). A esta $e u$ ainda agradeço pelo apoio e pelas oportunidades de discussão sobre comércio internacional e solução de controvérsias no âmbito do Grupo sobre Solução de Controvérsias do Instituto de Direito do Comércio Internacional e Desenvolvimento (IDCID) e no projeto Pontes entre o comércio e o desenvolvimento sustentável.

Ainda no âmbito do Grupo sobre Solução de Controvérsias do IDCID, eu agradeço aos demais integrantes, que permitiram reflexão mais aprofundada sobre solução de controvérsias e o processo de reforma do sistema da OMC: Adriana Dantas, Cynthia Kramer e André Bueno da Silveira.

$E u$ agradeço pelo apoio que meus amigos me deram ao longo do processo. Eu agradeço a André Tavares Barbosa, pela colaboração na preparação para a qualificação, a Priscila Spécie e a Adelina Novaes, pelos esclarecimentos metodológicos que me 
conduziram à conclusão desta pesquisa. Eu agradeço a Daniel Arbix, Evorah Lusci Cardoso e Yi Shin Tang, sem cuja colaboração, esta pesquisa não teria sido possível.

Em especial, eu agradeço a minha família: meus pais, Olavo e Maria; e meus irmãos, Júnior e Camila. Obrigada por estar lá, ou melhor, em Angatuba, quando precisei.

Muitas outras pessoas tiveram algum tipo de colaboração no caminho que me conduziu ao Direito, à escolha pela vida acadêmica e à entrada na pós-graduação. A todas eu devo meus agradecimentos.

Por fim, eu agradeço a Deus pela oportunidade recebida de realizar este trabalho e de ter conhecido todas essas pessoas. 


\section{Dóminus vobíscum}


Este trabalho teve por objetivo analisar o processo de juridicização do sistema multilateral de comércio, por meio da aplicação do modelo teórico de K. W. Abbott et al (2000) e contraposição dos resultados obtidos à análise do recurso a elementos normativos para justificação das decisões emanadas do sistema em procedimentos de solução de controvérsias em que foi suscitado o artigo $\mathrm{XX}(\mathrm{g})$ do GATT para defesa da medida questionada. Observou-se que, apesar do nível de juridicidade tenha permanecido praticamente o mesmo da passagem do GATT-1947 para a OMC, o recurso a elementos normativos para motivação das decisões foi incrementado. A hipótese demonstrada pelos resultados desta pesquisa é que o enfoque restrito no processo de institucionalização por meio de tratados não permite que sejam refletidas, no processo de juridicização, as alterações ocasionadas por outros elementos, como foi o caso, na presente pesquisa, das regras relativas à conformação dos órgãos auxiliares, à interpretação e à tomada de decisão - sejam elas originadas em tratados, costumes ou princípios.

Palavras-chave: sistema multilateral de comércio, sistema de solução de controvérsias, OMC, GATT, juridicização. 
This research aims at analyzing the legalization of the multilateral trade system, applying the theory developed by K. W. Аввотт et al (2000) and confronting the results with the level of recourse to normative elements to justify the decisions issued on disputes where Article $\mathrm{XX}(\mathrm{g})$ of GATT was used in defense of the challenged measure. Notwithstanding the fact that the legalization of the system did not alter from the GATT-1947 to WTO, more normative elements are used for motivation of the decisions taken by WTO. The research shows that excessive focus on the process institutionalization by treaties does not reflected the changes brought about by other elements, such as the configuration of the auxiliary organs - panels and Appellate Body - and the rules related to interpretation and decision making - be them customary international law or principles.

Key words: multilateral trade system, dispute settlement system, GATT, WTO, legalization. 


\section{LISTA DE ILUSTRAÇÕES}

Descrição

Página

Gráfico 1: Número de membros do sistema multilateral de comércio (1948-2005)

Quadro 1: Possíveis formas de juridicização das relações internacionais

Quadro 2: Delegação de autoridade nos mecanismos de solução de controvérsias

Quadro 3: Classificação dos argumentos utilizados para justificação das medidas questionadas com base no artigo XX(g) do GATT 


\begin{tabular}{|c|c|}
\hline Sigla & Descrição \\
\hline BIRD & Banco Internacional para a Reconstrução e o Desenvolvimento \\
\hline $\mathrm{CE}$ & Comunidades Européias \\
\hline $\mathrm{CEDH}$ & Corte Européia de Direitos Humanos \\
\hline $\mathrm{CIDH}$ & Corte Interamericana de Direitos Humanos \\
\hline CIJ & Corte Internacional de Justiça \\
\hline CITES & $\begin{array}{l}\text { Convenção para o Comércio Internacional das Espécies da Flora e } \\
\text { Fauna Selvagens em Perigo de Extinção (sigla em inglês) }\end{array}$ \\
\hline CPJI & Corte Permanente de Justiça Internacional \\
\hline ECOSOC & Conselho Econômico e Social da Organização das Nações Unidas \\
\hline EUA & Estados Unidos da América \\
\hline FMI & Fundo Monetário Internacional \\
\hline GATS & Acordo Geral sobre Comércio de Serviços (sigla em inglês) \\
\hline GATT & Acordo Geral de Comércio e Tarifas (sigla em inglês) \\
\hline ICITO & $\begin{array}{l}\text { Comissão Interina da Organização Internacional do Comércio (sigla } \\
\text { em inglês) }\end{array}$ \\
\hline ICSID & $\begin{array}{l}\text { Centro Internacional para a Solução de Disputas sobre Investimentos } \\
\text { (sigla em inglês) }\end{array}$ \\
\hline LDN & Liga das Nações \\
\hline MERCOSUL & Mercado Comum do Sul \\
\hline OIC & Organização Internacional do Comércio \\
\hline $\mathrm{OMC}$ & Organização Mundial do Comércio \\
\hline ONG & Organização não governamental \\
\hline ONU & Organização das Nações Unidas \\
\hline
\end{tabular}


Sigla

OSC

PICT

TJCE

TPA

TPI

TPR

UNCLOS

UNCTE

UNFCCC

\section{Descrição}

Órgão de Solução de Controvérsias da Organização Mundial do Comércio

Projeto sobre Cortes e Tribunais Internacionais da Universidade de Nova Iorque (sigla em inglês)

Tribunal de Justiça das Comunidades Européias

Tribunal Permanente de Arbitragem

Tribunal Penal Internacional

Tribunal Permanente de Revisão do Mercosul

Convenção das Nações Unidas sobre o Direito do Mar (sigla em inglês)

Conferência das Nações Unidas sobre Comércio e Emprego (sigla em inglês)

Convenção-Quadro das Nações Unidas sobre Mudança Climática (sigla em inglês) 
1. JURIDICIZAÇÃO E SOLUÇÃO DE CONTROVÉRSIAS

1.1. NOTAS INTRODUTÓRIAS 27

1.2. A JURIDICIZAÇÃO DAS RELAÇÕES INTERNACIONAIS 27

1.3. A DELEGAÇÃO DE AUTORIDADE 31

1.3.1. ACESSO AO MECANISMO 31

1.3.2. INDEPENDÊNCIA 34

1.3.3. EFEITOS DA DECISÃO

1.4. DelegaÇão de Autoridade nos PROCEDimentos de SOluÇÃo de CONTROVÉrSias NO DIREITO INTERNACIONAL $\quad 40$

1.4.1. PROCEDIMENTOS DE SOLUÇão DE CONTROVÉRSIAS NO DIREITO INTERNACIONAL 40

1.4.2. ClassificAÇ̃̃o dOS PROCEDIMENTOS EM RELAÇÃO AO GRAU DE DELEGAÇÃO DE AUTORIDADE 46

1.5. CONCLUSÃO 48

2. REGULAMENTAÇÃO DA SOLUÇÃO DE CONTROVÉRSIAS PELO SISTEMA MULTILATERAL DE COMÉRCIO

2.1. NOTAS INTRODUTÓRIAS 50

2.2. REGULAMENTAÇÃO DOS PROCEDIMENTOS

2.2.1. GATT-1947 51

2.2.1.1. Dificuldades na análise dos procedimentos de solução de controvérsias sob a vigência do GATT-1947 52

2.2.1.2. Regulamentação dos procedimentos de solução de controvérsias 53

$\begin{array}{lll}\text { 2.2.2. OMC } & 64\end{array}$

2.3. DELEGAÇ̃̃o DE AUTORIDADE NOS PROCEDIMENTOS DE SOLUÇÃO DE CONTROVÉRSIAS 65

2.3.1. ACESSO $\quad 66$

2.3.2. INDEPENDÊNCIA

$\begin{array}{lll}\text { 2.3.2.1. Subjetiva } & 74\end{array}$

2.3.2.2. Decisória $\quad 78$

2.3.2.3. Financeira 83 
3. UTILIZAÇÃO DE ELEMENTOS NORMATIVOS NAS DISPUTAS APRESENTADAS PERANTE O SISTEMA MULTILATERAL DE COMÉRCIO

3.1. NOTAS INTRODUTÓRIAS

3.2. CONTENCIOSOS SELECIONADOS

3.3. Dificuldades NA ANÁlise DAS DECISÕES DAS DISPUTAS NO SISTEMA MULTILATERAL DE COMÉRCIO

3.4. JUSTIFICAÇÃO EXTERNA DE MEDIDAS RELATIVAS À CONSERVAÇÃO DE RECURSOS NATURAIS EXAURÍVEIS

3.4.1. EUA - ATUM DO CANADÁ

3.4.2. CANADÁ - ARENQUE E SALMÃo

3.4.3. EUA - AUTOMÓVEIS

3.4.4. EUA - GASOLINA 105

3.4.5. EUA - CAMARÕES 109

3.5. CLASSIFICAÇÃO DA ARGUMENTAÇÃO UTILIZADA PARA JUSTIFICAÇÃO EXTERNA 119

3.6. CONCLUSÃO

CONSIDERAÇÕES FINAIS 125

REFERÊNCIAS BIBLIOGRÁFICAS

APÊNDICE A - ORGANOGRAMA DO GATT-1947 (1948-1994)

APÊNDICE B - ORGANOGRAMA DA OMC (1995-2005)

APÊNDICE D - TERMOS DE REFERÊNCIA E MOTIVAÇÃO PARA ESTABELECIMENTO DE PAINEL NAS DISPUTAS ANALISADAS

ANEXO A - DISPOSITIVOS DA CARTA DA OIC RELATIVOS À SOLUÇÃO DE CONTROVÉRSIAS 
ANEXO E - DECLARAÇÃO DE 1982

ANEXO F - DECISÃO DE 1984

ANEXO G - DECISÃO DE 1989

219

ANEXO H - DECISÃO DE 1994 


\section{INTRODUÇÃO}

Em 1944, ainda no contexto da Segunda Guerra Mundial, foi concluído, em Bretton Woods, Estados Unidos da América (EUA), um acordo internacional cujo escopo consistia em criar um ambiente propício para a maior cooperação entre os países na área econômica internacional, baseado no estabelecimento de três instituições internacionais.

O Fundo Monetário Internacional (FMI) seria a primeira dessas instituições, cujo objetivo consistia na manutenção da estabilidade das taxas de câmbio e no auxílio aos países com problemas em suas balanças de pagamento, por meio da disponibilização de fundos especiais. A segunda instituição criada foi o Banco Internacional para a Reconstrução e o Desenvolvimento (BIRD), cuja função era fornecer os capitais necessários para a reconstrução dos países atingidos pela guerra e deu lugar ao desenvolvimento do complexo do atual Banco Mundial. A última das instituições, cujas negociações se davam no âmbito do Conselho Econômico e Social da Organização das Nações Unidas (ECOSOC), deveria ser a Organização Internacional do Comércio (OIC). Esta organização teria como objetivo a coordenação e a supervisão da negociação de um novo regime para o comércio mundial baseado nos princípios do multilateralismo e do liberalismo.

Embora os dois primeiros tenham sido criados com sucesso, a última organização não foi levada a efeito, devido à resistência do Congresso estadunidense em ratificar sua carta de criação. Antes mesmo da conclusão da Carta de Havana, o Acordo Provisório negociado concomitantemente à OIC assinado por 23 países em 1947, dentre os quais o Brasil, passou a vigorar e regulamentar o comércio internacional de suas partes contratantes ${ }^{1}$. Esse acordo denominava-se Acordo Geral sobre Tarifas e Comércio, ou, em inglês, General Agreement on Tariffs and Trade (GATT) ${ }^{2}$, e, de simples acordo, passou a

\footnotetext{
${ }^{1}$ A expressão "partes contratantes" refere-se aos Estados que eram signatários do acordo individualmente. Por sua vez, a expressão "Partes Contratantes" designa a assembléia de signatários que decidiam em conjunto.

${ }^{2}$ Nesta pesquisa o termo GATT é utilizado nas acepções seguintes: como GATT-1947, refere-se tanto à estrutura criada para aplicar o acordo que vigorou entre 1947 e 1994 quanto a este acordo; como GATT-
} 
ter uma estrutura administrativa conduzida por um Secretariado com sede em Genebra ${ }^{3}$ diante da impossibilidade de criação da OIC.

A regulamentação do comércio internacional, tal como é hoje concebido, foi estabelecida ao longo dos anos e de rodadas de negociações multilaterais realizadas no âmbito do GATT. Assim, a Organização Mundial do Comércio (OMC), que conta, hoje, com 149 membros e foi criada em 1995, configura-se como um dos frutos da Rodada Uruguai de negociações comerciais multilaterais (1986-1994).

De acordo com o artigo III do Acordo Constitutivo da OMC [Acordo de Marraqueche], suas funções compreendem:

1. Administrar os acordos abrangidos ${ }^{4}$;

2. Estabelecer ambiente para a negociação de regras de liberalização e de regulação do comércio internacional;

3. Administrar o Entendimento sobre Solução de Controvérsias;

1994, para designar o acordo tal como estabelecido pelas partes para vigorar a partir de 1995; e, como GATT, para fazer referência aos dois períodos.

${ }^{3}$ Cf. J. H. JACKSON (1997:653): "The GATT is truly a perplexing institution. It became what it was never intended to be - the central international organization for world trade - after the 1948 charter of the International Trade Organization failed to come into force".

${ }^{4}$ Os acordos compreendidos pela Ata Final em que se Incorporam os Resultados da Rodada Uruguai de Negociações Comerciais Multilaterais são os seguintes: Acordo de Marraqueche; os acordos constantes do Anexo 1, que inclui os Anexos 1A (relativo aos acordos multilaterais sobre o comércio de bens), $1 \mathrm{~B}$ (Acordo Geral sobre o Comércio de Serviços) e 1C (Acordo sobre Aspectos dos Direitos de Propriedade Intelectual Relacionados ao Comércio); o Entendimento Relativo às Normas e Procedimentos sobre Solução de Controvérsias [Entendimento sobre Solução de Controvérsias] presente no Anexo 2; o Mecanismo de Exame de Políticas Comerciais, constante no Anexo 3; e os acordos plurilaterais incluídos no Anexo 4. O Anexo 1A é composto pelos seguintes acordos: GATT-1994; Entendimento sobre a Interpretação do Artigo II:1(b) do GATT-1994; Entendimento sobre a Interpretação do Artigo XVII do GATT-1994; Entendimento sobre as Disposições Relativas a Balanço de Pagamentos do GATT-1994; Entendimento sobre a Interpretação do Artigo XXIV do GATT-1994; Entendimento sobre Derrogações de Obrigações sob o GATT-1994; Entendimento sobre a Interpretação do Artigo XXVIII do GATT-1994; Entendimento sobre a Interpretação do Artigo XXXV do GATT-1994; Protocolo de Marraqueche do GATT-1994; Acordo sobre Agricultura; Acordo sobre Aplicação de Medidas Sanitárias e Fitossanitárias; Acordo sobre Têxteis e Vestuário; Acordo sobre Barreiras Técnicas ao Comércio; Acordo sobre Medidas de Investimento Relacionadas ao Comércio; Acordo sobre a Implementação do Artigo VI do GATT-1994; Acordo sobre Medidas de Investimento Relacionadas ao Comércio; Acordo sobre a Implementação do Artigo VII do GATT-1994; Acordo sobre Inspeção Pré-Embarque; Acordo sobre Regras de Origem; Acordo sobre Procedimentos para o Licenciamento de Importações; Acordo sobre Subsídios e Medidas Compensatórias; e o Acordo sobre Salvaguardas. Conforme disposto no Acordo de Marraqueche, apenas as línguas inglesa, francesa e espanhola são consideradas autênticas na OMC. Deste modo, salvo menção expressa em contrário, as versões em português apresentadas nesta pesquisa são aquelas constantes do Decreto 1.355 , de 30 de dezembro de 1994, que promulgou os resultados da Rodada Uruguai no ordenamento jurídico brasileiro. 
4. Administrar o Mecanismo de Exame das Políticas Comerciais (TPRM, na sigla em inglês); e

5. Cooperação com o FMI e o Banco Mundial, com o objetivo de alcançar maior coerência na formulação das políticas econômicas em escala mundial.

O gráfico a seguir indica a evolução do número de Estados integrantes do sistema multilateral de comércio ${ }^{5}$ :

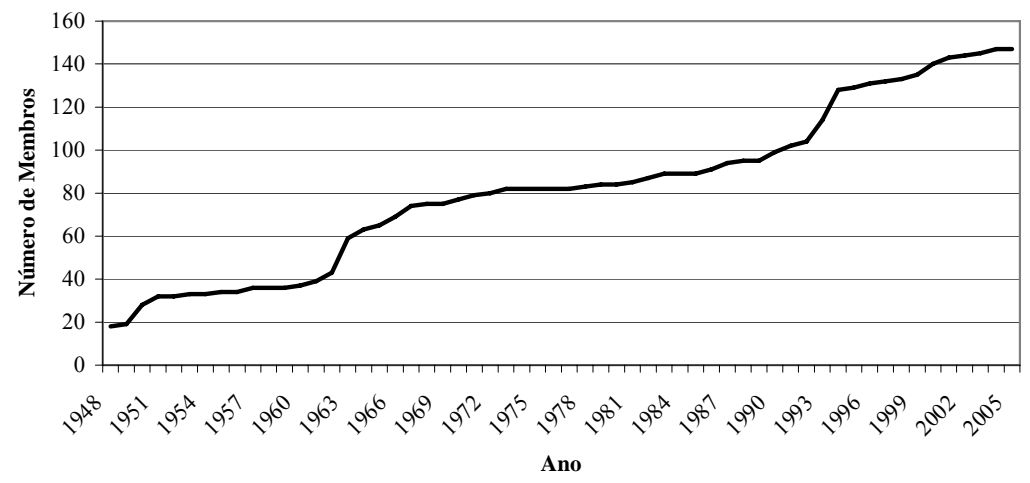

Gráfico 1: Número de membros do sistema multilateral de comércio (1948-2005)

Dentre as inovações da OMC, encontra-se o Órgão de Solução de Controvérsias (OSC) criado pelo Entendimento sobre Solução de Controvérsias. A tal órgão compete proceder à amigável composição de conflitos surgidos entre os membros da organização com relação à interpretação e à aplicação das regras dos diversos acordos da OMC.

Quando da adoção do GATT-1947, seu sistema de solução de controvérsias era regido por seus artigos XXII (o qual trata de consultas entre os membros) e XXIII (em caso de dano e prejuízo $)^{6}$, sem regulamentação detalhada, devido ao fato de que deveria ter sido aplicado apenas provisoriamente. Ao longo da vigência do sistema, os procedimentos foram modificados pela prática, a princípio, e, posteriormente, por outros instrumentos.

De modo geral, este sistema era marcado pela grande influência exercida pelas partes contratantes sobre seus procedimentos. Neste sentido, por exemplo, bastava que o

${ }^{5} \mathrm{O}$ sistema multilateral de comércio consiste no conjunto de regras e práticas compreendidas no âmbito do GATT-1947 e da OMC.

${ }^{6}$ A tradução para o português da versão original dos referidos artigos encontra-se no Anexo B. 
Estado perdedor votasse contra a adoção do relatório para que este não fosse adotado pelo Conselho Geral.

O ponto de inflexão nesta evolução deu-se apenas com o Entendimento sobre Solução de Controvérsias, o qual constitui sistema de solução de controvérsias ${ }^{7}$ único para todas as disputas que surgirem entre os membros da OMC sobre qualquer um dos acordos abrangidos pela organização.

Ademais, o Entendimento sobre Solução de Controvérsias instituiu o Órgão de Apelação, figura inexistente no âmbito do GATT. Além de conferir caráter permanente ao Órgão de Apelação, o Entendimento sobre Solução de Controvérsias, por meio de seu artigo 17.6, estabeleceu que tal órgão é competente para receber as apelações dos Membros relativas às questões de direito suscitadas nos relatórios dos painéis e às interpretações jurídicas por estes formuladas. Ao longo da existência do OSC, já lhe foram apresentados mais de trezentos pedidos de consultas, dos quais mais de cem tiveram algum relatório adotado.

Uma vez, entretanto, que esta organização não foi criada em um vazio jurídico, mas dentro de um sistema descentralizado e não hierarquizado de produção de direito, o elevado número de disputas trazidas para apreciação do OSC suscita uma série de problemas, dentre os quais se ressalta a definição das fontes de Direito a serem utilizadas pelos painéis e pelo Órgão de Apelação em suas decisões.

Não obstante a ampliação dos temas compreendidos da gênese do sistema multilateral de comércio até os dias atuais e da criação de pontos de conexão com valores outros que não a liberalização comercial, os acordos abrangidos pela OMC não fornecem resposta ao problema das fontes para decisão das disputas.

De fato, os termos de referência dos órgãos auxiliares do OSC - os painéis e o Órgão de Apelação - definem, apenas, que a questão a ser analisada deve ser examinada à luz das disposições específicas do GATT-1994 e demais acordos citados pelo demandante no pedido de estabelecimento de painel. Além disso, o artigo 3.2 do Entendimento sobre Solução de Controvérsias estabelece, expressamente, que a interpretação dos acordos

\footnotetext{
${ }^{7}$ Nesta pesquisa, definem-se procedimentos de solução de controvérsias como o conjunto de regras e práticas elaboradas com o intuito de criar procedimentos específicos para pôr fim a uma disputa entre partes em conflito sobre aspectos de fato e/ou de direito. Os diversos procedimentos de solução de controvérsias do Direito Internacional encontram-se descritos no item 2.3.1. Por sua vez, sistemas de solução de controvérsias são definidos como o conjunto de regras e práticas que combinam um ou mais procedimentos de solução de controvérsias para viger em determinado regime.
} 
abrangidos deve seguir as normas consuetudinárias do direito internacional público sobre interpretação ${ }^{8}$.

Em linhas gerais, há duas correntes principais com relação à possibilidade de utilização de normas produzidas fora do âmbito do sistema multilateral de comércio nas decisões prolatadas nos procedimentos de solução de controvérsias deste. A primeira não concebe a utilização de qualquer norma não diretamente vinculada pelos tratados da $\mathrm{OMC}$, como é o caso de, por exemplo, D. MCRAE (1996) e R. Howse (2002). A segunda advoga a possibilidade de o fazer, dentre cujos pensadores se ressaltam J. PAUWELYN (2001, 2002; 2005) e G. MARCEAU (1999; 2002).

Os filiados à visão integrada do direito internacional são atraídos, de forma especial, pelo trabalho de J. PAUWELYN (2005). De acordo este autor, como as normas comerciais são bilaterais (e não erga omnes ou erga omnes partes), qual regra vigente na relação entre as duas partes de uma disputa pode ser aplicada e implementada pelo sistema de solução de controvérsias da OMC.

Após análise mais detalhada, contudo, percebe-se que esta posição pressupõe tanto a integração de todos os sistemas e regimes do direito e das relações internacionais quanto não considera a problemática da jurisdição e da competência de mecanismos de solução de controvérsias no direito internacional.

Diante deste cenário, o objetivo da presente pesquisa consiste em contribuir para o esclarecimento deste problema a partir de que considera imprescindível para tanto: a definição dos elementos relacionados à formação de sistemas jurídicos no cenário internacional.

\footnotetext{
${ }^{8} \mathrm{O}$ texto do referido artigo estatui expressamente: "The Members recognize that it serves to preserve the rights and obligations of Members under the covered agreements, and to clarify the existing provisions of those agreements in accordance with customary rules of interpretation of public international law" (grifo da autora). No mesmo sentido, a versão em francês declara: «Les Membres reconnaissent qu'il a pour objet de préserver les droits et les obligations résultant pour les Membres des accords visés, et de clarifier les dispositions existantes de ces accords conformément aux règles coutumières d'interprétation du droit international public » (grifo da autora). Na versão em espanhol, contudo, o termo consuetudinárias passa a ser interpretado de modo diverso: "Los Miembros reconocen que ese sistema sirve para preservar los derechos y obligaciones de los Miembros en el marco de los acuerdos abarcados y para aclarar las disposiciones vigentes de dichos acuerdos de conformidad con las normas usuales de interpretación del derecho internacional público" (grifo da autora). Esta parece ter sido a origem para a tradução para a língua portuguesa, visto que a versão incorporada ao ordenamento brasileiro segue a mesma linha: "Os Membros reconhecem que esse sistema é útil para preservar direitos e obrigações dos Membros dentro dos parâmetros dos acordos abrangidos e para esclarecer as disposições vigentes dos referidos acordos em conformidade com as normas correntes de interpretação do direito internacional público" (grifo da autora). Os resultados da Rodada Uruguai foram incorporados ao ordenamento brasileiro pelo Decreto n. ${ }^{\circ} 1.355$ de 30 de dezembro de 1995.
} 
A hipótese demonstrada pelos resultados desta pesquisa é que o enfoque restrito no processo de institucionalização (ou seja, na assinatura de tratados) não permite que sejam refletidas, no processo de juridicização das relações, as alterações ocasionadas por outros elementos, como foi o caso, na presente pesquisa, das regras relativas à conformação dos órgãos auxiliares, à interpretação e à tomada de decisão - sejam elas originadas em tratados, costumes ou princípios.

A fim de alcançar seu objetivo, esta pesquisa é composta por introdução, três capítulos e considerações finais.

No primeiro capítulo, procede-se à explicação da teoria da juridicização de K. W. Aввотт et al (2000) ${ }^{9}$, modelo teórico escolhido como primeiro parâmetro de análise. De acordo com este modelo, juridicização é o processo de institucionalização caracterizada por três fatores: obrigação, especificidade e delegação.

$\mathrm{Na}$ base dessa teoria, encontra-se a idéia de que a introdução de normas secundárias em um conjunto de normas primárias significa a passagem do mundo préjurídico para o jurídico, por conferir-lhe certeza, dinamicidade e eficiência (HART:1997, 94). Deste modo, a cada etapa do processo de juridicização, atribui-se determinado grau de juridicidade ao sistema.

No que se refere à relação entre esta teoria e sistemas de solução de controvérsias, verifica-se que o termo delegação está relacionado à autorização para que Terceiros ${ }^{10}$ possam implementar, interpretar e aplicar regras, bem como resolver as disputas que lhe são submetidas e, ainda, produzir novas regras(ABBOTT ET AL:2000, 415). Desta forma, passa a ser um dos elementos fundamentais no processo de juridicização de um sistema.

A opção pela teoria de K. W. Аввотт et al (2000) deve-se a dois fatores. Em primeiro, o referido modelo foi elaborado de modo a ensejar sua aplicação em pesquisas

\footnotetext{
${ }^{9}$ O termo juridicização é uma tradução livre da palavra legalization utilizada pelos referidos autores em sua teoria. Por sua vez, os originais dos termos obrigação, especificidade e delegação são, respectivamente, obligation, precision e delegation. As mesmas definições e os mesmos termos são utilizados ao longo dos demais artigos que compõem a publicação, v., por exemplo, os seguintes artigos: J. GoLDSTEIN, (2000), J. M. SMith (2000), R. O. KEOHANE, A. MORAVCSIK, A.-M. SLAUGHTER (2000) e M. KAHLER (2000). Todos estes artigos aplicam a teoria e a desenvolvem. Deste modo, a referência ao modelo juridicização indica o conjunto desta obra.

${ }^{10} \mathrm{O}$ termo Terceiro com letra maiúscula, nesta pesquisa, é utilizado em referência ao indivíduo super partes que não se confunde com as terceiras partes da disputa.
} 
empíricas - como foi realizado, por exemplo, nos artigos do número da revista em que foi publicado. Esta característica fez com que a teoria ganhasse destaque nos estudos internacionais e fosse amplamente divulgada.

No segundo capítulo, é realizada a aplicação empírica do modelo teórico para análise do sistema multilateral de comércio. As fontes primárias utilizadas compreendem documentos emitidos no âmbito do GATT-1947 e da OMC - principalmente, resoluções e relatórios. Nos casos em que não foi possível a definição inequívoca dos elementos necessários para a pesquisa, recorreu-se a fontes secundárias, como artigos e declarações de especialistas em comércio internacional e atores envolvidos com o sistema multilateral de comércio (como, por exemplo, representantes de governos e funcionários do Secretariado).

Observa-se que o processo de atribuição de categorias aos elementos identificados no processo de pesquisa obedeceu aos critérios de categorização indicadas por L. BARDIN (1995:120): exclusão mútua, homogeneidade, pertinência, objetividade e produtividade.

No terceiro capítulo, por sua vez, objetivou-se a constituição de contraprova às conclusões aduzidas no capítulo anterior com relação ao grau de juridicidade do sistema multilateral de comércio. Para tanto, procedeu-se à análise de decisões emanadas do sistema de solução de controvérsias para identificação do recurso a elementos normativos para justificação externa ${ }^{11}$ da cláusula analisada.

Dentre as decisões prolatadas nas controvérsias apresentadas perante o sistema multilateral de comércio, foram selecionadas aquelas em que se suscita o artigo $\mathrm{XX}(\mathrm{g})$ do GATT para justificação da medida questionada. Explica-se.

De modo geral, as disputas apresentadas, no âmbito da OMC, podem versar sobre violação dos acordos abrangidos pelos Membros ou sobre o prejuízo ou dano sofrido por um membro ainda que outro não viole expressamente os acordos. Dentre estes dois tipos, prevalece o primeiro. No exame das medidas questionadas neste tipo de disputa, as partes podem tanto demonstrar que não se verificou a violação quanto que, embora esta tenha ocorrido, ela encontra respaldo em algum excludente previsto pelos acordos - visto

\footnotetext{
${ }^{11}$ De acordo com R. ALEXY (1989), a justificação externa de um discurso jurídico consiste na verificação da correção das premissas apresentadas para justificação interna. Observa-se que a utilização da distinção apresentada na obra do referido autor, nesta pesquisa, não implica na adoção de seus conceitos.
} 
que a legislação nacional não excusa o cumprimento de obrigação derivada de tratado internacional.

Dentre os excludentes, citam-se: medidas de defesa comercial, questões relativas a áreas de integração econômica, problemas com balanço de pagamento, exceções do artigo XXI do GATT e exceções do artigo XX do GATT. Observa-se que, na OMC, não houve nenhum caso relativo à exceção de obrigações nem em razão de problemas de balanço de pagamentos nem pelo artigo XXI do GATT; além disso, no caso de conflito entre as normas de uma área de integração econômica e os acordos da $\mathrm{OMC}$, estes prevalecem, em razão de serem a norma última à qual aqueles devem se adequar.

Por sua vez, aproximadamente $35 \%{ }^{12}$ dos casos apresentados perante o sistema de solução de controvérsias da OMC versam sobre a aplicação de medidas de defesa comercial $^{13}$ pelos ordenamentos internos dos membros da organização. Mais uma vez, no caso de conflito entre ambos, prevalece a normativa do sistema multilateral de comércio.

Embora o artigo XX não tenha sido objeto de tantos casos quanto as medidas de defesa comercial, observa-se que sua aplicação é mais complexa em face dos demais, pelo fato de tal artigo estabelecer um elo de conexão entre os valores relativos à liberalização comercial consubstanciados nas regras da $\mathrm{OMC}$ e aqueles referentes a valores que são objeto de sistemas diferentes.

Dentre todas as alíneas do artigo XX, somente a $b$, a $d$, a $g$ e a $h$ foram suscitas em alguma disputa apresentada perante o sistema multilateral de comércio. Dentre os casos da alínea XX, ressalta-se a maior ocorrência daqueles relacionados à conservação ou à proteção do meio ambiente ou da vida humana, animal ou vegetal. A redação do artigo XX do GATT relevante para a proteção ou conservação do meio ambiente ou da vida ou saúde humana, animal ou vegetal é a seguinte ${ }^{14}$ :

Desde que essas medidas não sejam aplicadas de forma a constituir quer um meio de discriminação arbitrária, ou

12 Cálculo realizado a partir dos dados disponíveis na página eletrônica da OMC. Disponível em: $<$ http://www.wto.org/english/tratop_e/dispu_e/dispu_status_e.htm>. Acesso em: 21 jan. 2007.

${ }^{13}$ Estas compreendem as medidas antidumping, os direitos compensatórios e as salvaguardas. Tais medidas são regulamentadas, respectivamente, pelos artigos VI, XVI e XIX do GATT-1994.

${ }^{14}$ Redação original presente no Decreto que incorporou o GATT-1947 ao ordenamento jurídico brasileiro: Decreto n. 313, de 30 de julho de 1948. O texto também se encontra disponível em: $<$ http://www2.mre.gov.br/dai/home.htm/multicom>. Acesso em: 13 jan. 2007. 
injustificada, entre os países onde existem as mesmas condições, quer uma restrição disfarçada ao comércio internacional, disposição alguma do presente capitulo será interpretada como impedindo a adoção ou aplicação, por qualquer Parte Contratante, das medidas:

b) necessárias á proteção da saúde e da vida das pessoas e dos animais e á preservação dos vegetais;

g) relativas à conservação dos recursos naturais esgotáveis, se tais medidas forem aplicadas conjuntamente com restrições à produção ou ao consumo nacionais;

Ao longo de todo o processo de desenvolvimento do sistema, não se modificou o Artigo XX, que passou, desde a criação da OMC, a ser aplicável a todos os Acordos de Bens do Anexo 1A do Acordo da OMC. Além disso, um dispositivo semelhante foi inserido no Acordo Geral sobre Comércio de Serviços (GATS, sigla em inglês), em seu Artigo XIV.

A opção pela análise dos casos em que se suscita o artigo XX(g) deu-se por duas razões. Em primeiro lugar, há distribuição mais ampla do número de disputas pelo período de análise (1947-2005) e, assim, maior representatividade. Isso porque, no GATT1947, apenas um caso cuja decisão foi adotada pelas Partes Contratantes discutiu a aplicação do artigo XX(b) do acordo. Por outro lado, no GATT-1947, há três disputas em que surgiu a alínea $g$ do referido artigo (dentre as quais, duas seguiram o Entendimento de 1979, e uma foi regida pela Decisão de 1989), em comparação com duas no âmbito da OMC.

Em segundo lugar, esta alínea suscita o confronto valorativo entre a liberalização comercial, propugnada pelo sistema multilateral de comércio, e a proteção do meio ambiente. Este confronto exige maior sofisticação argumentativa, diante da indefinição de como se dá a relação entre as normas produzidas no âmbito da OMC e em outros foros - o que exige um exercício de interpretação e integração mais acentuado do que em outros casos.

Deste modo, foram selecionadas para análise as decisões emanadas, no período entre 1948 e 2005, nos casos em que foram questionadas medidas cujo objetivo (tal como alegado pelos países demandados) era conservar recursos naturais exauríveis com fundamento no artigo XX(g) do GATT ${ }^{15}$.

\footnotetext{
${ }^{15}$ A análise do caput não seria possível, porque ele não chegou a ser analisado em todos os casos.
} 
Dentre os elementos das decisões selecionadas, a pesquisa empírica do terceiro capítulo focalizará os argumentos utilizados para justificação externa da caracterização das medidas questionadas como "relativas à proteção de recursos naturais exauríveis".

Embora não se pretenda estender os resultados destas decisões para o universo das decisões do sistema multilateral de comércio, elas são representativas de seu próprio universo e foram selecionadas com base nos três critérios estabelecidos por L. BARDIN (1995:97): exaustividade, representatividade e homogeneidade. Deste modo, sob a vigência do GATT-1947, foram selecionados os seguintes casos:

1. United States - Prohibition of Imports of Tuna and Tuna Products from Canada [EUA - Atum];

2. Canada - Measures Affecting Exports of Unprocessed Herring and Salmon [Canadá Arenque e Salmão];

3. United States - Taxes on Automobiles [EUA - Automóveis].

Dentre as disputas apresentadas perante o OSC/OMC, por sua vez, os seguintes casos detêm os requisitos selecionados:

1. DS 2-4: United States - Standards for Reformulated and Conventional Gasoline [EUA - Gasolina]; e

2. DS58: United States - Import Prohibition of Certain Shrimp and Shrimp Products [EUA - Camarões];

Para tal pesquisa, foram selecionados os relatórios dos painéis e, quando existente, do Órgão de Apelação. A partir destes documentos, foram colhidos os argumentos das partes das controvérsias, pois suas petições são confidenciais. Embora alguns países divulguem, voluntariamente, suas próprias petições não há previsibilidade quanto ao seu comportamento ${ }^{16}$. Deste modo, os referidos documentos constituem fonte primária para análise dos argumentos avançados pelos julgadores e secundária com relação à argumentação das partes.

Por sua vez, os argumentos analisados foram organizados nas seguintes categorias: tratados, costume, princípios, jurisprudência, doutrina, documentos de

\footnotetext{
${ }^{16}$ Neste sentido, por exemplo, embora as Comunidades Européias (CE) divulgassem, costumeiramente, suas petições, não o fizeram no caso dos pneus - Brazil - Measures Affecting Imports of Retreaded Tyres (DS332).
} 
organizações internacionais e afirmações empíricas. A atribuição de categorias aos elementos identificados foi realizada em obediência às regras de exclusão mútua, homogeneidade, pertinência, objetividade e produtividade (BARDIN: 1995,120).

Não se pretende, com este mapeamento, proceder-se à crítica do sentido da posição das partes da disputa e da decisão, mas apenas identificar o nível de recurso a elementos normativos nas decisões.

Por fim, nas considerações finais, é realizada a análise crítica das conclusões desenvolvidas nos três capítulos. Deste modo, busca-se verificar se, de fato, o grau de juridicização do sistema multilateral de comércio identificado no capítulo 2 é refletido na juridicidade das decisões analisadas no capítulo 3.

Esta pesquisa utilizou a regra autor-data para referência no corpo do texto na seguinte seqüência: (AUTOR:data, página). No que se refere aos documentos de organizações internacionais, contudo, utilizou-se o número do documento em vez do ano de sua edição,como meio de facilitar a busca nas referências.

Com relação aos elementos incluídos nas referências às decisões da Corte Internacional de Justiça (CIJ), à do Centro Internacional para a Solução de Disputas sobre Investimentos (ICSID, sigla em inglês) e aos relatórios dos painéis e do Órgão de Apelação do sistema multilateral de comércio, foram adotados dois critérios.

Para citação ao longo do texto, foi utilizado o nome da disputa. Apenas os nomes das disputas analisadas no terceiro capítulo foram abreviados e traduzidos para o português, os demais, encontram-se na versão oficial. Para inclusão nas referências finais, foi observada a regra referente a decisões judiciais estabelecida pela norma da ABNT referida acima.

No que se refere à citação dos documentos do GATT-1947 e da OMC, foi utilizada a seguinte seqüência: organização, número do documento e página ou parágrafo (§) - ou seja, (ORGANIZAÇÃO: data, página/parágrafo). Apenas no relatório do Órgão de Apelação no caso EUA - Gasolina foi utilizada a referência ao número de página, visto que os parágrafos não estavam numerados.

O elemento de entrada nas referências aos tratados, por sua vez, é o próprio nome do tratado, seguido da data de assinatura e local em que pode ser acessado. 
Observa-se que as referências utilizadas nos relatórios dos painéis e do Órgão de Apelação que foram transcritas no terceiro capítulo não se encontram nas referências bibliográficas desta pesquisa. 


\section{JURIDICIZAÇÃO E SOLUÇÃO DE CONTROVÉRSIAS}

\subsection{Notas introdutórias}

O primeiro passo desta pesquisa consiste em apresentar os elementos conceituais da teoria da juridicização de K. W. AвBOTT et al (2000). Este será o objetivo deste capítulo.

Primeiramente, será apresentada tal teoria e seus elementos conceituais (item 1.2). Dentre os elementos da juridicização que serão apresentados, o fator "delegação de autoridade" será retomado especificamente para desenvolvimento de seu conteúdo (item $1.3)$.

Em seguida, após apresentados os diversos procedimentos de solução de controvérsias (item 1.4.1), estes serão classificados de acordo com o grau de juridicidade que lhes pode ser atribuído, conforme o quadro desenvolvido.

\subsection{A juridicização das relações internacionais}

O fenômeno da proliferação de mecanismos judiciais e quasi-judiciais de solução de controvérsias ${ }^{17}$ corresponde à passagem da autotutela para a autocomposição e

\footnotetext{
${ }^{17}$ De acordo com o resultado de pesquisa realizada pelo Projeto sobre Tribunais e Cortes Internacionais (PICT, sigla em inglês) da Universidade de Nova Iorque, hoje, há mais de vinte órgãos jurisdicionais que preenchem, com certa flexibilidade, aos seguintes critérios, Cf. C. P. R. ROMANO (1998-1999:713): i. serem permanentes; ii. terem carta constitutiva; iii. decidir com base no Direito Internacional; iv. terem regras de procedimentos previamente estabelecidas; v. terem decisões vinculantes; vi. indicação dos julgadores é realizada previamente às controvérsias submetidas; e vii. pelo menos uma das partes é Estado. Se alguns desses critérios forem aplicados de forma flexível, de modo a permitir a inclusão de órgãos quasi-judiciais, mecanismos de supervisão de implementação e outros mecanismos de solução de controvérsias da mesma natureza, o número atingirá mais de 70 instituições em funcionamento. Os resultados da pesquisa realizada pelo PICT, dentre os quais quadro sinóptico que inclui órgãos já extintos e outros propostos, encontram-se disponíveis em $<$ www.pict-pcti.org $>$. A pesquisa realizada pelo PICT indica que, no século XX, em especial na sua segunda metade, ocorreu não apenas uma mudança quantitativa nos mecanismos de solução de
} 
a heterotutela institucionalizadas. Ao contrário do que ocorre na autotutela, em que há uma relação direta entre as partes e nada impede que uma imponha sua decisão à outra, nas demais, a declaração da existência ou inexistência do direito controverso faz-se imprescindível $^{18}$. Deste modo, a identificação do direito a ser aplicado torna-se relevante.

De acordo com H. L. A. HART (1997:94), as normas podem ser primárias ou secundárias. As normas primárias seriam aquelas que estabelecem obrigações diretamente sobre os indivíduos, de modo a obrigá-los ou proibi-los de fazerem algo; as secundárias, por sua vez, seriam as "normas sobre normas", que visam a criar, modificar ou extinguir as normas primárias e podem ser classificadas em i. de reconhecimento, ii. de mudança e iii. de adjudicação (HART:1997, 79).

As normas de reconhecimento são aquelas que determinam a validade das normas pertencentes a um ordenamento em específico e, por isso, acabam com a incerteza do sistema pré-jurídico (HART:1997, 94). As normas de mudança “empower an individual or body of persons to introduce new primary rules for the conduct of the life of the group, or of some class within it, and to eliminate old rules" e, assim, tornam o sistema dinâmico (HART:1997,96). Por fim, as terceiras, que eliminam a ineficiência do sistema, são aquelas que autorizam os indivíduos "to make authoritative determinations of the question whether, on a particular occasion, a primary rule has been broken" (HART:1997,96).

A introdução de normas secundárias em um conjunto de normas primárias significa a passagem do mundo pré-jurídico para o jurídico, ao conferir-lhe certeza, dinamicidade e eficiência (HART:1997,04). Tal concepção encontra-se na base na definição de juridicização de K. W. AвBOTT et al (2000:401), que a concebe enquanto institucionalização caracterizada por três fatores: obrigação, especificidade e delegação.

O primeiro, obrigação, indica que os Estados e outros atores internacionais encontram-se "legally bound by a rule or commitment in the sense that their behavior thereunder is subject to scrutiny under the general rules, procedures, and discourse of international law, and often of domestic law itself' (АВВот et al:2000,401). O segundo,

controvérsias nas relações internacionais, mas também uma mudança qualitativa, dado o grande número de órgãos judiciais estabelecidos, seja de competência ratione materiae geral seja especial. C. P. R. ROMANO (1998-1999:711) chega a utilizar até mesmo a expressão "judiciário internacional" para se referir aos "judicial bodies that have been created to administer international justice, without implying the existence of any degree of coordination among them".

${ }^{18}$ V., por exemplo, A. C. CINTRA, A. P. GRINOVER e C. R. DINAMARCO (1999:22) e A. Z. CASTILLO (1970). 
especificidade, indica que as regras definem, de forma não ambígua, a conduta permitida, obrigada ou proibida (АВВОт et al:2000,412). Por fim, o terceiro fator, delegação, refere-se à autorização para que Terceiros possam implementar, interpretar e aplicar regras, bem como resolver as disputas que lhe são submetidas e, ainda, produzir novas regras(АВBОт et al:2000,415).

A identificação da norma de reconhecimento não pode ser estabelecida de modo imediato. Isso ocorre porque sua natureza é diferenciada em relação às demais: enquanto estas podem ter sua existência verificada, a norma de reconhecimento "exists only as a complex, but normally concordant, practice of the courts, officials, and private persons in identifying the law by reference to certain criteria"(HART:1997,110). Assim,sua existência é uma questão de fato e ocorre apenas nos ordenamentos jurídicos perfeitos, ou seja, com o mais alto grau de juridicização - hoje, atribuído ao Estado.

Constata-se, ainda, que cada uma das dimensões citadas compreende gradações próprias que não se esgotam numa dicotomia rígida e variam de forma independente uma da outra. Em conseqüência, "the concept of legalization encompasses a multidimensional continuum, ranging from the 'ideal type' of legalization, where all three properties are maximized; (...) to the complete absence of legalization, another ideal type" (АВвотт et $a l: 2000,401)$. As combinações possíveis entre os três fatores referidos foram organizadas no quadro abaixo.

O processo de juridicização pode ser definido, portanto, como o que conduz ao estabelecimento de um ordenamento jurídico por meio da introdução de normas secundárias e afirmação de normas primárias.

Nas relações internacionais, o grau mínimo de juridicização é aquele que os níveis de obrigação, especificidade e delegação são mínimos (v. quadro abaixo) - é o cenário com que trabalham os teóricos realistas e neo-realistas, que predominaram dentre os condutores das relações internacionais ao longo de todo o século XX: não existe o direito internacional e qualquer tipo regra prevalecerá apenas na medida em que responda aos interesses das maiores potências ${ }^{19}$. O grau máximo, por sua vez, seria o próprio Estado: Terceiro super partes, que tem competência para criar, modificar e eliminar normas

\footnotetext{
${ }^{19}$ V., por exemplo, H. J. Morgenthau (2003) e R. Aron (2002). S. L. LAMY (2001) procurar apresentar de forma sistematizada esta literatura.
} 
(jurisdição legislativa), executar as normas criadas (jurisdição executiva) e decidir os conflitos que sobre elas eventualmente surjam (jurisdição judicial) ${ }^{20}$.

\begin{tabular}{|c|c|c|c|c|}
\hline \multicolumn{2}{|c|}{ Nível } & Obrigação & Especificidade & Delegação \\
\hline \multirow[t]{7}{*}{ Máximo } & I & Alto & Alto & Alto \\
\hline & II & Alto & Baixo & Alto \\
\hline & III & Alto & Alto & Baixo \\
\hline & IV & Baixo & Alto & Alto (moderado) \\
\hline & V & Alto & Baixo & Baixo \\
\hline & VI & Baixo & Baixo & Alto (moderado) \\
\hline & VII & Baixo & Alto & Baixo \\
\hline Mínimo & VIII & Baixo & Baixo & Baixo \\
\hline
\end{tabular}

Quadro 1: Possíveis formas de juridicização das relações internacionais

Fonte: Аввотт et al (2000:406).

Isso ocorre porque, na comunidade política organizada enquanto Estado, existe uma concepção vertical de jurisdição, que permite o estabelecimento do Terceiro super partes, como afirma R. A. FALK (1958-1959) ${ }^{21}$. Em âmbito internacional, por outro lado, devido à prevalência da soberania enquanto elemento do Estado $^{22}$, partilha-se uma concepção horizontal de jurisdição, na qual se distribui competência entre centros formalmente iguais de autoridade legal ${ }^{23}$.

A soberania, contudo, passou por transformação em seu conceito ${ }^{24}$, de modo que, hoje, não é mais reconhecida enquanto suprema potestas superiorem non recognoscens, como o fora pelos Tratados de Vestfália e pelo Congresso de Viena de 1815.

\footnotetext{
${ }^{20}$ As definições de jurisdição são devidas a M. AKEHURST (1974).

21 Tal concepção corresponderia à hierarquia entre o Terceiro e aqueles que lhe estão sujeitos. Em sua concepção não se procede, contudo, à análise da fonte da autoridade desse Terceiro, como ocorre, por exemplo, em M. OAKESHOTT (s/a) e H. KELSEN (2000; 1998).

${ }^{22}$ A soberania é elemento atribuído ao Governo, um dos elementos constitutivos do Estado, cf. a Convenção de Montevidéu sobre Direitos e Deveres dos Estados.

${ }^{23}$ Lembre-se, por exemplo, o artigo 2.1. da Carta das Nações Unidas que, expressamente, reconhece a igualdade soberana de todos os seus membros.

${ }^{24}$ V. desenvolvimento do tema em, por exemplo, L.FERRAJOLI (2002).
} 
Aliada a tal transformação, houve, na segunda metade do século XX, aumento significativo dos instrumentos que formalizam os mecanismos pacíficos de solução de controvérsias, dentre os quais, em especial, os mecanismos judiciais e quasi-judiciais ${ }^{25}$.

Deste modo, não se pode negar que houve uma alteração do nível de juridicização das relações internacionais em direção a grau maior de juridicização. Como conseqüência, nestes casos, a possibilidade de os Estados intervirem na decisão das disputas para se favorecerem é restringida, de modo que as decisões passam a serem proferidas de acordo com o Direito e não com a vontade dos Estados, ou do Estado mais forte envolvido (SMITH :2000,143).

\subsection{A delegação de autoridade}

De acordo com R. O. Keohane, A. Moravcsik, A.-M. Slaughter (2000:458), a delegação de autoridade tem três dimensões fundamentais: acesso, independência e efeitos da decisão ${ }^{26}$. A primeira, acesso, refere-se à facilidade com que as partes podem influenciar a agenda do mecanismo de solução de controvérsias, ou seja, quem tem acesso e a qual custo. A segunda, independência, indica o nível em que a decisão sobre a disputa pode ser prolatada de modo imparcial em relação aos interesses dos Estados envolvidos. Por fim, a terceira, efeitos da decisão, demonstra o quanto as decisões dos procedimentos de solução de controvérsia podem ser implementadas sem a intervenção direta dos Estados envolvidos.

\subsubsection{Acesso ao mecanismo}

O primeiro fator relacionado à delegação de autoridade consiste na regulamentação do acesso ao mecanismo de resolução de disputas. O acesso "measures the range of social and political actors who have legal standing to submit a dispute to be

\footnotetext{
${ }^{25}$ G. F. S. SOARES (2002), por exemplo, refere-se à supranacionalidade como transferência de competência dos Estados para os órgãos comunitários.

${ }^{26}$ Os termos utilizados são, respectivamente: access, independence e embeddedness. V. tb. E. C. G. SILVA (2004).
} 
resolved: from a political perspective, access measures the range of those who can set the agenda" (Keohane; MoravcsiK; Slaughter:2000,458). Este aspecto é importante, porque os mecanismos de solução de controvérsias são órgãos passivos, cujos integrantes não têm capacidade para iniciar seus próprios procedimentos.

De acordo com o direito internacional clássico, apenas os Estados eram considerados sujeitos de direito internacional e tinham, então, capacidade de participar de procedimentos perante cortes. O único meio pelo qual o indivíduo poderia se aproximar destas seria pelo exercício de proteção diplomática pelo Estado do qual é nacional. A primeira decisão da CPJI que cuidou do assunto foi a referente ao caso PanevezysSaldutiskis Railway. Posteriormente, a proteção diplomática foi reiterada na decisão do caso The Mavrommatis Palestine Concessions:

"It is an elementary principle of international law that a State is entitled to protect its subjects, when injured by acts contrary to international law committed by another State, from whom they have been unable to obtain satisfaction through the ordinary channels. By taking up the case of one of its subjects and by resorting to diplomatic action or international judicial proceedings on his behalf, a State is in reality asserting its own rights - its right to ensure, in the person of its subjects, respect for the rules of international law. The question, therefore, whether the present dispute originates in an injury to a private interest, which in point of fact is the case in many international disputes, is irrelevant from this standpoint. Once a State has taken up a case on behalf of one of its subjects before an international tribunal, in the eyes of the latter the State is sole claimant".

Tal princípio foi aperfeiçoado com a decisão do caso Nottebohm, apresentado perante a CIJ, entre Liechtenstein e Guatemala. Neste caso, foi estabelecido o princípio do vínculo efetivo, segundo o qual para que um Estado possa exercer sua proteção diplomática sobre um indivíduo, faz-se necessário que tenha vínculos efetivos com ele, seja por tradição, interesses, atividades, laços familiares ou outros fatores ${ }^{27}$.

Salvo algumas exceções, como o sistema interamericano de proteção dos direitos humanos, a regra geral ainda é de que os indivíduos, para terem acesso a mecanismos de solução de controvérsias, precisam contar com a representação formal do Estado de que são nacionais ou com que têm vínculos efetivos. Conseqüentemente, as

\footnotetext{
${ }^{27}$ Sobre esta decisão, v. C. FORCESE (2005).
} 
reclamações de indivíduos contra seus próprios Estados tornam-se, na maior parte dos casos, impossíveis.

Com relação à participação de pessoas jurídicas, por sua vez, a decisão da CIJ no caso Barcelona Traction, Light and Power Company, Limited estabeleceu a regra de que somente o Estado em que foi incorporada a pessoa jurídica pode exercer a proteção diplomática sobre tal entidade. Ao seguir este princípio de forma rigorosa, o Centro Internacional para a Solução de Disputas sobre Investimentos (ICSID) permitiu que, no caso $N .^{\circ}$ ARB/02/18 ("Tokios Tokeles") ${ }^{28}$, uma empresa ucraniana, acionária da Tokios Tokeles, acionasse seu próprio governo nos procedimentos perante o Centro.

Além de indivíduos e Estados, há de se citar, ainda, a participação de organizações e organismos internacionais, como agências da ONU e outros. O artigo 96 da Carta da ONU, por exemplo, prevê que a Assembléia Geral ou o Conselho de Segurança podem solicitar, a qualquer momento uma opinião consultiva à $\mathrm{CIJ}^{29}$. De acordo com o segundo parágrafo do referido artigo, qualquer outro órgão da ONU ou agência especializada também o pode fazer, mas, para tanto, precisa da autorização da Assembléia Geral.

Ressalte-se, contudo, que a tendência de sua participação direta ou indireta em mecanismos específicos tem sido verificada. Isso ocorre especialmente em algumas cortes de direitos humanos ${ }^{30}$ e em determinados acordos de investimentos ${ }^{31}$. A participação de indivíduos, ainda que de forma não direta, é possível também no âmbito do Mercosul. Tal participação foi regulamentada, primeiramente, pelo Protocolo de Brasília e, hoje, pelo Protocolo de Olivos. De acordo com D. VentuRA (2003:249), ainda que a participação de indivíduos seja mediata, ela não se confunde com a proteção diplomática, visto que não há a exigência do esgotamento dos recursos internos antes de se recorrer às instituições comunitárias.

A participação formal de atores não estatais, de modo geral, costuma ser prevista apenas para procedimentos de arbitragem e meios judiciais. Nos demais

\footnotetext{
${ }^{28}$ A autora agradece a Thiago Pedroso pela indicação do caso.

${ }^{29}$ A competência consultiva da CIJ é regulada pelos artigos 65 a 68 de seu Estatuto.

${ }^{30}$ Sobre a participação de indivíduos em casos que envolvem a proteção dos direitos humanos, v. A. A. C. TRINDADE (1998).

${ }^{31}$ A respeito do tema, v. UNCTAD (2003).
} 
(negociação, inquérito, bons ofícios, mediação e conciliação), como regra, a participação fica restrita à figura do Estado.

Verifica-se que, em muitos procedimentos sem previsão de participação formal de indivíduos, estes tentam se manifestar por meio da apresentação de documentos considerados amicus curiae. A prática com relação aos amicus curiae, contudo, não é pacífica $^{32}$.

Outro ponto a ser notado neste aspecto, refere-se aos custos necessários para condução de uma disputa ao longo de todas suas fases. Isto porque o volume de recursos necessários para patrocínio de uma causa pode se transformar em obstáculo, caso uma das partes não possa dispendê-los para tal fim. Deste modo, este fator pode ser utilizado como determinante do perfil daqueles que utilizarão um determinado sistema de solução de controvérsias.

Por fim, há de se citar a automaticidade dos procedimentos que conduzem à formalização de uma disputa perante um determinado sistema de solução de controvérsias. Neste sentido, uma regra que implica na concordância do Estado demandado para iniciação da disputa pode se tornar obstáculo para a própria disputa. No caso da CIJ, por exemplo, há duas possibilidades: ou aceita-se a cláusula voluntária de jurisdição obrigatória ${ }^{33}$ ou aceitase a jurisdição da Corte por meio de um acordo específico ${ }^{34}$. Neste exemplo, o procedimento refere-se ao próprio reconhecimento da jurisdição da corte sobre a questão. Há casos, contudo, em que, mesmo após tal reconhecimento, é necessária a observância de determinados requisitos antes que se formalize uma disputa - este é o caso do sistema de solução de controvérsias da OMC, a ser analisado no próximo capítulo.

\subsubsection{Independência}

\footnotetext{
32 É possível encontrar discussão mais aprofundada sobre o tema em D. SHELTON (1994).

${ }^{33} \mathrm{O}$ artigo 36.2 do Estatuto da CIJ estatui expressamente: "The states parties to the present Statute may at any time declare that they recognize as compulsory ipso facto and without special agreement, in relation to any other state accepting the same obligation, the jurisdiction of the Court in all legal disputes".

${ }^{34}$ Observa-se, contudo, que, no caso Military and Paramilitary Activities in and against Nicaragua, a Corte conheceu a disputa, apesar de os EUA não terem nem aceitado a referida cláusula nem entrado em acordo específico.
} 
A variável independência, que indica o nível em que os Terceiros envolvidos são capazes de prolatar uma decisão independentemente dos governos envolvidos, compreende três dimensões que, por sua vez, referem-se a restrições institucionais: modo de seleção e mandato dos julgadores (independência subjetiva), amplitude da jurisdição (independência decisória) e recursos disponíveis (independência financeira).

No que se refere à independência subjetiva, verifica-se que, com exceção dos tribunais permanentes e da negociação (em que não há a participação de Terceiros), em todos os demais mecanismos de solução de controvérsias (inquérito, bons ofícios, mediação, conciliação, arbitragem e tribunais ad hoc), a escolha dos intervenientes é realizada ad hoc. Na maior parte das vezes, com a anuência dos Estados envolvidos.

$\mathrm{Na}$ arbitragem, o procedimento de escolha dos árbitros depende do compromisso de arbitragem (que pode ser denominado de forma diversa) estabelecido entre os Estados envolvidos - neste caso, as regras de direito internacional exercem função apenas supletiva (Dihn, DAILliER, Pellet:2003,887). O próprio compromisso de arbitragem pode ser prévio ou posterior ao surgimento do conflito. No caso do Mercosul, por exemplo, cada Estado envolvido em uma controvérsia designa um árbitro titular e um suplente da lista prévia, no prazo de 15 dias após a comunicação à Secretaria da decisão de se recorrer à arbitragem (Artigo 10.2 do Protocolo de Olivos ). O árbitro presidente, por sua vez, deve ser designado de comum acordo pelos Estados em litígio, no mesmo prazo caso não cheguem a acordo, a própria Secretaria Administrativa do Mercosul procederá a sorteio mediante pedido específico (artigo 10.3 do Protocolo de Olivos).

Nos tribunais permanentes, os juízes são escolhidos dentre uma lista de indicados pelos Estados que são parte do órgão e têm mandato por prazo determinado e renovável na maior parte das vezes, renovável. No caso da CIJ, por exemplo, de acordo com o artigo 2. ${ }^{\circ}$ de seu Estatuto, os magistrados escolhidos não são representantes de seus Estados e devem ser escolhidos dentre as pessoas que gozem da mais alta reputação em seus respectivos países, das mais altas funções judiciárias ou que sejam jurisconsultos de reconhecida competência em matéria de direito internacional. Os juízes da CIJ são escolhidos, conjuntamente, pela Assembléia Geral e pelo Conselho de Segurança da ONU a partir da lista do Tribunal Permanente de Arbitragem (TPA) - artigo 4.1 do Estatuto da CIJ. Todos os escolhidos recebem o mandato por 9 anos, com possibilidade de renovação (artigo 13.1 do Estatuto da CIJ). Ainda de acordo com o Estatuto (artigo 18), nenhum 
membro da Corte pode ser despedido, salvo se houver consenso dentre os demais membros sobre ele não mais preencher os requisitos para exercer o cargo.

Ressalte-se que, apesar das diferenças no modo de seleção, tanto na arbitragem quanto nos tribunais, a possibilidade de que o julgador tenha sido parcial em sua decisão é causa de nulidade da decisão ou do laudo respectivos.

No que se refere à independência decisória, que indica a amplitude do mandato concedido ao órgão de solução de controvérsias, tanto as normas que podem ser utilizadas quanto as regras de interpretação aplicáveis devem ser analisadas nos procedimentos em que algum tipo de posição é apresentada - ou seja, inquérito, mediação, conciliação, arbitragem e meios judiciais.

Salvo disposição específica, de acordo o artigo 38 do Estatuto da CIJ, as fontes de direito internacional são:

a) as convenções internacionais, quer gerais, quer especiais, que estabeleçam regras expressamente reconhecidas pelos Estados litigantes;

b) o costume internacional, como prova de uma prática geral aceita como sendo direito;

c) os princípios gerais de direito, reconhecidos pelas nações civilizadas;

d) sob a ressalva da disposição do Artigo 59, as decisões judiciárias e a doutrina dos juristas mais qualificados das diferentes nações, como meio auxiliar para a determinação das regras de direito ${ }^{35}$.

No caso da CIJ e do Mercosul, há, ainda, menção expressa à possibilidade de a questão ser decidida ex aequo et bono, se as partes com isto concordarem ${ }^{36}$.

Deve-se ressaltar, também, que os inquéritos têm como escopo o esclarecimento de fatos, de modo que não há pronunciamento acerca das questões de direito. Na mediação e na conciliação, por sua vez, não há regras específicas a regerem a proposta apresentada pelos Terceiros. Por fim, na arbitragem, as fontes a serem utilizadas pelos árbitros serão definidas no compromisso de arbitragem pelos Estados envolvidos -

\footnotetext{
${ }^{35}$ Tradução para o português de V. M. RANGEL (2000:79).

${ }^{36}$ Respectivamente, artigo 38.2 do Estatuto da CIJ e artigo 34.2 do Protocolo de Olivos.
} 
no silêncio deste, o árbitro deve aplicar automaticamente o direito internacional positivo (Dihn, DAILLIER, PELLET:2003,895).

Com relação à outra dimensão da independência decisória, vale lembrar que, em seus comentários sobre a Carta da ONU, H. KELSEN (1951) chegou a afirmar que se os Estados tivessem idéia da amplitude da liberdade do julgador sobre uma causa, eles nunca submeteriam suas controvérsias a uma decisão jurisdicional ${ }^{37}$. As regras de interpretação, portanto, auxiliam a definir o conjunto de regras e procedimentos a serem utilizados pelos julgadores na motivação de sua decisão. Reitera-se que, na negociação, nos bons ofícios e no inquérito, não há pronunciamento sobre questões de direito. Além disso, na mediação e na conciliação, não se faz necessária a motivação da proposta apresentada. Por fim, na arbitragem, as regras podem ser definidas pelo compromisso de arbitragem. As cortes, em geral, detém competência para interpretação de tratados, como é o caso, por exemplo, da CIJ (artigo 36.1 do Estatuto). ${ }^{38}$

\footnotetext{
${ }^{37}$ H. KELSEN (1951:XV) explica: "The choice of interpretation as a law making act is determined by political motives. It is not the logically 'true', it is the politically preferable meaning of the interpreted norm which becomes binding".
}

${ }^{38}$ Hoje, a principal fonte para regras de interpretação de tratados é a Convenção de Viena sobre Direito dos Tratados, cujos artigos 31 a 33 tratam especificamente de tal questão. A Convenção, cujas negociações perduraram por mais de 20 anos, foi um marco na codificação do costume do direito internacional. Para relato das sessões de negociação sobre a celebração de convenção sobre direito dos tratados, v. G. E. N. SILVA (1971). No que se refere às regras de interpretação nela constantes, a própria CIJ já declarou que os princípios refletidos nos artigos 31 e 32 da Convenção de Viena sobre Direito dos Tratados podem ser considerados codificação do direito costumeiro internacional, ou seja, seriam vinculantes ainda que os Estados envolvidos não tenham ratificado a referida Convenção, cf. decisão da CIJ no caso Arbitral Award of 31 July 1989. De acordo com o artigo 31 da Convenção de Viena sobre Direito dos Tratados, os tratados devem ser interpretados de boa-fé, segundo o sentido comum de seus termos em seu contexto e à luz de seu objeto e finalidade. De acordo com o parágrafo 4 do referido artigo, somente serão admitidos sentidos especiais, quando houver menção expressa das partes. Para os fins de interpretação de um tratado, o contexto compreende, além do texto, seu preâmbulo e anexos: a) qualquer acordo relativo ao tratado e feito entre todas as partes por ocasião da conclusão do tratado; b) qualquer instrumento estabelecido por uma ou várias partes por ocasião da conclusão do tratado e aceito pelas outras partes como instrumento relativo ao tratado. Devese, ainda, levar em consideração, juntamente com o contexto: a) qualquer acordo posterior entre as partes relativo à interpretação do tratado ou à aplicação de suas disposições; b) qualquer prática seguida posteriormente na aplicação do tratado pela qual se estabeleça o acordo das partes relativo à sua interpretação; e c) qualquer regra pertinente de direito internacional aplicável às relações entre as partes. Sobre declarações interpretativas unilaterais, v. R. SAPIENZA (1999). O artigo 32 da Convenção de Viena sobre Direito dos Tratados, por sua vez, define os meios suplementares de interpretação aos quais se podem recorrer, caso o sentido resultante da aplicação do artigo 31 seja ambíguo ou obscuro (alínea $a$ ) ou conduza a um resultado que é manifestamente absurdo ou desarrazoado (alínea $b$ ). De acordo com o referido artigo, os meios suplementares de interpretação são, em particular, os trabalhos preparatórios do tratado e as circunstâncias de sua conclusão. A análise dos trabalhos preparatórios das Convenções constituíam prática comum mesmo antes da convenção, v. H. LAUTERPACHT (1934). Por fim, o artigo 33 cuida da interpretação de tratados autenticados em duas ou mais línguas. De acordo com seu parágrafo 1. ${ }^{\circ}$, quando um tratado for autenticado em duas ou mais línguas, seu texto faz igualmente fé em cada uma delas - salvo disposição expressa em contrário. Presume-se, de acordo com o parágrafo $3 .^{\circ}$, que os termos do tratado têm o mesmo sentido nos diversos textos autênticos. Nos casos em que a comparação dos textos autênticos revela uma 
Por fim, a independência financeira "refers to the ability of judges to process their caseloads promptly and effectively" e de "develop a factual record independent of the state litigants before them and to publicize their decisions"(KEOHANE; MORAVCSIK; SLAUGHTER:2000,462). Este aspecto é especialmente importante para as cortes de direitos humanos, que procuram disseminar informação e mobilizar apoio político para suas decisões, que encontram grande resistência nos Estados.

De modo geral, no caso do inquérito, dos bons ofícios, da mediação e da conciliação, as despesas havidas no processo devem ser suportadas diretamente pelos Estados litigantes. No caso da arbitragem, elas podem ser suportadas tanto diretamente pelos Estados envolvidos quanto pelos órgãos em cujo âmbito se dão.

No Mercosul, por exemplo, de acordo com o artigo 36 do Protocolo de Olivos, os gastos e honorários ocasionados pela atividade dos árbitros serão custeados pelo país que os designe e os gastos e honorários do Presidente do Tribunal Arbitral Ad Hoc serão custeados em partes iguais pelos Estados partes na controvérsia, a menos que o Tribunal decida distribuí-los em proporção distinta. Ainda de acordo com o referido artigo, tais gastos podem ser pagos por intermédio da Secretaria Administrativa do Mercosul, que administra um Fundo Especial criado pelos Estados Partes. Percebe-se, portanto, que os recursos destinados ao funcionamento dos tribunais arbitrais são concedidos apenas para as despesas específicas de cada caso, o que ocorre mesmo com o TPR que, embora seja permanente, reúne-se apenas quando convocado, de acordo com o artigo 19 do Protocolo de Olivos.

No caso da CIJ, de acordo com o artigo 33 de seu Estatuto, todas as despesas da Corte devem ser suportadas pela ONU tal como decidido pela Assembléia Geral. No que se refere à remuneração dos juízes, o artigo 32 de seu Estatuto determina que cada membro da Corte deve receber um salário anual, que será determinado pela Assembléia Geral, mas não pode ser reduzido ao longo de seu mandato.

diferença de sentido que a aplicação dos arts. 31 e 32 não elimina, contudo, adotar-se-á o sentido que, tendo em conta o objeto e a finalidade do tratado, melhor concilie esses textos (artigo 33.4). Para maiores informações sobre a interpretação de tratados com línguas oficiais, v. C. B. KUNER (1991) e, no caso especial da OMC, v. E. M. CARVALHO(2005). Além dessas regras, há ainda outras que foram criadas posteriormente à celebração da Convenção de Viena sobre Direito dos Tratados. Dentre elas, ressalta-se a interpretação evolutiva, gerada no âmbito da CIJ. Para maiores informações acerca da interpretação evolutiva, v. J. PAUWELYN (2002). 


\subsubsection{Efeitos da decisão}

Por fim, o último dos fatores relacionados à delegação de autoridade diz respeito aos efeitos da decisão no ordenamento dos Estados envolvidos. Verifica-se que "the political significance of delegating authority over dispute resolution therefore depends in part on the degree of control exercised by individual governments over the legal promulgation and implementation of judgments (KEOHANE; MORAVCSIK; SlaughtER:2000,466). Isso porque, embora todo Estado seja obrigado a respeitar as decisões de cortes e arbitragens internacionais, não há previsão de que elas tenham efeito direto sobre os ordenamentos dos envolvidos, nem mecanismos que assegurem sua implementação. Esta depende, portanto, da ação do Estado.

Este fator refere-se à classificação supracitada entre órgãos inter-estatais e supranacionais. Apesar de a discussão ser ampla, contudo, as experiências supranacionais são poucas, pois existem apenas nos casos em que há transferência de competências dos Estados para os órgãos comunitários e o reconhecimento do princípio da supremacia do direito comunitário ${ }^{39}$. A primeira corte supranacional foi o Tribunal de Justiça das Comunidades Européias, que foi fundamental para o desenvolvimento do princípio da supremacia do direito comunitário em seu âmbito.

As demais Cortes não têm tais características, pois a função de avançar com o processo de integração é responsabilidade dos próprios Estados partes. É o caso, por exemplo, do Mercosul, em que os ordenamentos nacionais de seus Estados partes dispõem diversamente sobre a supranacionalidade dos órgãos comunitários: enquanto a legislação brasileira não aceita um órgão supranacional, a Constituição argentina expressamente prevê tal possibilidade.

Por fim, com relação aos demais procedimentos de solução de controvérsias, vale lembra que: nos bons ofícios, não há decisão apresentada pelo Terceiro que os oferece; na mediação e na conciliação, são apresentadas apenas sugestões; no inquérito, há verificação apenas de fatos e não de avaliações de direito envolvido; e, na negociação, pode haver ou não resultado, que seguirá as regras sobre tratados e acordos.

\footnotetext{
${ }^{39}$ Sobre tal princípio no âmbito das Comunidades Européis, v. P. B. CASELlA (2002:309).
} 


\subsection{Delegação de autoridade nos procedimentos de solução de controvérsias no direito internacional}

\subsubsection{Procedimentos de Solução de controvérsias no direito internacional}

O primeiro marco no processo de regulamentação autônoma do dever de recorrer a meios pacíficos de solução de controvérsias foi a celebração das Convenções para a Solução Pacífica de Controvérsias de 1899 e 1907, nas Conferências de Paz da Haia $^{40}$. Por meio dessas Convenções, os Estados partes comprometeram-se a envidar todos seus esforços na resolução pacífica de controvérsias, de modo a evitar o recurso à força em sua relação (artigo $1^{\text {o }}$ da Convenção de 1907), e estabeleceram o TPA, ao qual poderiam recorrer para tal fim.

O passo seguinte no processo de reconhecimento do dever de solução pacífica de controvérsias deu-se, após a Primeira Guerra Mundial, com a criação da Liga das Nações (LDN), em 1918 ${ }^{41}$. O Pacto da LDN expressamente previa, em seu artigo 12.1, que todos os Membros da LDN concordavam em que, se entre eles surgisse uma controvérsia suscetível de produzir uma ruptura de suas relações, submeteriam o caso a um dos mecanismos seguintes: arbitragem, solução judiciária ou apresentação ao Conselho da LDN. Eles ainda se comprometiam a não recorrer à guerra de modo nenhum, antes da expiração do prazo de três meses após a decisão arbitral ou judiciária, ou o relatório do Conselho.

A exclusão da guerra como instrumento de política nacional reconhecido pelo direito internacional, no entanto, somente ocorreu com o Pacto Briand-Kellong, em 1928, que chegou a ser assinado por 62 países $^{42}$. O artigo $1^{\circ}$ do Pacto declara que os signatários "condemn recourse to war for the solution of international controversies, and renounce it, as an instrument of national policy in their relations with one another". A partir de então, a

\footnotetext{
40 Tais Convenções e demais documentos de trabalho do TPA encontram-se disponíveis em $<$ http://www.pca-cpa.org/>. Acesso em: 21 jan. 2007.

${ }^{41}$ Sobre a LDN, v. L. F. L. OpPenheim (1919), J. C. L. A. S. LimA (1927) e A. Anghie (2002). O Pacto da da LDN encontra-se disponível em <http://www.worldcourts.com/pcij/eng/documents.htm>. Acesso em: 21 jan. 2007.

${ }^{42}$ Conteúdo disponível em < http://www.yale.edu/lawweb/avalon/imt/kbpact.htm>. Acesso em: 25 jan. 2005.
} 
guerra passou a ser aceita apenas como meio de autodefesa, o que foi consolidado, posteriormente, no âmbito da $\mathrm{ONU}^{43}$.

Nesse ínterim, em 1920, após dois anos de negociação, a Assembléia Geral da LDN resolve pela criação da Corte Permanente de Justiça Internacional (CPJI) ${ }^{44}$, cujo Estatuto entrou em vigor em setembro de 1921. A CPJI funcionou até 1946, quando foi substituída pela Corte Internacional de Justiça (CIJ) ${ }^{45}$. A CIJ, por sua vez, foi estabelecida pela Carta da ONU, e seu Estatuto consiste no texto revisado do Estatuto da CPJI.

De acordo com o artigo 2.3 da Carta da ONU, ao contrário do que ocorria com o Pacto da LDN, os Membros da Organização comprometem-se a resolver suas controvérsias internacionais por meios pacíficos, de modo que não sejam ameaçadas a paz, a segurança e a justiça internacionais. O parágrafo seguinte ainda reafirma que todos os Membros devem evitar, em suas relações internacionais, a ameaça ou o uso da força contra a integridade territorial ou a independência política de qualquer Estado, ou qualquer outra ação incompatível com os propósitos das Nações Unidas.

Diante de tal dever, o artigo 33 da Carta indica os procedimentos aos quais as partes podem recorrer para resolverem suas controvérsias, quais sejam: negociação, inquérito, mediação, conciliação, arbitragem, solução judicial, recurso a entidades ou acordos regionais, ou a qualquer outro meio pacífico à sua escolha.

Não existe, contudo, uma seqüência que, obrigatoriamente, deva ser seguida entre os diversos mecanismos citados. A única tentativa de estabelecer uma ordem necessária foi o Protocolo de 02 de outubro de 1924, iniciativa da Assembléia Geral da LDN que foi abandonada por número insuficiente de ratificações (DIHN, DAILLIER, Pellet:2003). Esta liberdade de escolha também é reconhecida pela Declaração de Manila sobre a Solução Pacífica de Controvérsias Internacionais e pela CIJ, que, em diversas

\footnotetext{
${ }^{43}$ Por tal razão que a guerra preventiva tem sido objeto de muita discussão na ONU, em especial, após a invasão do Iraque pelos EUA. Acerca do debate sobre o papel da ONU neste contexto e a especificação de guerra preventiva, v. W. C. BRAdFord (2004), C. Pierson (2004), M. SAPIRO (2003), R. A. FALK (2003) e O. CORTEN (2005).

44 A respeito da CPJI, v. J. B. ScOtt (1921), A. Hammarskjöld (1924) e F. Phillimore (1922). A resolução de criação da CPJI é a seguinte: THE AMERICAN JOURNAL OF INTERNATIONAL LAW (1923). A lista de assinaturas e ratificações, por sua vez, encontra-se disponível em: THE AMERICAN JOURNAL OF INTERNATIONAL LAW (1926).

${ }^{45}$ A respeito deste processo, v. M. HudSON (1957).
} 
decisões $^{46}$, reconheceu não haver um nexo lógico em sua utilização, além da vontade dos Estados envolvidos. Assim, para que se estabeleça uma seqüência obrigatória, faz-se necessário que os próprios Estados envolvidos tenham convenção específica nesse sentido.

A negociação é o mais tradicional dos meios citados, pois consiste no contato direto entre os Estados em controvérsia. Na negociação, os próprios envolvidos estabelecem conversações no sentido de chegar a um acordo sobre sua disputa. Em geral, as negociações têm caráter confidencial e informal ${ }^{47}$, não há participação de terceiros e a publicação de seus resultados depende da vontade das partes. Elas podem ser apenas entre dois Estados (negociações bilaterais), entre Estados de região específica (negociações regionais) ou abertas a todos os que preencham determinados requisitos (negociações multilaterais). As negociações também podem ser denominadas "consultas", "troca de opiniões" ou outras expressões similares. A observância do que for acordado segue as regras de direito internacional geral, salvo se houver previsão em contrário ${ }^{48}$.

O mecanismo seguinte citado pelo artigo 33 da Carta da ONU é o inquérito. De acordo com o artigo $7^{\circ}$ da Convenção da Haia de 1907, o inquérito pode ser utilizado nos casos em que há discordância sobre questões de fato. Nesse caso, estabelece-se uma comissão para conduzir o inquérito acerca da questão controversa, de modo a facilitar a solução da disputa por meio de uma investigação imparcial que elucide os fatos. Os Estados envolvidos devem concordar sobre os integrantes da Comissão, aos quais concederão, para que possam desempenhar a função para que foram designados, acesso livre às áreas e documentos necessários, além do custeio das despesas havidas. O inquérito é uma figura presente principalmente no cotidiano das organizações internacionais, em que se lhe faculta apresentar sugestões de solução do conflito ${ }^{49}$.

Embora não citados, há também os bons ofícios que são o mecanismo pelo qual um terceiro à disputa visa a aproximar as partes em controvérsia de modo a evitar a deterioração de sua relação e facilitar o acordo entre ambas. Eles podem ser solicitados

\footnotetext{
${ }^{46}$ V., por exemplo, a decisão da CIJ nos seguintes casos: Aegean Sea Continental Shelf; United States Diplomatic and Consular Staff in Tehran; e Military and Paramilitary Activities in and against Nicaragua.

47 Não há registro do que se passa nas reuniões, quais são as declarações realizadas ou propostas apresentadas.

48 Para maiores informações acerca deste mecanismo, v. G. F. S. SoAres (2002:166), N. G. DINH, P. Daillier e A. Pellet (2003:844), M. SHAw (1997:720) e ONU (1991:36).

49 Para maiores informações acerca deste mecanismo, v. G. F. S. SOARES (2002:167); N. G. DINH, P. Daillier e A. Pellet (2003:850), M. SHAw (1997:724) e ONU (1991:51).
} 
pelos Estados envolvidos ou oferecidos pelo próprio terceiro, mas sempre se faz necessária a aceitação dos bons ofícios por todos os envolvidos. Uma característica deste mecanismo é que o interveniente não se manifesta acerca do conteúdo da disputa, pois deve se restringir a facilitar a aproximação das partes em litígio ${ }^{50}$.

Um mecanismo semelhante aos bons ofícios é a mediação. A diferença mais importante é que o terceiro interveniente se manifesta sobre a questão controversa e apresenta sua própria sugestão de acordo, que, em geral, serve como uma base para o início das negociações. Neste caso, também o mediador, que pode se apresentar sponte sua ou ser convidado a tanto por um dos litigantes, deve ser aceito por todos os Estados envolvidos $^{51}$. A proposta do mediador pode ser ou não divulgada, de acordo com a vontade dos Estados.

Um meio mais elaborado de solução de controvérsias é a conciliação. Em geral, a conciliação é realizada por meio de uma comissão cujos membros serão escolhidos pelos Estados em disputa, salvo disposição diversa; em algumas organizações internacionais, por exemplo, a função de escolha dos membros da comissão fica a cargo de seus Secretários Gerais. De acordo com a Revisão do Ato Geral sobre Solução Pacífica de Controvérsias de 1928, o objetivo da comissão de conciliação consiste em elucidar as questões controversas (por meio de coleta de informações) e aproximar as partes de modo a alcançarem um acordo; após esta aproximação, cabe à comissão apresentar sua própria sugestão de acordo (que pode ou não ser acatada pelas partes) e definir um prazo para que as partes decidam a respeito ${ }^{52}$.

Essa possibilidade não atinge o laudo que é emitido pelo procedimento da arbitragem, outro mecanismo de solução pacífica de controvérsias. Para que se recorra à arbitragem $^{53}$, os Estados devem concordar sobre o número e o nome dos árbitros, as regras de procedimento que serão seguidas e o conjunto de normas no qual os árbitros fundamentarão sua decisão. Esta, por sua vez, deverá ser vinculante, visto que os Estados

\footnotetext{
50 Para maiores informações acerca deste mecanismo, v. G. F. S. SoARES (2002:167); N. G. DINH, P. DAillier e A. Pellet (2003:849), M. SHAW (1997:723) e ONU (1991:60).

51 Para maiores informações acerca deste mecanismo, v. G. F. S. SoARES (2002:167); N. G. DINH, P. DAillier e A. Pellet (2003:849); M. SHAW (1997:723) e ONU (1991:68).

52 Para maiores informações acerca deste mecanismo, v. G. F. S. SOARES (2002:168), N. G. DinH, P. DAillier e A. Pellet (2003:852), M. SHAW (1997:726) e ONU (1991:72).

53 Para maiores informações acerca deste mecanismo, v. G. F. S. SoAres (2002:168); N. G. DiNH, P. Daillier e A. Pellet (2003:883); M. Shaw (1997:737) e ONU (1991:82).
} 
envolvidos comprometem-se a respeitá-la, como previsto pelo artigo 37 da Convenção de Haia de 1907.

A primeira formalização deste mecanismo no direito internacional em âmbito multilateral se deu com a instituição do TPA. Em 26 de setembro de 1928, a LDN adotou o Ato Geral de Arbitragem, o qual foi revisto pela Assembléia Geral da ONU em 1949. Em geral, os procedimentos da arbitragem são restritos às partes em litígio e as despesas havidas com os procedimentos devem ser custeadas pelos Estados diretamente. Por fim, há um princípio geral de que não se pode apelar dos laudos arbitrais; exceção é o Protocolo de Olivos para a solução de controvérsias no Mercosul, que não apenas institui o direito de revisão de questões de direito da decisão ${ }^{54}$, como também criou um Tribunal Permanente de Revisão (TPR), com sede em Assunção, no Paraguai.

Por fim, há de se citar os meios judiciais de solução de controvérsias. Neste método, as partes concordam em submeter a controvérsia a uma corte internacional constituída por juízes independentes, os quais decidirão com base no direito internacional $^{55}$. As decisões prolatadas são vinculantes e devem ser respeitadas pelas partes $^{56}$. A primeira Corte em âmbito internacional foi a CPJI, estabelecida pela LDN e, como previamente referido, substituída pela CIJ, criada pela ONU. De fato, a história das Cortes internacionais encontra-se estreitamente ligada à das organizações internacionais (Dinh, DAillier, Pellet:2003,905).

$\mathrm{Na}$ prática, os meios judiciais podem ser tanto permanentes, como, por exemplo, a CIJ, o Tribunal de Justiça das Comunidades Européias (TJCE), o Tribunal Penal Internacional (TPI) e a Corte Interamericana de Direitos Humanos (CIDH), quanto ad hoc, como, por exemplo, os Tribunais de Nuremberg, o Tribunal Penal Internacional para a Ex-Iugoslávia e o Tribunal Penal Internacional para Ruanda ${ }^{57}$. Além disso, as cortes

\footnotetext{
54 De acordo com o artigo 17.3 do referido Protocolo, as decisões com base no ex aequo et bono são inapeláveis.

${ }^{55}$ No caso da CIJ, há a possibilidade de se decidir a questão ex aequo et bono, cf. artigo 38.2 do Estatuto da Corte.

${ }^{56}$ V. G. F. S. SoAres (2002:173); N. G. Dinh, P. DAillier e A. Pellet (2003:905); M. ShaW (1997:745); e ONU (1991:96).

${ }^{57}$ C. P. R. ROMANO (1998-1999), estabelece distinção entre as courts (em português, tribunais) e os tribunals (em português, cortes): os primeiros seriam ad hoc e os últimos, permanentes. Na língua portuguesa, contudo, não é possível manter a mesma distinção, pois não se verifica regularidade na tradução dos nomes oficiais. Com exceção da CIDH e do mecanismo de solução de controvérsias do Mercosul, nenhum outro mecanismo tem o português como língua oficial.
} 
internacionais podem ter jurisdição ratione materiae geral, como a CIJ, ou específica, como o Tribunal do Mar (estabelecido pela Convenção das Nações Unidas sobre o Direito do Mar - UNCLOS, sigla em inglês) e a CIDH.

Outra possibilidade citada pelo artigo 33 da Carta da ONU seria o recurso às organizações regionais e a entidades. Em geral, o Conselho de Segurança e a Assembléia da ONU exercem papel próprio no apaziguamento dos conflitos internacionais, e quaisquer outros mecanismos de solução de organizações regionais envolvem os procedimentos acima descritos (Dinh, DAILliER, Pellet:2003,855).

Embora não haja uma classificação legal dos mecanismos de solução de controvérsias, a doutrina costuma agrupá-los para fins teóricos. Dentre outras, podem ser destacadas as seguintes classificações, i. entre mecanismos inter-estatais e supraestatais/transnacionais, ii. entre mecanismos políticos/diplomáticos e jurídicos; iii. entre mecanismos não-jurisdicionais e jurisdicionais.

A primeira classificação, entre inter-estatais e supra-estatais é utilizada para distinguir, de um lado, os mecanismos que envolvem apenas Estados e cujas decisões estão sujeitas à sua vontade (inter-estatais) e, de outro, aqueles cujas decisões têm aplicabilidade direta no ordenamento jurídico interno do Estado e, em geral, permitem a participação de indivíduos. Esta classificação nasceu a partir do debate acerca dos organismos de integração econômica, em especial, após o estabelecimento das Comunidades Européias ${ }^{58}$. Há de se notar, contudo, que o termo "supra-nacional" é utilizada por R. A. FALK (1959), para se referir aos mecanismos inter-estatais; enquanto R. O. KeOHANE, A. MoravcsiK, A.-M. Slaughter (2000) utiliza o termo "transnacional" para se referir aos mecanismos "supra-nacionais".

A classificação que procura distinguir os mecanismos políticos/diplomáticos dos jurídicos toma, por fundamento, tanto a existência ou não de uma norma jurídica preexistente, como afirma G. F. S. SOARES (2002), quanto a possibilidade de o Estado intervir diretamente no resultado da disputa, como analisa J. M. SMITH (2000).

Por fim, a classificação entre meios jurisdiconais e não-jurisdicionais é utilizada, por exemplo, por N. G. DiNH, P. DAILliER e A. PELLET (2003:841) para distinguir as formas de resolução de controvérsias em que é possível impor uma solução às partes

\footnotetext{
${ }^{58}$ Para maiores informações acerca deste debate, v., por exemplo, G. F. S. SOARES (1998).
} 
(jurisdicionais) e aquelas em que tal solução pode apenas ser proposta sem que haja a obrigatoridade de sua observância (não jurisdiconais).

Sublinhe-se que, de modo geral, tais classificações procuram distinguir sempre entre meios mais e menos formais, em que há maior ou menor possibilidade de intervenção dos Estados envolvidos nos resultados.

\subsubsection{Classificação dos procedimentos em relação ao grau de delegação de autoridade}

A especificação de cada elemento que constitui os três fatores que definem o grau de delegação de autorização de autoridade em um determinado sistema possibilita a classificação dos procedimentos de solução de controvérsias em diferentes níveis do processo de juridicização.

No que se refere a acesso, o recurso a um determinado procedimento pode ser analisado a partir dos seguintes fatores:

1. Legitimidade ativa: verificação dos sujeitos que podem recorrer a um determinado mecanismo, se apenas Estados ou também outros atores;

2. Participação de terceiros: pode ser dividida entre terceiras partes e sujeitos não diretamente interessados (ou seja, possibilidade de apresentação de amicus curiae); neste aspecto, cabe indicar se apenas Estados ou outros sujeitos podem participar dos procedimentos e o nível de formalização do direito de participação;

3. Custos: nível de recursos necessários para patrocínio da causa - quanto mais alto, menor o grau de acesso; e

4. Procedimentos para formalização do início da disputa: neste aspecto, cabe ressaltar quais são os requisitos para que se dê início a determinado procedimento de solução de controvérsias dentro de um sistema;

Com relação ao fator independência, verifica-se que seus três elementos podem ser analisados a partir das variáveis seguintes: 
1. Independência subjetiva: o processo de escolha dos terceiros que irão atuar no procedimento é realizado previamente ao surgimento da disputa ou indicação ad hoc; nível de envolvimento dos Estados partes da controvérsia em tal escolha; e extensão do mandato.

2. Independência decisória: jurisdição ampla ou restrita; e possibilidade de os Estados envolvidos interferirem diretamente no conteúdo da decisão.

3. Independência financeira: extensão dos recursos físicos e humanos disponibilizados aos decisores; remuneração concedida diretamente pelos partes da controvérsia ou pela instituição; e corpo de publicação das decisões próprio da instituição.

Por fim, em referência às variáveis que determinam os efeitos da decisão prolatada em cada controvérsia, verificam-se os seguintes elementos:

1. obrigatoriedade direta ou dependente da aprovação das partes da controvérsia; e

2. executoriedade direta ou dependente de ação das partes da controvérsia.

A partir da exposição a que se acaba de proceder, é possível estabelecer o grau de delegação de autoridade nos diversos mecanismos de solução de controvérsias que foram apresentados. Como se verifica do quadro abaixo, o mecanismo em que há a menor delegação é a negociação, visto que nem há participação de Terceiro. Por outro lado, os mecanismos jurisdicionais são aqueles em que, comparativamente, há maior delegação; dentre eles, ainda a delegação pode ser maior ou menor de acordo com seu caráter supranacional ou inter-estatal.

Os demais podem ser classificados, em ordem crescente do nível de delegação de autoridade: bons ofícios, inquérito, mediação, conciliação e arbitragem. 


\begin{tabular}{|c|c|c|c|c|c|}
\hline \multirow{2}{*}{ Procedimento } & \multirow{2}{*}{ Acesso } & \multicolumn{3}{|c|}{ Independência } & \multirow{2}{*}{$\begin{array}{c}\text { Efeitos da } \\
\text { decisão }\end{array}$} \\
\hline & & Subjetiva & Decisória & Financeira & \\
\hline Negociação & $\begin{array}{l}\text { Apenas os } \\
\text { envolvidos }\end{array}$ & n.a. & n.a. & n.a. & n.a. \\
\hline Bons Ofícios & $\begin{array}{l}\text { Apenas os } \\
\text { envolvidos }\end{array}$ & Baixa & $\begin{array}{c}\text { Sem } \\
\text { intervenção }\end{array}$ & Baixa & $\begin{array}{c}\text { Não } \\
\text { vinculante }\end{array}$ \\
\hline $\begin{array}{c}\text { Comissões de } \\
\text { Inquérito }\end{array}$ & $\begin{array}{l}\text { Apenas os } \\
\text { envolvidos }\end{array}$ & Baixa & $\begin{array}{c}\text { Apenas } \\
\text { sobre fatos }\end{array}$ & Baixa & $\begin{array}{c}\text { A.p. } \\
\text { vinculante }\end{array}$ \\
\hline Mediação & $\begin{array}{l}\text { Apenas os } \\
\text { envolvidos }\end{array}$ & Baixa & Alta & Baixa & $\begin{array}{c}\text { Não } \\
\text { vinculante }\end{array}$ \\
\hline Conciliação & $\begin{array}{l}\text { Apenas os } \\
\text { envolvidos }\end{array}$ & $\begin{array}{l}\text { Baixa a } \\
\text { moderada }\end{array}$ & Alta & Baixa & $\begin{array}{c}\text { Não } \\
\text { vinculante }\end{array}$ \\
\hline Arbitragem & $\begin{array}{l}\text { Apenas os } \\
\text { envolvidos }\end{array}$ & $\begin{array}{c}\text { Baixa a } \\
\text { moderada }\end{array}$ & $\begin{array}{l}\text { Baixa a } \\
\text { moderada }\end{array}$ & Baixa & Vinculante \\
\hline $\begin{array}{l}\text { Mecanismos } \\
\text { Jurisdicionais }\end{array}$ & $\begin{array}{c}\text { Cf. caso: } \\
\text { apenas } \\
\text { envolvidos, } \\
\text { terceiros e } \\
\text { indivíduos }\end{array}$ & $\begin{array}{c}\text { Moderada a } \\
\text { alta }\end{array}$ & $\begin{array}{c}\text { Moderada a } \\
\text { alta }\end{array}$ & Baixa a alta & $\begin{array}{l}\text { Vinculante } \\
\text { Em geral, sem } \\
\text { aplicação } \\
\text { direta }\end{array}$ \\
\hline
\end{tabular}

Quadro 2: Delegação de autoridade nos mecanismos de solução de controvérsias Legenda: n.a.: não aplicável; cf.: conforme.

\subsection{Conclusão}

De acordo com a teoria sobre juridicização desenvolvida por K. W. ABBOTT et al (2000), as características do órgão ao qual se delega a autoridade para solucionar as controvérsias que surgem no âmbito do sistema são elemento decisivo para definição do grau de juridicidade. Assim, quanto mais houver acesso ao sistema, independência do órgão e efeito direto das decisões deste emanadas, mais juridicidade terá um determinado sistema.

As características a serem consideradas por este modelo somente passam a ser relevantes após sua formalização por meio de regras que estabelecem o processo de 
institucionalização. Neste sentido, nos primeiros níveis do Quadro 1 acima, prevalecem as normas de direito mais rígidas e formalizadas, enquanto, nos níveis mais baixos, prevalecem as formas mais suaves, que não implicam no reconhecimento de obrigações específicas que podem ser executadas pelos interessados. 


\section{REGULAMENTAÇÃO DA SOLUÇÃO DE CONTROVÉRSIAS PELO SISTEMA MULTILATERAL DE COMÉRCIO}

\subsection{Notas Introdutórias}

Após a explanação do modelo teórico a ser utilizado nesta pesquisa no capítulo anterior, o objetivo do presente capítulo consiste em aplicar tal modelo teórico para análise do sistema de solução de controvérsias no âmbito do sistema multilateral de comércio.

Para tanto, num primeiro momento, com o intuito de contextualização, serão explicados, em linhas gerais, os procedimentos de solução de controvérsias encontrados na prática do sistema multilateral de comércio (item 2.2), ou seja, no GATT-1947 (item 2.2.1) e na OMC (item 2.2.2). No caso do GATT-1947, antes de se passar à apresentação de sua regulamentação, procede-se à indicação das dificuldades encontradas para conformação do quadro descritivo (item 2.2.1.1).

Em seguida, apenas os procedimentos relevantes serão analisados a partir das categorias comentadas no capítulo anterior (item 2.3). Por fim, serão apresentadas as notas conclusivas que podem ser aduzidas da análise apresentada ao longo deste capítulo (item 2.4).

\subsection{Regulamentação dos procedimentos}

Como será demonstrado abaixo, o texto do GATT-1947 não fazia menção expressa a sistema detalhado de solução de controvérsias entre suas partes contratantes. De fato, nem mesmo a expressão "solução de controvérsias" fora inserida em seu texto. Os procedimentos foram desenvolvidos na prática da organização e regidos, posteriormente, pelos seguintes instrumentos: 
1. Decisão de 5 de abril de 1966 sobre os Procedimentos do Art. XXIII [Decisão de 1966] 59

2. Documentos resultantes da Rodada Tóquio de negociações comerciais multilaterais (1974-1979): (i) o Entendimento sobre Notificação, Consulta, Solução de Controvérsias e Supervisão de 1979 [Entendimento de 1979] ${ }^{60}$; e (ii) os diversos "códigos"61;

3. Declaração Ministerial de 29 de novembro de 1982, Decisão sobre Solução de Controvérsias [Decisão de 1982] ${ }^{62}$;

4. Decisão sobre Solução de Controvérsias de 30 de novembro de 1984 [Decisão de $1984]^{63}$;

5. Decisão de 12 de abril de 1989 sobre Aprimoramentos das Regras e dos Procedimentos do GATT relativos6 à Solução de Controvérsias [Decisão de 1989] ${ }^{64}$; e

6. Decisão de 22 de fevereiro de 1994 sobre a Extensão da Decisão de Abril de 1989 sobre Aprimoramentos das Regras e dos Procedimentos do GATT relativos à Solução de Controvérsias [Decisão de 1994] $]^{65}$.

Por sua vez, o sistema de solução de controvérsias da OMC foi estabelecido pelo Entendimento sobre Solução de Controvérsias, incorporado no Anexo 2 do Acordo de Marraqueche.

\subsubsection{GATT-1947}

59 Texto disponível no Anexo C.

${ }^{60}$ Texto disponível no Anexo D.

${ }^{61}$ Os códigos adotados ao final da Rodada Tóquio foram os seguintes: o Acordo sobre Barreiras Técnicas ao Comércio [Código sobre Padrões]; o Acordo sobre Compras Governamentais; o Acordo sobre Interpretação e Aplicação dos Artigos VI, XVI e XXIII do GATT [Código sobre Subsídios]; o Acordo relativo à Carne Bovina; o Acordo International sobre Laticínios; o Acordo sobre Implementação do Artigo VII do GATT [Acordo sobre Valoração Aduaneira]; o Acordo sobre Procedimentos para Licenciamento de Importações; o Acordo sobre o Comércio de Aeronaves Civis; e o Acordo sobre Implementação do Artigo VI [Código Antidumping]. Um país ou território aduaneiro independente poderia ser parte de nenhum, um ou todos os códigos, independentemente de ser parte contratante do GATT-1947.

62 Texto disponível no Anexo E.

${ }^{63}$ Texto disponível no Anexo F.

${ }^{64}$ Texto disponível no Anexo G.

${ }^{65}$ Texto disponível no Anexo H. 


\subsubsection{Dificuldades na análise dos procedimentos de solução de controvérsias sob a vigência do GATT-1947}

Embora esta pesquisa apresente uma análise descritiva da prática relativa aos procedimentos de solução de controvérsias no âmbito do GATT-1947, devido às dificuldades abaixo arroladas na compilação de fontes primárias das informações necessárias para formação de seu quadro, indica-se a possibilidade de que esta descrição possa vir a ser complementada, futuramente, com informações que, no momento, não são acessíveis.

A primeira dificuldade a se ressaltar nesta análise consiste na inexistência de um banco de dados que contenha todos os documentos oficiais disponibilizados para acesso à longa distância. As duas bases mais utilizadas para esta pesquisa foram a da Universidade de $\operatorname{Stanford}^{66}$ e a página eletrônica da $\mathrm{OMC}$, que, apenas recentemente, disponibilizou os documentos do GATT-1947 sob sua guarda que havia tido a oportunidade de microfilmar ${ }^{67}$.

Ambas as bases contêm milhares de documentos à disposição para pesquisa pela Internet. $\mathrm{Na}$ prática, contudo, o mecanismo de busca não possibilita pesquisa avançada no conteúdo dos documentos, e não existe uma indexação comentada dos documentos ali encontrados.

A falta de uma indexação trabalha contra a otimização da atividade de pesquisa. Neste sentido, por exemplo, os documentos emitidos pelo Secretariado do GATT-1947, ao longo de todo o período de vigência deste acordo, podem ser classificados tanto com as siglas ICITO quanto com a letra L. Os documentos classificados com esta letra, por sua vez, abrangem temas que vão das comunicações e prestações de contas do Secretariado, até as notas das partes contratantes que eram circuladas pelo Secretariado, passando pelos relatórios de painéis, dentre outros.

Observa-se, ainda, que a base de dados disponibilizada pela OMC não dispõe de nenhum recurso de pesquisa em seu conteúdo. Os documentos podem ser encontrados

\footnotetext{
${ }^{66}$ Disponível a partir do seguinte endereço: <gatt.stanford.edu>.

67 V. WTO (PRESS/442). A base de dados encontra-se disponível a partir do seguinte endereço: $<$ http://www.wto.org/english/docs_e/gattdocs_e.htm>.
} 
por sua sigla ou por sua data, a partir de parâmetros fixos formulados pela própria organização.

Outra dificuldade que pode levar à não completude do quadro descritivo consiste na informalidade dos procedimentos de solução de controvérsias que, por vezes, eram alterados por decisão do próprio Secretário Geral, sem documentação específica que explicasse esta alteração. A explicação para estes fenômenos e sua contextualização poderiam ser buscadas por meio de entrevistas e outros procedimentos que implicariam no dispêndio de recursos não disponíveis para esta pesquisa específica.

\subsubsection{Regulamentação dos procedimentos de solução de controvérsias}

Na redação do GATT-1947, não há referência nenhuma à expressão solução de controvérsias entre suas partes contratantes. De fato, os únicos dispositivos do acordo que estão relacionados à solução de controvérsias são os artigos XXII, referente a consultas, e XXIII, referente a dano e prejuízo dos benefícios auferidos ${ }^{68}$.

De acordo com o Artigo XXII, as partes contratantes do GATT-1947 deveriam ser receptivas aos pedidos de consultas bilaterais apresentados por outras partes contratantes com relação a qualquer assunto que afete a operação do acordo. A princípio, não havia o dever de notificação às Partes Contratantes das solicitações de consultas apresentadas com base neste artigo ${ }^{69}$.

\footnotetext{
${ }^{68}$ De acordo com o relatório USITC (1985:9): “The only amendments to articles XXII and XXIII of GATT since 1947 were adopted by the Contracting Parties at the Ninth Session in 1955 and entered into force in October 1957. Article XXII was amended by adding a new paragraph providing for joint consultation with the CP if bilateral consultations do not yield a satisfactory result. The last two sentences of Article XXIII were also slightly modified, but the amendments were minor in nature". A versão em português da redação original dos dois referidos artigos encontra-se no Anexo II. Por sua vez, a versão em inglês do artigo XXII é a seguinte, cf. OMC (WT/DS58/R:§3.178): "Each contracting party shall accord sympathetic consideration to, and shall afford adequate opportunity for consultation regarding, such representations as may be made by another contracting party with respect to the operation of customs regulations and formalities, anti dumping and countervailing duties, quantitative and exchange regulations, subsidies, state trading operations, sanitary laws and regulations for the protection of human, animal or plant life or health, and generally all matters affecting the operation of this Agreement".

${ }^{69}$ O texto do GATT-1947 não se manifestava sobre a necessidade de notificação, razão pela qual as partes contratantes entendiam que não existiria. Isto foi reconhecido em texto produzido durante as negociações da Rodada Tóquio (GATT: MTN/SG/W/8,7): “Under the General Agreement bilateral consultations must take place before disputes can be referred to the Contracting Parties. While the Secretariat does not have systematic information on bilateral consultations since ps have no obligation to notify these, it seems clear
} 
Esta situação foi alterada em $1955^{70}$, quando, além de se incorporar a notificação, inseriu-se o segundo parágrafo ao artigo, o qual determina que as Partes Contratantes podem, mediante pedido específico, consultar com as partes da controvérsia quando não tiver sido possível alcançar solução mutuamente acordada. Esta inclusão foi realizada, porque, até então, os pedidos de consultas apresentados com base neste artigo eram estritamente bilaterais e não permitiam a participação das Partes Contratantes, cuja intervenção deveria ser solicitada com base no artigo XXIII.

Por sua vez, o Artigo XXIII estabelece o procedimento a ser seguido nos casos em que uma parte contratante julga que (i) os benefícios que auferia em razão do acordo tenham sido objeto de dano ou prejuízo ou (ii) a consecução de qualquer objetivo do GATT-1947 tenha sido impedida, em razão de uma ou mais das seguintes hipóteses: (i) não observância de suas obrigações por uma parte contratante; (ii) implementação de medida (independentemente de esta ser incompatível com os termos do GATT-1947); e/ou (iii) existência de qualquer outra situação ${ }^{71}$. Nestes casos a parte contratante interessada poderia solicitar consultas com a outra parte apropriada.

Nos casos em que não fosse possível solução mutuamente acordada entre as partes da controvérsia, a parte contratante interessada poderia levar a disputa ao conhecimento das Partes Contratantes. Caberia a este órgão investigar, prontamente, a questão, a fim de emitir decisão, recomendação ou autorizar a suspensão das concessões para a parte que mantivesse a medida questionada, nos casos em que a situação fosse grave o suficiente para justificar tal medida.

Como se pode observar, portanto, o GATT-1947 não estabelecia procedimento detalhado de solução de controvérsias entre suas partes contratantes. Isso se deve, em parte, em razão do fato de o GATT-1947, em sua origem, ter sido concebido como um acordo a vigorar apenas provisoriamente ${ }^{72}$, visto que a entrada em vigor da Carta da OIC esta sim com procedimento detalhado de solução de controvérsias - ab-rogá-lo-ia ${ }^{73}$.

from the fact that only twenty-five Article XXIII:2 cases have arisen in GATT's 28 year history that most disputes have been settled bilaterally".

${ }^{70} \mathrm{~V}$. nota de rodapé 68 acima.

${ }^{71}$ Observa-se, portanto, que são possíveis seis tipos de ações com base no primeiro parágrafo do artigo XXIII do GATT-1947. Explicação detalhada sobre tais ações e comentários a respeito de sua utilização podem ser encontrados em E. ULRICH-PETERSMANN (1998:72ss).

72 A Carta da OIC compreendia os seguintes capítulos: I, Purpose and Objectives; II, Employment and Economic Activity; III, Economic Development and Reconstruction; IV, Commercial Policy; V, Restrictive 
De acordo com R. E. HuDEC (1998:102-103), há ainda outras razões que podem ser apresentadas para justificar a simplicidade daquela regulamentação. Nesse sentido, o mandato de negociação possuído pelos representantes estadunidenses era limitado, de modo que, para que o acordo pudesse ser aplicado por seu país, deveria ser classificado como um acordo de comércio, em nada semelhante a uma organização internacional ${ }^{74}$. Além disso, em razão da necessidade de evitar procedimentos formais de

Business Practices; VI, Inter-Governmental Commodity Agreements; VII, The International Trade Organization; VIII, Settlement of Differences; e IX, General Provisions. Com relação ao sistema de solução de controvérsias, que era regulamentado pelo capítulo VIII (artigos 92-97), previam-se os seguintes procedimentos: consultas, arbitragem, intervenção do Conselho Executivo, intervenção da Conferência e recurso à CIJ. Os membros comprometiam-se a recorrer apenas aos procedimentos previstos na Carta para solução das eventuais controvérsias que surgissem entre eles sobre a aplicação do tratado (artigo 92:1). Ademais, comprometiam-se a não procederem a medidas econômicas unilaterais contrárias às disposições da Carta (artigo 92:2). O texto destes artigos encontra-se no Anexo A.

${ }^{73}$ Cf. ECOSOC (E/PC/T/214.Add.2 Rev.1): "The governments of (...) undertake, provided that this Protocol shall have been signed on behalf of all the foregoing governments not later than November, 1947, to apply provisionally on and after January 1, 1948: (a) Parts I and III of the General Agreement on Tariffs and Trade, and (b) àrt II of thata Agreement to the fullest extent not inconsistent with existing legislation".

74 A versão final incorporada ao GATT-1947 de ambos os artigos é resultante da proposta estadunidense de 1945 para inclusão de dispositivos sobre solução de controvérsias na Carta da OIC. De acordo com o relatório do USITC (1985:8), o primeiro parágrafo da minuta de Londres/Nova Iorque que dispunha sobre consultas foi incorporado ao GATT-1947 após certa edição e se transformou no artigo XXIII; por sua vez, os dois primeiros artigos da minuta de Genebra referentes a consultas e intervenção da OIC foram incluídos, mutatis mutandis, sem referência à arbitragem. O primeiro parágrafo da minuta de Nova Iorque (ECOSOC:E/PC/T/C.6/85) era o seguinte: “ARTICLE XIX - Consultation - Nullfication or Impairment: 1. Each contracting party will accord sympathetic consideration to, and will afford adequate opportunity for consultation regarding, such representations as may be made by any other contracting party with respect to the operation of customs regulations and formalities, anti-dumping and countervailing duties quantitative and exchange regulations .subsidies, state -trading operations, sanitary laws and regulations for the protection of human, animal or plant life or health; and generally all Matters affecting the operation of this Agreement and will, in the course of such consultation, provide the other contracting part with such information as will, without prejudicing the legitimate. Business interests of particular business enterprises, enable a full and far appraisal of the situation which is the subject of such representations". Por sua vez, os referidos parágrafos da minuta de Genebra (ECOSOC:E/PC/T/189) eram os seguintes: "Article XXX Nullification or Impairment: If any contracting party should consider that any benefit accruing it directly or indirectly under this Agreement or its accompanying Protocol is being nullified or impaired or any objective of the Agreement is being impeded as the result of (i) the failure of another contracting party to carry out its obligations under this Agreement or the accompanying Protocol, or (ii) the application by another contracting party of any measure, whether or not it conflicts with the provisions of this Agreement; or (iii) the existence of any other situation, the contracting party may, with a view to the satisfactory adjustment of the matter, make written representations or proposals to the other contracting party or parties which it considers to be concerned. Any contracting party thus approached shall give sympathetic consideration to the representations or proposals made to it. If no satisfactory adjustment is effected between the contracting parties concerned within a reasonable time, or if the difficulty is of the type described in (iii) above, the matter may be referred to the Committee. The Committee shall promptly investigate any matter so referred to it and make appropriate recommendations to the contracting parties which it considers to be concerned or give a ruling on the matter, as appropriate. The Committee may consult with contracting parties, with the Economic and Social Council of the United Nations and with any appropriate inter-governmental organizations in cases where it considers such consultation necessary. If the Committee considers that the circumstances are serious enough to justify such action, it may authorize a contracting party or parties to suspend the application to such other contracting party or parties of such obligations or concessions under this Agreement as the Committee determines to be appropriate in the circumstances. If the application to any 
ratificação que atrasassem o processo de entrada em vigor do acordo, a natureza do compromisso não deveria ser a mesma de um compromisso legal definitivo. Por fim, até o momento de sua redação, não haviam sido definidas as conseqüências derivadas dos diversos tipos de reclamações previstos no acordo. ${ }^{75}$

Ao contrário das expectativas, a OIC não entrou em vigor - razão pela qual o GATT-1947, que era um instrumento provisório, continuou a regulamentar as relações comerciais de suas partes contratantes ${ }^{76}$. Diante da falta de especificação dos procedimentos a serem seguidos diante do surgimento de disputas entre suas partes, as primeiras controvérsias foram solucionadas por meio da intervenção do presidente das Partes Contratantes ${ }^{77}$.

Isto, contudo, ocorreu apenas ao longo das primeira e segunda sessões das Partes Contratantes ${ }^{78}$, visto que, na terceira sessão, iniciou-se nova fase com o estabelecimento de grupo de trabalho para análise de cada disputa que surgisse ${ }^{79}$.

contracting party of any obligation or concession is in fact suspended, that contracting party shall then be free, not later than sixty days after such action is taken, to advise the Committee in writing of its intention to withdraw from this Agreement and such withdrawal shall take effect upon the expiration of sixty days from the day on which written notice of such withdrawal is received by the Committee".

${ }^{75}$ Conforme O. LONG (1987:65), as seguintes razões também explicariam a precariedade dos dispositivos do GATT-1947 relacionados à solução de controvérsias: " $A$ further factor was the sentiment widely felt - and still shared by GATT member countries - that, as Malinverni puts it, if a legal solution is applied in an international organisation, this does not necessarily safeguard the spirit of collaboration amongst its members. On the contrary, it can compromise it. Moreover, in international organizations, a dispute is considered less as a conflict of interests between states, to be settled by application of the law, than as an obstacle to its good function". OLIVIER LONG foi Diretor Geral do Secretariado do GATT-1947 entre 1968 e 1980; e exemplifica o sentimento que predominava à época.

$76 \mathrm{Na}$ década de 1950, as partes contratantes chegaram a dar início às negociações de uma eventual Organização de Cooperação Comercial. Esta, contudo, não chegou a tomar corpo, e as negociações não foram continuadas. A respeito deste tema, v. J. W. MitChELL (1955-1956).

${ }^{77}$ De acordo com R. E. HUDEC (1998:104): "the first few legal rulings overcame both the time pressure and the neutrality problem by the device of a ruling from the chair, which became a ruling of the entire membership when it was tacitly approved by silence. This device was accepted as sufficiently neutral for two rather special reasons. First, the Chairman of the Contracting Parties during the first four sessions was $L$. Dana Wilgress, a senior Canadian diplomat who had also been Chairman of the 1946-1948 GATT/ITO negotiations. Wilgress' key role in those negotiations lent an unusual degree of authority to his rulings, both because of his expertise as to the meaning of the agreement and because of the reputation for fairness he had earned in his work as chairman of the ITO negotiations. Second, and perhaps more important, in these early years most of the delegates to GATT meetings were also veterans of the GATT/ITO negotiations themselves". Outros comentários sobre esta fase podem ser encontrados em GATT (MTN/SG/W/8:2) e USITC (1985:12).

78 De fato, como ilustrado por E. REINHARDT (1996), as primeiras controvérsias sugiram apenas durante a segunda sessão das Partes Contratantes, realizada em Genebra entre julho e setembro d 1948.

${ }^{79}$ Até o momento de conclusão desta dissertação, o documento que estabeleceu o primeiro grupo de trabalho (CP.2/SR.11) não se encontra disponível nem na base de dados da Universidade de Stanford nem na da OMC. A referência ao documento foi encontrada em GATT (MTN/SG/W/8:2). 
Neste momento, os casos são discutidos no plenário das Partes Contratantes, depois no âmbito do grupo de trabalho (composto pelas partes da controvérsia e outras partes contratante interessadas) e, por fim, novamente, naquele plenário, para exame do relatório produzido pelo grupo de trabalho criado para análise da disputa ${ }^{80}$. O objetivo do estabelecimento do grupo de trabalho consistia em permitir que seus integrantes chegassem a consenso sobre a disputa e emitir relatório que o refletisse.

Sem regulamentação específica, contudo, os procedimentos no âmbito dos grupos de trabalho modificaram-se e passaram a restringir a participação das partes da controvérsia na elaboração do relatório a ser emitido, na tentativa de se tornarem um fórum neutro para solução da controvérsia analisada ${ }^{81}$. De acordo com R. E. HUDEC (1998), tal como ocorrera com os primeiros relatórios preparados pelo presidente das Partes Contratantes, este novo perfil dos grupos de trabalhos foi aceito a despeito de suas "origens irregulares" $"$.

De forma complementar, as dificuldades encontradas na prática dos grupos de trabalho $^{83}$ acabaram por levar à nova modificação dos procedimentos de solução de controvérsias. Desta feita, durante a sétima sessão das Partes Contratantes, em 1952, foi

\footnotetext{
${ }^{80}$ Para comentário sobre a prática, v. GATT (MTN/SG/W/8:2; L/392:1).

${ }^{81}$ De acordo com USITC (1985:14-15): “The working party in the Australian subsidy case went further and involved what was for the first time tantamount to a third-party adjudication. The working party consisted of the two principals, Australia and Chile, and three neutrals members, the United States, the United Kingdom, and Norway. The neutrals considered the arguments of the two principals and concluded that Chile had a valid claim of nullification. However, Australia disagreed and filed a separate statement outlining its position. As a result of a lobbying effort on both sides, the decision was in effect appealed to the Contracting Parties for a final ruling. However, the Contracting Parties declined to be drawn into the case and approved the working party report virtually without discussion".

${ }^{82} \mathrm{O}$ autor explica: "Once again, the main factor underlying their acceptance was the fact that most of the ITO veterans serving as GATT delegates were confident that they knew what the agreement meant. It also helped that most working parties had delegates from the United States, United Kingdom and France - the three most influential delegations that had not only done most of the actual drafting of the GATT/ITO agreements, but had in fact dictated most of their substance".

${ }^{83}$ Conforme explicação encontrada em GATT (L/392:1): "Although this traditional method of dealing with consultations, reports and even complaints has the advantage of permitting a frank exchange of views under conditions in which all delegations meet on an equal footing, experience has revealed that it also has disadvantages. In the case of complaints, for example, it often proved embarrassing for the representative of a country against which a complaint was lodged to associate himself with the working party report. On the other hand, it was often equally embarrassing for him to dissent from the report and to file a minority statement. Furthermore, the majority of the working party themselves were frequently inhibited in a frank expression of views in their report to the CONTRACTING PARTIES because of their desire to reach unanimous agreement in the working party. These difficulties became so apparent during the early sessions of the CONTRACTING PARTIES that by their Seventh Session they adopted a radically different procedure and established a Panel on Complaints".
} 
estabelecido um painel para análise de todas as controvérsias que surgissem durante aquela sessão $^{84} 85$.

De acordo com R. E. HUDEC (1998:107), a origem da utilização do termo painel - não previsto no GATT-1947 - deveu-se ao seguinte fator:

"The term panel in GATT parlance came from the term panel of experts - a term coined long before GATT to describe an ad hoc group of government experts (rather than policy officials) convened to render an expert opinion about some technical question that is capable of being answered objectively. The term thus connoted objective decisions based on expertise rather than political representation of one's government'.

Não obstante a vontade de tornar mais objetiva e neutra a elaboração do relatório sobre a disputa, o estabelecimento do painel da sétima sessão assemelhou-se à prática dos grupos de trabalho. Nesse sentido, a indicação dos integrantes dos painéis referia-se a países e não a indivíduos ${ }^{86}$.

Da mesma forma como ocorria com os grupos de trabalho, a disputa surgia no âmbito das Partes Contratantes, era estabelecido um painel para sua análise, que emitia um relatório, o qual voltava para análise e fundamentação da decisão a ser proferida pelas Partes Contratantes para a controvérsia ${ }^{87}$.

A prática de indicação de painéis para análise de todas as controvérsias surgidas durante uma sessão das Partes Contratantes perdurou até 1955, quando passaram a

\footnotetext{
${ }^{84}$ A criação do painel deu-se nos seguintes termos, cf. GATT (SR.7/7:7): "The chairman recalled that it had been agreed at the fifth meeting to establish a panel to hear the various complaints that might be referred to it by the CONTRACTING PARTIES during the present Session. He now suggested that this Panel be composed of Australia Canada Ceylon Cuba Finland Netherlands".

${ }^{85}$ Para detalhes sobre o contexto de adoção de painéis, v. GATT (MTN/SG/W/8:3; L/392:2).

${ }^{86} \mathrm{~V}$. nota de rodapé 84 acima.

${ }^{87}$ Conforme indicado por USITC (1985:16): "The change of procedure was considered to represent a relatively minor modification of existing practice. However, in practice the panel approach represented a major departure from the previous working party approach in several important respects. First, the panel did not include representatives from the countries filing the complaints. Second, the panel did not include representatives from the major trading nations, such as the United States or the United Kingdom. Third, the panel and the Secretariat worked out new procedures that were more formal and courtlike (...) Because the parties were not present at the decision making stage under this new approach, they were forced, as a practical matter, to organize their cases and put their arguments in writing to ensure that the relevant facts and arguments would be before the panel at the time of decision. In addition, the new approach allowed the panel the freedom to deliberate in private, but it also forced the panel to formalize the proceedings and tended toward a more independent consideration of the relevant facts, on the basis of which a decision could ultimately be made". V. também R. E. HUDEC (1998:108).
} 
ser indicados painéis ad hoc para análise de cada disputa em separado. Esta modificação deveu-se à revisão realizada por comitê criado naquele ano $^{88}$.

Todas as modificações apresentadas até o momento foram realizadas na prática dos procedimentos, sem institucionalização. Esta realidade é refletida na nota de rodapé ao primeiro parágrafo do Anexo do Entendimento 1979, a qual declara, expressamente:

"At the review session (1955) the proposal to institutionalize the
procedures of panels was not adopted by CPs mainly because they
preferred to preserve the existing situation and not to establish
judicial procedures which might put excessive strain on the GATT".

Os primeiros passos rumo à institucionalização dos procedimentos de solução de controvérsias, no âmbito do GATT-1947, deram-se em razão da busca de tratamento especial e diferenciado para os países em desenvolvimento ${ }^{89}$. Nesse sentido, foi adotada a

${ }^{88}$ Para comentários sobre esta fase, v. GATT (MTN/SG/W/8:3) e USITC (1985:19). Dentre os pontos objetivados pela revisão dos procedimentos, encontrava-se a preocupação com maior transparência das informações que eram trocadas pelas partes da disputa ao longo dos procedimentos. Seu contexto encontra-se expresso no documento que a embasou, qual seja GATT (L/392:1): "When the provisions relating to the balance-of-payment consultations were reviewed at the Ninth Sessiont it was emphasized by several delegates that, if consultations carried out by the contracting parties were to be effective, improved arrangements for the competent and speedy conduct of the consultations would be necessary. This question was also discussed in connexion with the continuing administration of the Agreement, and the Danish delegation submitted a suggestion for the appointment of panels of qualified representatives to assist in carrying out consultations under Articles XII to XIV and in the consideration of of complaints under Article XXIII, as well as other commercial policy matters which are the subject of regular reports for examination by the CONTRACTING PARTIES (see Third Supplement, pages 179 and 247). There was no general agreement on the suggestion put forward by the Danish delegation, and no other specific proposal was submitted, but it was agreed that the Executive Secretary should consider the problem and, if possible, put forward concrete proposals for consideration at the Tenth Session".

${ }^{89}$ No início da década de 60, o Uruguai iniciou uma série de demandas contra 576 restrições comerciais de 15 PDs que afetavam suas exportações . O Uruguai alegava desequilíbrio geral dos benefícios que lhe eram devidos, e seus procedimentos eram todos de não violação. Não obstante tenha pedido o julgamento da legalidade das medidas referidas, o Uruguai não apresentou provas ou argumentos substanciais que fundamentassem sua demanda. De fato, o Uruguai recusou-se a apresentar qualquer prova estatística ou argumentos sobre a questão do dano comercial. Cf. P. E. KURUVILA (1997:189), diz-se que o Uruguai adotou atitude passiva em virtude do temor de provocar os PDs individualmente. Este caso passou por três painéis e, no fim, foi tomado como tentativa de chamar a atenção para os problemas que os países em desenvolvimento enfrentavam, principalmente, os relativos à coleta de informações e à apresentação de complicados argumentos legais. As demandas uruguaias foram o primeiro passo de um movimento dos países em desenvolvimento por um tratamento que lhes permitisse a utilização efetiva do sistema GATT em seu benefício. As demandas são descritas mais detalhadamente por R. E. HudEC (1975:220) e P. E. KURUVILA (1997:189). Em 1965, Brasil e Uruguai apresentaram proposta de reforma do Art. XXIII do GATT. Tal proposta visava não a um aprimoramento geral do sistema em si, mas à criação de um sistema diferenciado para os países em desenvolvimento. Cf. R. E. HUDEC (1975:222), as principais demandas dos dois países eram: (i) aos países em desenvolvimento deveriam ser facultadas a apresentação de demandas por terceiros em seu nome e a prestação de assistência técnica para capacitação referente à participação no sistema de solução de controvérsias; (ii) nos casos em que fosse constatado que um país desenvolvido violou suas obrigações em face a um país em desenvolvimento, àquele caberia a obrigação de compensar este 
Decisão de 1966 para reger os procedimentos de solução de controvérsias iniciadas por países em desenvolvimento em face de país desenvolvido.

A referida decisão estabelecia os seguintes procedimentos: negociação, bons ofícios e intervenção das Partes Contratantes. De certa forma, esta decisão formalizou os procedimentos até então seguidos informalmente, com a inclusão da possibilidade de oferecimento de bons ofícios pelo Diretor Geral. De acordo com P. E. KURUVILA (1997), entre 1966 e 1994, os bons ofícios do Diretor Geral foram oferecidos apenas em três casos. No que se refere à utilização da decisão para fundamentar o estabelecimento de um painel, R. E. HUDEC (1998) afirma que, no período entre sua adoção e 1980, foi utilizada apenas em uma ocasião: no caso entre o Chile e as CE, em que demandante desistiu da demanda após tens negociação.

Este cenário modificou-se ao fim da Rodada Tóquio de negociações comerciais multilaterais, quando passam a coexistirem três conjuntos de procedimentos de solução de controvérsias no âmbito do sistema multilateral de comércio: $1^{\circ}$ a própria Decisão de 1966 - cujos termos não foram modificados pelas negociações ${ }^{90} ; 2^{\circ}$ o procedimento geral relativo às violações das regras do GATT-1947 aprovado com o Entendimento de 1979; e $3^{\circ}$ a regulamentação prevista em cada um dos códigos adotados ao fim da rodada ${ }^{91}$.

A declaração que conformou o mandato para as negociações da Rodada Tóquio não previa, expressamente, negociações sobre solução de controvérsias (GATT: MIN(73)SR). De acordo com R. E. HUdEC (1980:157):

"The actual negotiations began in early 1975. (...) The negotiators promptly realized that writing rules would be a waste of time

financeiramente pelas perdas realizadas; (iii) os países em desenvolvimento poderiam não observar suas obrigações em face a países desenvolvidos que mantivessem medidas incompatíveis com GATT-1947; e (iv) possibilidade de se iniciar ação coletiva para obter implementação de uma decisão em favor de um países em desenvolvimento que não tivesse sido devidamente cumprida em prazo específico (devido à preocupação com a incapacidade de os países em desenvolvimento retaliarem os países desenvolvidos). Para maiores informações sobre a relação entre os países em desenvolvimento e o sistema de solução de controvérsias, no âmbito do sistema multilateral de comércio, v. A. DO AMARAL JR. et al (2006:26ss).

${ }^{90}$ Parágrafo 7 do Entendimento de 1979: “(...) The Contracting Parties reaffirms that the customary practice includes the procedures for the settlement of the disputes between developed and less-developed countries adopted by the Contracting Parties in 1966 and that these remain available to less-developed contracting parties wishing to use them".

${ }^{91}$ De acordo com O. LONG (1987:78): "Part of the explanation [para os diferentes procedimentos previstos nos códigos adotados] is the specific nature of each subject matter. Another reason (...) is that there was insufficient time for the negotiators to harmonize the provisions on dispute settlement in the various nontariff barrier agreements, and to bring them into line with those of the General Agreement". 
unless a strong enforcement procedure accompanied the code. As a result, the text of each code grew to contain its own disputesettlement procedure. Due to the diverse subject matter of the various codes and the different negotiators involved, these early efforts contained a variety of approaches to dispute settlement. Article XXIII, the GATT's general dispute-settlement procedure, did not appear on the formal negotiating agenda until November 1976". Nota de rodapé: "The context was a proposal by Brazil to establish a new negotiating sector, the Framework Group, to deal with general issues pertaining to the legal framework of GATT', ${ }^{92}$

De fato, as negociações da Rodada Tóquio ocorreram num momento em que as partes contratantes voltavam a recorrer ao sistema de solução de controvérsias do GATT1947 para resolver suas disputas, após um período de quase uma década de, praticamente, nenhuma movimentação ${ }^{93}$.

O objetivo dos negociadores com relação à solução de controvérsias, no entanto, consistia em reafirmar a prática então vigente do GATT-1947 e aumentar, em certa medida, o seu grau de precisão (USITC, 1980:27) ${ }^{94}$. Embora os documentos adotados ao final da rodada não tenham revolucionado a regulamentação dos procedimentos de solução de controvérsias, ao menos, institucionalizaram a prática informal vigente ${ }^{95}$.

\footnotetext{
${ }^{92}$ V. também as observações contidas em USITC (1980:26).

${ }^{93}$ Esta retomada está relacionada, especialmente, aos EUA, cf. R. E. HUDEC (1998:110): “The United States deserted the anti-legalistic camp in the early 1970s. Broadly speaking, the change was triggered by growing concern about two parallel strains of increasing protectionism - the rise of protectionism in the US Congress and also a general increase in non-tariff trade barriers (NTBs) around the world. The US decided to attack this problem by seeking to launch a new round of GATT trade negotiations aimed at the NTB problem. Strengthening GATT's legal machinery became an essential element of that strategy for two reasons. First, the best legal technique for removing NTBs was to write more specific general rules covering the non-tariff measures in question, and such rules would require effective dispute settlement for their enforcement. Second, it was believed that the US Congress would not grant authority to negotiate new commitments on NTBs unless the Executive Branch could demonstrate the will and the ability to enforce those commitments. $A$ visible and successful adjudication procedure was a familiar symbol of effective enforcement, particularly to an American audience. (...) Then, towards the end of the decade, the United States used the Tokyo Round trade negotiations to press for a series of reforms that would strengthen the disputes procedure further". V. também R. E. HUDEC (1975).

94 Neste sentido, v. o parágrafo 9 do Entendimento de 1979: "The Contracting Parties agree that the customary practice of the GATT in the field of dispute settlement, described in the Annex, should be continued in the future, with the improvements set out below".

95 Cf. R. E. HUDEC (1980:158): “The fundamental political constraints that limit GATT regulatory policy had not changed. The Tokyo Round debate over dispute settlement never seriously questioned the assumption that the GATT would continue to rely on the essentially normative force of declaratory rulings such as those produced by the existing panel procedure. (...) The idea of adopting a more formal juridical structure was also raised and discussed seriously in some quarters, but it never received enough support to be advanced formally".
} 
O Entendimento de 1979 foi composto por duas partes: as cláusulas operativas que especificam os procedimentos de solução de controvérsias; e um anexo que continha a descrição acordada das práticas até então adotadas em relação aos procedimentos de solução de controvérsias. Os procedimentos previstos pelo Entendimento de 1979 eram os seguintes: consultas, bons ofícios e intervenção das Partes Contratantes.

Enquanto a Decisão de 1966 previa o oferecimento de bons ofícios pelo Diretor Geral nas controvérsias entre países em desenvolvimento e países desenvolvidos, o Entendimento de 1979 dispunha que as parte deveriam solicitar os bons ofícios aos indivíduos ou órgãos que julgassem apropriados (parágrafo 8). Esta disposição foi alterada pela Decisão de 1982, a qual estendeu o direito de solicitar os bons ofícios do Diretor Geral a toda e qualquer parte contratante (parágrafo $i$ ).

Por sua vez, a intervenção das Partes Contratantes na disputa poderia ser solicitada por meio do estabelecimento de um painel ou de um grupo de trabalho (parágrafo 10), caso as partes da controvérsia não alcançassem uma solução mutuamente acordada. Seus relatórios, quando emitidos, seriam utilizados como subsídio para formação da decisão a ser dada pelas Partes Contratantes.

Os sistemas previstos pelos diversos códigos adotados, contudo, eram distintos. De fato, enquanto o Entendimento de 1979 poderia ser considerado a formalização dos procedimentos vigentes, alguns códigos, de fato, criaram novos direitos e obrigações. Nesse sentido, os códigos poderiam ser classificados em duas categorias (USITC, 1985:31):

1. aqueles que não criaram novas obrigações e seguem, em parte, o próprio Entendimento de 1979 são os seguintes: o Acordo sobre Carne Bovina, o Acordo Internacional sobre Laticínios, o Acordo sobre Comércio de Aeronaves Civis e o Acordo sobre Licenciamento de Importações; e

2. os códigos os quais incorporaram novidades, quais sejam: o Código sobre Padrões, o Código sobre Valoração Aduaneira, o Código sobre Compras Governamentais, o Código sobre Subsídios e o Código Antidumping.

Em linhas gerais, todos os códigos do segundo grupo estabeleceram um sistema com as seguintes fases: consultas, conciliação voluntária e intervenção do comitê, 
ou conselho, específico ${ }^{96}$. A intervenção do comitê, ou do conselho, poderia se dar pelo estabelecimento de um grupo de trabalho ou de um painel para análise da disputa e emissão de relatório, o qual serviria como base para sua decisão.

Após o fim da Rodada Tóquio, a primeira modificação substancial dos procedimentos ocorreu no âmbito da Rodada Uruguai (1986-1994), com a adoção da Decisão de 1989. Esta decisão estabeleceu um sistema específico de solução de controvérsias a ser aplicado, sem prejuízo da Decisão de 1966 no que respeita às controvérsias entre países em desenvolvimento e países desenvolvidos (parágrafo A.4), para fins de exame de seus efeitos.

A Decisão de 1989 previa os seguintes procedimentos: consultas, bons ofícios, conciliação e mediação voluntários, intervenção das Partes Contratantes ou arbitragem. Tal como estabelecido pelo Entendimento de 1979, as Partes Contratantes poderiam estabelecer um grupo de trabalho ou painel em cujo relatório baseariam sua decisão, conforme a solicitação da parte contratante demandante.

Dentre as novidades previstas por esta decisão, facultou-se às partes da controvérsia o recurso ao procedimento de arbitragem para solução de sua controvérsia (parágrafo E.2), cujo laudo se comprometiam a respeitar (parágrafo E.3). Ademais, previuse a possibilidade de ocorrência simultânea dos bons ofícios e do painel ou grupo de trabalho (parágrafo D.2).

De acordo com o parágrafo A.3, o sistema criado pela decisão deveria ser aplicado no período que abrange de $1^{\circ}$ de maio de 1989 até o fim da rodada, com o fím de verificar sua aplicação prática e decidir sobre sua adoção até seu prazo de expiração. A Decisão de 22 de fevereiro de 1994 na Extensão da Decisão de Abril de 1989 sobre os aprimoramentos das Regras e dos Procedimentos do GATT sobre Solução de Controvérsias manteve o sistema até a entrada em vigor da OMC.

Por fim, observa-se que, nas primeiras sessões das Partes Contratantes, as atividades administrativas eram desempenhadas pelo Comitê Executivo - cujas regras de procedimento foram definidas pelo documento ICITO (ICITO/EC.1/3) - responsável pela condução das negociações da própria OIC. Não havia, contudo, uma institucionalização de

\footnotetext{
${ }^{6}$ Descrições detalhadas dos procedimentos em cada código encontram-se disponíveis em R. E. HUDEC (1980) e USITC (1985).
} 
tal órgão, de modo que as controvérsias deveriam ser apresentadas durantes as sessões das Partes Contratantes, que ocorriam, tal como disposto pelo GATT-1947, duas vezes ao ano, pelo menos.

Em 1960, em razão das dificuldades derivadas desta restrição, iniciou-se discussão sobre a criação de um órgão que se reunisse com mais freqüência para desempenhar as atividades das Partes Contratantes ${ }^{97}$. Como resultado das conversações, foi criado o Conselho, cuja primeira reunião foi realizada entre 19 e 23 de setembro de 1960 em Genebra ${ }^{98}$, para cumprir as obrigações das Partes Contratantes com maior periodicidade. Neste sentido, as referências a Partes Contratantes nos instrumentos acima citados passam a incluírem também o Conselho.

\subsubsection{OMC}

Com a entrada em vigor da OMC, o sistema de solução de controvérsias desta organização passou a ser regido pelo Entendimento sobre Solução de Controvérsias, o qual declara que os membros reconhecem sua adesão aos princípios de administração de controvérsias aplicados com base nos artigos XXII e XXIII do GATT-1947 99.

Não obstante, o sistema estabelecido pelo Entendimento sobre Solução de Controvérsias assemelha-se, mas não se confunde, apenas com aquele criado pela Decisão de 1989. Além da criação da própria organização, uma das diferenças em relação ao

\footnotetext{
${ }^{97}$ Os documentos resultantes da discussão são os seguintes: GATT (L/1200) e GATT (L/1216).

${ }^{98}$ A minuta da reunião encontra-se no documento GATT (C/M/1).

99 Sobre a relação entre o GATT-1947 e o GATT-1994, v. E. UlRICH-PETERSMANN (1998:50-51): “This method of making the new 'GATT 1994' legally distinct from the old 'GATT 1947' was part of the strategy to exclude 'free-riding' and to replace the old GATT by a new WTO. (...) This termination of the GATT 1947 at the end of 1994 (with effect from the end of 1995), and the GATT 'waivers' granted in this decision enabling GATT member countries to limit the benefits under the WTO AG to WTO members, entailed another threat against 'free-riders': the contracting parties of GATT 1947 were faced with the choice of either joining the WTO Agreement or of finding themselves outside the world trading system without legally secure access to foreign markets. Notwithstanding the legal separation and termination of the GATT 1947, the GATT provisions, and the legal instruments and decisions adopted by the GATT Contracting Parties, were incorporated into the 'GATT 1994' by reference in Annex 1A of the WTO Agreement. This legal continuity is also reflected in many other WTO provisions. For example, Art. IX of WTO AG enjoins the WTO to 'continue' the practice of decision-making by consensus followed under GATT 1947'. And Article 3 of the WTO's DSU affirms the members' 'adherence to the principles for the management of disputes heretofore applied under Arts XXII and XXIII of GATT 1947, and the rules and procedures as further elaborated and modified herein"'.
} 
sistema anterior consiste na criação do OSC, ao qual cabe a administração das normas do referido entendimento (artigo 2.1) e a decisão da controvérsia, quando solicitado (artigo 16). Assim, ao contrário do que ocorria no GATT-1947, cabia às Partes Contratantes manifestação sobre todos os assuntos do sistema; na OMC, o OSC é um órgão especializado em solução de controvérsias.

Com relação às fases pelas quais passa, ou pode passar, uma controvérsia surgida no âmbito da OMC, o Entendimento sobre Solução de Controvérsias prevê as seguintes: consultas, bons ofícios, conciliação, mediação, arbitragem, intervenção do OSC, ou recurso à Decisão de 1966.

Tal como ocorrera com a Decisão de 1989, a fase de consultas é obrigatória, enquanto os procedimentos voluntários de bons ofícios, conciliação e mediação podem ser realizados concomitantemente à intervenção do OSC. Houve alteração, contudo, nos órgãos que auxiliam o OSC no desempenho de suas atividades.

Deste modo, prevê-se apenas o estabelecimento de painel - ou seja, os grupos de trabalho não são previstos na normativa atualmente vigente - de cujo relatório o membro parte da disputa pode apelar para um Órgão de Apelação, ao qual compete se manifestar sobre os aspectos legais do referido relatório exclusivamente. Ainda é possibilitado às partes da controvérsias optarem pela arbitragem, caso seja de seu interesse (artigo 25). Observa-se que a negociação de solução mutuamente acordada é possível a qualquer momento dos procedimentos.

\subsection{Delegação de autoridade nos procedimentos de solução de controvérsias}

Tal como explanado no item 1.3 acima, o fator delegação de autoridade em um processo de juridicização é composto, no que se refere a mecanismos de solução de controvérsias, pelos seguintes elementos: acesso, independência e efeitos da decisão. A seguir os procedimentos de solução de controvérsias previstos ao longo da existência do sistema multilateral de comércio (identificados nos itens 2.2.1.2 e 2.2.2) serão analisados a partir da perspectiva de cada um dos referidos elementos. 


\subsubsection{Acesso}

Como previamente explanado, a análise do acesso a mecanismos de solução de controvérsias deve levar em consideração os seguintes fatores: imputação da legitimidade ativa; condições para início dos procedimentos; participação de terceiros; e custos necessários para patrocínio da causa.

Com relação ao primeiro fator, imputação da legitimidade ativa, a redação dos artigos XXII e XXIII do GATT-1947, a qual prevaleceu até a criação da OMC, deixa claro que apenas as partes contratantes podem se utilizar dos recursos disponibilizados para solução de suas controvérsias.

Em nenhuma das decisões adotadas, posteriormente, houve modificação desta disposição. Ressalta-se, contudo, que, no caso específico da Decisão de 1966, apenas os países em desenvolvimento poderiam solicitar sua aplicação para reger suas disputas em face de países desenvolvidos. Observa-se que, embora fosse destinada aos países em desenvolvimento, até então, o acordo não definia quais das partes contratantes deveriam ser consideradas como tal ${ }^{100}$.

Esta posição é reiterada no Entendimento sobre Solução de Controvérsias, o qual, em seus dispositivos, utiliza o termo "membro" para definir os sujeitos que participam dos procedimentos ali previstos. Neste sentido, o artigo 1 do referido entendimento estatui que: The rules and procedures of this Understanding shall also apply to consultations and the settlement of disputes between Members concerning their rights and obligations $(\ldots)^{101}$.

Por sua vez, partes contratantes, no GATT-1947, ou membros, na OMC, de acordo com o artigo XXVI do GATT-1947 e o artigo XII do Acordo de Marraqueche, são Estados ou territórios aduaneiros autônomos.

No que se refere ao segundo critério, verifica-se que, ao longo da existência do sistema multilateral de comércio, as condições para se dar início formal aos procedimentos de solução de controvérsias foram alteradas. Este fator reveste-se de importância pelo fato

\footnotetext{
${ }^{100}$ A respeito da evolução do conceito de país em desenvolvimento e país desenvolvido no âmbito do sistema multilateral de comércio, v. A. AMARAL JR. et al (2006:18).

${ }^{101}$ Observa-se que o artigo 17.4 do Entendimento sobre Solução de Controvérsias determina que apenas as partes de uma controvérsia, e não as terceiras partes, podem apelar da decisão do painel.
} 
de, tanto no GATT-1947 quanto na OMC, o órgão a quem compete emitir decisão sobre a controvérsia, após instado a tanto, eram assembléias compostas pelos representantes de todos aqueles que as compõem.

No âmbito do GATT-1947, de acordo com o artigo 25 do acordo, as Partes Contratantes eram compostas pelos representantes de todas as partes contratantes (no Gráfico 1 encontra-se ilustrada a evolução do número de partes do GATT-1947 e da $\mathrm{OMC})$.

As Partes Contratantes deveriam deliberar e aprovar o procedimento a que se deveria dar início em cada disputa de acordo com sua regra de tomada de decisão. Isto ocorreu desde a intervenção do presidente das Partes Contratante até o estabelecimento dos painéis resultantes da Rodada Tóquio ou da Decisão de 1989.

De acordo com o artigo XXV:4 do GATT-1947, as decisões adotadas pelas Partes Contratantes deveriam ser aprovadas pela maioria de seus votos. $\mathrm{Na}$ prática, contudo, as decisões eram adotadas por consenso entre todos os seus participantes (FoOTER:2005). Deste modo, para que um painel ou grupo de trabalho pudesse ser estabelecido fazia-se necessária a concordância daquele que era demandado na controvérsia.

Com relação a este ponto, R. E. HUDEC (1980:171) observa:

"According to GATT practice, the GATT Council had to authorize the creation of a panel in each case. The normal practice of the Council was to act by consensus, thus requiring the consent of the defendant government. Consent had the virtue of giving panel adjudication much the same character as a voluntary submission to arbitration, a useful advantage in securing acceptance of the eventual ruling. But the price of such consent was a series of opportunities for obstruction."

O parágrafo $5^{\circ}$ da Decisão de 1966 restringiu, de certa forma, esta característica do processo, ao determinar que: "Upon receipt of the report, the CONTRACTING PARTIES or the Council shall forthwith appoint a panel of experts to examine the matter with a view to recommending appropriate solution". Recorda-se, contudo, que esta decisão poderia ser utilizada apenas por países em desenvolvimento em face de países desenvolvidos. 
O próximo movimento no sentido de restringir a possibilidade que o demandado tinha de bloquear o início dos procedimentos de análise da disputa foi verificado ao fim da Rodada Tóquio, quando os códigos previam o direito de estabelecimento automático de um painel ${ }^{102}$. Ressalta-se, contudo, que, apesar de tal disposição, apenas o Código sobre Subsídios dispensava a autorização formal de seu comitê para que o painel fosse criado, pois estipulava que o painel deveria ser estabelecido 30 dias após o requerimento. Os demais códigos não se manifestavam quanto a isto, razão pela qual se supunha que a regra do Entendimento de 1979 deveria ser aplicada, ou seja, criação 30 dias após decisão das Partes Contratantes neste sentido (HUDEC, 1980:174).

No âmbito da OMC, o Entendimento sobre Solução de Controvérsias determina que o OSC, composto por todos os membros da organização, é competente para emitir uma decisão sobre as controvérsias que lhe são apresentadas. Não obstante, o artigo 6 do referido entendimento estipula regra diversa ao determinar que, mediante solicitação do membro demandante, um painel deva ser estabelecido, o mais tardar, na reunião seguinte àquela em cuja agenda aparecer, pela primeira vez, o pedido de estabelecimento do painel. Isto não ocorrerá apenas se o OSC decidir por consenso não o fazer.

Por sua vez, a participação de terceiros na controvérsia tem dois aspectos que devem ser considerados: as terceiras partes que participam do procedimento estabelecido e a intervenção de terceiros que não fazem parte de tais procedimentos por meio de, por exemplo, apresentação de amicus curiae ${ }^{103}$.

No que se refere à participação de terceiras partes, os documentos adotados ao fim da Rodada Tóquio foram os primeiros a formalizarem-na. Até então, não havia um direito de participação reconhecido formalmente.

Nota-se, contudo, que, durante a fase em que prevaleceram os grupos de trabalho, a participação de terceiras partes teve papel fundamental no desenvolvimento

\footnotetext{
${ }^{102}$ R. E. HUDEC (1980:183) observa: "If drafting decisions may be taken as a reliable indication of intention, the intentions of the Tokyo Round negotiators were fairly clear. They were willing to grant open and effective access to the panel procedure under the NTB codes, but wanted to keep a restraining hand on access under Article XXIII. The reason for the distinction seems obvious. The NTB codes were newly-drafted obligations that represented a current consensus about what could and should be done in the narrow subject are as to which they applied. The GATT obligations adjudicable under Article XXIII, on the other hand, contained a much wider and more varied set of rules, a number of which were questionable or obsolete".

${ }^{103}$ Nesta pesquisa, consideram-se amicus curiae as manifestações escritas elaboradas por sujeitos que não são nem partes nem terceiras partes da disputa. Em geral, são entidades não estatais que apresentam os amicus curiae ao OSC no curso de um determinado caso a respeito de algum ponto da controvérsia.
} 
rumo à emissão de relatórios mais neutros e na indicação futura de painéis (HUDEC, 1998). De fato, os grupos de trabalho eram compostos pelas partes da controvérsia e outras partes contratantes que tivessem interesse na questão - num total de entre 5 e 20 integrantes - e negociavam, conjuntamente, uma solução para a controvérsia (GATT: MTN/SG/W/8,2).

Com o início da fase de painéis, o procedimento foi modificado e as terceiras partes não mais compunham a negociação, mas passavam a ser ouvidas, em sessão específica, pelos painelistas chamados a comporem o painel cujo relatório embasaria a decisão das Partes Contratantes sobre a controvérsia (GATT:L/392,2).

No ínterim até o fim da Rodada Tóquio, a preocupação com o interesse das terceiras partes foi manifestada entre 1955 e 1958, com a adoção de regras que buscavam atribuir maior transparência às consultas e aos dados trocados ao longo das controvérsias (USITC:1985,19).

O Entendimento de 1979, por sua vez, facultava o estabelecimento de grupos de trabalho ou de painéis. Com relação aos primeiros, o referido documento estipulava que era aberta a participação para qualquer parte contratante que tivesse interesse na questão analisada (parágrafo 6(i) do Anexo).

Quanto aos painéis, o Entendimento estabelecia que toda parte contratante que tivesse interesse substancial no assunto trazido ao conhecimento do painel, após notificar o Conselho, tinha o direito de ser ouvida pelo painel (parágrafo 15). No mesmo sentido, em caso de eventual solução mutuamente acordada pelas partes da controvérsias, as terceiras partes poderiam inquirir sobre o seu conteúdo (parágrafo 19).

A Decisão de 1989 vai além e determina que os interesses de outras partes contratantes também devem ser levados em consideração no processo do panel (parágrafo $\mathrm{F}(\mathrm{e}) 1$ ). Ademais, reconhece às terceiras partes o direito de apresentação de petições, cujo conteúdo deve ser refletido no relatório pelo painel (parágrafo $F(e) 2$ ), e de acesso às petições apresentadas pelas partes da controvérsia, desde que consentissem (parágrafo $\mathrm{F}(\mathrm{e}) 3)$.

Esta restrição ao acesso a determinados documentos foi alterada pelo Entendimento sobre Solução de Controvérsias, cujo artigo 10 regulamenta os direitos das terceiras partes. De acordo com este instrumento, além das disposições da Decisão de 1989, as terceiras partes têm o direito de receber as petições apresentadas pelas partes da controvérsia para a primeira audiência entre as partes. 
O outro dispositivo relativo à intervenção de terceiros consiste na regulamentação do recebimento de amicus curiae pelos painéis e/ou pelo Órgão de Apelação. A princípio, o Entendimento sobre Solução de Controvérsias não se manifesta sobre a recepção de amicus curiae de entes que não são parte ou terceira parte da controvérsia. Deste modo, a questão acabou por ser desenvolvida pelas decisões emanadas dos painéis ou Órgão de Apelação.

O primeiro caso no qual se discutiu amplamente este tema foi o EUA-Camarões. Neste caso, diversas ONGs apresentaram amicus curiae, que em sua maioria foram rejeitados pelo painel, com base no artigo 13 do Entendimento sobre Solução de Controvérsias, referente à busca de informações pelos painelistas. Esta questão chegou ao conhecimento do Órgão de Apelação, o qual, a partir de paralelo entre procurar e não procurar, de um lado, e aceitar e não rejeitar, de outro, concluiu que:

"That the Panel's reading of the word 'seek' is unnecessarily formal
and technical in nature becomes clear should an 'individual or
body' first ask a panel for permission to file a statement or a brief.
In such an event, a panel may decline to grant the leave requested.
If, in the exercise of sound discretion in a particular case, a panel
concludes inter alia that it could do so without 'unduly delaying the
panel process', it could grant permission to file a statement or a
brief, subject to such conditions as it deems appropriate. The
exercise of the panel's discretion could, of course, and perhaps
should, include consultation with the parties to the dispute. In this
kind of situation, for all practical and pertinent purposes, the
distinction between 'requested' and 'non-requested' information
vanishes" (WT/DS58/AB/R, §107).

Diante de tal atitude, alguns membros da OMC protestaram, pois acreditavam que com tal decisão seriam conferidos mais direitos aos atores não institucionalizados do que a eles próprios, uma vez que apenas os membros que tivessem notificado sua decisão de participar do caso como terceira parte teriam o direito de apresentar documentos.

No caso United States - Imposition of Countervailing Duties on Certain HotRolled Lead and Bismuth Carbon Steel Products Originating in the United Kingdom (DS138), o Órgão de Apelação deixou claro que não tem o dever de receber nenhum documento de terceiros à organização, mas que ele tem autoridade, segundo o Entendimento sobre Solução de Controvérsias, para decidir receber ou não (OMC:WT/DS138/AB/R). 
No caso DS135: European Communities - Measures affecting asbestos and products containing asbestos (DS135), pela primeira vez, o Órgão de Apelação declarouse aberto ao recebimento de amicus curiae de fontes interessadas. Para tanto, fundamentou sua decisão no artigo 16(1) dos Procedimentos de Trabalho da Revisão de Apelação $(\mathrm{WT} / \mathrm{AB} / \mathrm{WP} / 3)$.

Tal como observa por P. MAVROIDIS (2001), embora o Entendimento sobre Solução de Controvérsias reconheça a possibilidade de recebimento de documentação não requisitada pelos painéis (artigo 13), nem painéis nem Órgão de Apelação têm a obrigação de notificar seu recebimento, discuti-los e nem sequer arrolá-los em seus relatórios. Como resultado da falta de transparência, não é possível determinar, com precisão, o número e a origem dos amicus curiae recebidos ao longo dos procedimentos ${ }^{104}$.

No que se refere ao último aspecto da análise de acesso a mecanismos de solução de controvérsias, custos, até a conclusão desta dissertação, não haviam sido encontradas pesquisas específicas que comprovassem e relacionassem a média do GATT-1947 com a da OMC. Os dados apresentados nesta pesquisa, portanto, em sua maior parte, foram deduzidos da descrição dos procedimentos.

Nas controvérsias em que o presidente das Partes Contratantes interveio e nos grupos de trabalho, por exemplo, os representantes das partes da controvérsia participavam com o intuito de negociar a solução a partir de sua experiência na própria negociação do acordo. Deste modo, não preparavam documentos a serem apresentados para defesa de seus pontos - até mesmo porque participavam da redação do relatório a ser emitido, de modo que, a qualquer momento, poderiam retificar eventuais incorreções ou preencher lacunas.

A partir do estabelecimento de painéis, contudo, passou a ser necessária a preparação de documentos que oferecessem aos painelistas os argumentos defendidos pelas partes da controvérsia. Isso porque não teriam chance de participar da redação do relatório

\footnotetext{
${ }^{104}$ M. R. SANCHEZ (2004) procede, em sua tese de doutoramente, a levantamento de todos os amicus curiae que foram apresentados nas diversas disputas na $\mathrm{OMC}$, a partir dos relatórios da disputas e das informações disponibizadas pelos próprios redatores, e à avalição da questão.
} 
a ser emitido ${ }^{105}$ - ainda que uma versão prévia e resumida lhes fosse apresentada, conforme descrito no item 2.3.2.2 abaixo.

A preparação prévia da fundamentação da defesa das partes numa controvérsia passou a ficar mais evidente na década de 1970. Como observa R. E. HuDEC (1980:184): "Recent panel decisions indicate that legal counsel is involved in the disputes. The parties seem to raise and thoroughly contest every possible legal argument. More ominously, lawyers seem to be drafting the complaints" ${ }^{\prime 106}$. O mesmo autor esclarece que, a partir de então, as disputas iniciadas pelo governo dos EUA são elaboradas por uma equipe de advogados do United States Trade Representative (USTR), que utiliza técnica de argumentação diferenciada (HUDEC:1998,111):

"In the tradition of much US domestic litigation, the US legal claims typically presented every legal argument that could be lodged against the trade measure being atttacked, ocassionaly including many of rather dubious merit. In the GATT legal proceedings that followed, each of the many legal arguments was typically pressed as forcefully as possible, obliging panels to work their way through a sometimes bewildering array of not-alwaysconsistent legal theories. The author has sometimes referred to this style of legal argumentation as carpet bombing - the military term for saturating a target with the largest possible number of bombs that can be dropped on or near it."

Ora, os EUA eram uma das partes contratantes que mais utilizava o sistema de solução de controvérsias, de modo que, mesmo apesar de as demais partes ainda desejarem defender suas posições tal como o faziam até então, seria necessário prepararem-se para responder aos argumentos apresentados por aquele país.

No âmbito da OMC, a questão relativa aos custos para patrocínio de uma demanda fica evidente nas discussões da Rodada Doha sobre modos de superação da falta de capacitação técnica dos países em desenvolvimento para participarem do mecanismo de

\footnotetext{
${ }^{105}$ Cf. USITC (1980: 16): "Because the parties were not present at the decision making stage under this new approach, they were forced, as a practical matter, to organize their cases and put their arguments in writing to ensure that the relevant facts and arguments would be before the panel at the time of decision".

${ }^{106} \mathrm{O}$ autor continua: "Lawyers vary, but tend to be more litigious than diplomats. The particular danger is that lawyers, because of their technical expertise, may come to exercise an influence over proceedings out of proportion to their knowledge of GATT affairs".
} 
solução de controvérsias da organização ${ }^{107}$. De fato, a prática demonstra que, na maioria, se não na totalidade dos casos, há a participação de algum tipo de consultoria.

Há estimativas de que a consultoria contratada para um caso mais complexo possa chegar a custar até US\$12 milhões ${ }^{108}$ - o que independe do fluxo de comércio do bem afetado pela medida questionada, por exemplo. Isto acaba por ser um custo alto para grande parte dos membros da OMC, que são países em desenvolvimento.

De fato, V. Mosoti (2003:14) reconhece que os custos são um dos fatores que determinam a baixa participação dos países em desenvolvimento no OSC:

"The DS is complicated and expensive. Developing country Members need time to continually train domestic lawyers in the WTO disciplines and the practice of dispute settlement, to a level that would be equal or comparable to the legal skills at the easy disposal of developed Members. The participation of developing and least developed Members in the DS has been minimal due to the lack of adequate and skilled trade lawyers. Any little success they have had in the DS has been severely constrained and ultimately at a heavy cost, adversely straining their scarce resources. They have had to incur huge expenses resulting from the hiring of very expensive private lawyers. Some of these problems have been commendably solved to a degree by the existence of the recently inaugurated Advisory Centre on WTO Law (ACWL). Some challenges, such as the training of a cadre of local trade lawyers will persist for a long time to come, and perhaps only can be resolved through concerted efforts at regional levels, with the assistance of the ACWL, the WTO Training Institute and such other bodies."

Numa tentativa de superar tal obstáculos, os membros reuniram-se, fora da organização, para criar uma entidade que lhes prestaria assessoria a valores mais acessíveis. Deste modo, foi criado o Advisory Centre on WTO Law (ACWL) ${ }^{109}$ - o qual, no entanto, não faz parte da OMC e depende, portanto, de filiação própria.

\footnotetext{
${ }^{107}$ A discussão encontra-se detalhada e avaliada, a partir de uma perspectiva brasileira, em A. AMARAL JR. et al (2006: 65).

${ }^{108}$ Cf. C. CARDOSO (2005).

109 A página eletrônica oficial do ACWL encontra-se acessível a partir de: $<$ http:// www.acwl.ch>. Neste endereço, é possível acessar também seu documento de criação, lista de membros e os valores cobrados pelos serviços prestados.
} 


\subsubsection{Independência}

Com relação ao fator independência, verifica-se sua conformação a partir da análise de três aspectos: a independência subjetiva, a independência decisória e a independência financeira.

\subsubsection{Subjetiva}

A fim de determinar o nível de independência subjetiva de um determinado mecanismo, faz-se necessário verificar como se desenvolve o processo de escolha daqueles a quem compete emitir uma decisão sobre a controvérsia. Nesse sentido, busca-se identificar o nível de interferência das partes da controvérsia em sua escolha e as características de seu mandato.

No que se refere ao primeiro fator, observa-se que, tanto na primeira fase dos procedimentos de solução de controvérsias do GATT-1947 (intervenção do presidente das Partes Contratantes) quanto no período em que foram organizados grupos de trabalho, o procedimento mais se assemelhava à negociação entre as partes da controvérsia. Isso porque o resultado da demanda dependia, diretamente, daquilo que era definido pelas partes em composição direta.

De acordo com GATT (L/392:1-2), o número de integrantes dos grupos de trabalho dependia do nível de importância da medida discutida - em geral, entre 5 e 20 delegações, cujos representantes eram por elas mesmas indicados. Dentre os integrantes, incluíam-se as partes da controvérsia e aquelas partes contratantes que alegavam ter interesse na questão. Todos os participantes tinham o mesmo status (GATT: $\mathrm{MTN} / \mathrm{SG} / \mathrm{W} / 8,2)$.

$\mathrm{Na}$ fase de estabelecimento de painéis para sessão, por sua vez, as partes da controvérsia não mais fazem parte do painel (GATT:L/392,2), cuja composição era indicada pelo presidente das Partes Contratantes, a partir da negociação em cada sessão com as partes contratantes ${ }^{110}$.

\footnotetext{
${ }^{110}$ V., por exemplo, nota de rodapé 84 acima.
} 
A partir da indicação de painéis ad hoc, contudo, consolida-se a indicação de indivíduos para sua composição. A princípio, os painéis eram compostos por número variável de indivíduos de países não diretamente afetados pelas medidas questionadas - em geral,entre 3 e 5 (GATT:MTN/SG/W/8,3). A indicação deveria ser realizada com base em critérios de conhecimento do assunto tratado e diversidade de origem, e sua composição final dependeria da aprovação das partes da controvérsia e das Partes Contratantes (parágrafo 6(ii) do Anexo ao Entendimento de 1979).

A Decisão de 1966, por sua vez, determinava, expressamente, que a indicação do painel deveria ser realizada pelas Partes Contratantes (parágrafo 5). Como se tem conhecimento de apenas uma disputa em que tal decisão foi argüida, disputa esta em que não se estabeleceu um painel, não é possível verificar a prática.

Com relação aos documentos adotados na Rodada Tóquio, no entanto, o Entendimento de 1979 determinava que o Diretor Geral (ou seja, do Secretariado) faria a indicação da composição do painel, após consultas com as partes da disputa, e a submeteria à aprovação das Partes Contratantes (parágrafo 11). O parágrafo 12 do Entendimento de 1979, contudo, ressaltava que as partes da controvérsia poderiam recusar a indicação dos painelistas apenas quando houvesse compelling reasons para tanto.

O mesmo parágrafo, expressamente, determina que se dê preferência a representantes governamentais na composição dos painéis, embora estes indivíduos devessem agir em sua capacidade pessoal e não em nome de seus governos (parágrafo 14). Além disso, a composição deveria representar diversidade de formação e origem, sendo que, nos casos entre países em desenvolvimento e países desenvolvidos, dever-se-ia buscar a inclusão de, pelo menos, um painelista originário de país em desenvolvimento.

A partir deste documento, determinou-se que caberia ao Diretor Geral a elaboração e a administração de uma lista informal de indivíduos, do governo ou não governamentais, qualificados em relações comerciais, desenvolvimento econômico e outros temas compreendidos pelo GATT-1947, que pudessem participar da composição dos painéis (parágrafo 13). Tal lista seria preparada a partir das indicações apresentadas pelas próprias partes contratantes no início de cada ano.

Observa-se, contudo, que, na prática, apenas em 1981, passam a ser inseridas nos relatórios financeiros elaborados pelo Secretariado, menções com despesas de viagens de painelistas. Este fato indica que, até então, os painelistas encontravam-se em Genebra 
mesmo. De fato, o parágrafo 6(ii) do Anexo ao Entendimento de 1979 reconhece que os painelistas costumavam indicados dentre os membros das delegações permanentes das partes contratantes em Genebra.

A Decisão de 1982, por sua vez, reitera o compromisso das partes contratantes com a elaboração da lista de indicações para painelistas. No mesmo sentido, mas de forma mais específica, a Decisão de 1984 determina que as partes contratantes deveriam indicar ao Diretor Geral os nomes de indivíduos qualificados para atuar como painelistas que não fossem parte de seus governos, mas tivessem grande conhecimento de comércio internacional e experiência no GATT (parágrafo 1). A partir destas indicações, as Partes Contratantes, em consulta com o Diretor Geral, elaborariam uma lista que serviria para escolha dos painelistas em cada caso.

Também a Decisão de 1984 declara que se deve dar preferência, na composição dos painéis, aos representantes governamentais. Nos casos em que não fosse possível a composição dos painéis em até 30 dias a partir de sua solicitação, o Diretor Geral, com base na lista de representantes não governamentais, complementaria os nomes faltantes.

A Decisão de 1989, por sua vez, também retoma a lista de possíveis painelistas não governamentais e determina que os painéis devem ser compostos por representantes governamentais e não governamentais qualificados (parágrafo 2). Desta feita, incluiu-se o requisito de que as partes contratantes também forneçam informações relevantes sobre o conhecimento sobre comércio internacional e GATT dos indivíduos que indicassem.

Com relação ao número de painelistas, a Decisão de 1989 determina que os painéis sejam compostos por três indivíduos, salvo se houver concordância entre as partes da disputa, em até dez dias do estabelecimento do painel, de que este será composto por cinco indivíduos (parágrafo 4).

Esta disposição é encontrada também no Entendimento sobre Solução de Controvérsias, cujo artigo 8.1 estipula as qualidades daqueles que podem ser indicados como painelistas:

"Panels shall be composed of well-qualified governmental and/or non-governmental individuals, including persons who have served on or presented a case to a panel, served as a representative of a Member or of a contracting party to GATT 1947 or as a representative to the Council or Committee of any covered 
agreement or its predecessor agreement, or in the Secretariat, taught or published on international trade law or policy, or served as a senior trade policy official of a Member".

O Entendimento sobre Solução de Controvérsias também estabelece que, salvo disposição em contrário entre as partes, nacionais das partes da controvérsia ou terceiras partes não podem participar da composição do painel (artigo 8.3). Ademais, a composição dos painéis deve assegurar a independência de seus integrantes e ser representativa em termos de formação e experiência (artigo 8.2).

O referido documento também determina que o Secretariado tem o dever de manter uma lista indicativa a partir da qual serão selecionados os painelistas. Em tal lista serão identificadas as áreas de expertise específicas de cada indivíduo (artigo 8.4). Costuma-se questionar, contudo, o grau de observância da regra de escolha dos painelistas com base na referida lista.

No que se refere à composição dos painéis, o Entendimento sobre Solução de Controvérsias determina que, na falta de acordo em até 20 dias de seu estabelecimento, o Diretor Geral, em consulta com o presidente do OSC e do comitê respectivo, deverá indicar aqueles painelistas que julga apropriados para a disputa.

$\mathrm{O}$ entendimento, ainda, declara que os membros da $\mathrm{OMC}$ devem permitir que seus delegados participem dos painéis quando indicados (parágrafo 8.8), os quais atuarão em sua capacidade pessoal (artigo 8.9).

Enquanto os painelistas são indicados caso a caso, o Órgão de Apelação é composto por sete membros (artigo 17.1) cujo mandato se estende por quatro anos (artigo 17.2). A determinação dos membros que tomarão conhecimento de cada apelação apresentada ao órgão é estipulada nas regras de procedimento por ele formulada.

De acordo com o parágrafo 3 do artigo 17, o Órgão de Apelação deve ser composto por pessoas de reconhecida autoridade e com experiência comprovada em direito e comércio internacional, bem como ter conhecimento geral sobre os acordos abrangidos. Além disso, não podem fazer parte de nenhum governo, e sua composição deve representar a diversidade dos membros da OMC.

Observa-se, portanto, que, enquanto, no GATT-1947, não havia a formalização de um órgão que assessorasse as Partes Contratantes no desempenho de suas funções 
derivadas dos artigos XXII e XXIII; na OMC, há a institucionalização do Órgão de Apelação, ainda que a indicação dos painéis seja ad hoc e para cada caso em específico.

A estrutura do GATT-1947 e da OMC encontra-se ilustrada nos Apêndices A e $\mathrm{B}$, respectivamente.

\subsubsection{Decisória}

A análise do nível de independência decisória imputada a um determinado mecanismo de solução de controvérsias busca avaliar os seguintes fatores: amplitude da jurisdição que lhe é atribuída e possibilidade de as partes da controvérsia interferirem diretamente no conteúdo da decisão.

No que se refere ao primeiro critério, amplitude da jurisdição, o artigo XXIII:2 do GATT-1947 determina que: "the CONTRACTING PARTIES shall promptly investigate any matter so referred to them and shall make appropriate recommendations to the contracting parties which they consider to be concerned, or give a ruling on the matter, as appropriate". Observa-se, portanto, que sua redação não restringia as fontes que poderiam ser utilizadas pelas Partes Contratantes para fundamentarem sua decisão.

$\mathrm{Na}$ prática, como demonstrado acima, as Partes Contrantes dependiam de relatório elaborado por outro órgão para emitirem sua decisão. A jurisdição destes órgãos auxiliares, contudo, era determinada pelos termos de referência específicos.

O parágrafo 6(i) do Anexo do Entendimento de 1979 reconhece que os termos de referência dos grupos de trabalho eram, em geral, os seguintes: to examine the matter in the light of the relevant provisions of the General Agreement and to report to the Council.

Por sua vez, os termos de referência dos painéis para sessão (GATT: $\mathrm{MTN} / \mathrm{SG} / \mathrm{W} / 8$ ) costumavam seguir o seguinte modelo, na prática:

To consider, in consultation with the representatives of the countries directly concerned ando $f$ other interested countries, complaints referred to the Contracting Parties under Article XXIII and such other complaints as the Contracting Parties may expressly refer to the Panel and to submit findings and recommendations to the contracting parties. 
Com relação aos painéis ad hoc, a princípio, seus termos de referência acompanhavam o seguinte modelo (GATT:MTN/SG/W/8), na prática:

Ad hoc Panels: to make such findings as will assist the CPs in making the recommendations or rulings provided for in paragraph 2 of Article XXIII.

A primeira formalização dos termos de referência foi realizada pela Decisão de 1989, a qual estatuiu que, salvo acordo em sentido diverso entre as partes da controvérsias, os termos de referência padrão deveriam ser os seguintes (parágrafo $F(b) 1)$ ):

"To examine, in the light of the relevant GATT provisions, the matter referred to the Contracting Parties by (name of contracting party) in document L/... and to make such findings as will assist the Contracting Parties in making the recommendations or in giving the rulings provided for in Article XXIII:2"'.

Por sua vez, o Entendimento sobre Solução de Controvérsias determina que os termos de referência padrão são os seguintes (artigo 7.1):

"To examine, in the light of the relevant provisions in (name of the covered agreement(s) cited by the parties to the dispute), the matter referred to the DSB by (name of party) in document ... and to make such findings as will assist the DSB [OSC] in making the recommendations or in giving the rulings provided for in that/those agreement(s)".

Embora a Decisão de 1982 não determinasse qual deveria ser a redação dos termos de referência, estipulava que estes deveriam ser formulados de forma a permitir uma decisão clara quanto à contravenção das disposições do GATT e/ou ao dano e prejuízo sofrido pelo demandante. Nos termos do parágrafo 16 do Entendimento de 1979, esta decisão deveria ser fundamentada, após revisão dos fatos, na aplicação das disposições do GATT e nos argumentos apresentados pelas partes da disputa.

A este respeito, um documento preparado pelo Secretariado (GATT, MTN/SG/W/8) durante a Rodada Tóquio, a pedido do grupo de negociação sobre salvaguardas, resume a natureza da decisão emitida:

"Under the General Agreement, not only breaches of obligations but also measures not conflicting with the General Agreement, and 
even the existence of "any other situation" permits recourse to Article XXIII procedures provided the measure or situation nullifies or impairs benefits accruing under the Agreement or the objectives of the Agreement. It should be noted however that there has been no Article XXIII case in which a contracting party has claimed that there was a nullification or impairment of the "objectives" of the agreement, and only one case in which the claim was based on a nullification or impairment resulting from "any other situation". (...)The GATT is the only agreement in which not only governmental actions but "any situation may give rise to a suspension of obligations. This broadens the scope of Article XXIII beyond disputes over governmental actions and gives this provision the character of an emergency clause permitting the suspension of obligations by the CONTRACTING PARTIES in situations in which the Agreements purposes or the negotiated balance of benefits cannot be realized".

Conclui-se, portanto, que os relatórios produzidos poderiam tanto determinar fatos, tal como uma comissão de inquérito, quanto avaliar uma violação das regras do GATT-1947.

Observa-se que, no caso das controvérsias entre países em desenvolvimento e países desenvolvidos, de acordo com a Decisão de 1966, os painéis deveriam analisar também os efeitos das medidas questionadas sobre o desenvolvimento econômico e o comércio do país em desenvolvimento.

O Entendimento sobre Solução de Controvérsias, por sua vez, estatui expressamente que "the Members recognize that it serves to preserve the rights and obligations of Members under the covered agreements, and to clarify the existing provisions of those agreements in accordance with customary rules of interpretation of public international law" (artigo 3.2). Deste modo, atribui-se expressamente a competência ao OSC para interpretar os acordos abrangidos.

Divergência entre as traduções nas três línguas oficiais da OMC, contudo, tornam ambígua a delimitação das regras de interpretação a serem utilizadas para fundamentação da decisão.

Neste sentido, a versão em francês do referido artigo declara:

"Les Membres reconnaissent qu'il a pour objet de préserver les droits et les obligations résultant pour les Membres des accords visés, et de clarifier les dispositions existantes de ces accords 
conformément aux règles coutumières d'interprétation $d u$ droit international public" (grifo da autora).

$\mathrm{Na}$ versão em espanhol, contudo, o termo consuetudinárias passa a ser interpretado de modo diverso:

"Los Miembros reconocen que ese sistema sirve para preservar los derechos y obligaciones de los Miembros en el marco de los acuerdos abarcados y para aclarar las disposiciones vigentes de dichos acuerdos de conformidad con las normas usuales de interpretación del derecho internacional público" (grifo da autora) $)^{111}$.

Por outro lado, o Órgão de Apelação, conforme o artigo 17.6 do Entendimento sobre Solução de Controvérsias, tem competência para receber apelações de conclusões legais presentes nos relatórios dos painéis.

Não obstante o reconhecimento da competência para interpretação dos acordos, disposição encontrada a partir do Entendimento de 1979 até o Entendimento sobre Solução de Controvérsias determina que as decisões não podem aumentar ou diminuir os direitos e obrigações das partes da disputa.

Com relação ao segundo aspecto da independência decisória, possibilidade de as partes da controvérsia interferirem diretamente no conteúdo da decisão, verifica-se que, apesar de a previsão de interferência direta tenha sido restringida ao longo da vigência do sistema multilateral de comércio, ainda existe a possibilidade de sua ocorrência.

Tal como afirmado previamente, o procedimento com intervenção do presidente das Partes Contratantes consistia em negociação entre as partes da controvérsia. De fato, dentre as três disputas em que o presidente das Partes Contratantes interveio, duas tiveram relatório, em que se afirmava, em até quatro linhas, a solução acordada ${ }^{112}$.

Do mesmo modo, os grupos de trabalho também permitiam a negociação direta entre as partes da disputa e os demais integrantes, de modo que seus relatórios buscavam

\footnotetext{
111 Esta versão parece ter influenciado a tradução para a língua portuguesa que foi incorporada ao ordenamento brasileiro, visto que persiste a diferença em relação às duas outras línguas: "Os Membros reconhecem que esse sistema é útil para preservar direitos e obrigações dos Membros dentro dos parâmetros dos acordos abrangidos e para esclarecer as disposições vigentes dos referidos acordos em conformidade com as normas correntes de interpretação do direito internacional público" (grifo da autora).

112 Os casos foram os seguintes: Application of Article I:1 to Rebates on Internal Taxes; e The Phrase "Charges of Any Kind" in Article I:1 in Relation to Consular Taxes.
} 
refletir o consenso alcançado em seu âmbito (GATT:MTN/SG/W/8]). De fato (GATT: L/392):

"the report of such a working party must either represent the views of all its numbers or record any minority views. Since the tendency has been to strive for unanimity, there has usually been some measure of negotiation and compromise between the consulting government and the rest of the working party in determining the form the report shall take".

Por outro lado, os relatórios dos painéis, sejam eles para sessão ou ad hoc, na medida em que procuravam consistir em análise mais neutra, eram redigidos sem a presença das partes da disputa. Nesse sentido, documento elaborado para revisão dos painéis para sessão (GATT:L/392) esclarece:

"After having heard the parties and any other contracting party
which might have an interest in the case, the members of the Panel
meet in closed session and arrive at their own conclusions. The
report is then drafted under their individual responsibility and does
not prejudice the attitude of the parties to the dispute. Nor does it
prejudice the later position that may be taken by governments
during the subsequent consideration of the report by the
CONTRACTING PARTIES. In practice the draft report is shown to
the parties immediately concerned before it is circulated. The
Panel meets again, with those parties and any other observers,
hears their comments, and finally meets to approve the text. The
report is then submitted to the CONTRACTING PARTIES and
discussed in the same manner as the report of an ordinary working
party".

A apresentação de uma versão interina do relatório para as partes da controvérsia era interpretada como uma forma de negociação, ainda que restrita (GATT:MTN/SG/W/8). O Anexo do Entendimento de 1979 - o qual reconhecia, expressamente, que os relatórios dos painéis eram redigidos na ausência das partes da controvérsia, à luz das declarações dadas (parágrafo A.6(vi)) - justifica a apresentação do relatório interino como uma tentativa de fazer as partes da controvérsia chegarem a solução mutuamente acordada.

A Decisão de 1982, por sua vez, determinou que, nos casos em que o relatório do painel aconselha as Partes Contratantes a emitirem uma decisão, pode estabelecer-se um 
prazo dentro do qual ele pode ser manifestar sobre a ação que as Partes Contratantes devem adotar.

Embora a Decisão de 1989 não dispusesse sobre a apresentação de um relatório interino para as partes da controvérsia, o Entendimento sobre Solução de Controvérsias prevê a realização de uma etapa intermediária de revisão (artigo 15). Em decorrência, após consideração das réplicas e apresentações orais, o painel deve apresentar para as partes da controvérsia um esboço dos capítulos do relatório que irá emitir (artigo 15.1).

Em seguida, depois de expirado o prazo para recebimento dos comentários das partes sobre o esboço, o painel distribuirá um relatório interino, no qual se incluem os capítulos descritivos e as conclusões, sobre os quais as partes da controvérsia terão nova oportunidade de se manifestar (artigo 15.2).

Por fim, o Entendimento sobre Solução de Controvérsias, por questão de transparência, determina que o relatório final deve refletir os argumentos apresentados nesta etapa (artigo 15.3). Observa-se que não há dispositivo semelhante para a fase de apelação.

\subsubsection{Financeira}

O nível de independência financeira de um mecanismo de solução de controvérsias pode ser avaliado a partir da determinação da origem da remuneração concedida aos decisores, da análise da infra-estrutura que lhes é disponibilizada e do meio de divulgação das decisões que dele emanam.

Com relação ao primeiro critério, remuneração dos decisores, observa-se que este critério passa a ser aplicável a partir da fase de estabelecimento de painéis, visto que nas duas fases anteriores, as próprias partes da disputa compunham o grupo.

Questões relativas à remuneração e gastos passam a ser incorporadas nos instrumentos do GATT-1947 a partir do Entendimento de 1979, o qual, em nota de rodapé, determina que os gastos com despesas de transporte devem respeitar os limites orçamentários do GATT-1947. No mesmo sentido, parágrafo iii da Decisão de 1982 determina que, quando não houver especialistas em Genebra, todas as despesas do painelista estrangeiro devem ser cobertas pelo orçamento do GATT-1947. 
Dentre os relatórios financeiros do GATT-1947, apenas em 1981, surge a primeira menção a gastos com o sistema de solução de controvérsias, sob a rubrica de despesas com viagens oficiais ${ }^{113}$. Em 1982, por outro lado, além de reiterar a disposição relativa a pagamento de viagens, o relatório também traz a previsão de custos alocados para o pagamento de especialistas que sejam chamados a participar nos painéis de solução de controvérsias a pedido de uma parte contratante ${ }^{114}$. As duas previsões são repetidas no relatório referente ao ano de $1983^{115}$.

Ao contrário do que ocorreu nestes três relatórios, em que estes gastos eram incluídos na seção de assistência temporária, a partir do relatório financeiro relativo ao ano de 1984, incluiu-se seção específica para as despesas com o sistema de solução de controvérsias (GATT:L/5520):

In accordance with the terms of the Declaration made at the Session of the Contracting Parties at Ministerial Level in November 1982, that a credit be made available for this purpose, a separate provision has been made for 1984 to cover fees, subsistence allowance and travel costs that it is anticipated will have to be paid in 1984 in respect of experts to serve on such panels coming from outside Geneva, if not provided for free of charge.

Após esta primeira experiência, o relatório referente ao ano de 1985 afirma (GATT:L/5700):

The provision to cover the cost of experts who are not selected from delegations in Geneva to serve on dispute settlement panels, has

\footnotetext{
${ }^{113}$ Cf. GATT (L/5020): "The provision has been increased by SwF 60,000 to enable the Director-General to comply with the terms of Article XXIII and of the MTN agreements in conexion with the establishment of ad hoc panels for the settlement of disputes, at the request of interested contracting parties. A roster of governmental and non-governmental experts is maintained for service on these panels and the provision is intended to cover travel costs and subsistence allowance for experts coming from outside Geneva". O mesmo documento traz, ainda, outra referência a painéis, mas, desta vez, com o objetivo de treinar especialistas que pudessem atuar neles, p. 3/4: "Bearing in mind that two additional MTN agreements (Codes on Custom Valuation ando $n$ Government Procurement) will enter into force in January 1981 and that negotiations on the future of the Multi-Fibres Arrangement will take place in 1981, the main features of the proposals are: (...) - to add a provision of $S w F$ 260,000 for professional and clerical assistance to cope with the preparation of dispute settlement panels and for experts to serve on them".

${ }^{114}$ Cf. GATT (L/5180): "The provision proposed for 1982 can be further analyzed (a) for consultants and other professional assistance as follows: (...) - experts to serve on dispute settlement panels at the request of interested contracting parties".

${ }^{115}$ Para disposições específicas, v. GATT (L/5350).
} 
been increased as experience in 1984 is demonstrating the inadequacy of the 1984 budget provisions for this purpose.

Disposição similar é encontrada no relatório de 1988, em que se chama a atenção para o aumento do número de casos apresentados e de painelistas chamados ${ }^{116}$. Relatórios posteriores não incluem o número de painelistas chamados, mas apenas o número de diárias pagas ${ }^{117}$.

Observa-se, portanto, que os painelistas que participavam dos painéis, no âmbito do GATT-1947, em geral, não eram remunerados por suas atividades. A partir dos dados dos relatórios financeiros preparados pelo Secretariado, apenas as despesas com transporte e subsistência eram incluídas.

Por outro lado, os painelistas e membros do Órgão de Apelação da OMC são remunerados por suas atividades e pelos gastos em que incorrem para desempenho de sua função (v. artigo 8.11). De fato, em proposta apresentada pelo Canadá, nas negociações da Rodada Doha sobre a reforma do Entendimento sobre Solução de Controvérsia, considerase baixa a remuneração que recebem em relação a outros órgãos internacionais ${ }^{118}$. Enquanto os painelistas são remunerados por caso de que participam.

No que se refere ao segundo aspecto da independência financeira, infraestrutura disponibilizada, na prática, o Secretariado ${ }^{119}$ responsabilizou-se pela assistência dos painelistas ao longo de todo o GATT-1947. A primeira menção formal a esta tarefa, contudo, ocorreu apenas na Decisão de 1982 (parágrafo iv).

\footnotetext{
116 Cf. GATT (L/6220): "an increase of SwF 100,000 is requested for the dispute settlement panels. Increasing use is being made of dispute settlement panels and of "outside panelists" (i.e., panelists who are not members of the Geneva delegations). As at $1^{\text {st }}$ september there have been 15 panels in operation since 1987 as compared to only 2 during 1986. So far this year, 9 outside painelists have been recruited, compared to 3 last year. These trends are expected to continue".

117 V., por exemplo, o relatório de 1989 (GATT:L/6390), o relatório de 1990 (GATT:L/6550), o relatório de 1991 (GATT:L/6850), o relatório de 1992 (GATT:L/6900), o relatório de 1993 (GATT:L/7070) e o relatório de 1994 (GATT:L/7300).

118 Cf. a proposta apresentada pelo Canadá no processo de negociação da Rodada Doha (WTO:TN/DS/W/41), os painelistas da OMC recebem diárias de CHF 600, em comparação com as médias diárias de outros órgãos internacionais que seriam, respectivamente: ICSID, CHF 2,772; London Court of International Arbitration (LCIA), CHF 2,503 - 5,842; International Centre for Dispute Resolution da American Arbitration Association (AAA), CHF 2,599 - 4,678; British Columbia International Commercial Arbitration Centre (BCICAC), CHF 1,687 - 4,159; Court of Arbitration for Sport (CAS), CHF 1,500; membros do tribunal do capítulo onze do North American Free Trade Agreement (NAFTA), CHF 3,639 4,678; e painelistas dos capítulos 19 e 20 do NAFTA, CHF 719.

${ }^{119}$ Em razão da não entrada em vigor da OIC, contudo, as Partes Contratantes decidiram pela criação de um secretariado específico para o GATT-1947, ainda que com estrutura restrita.
} 
Quando da adoção do GATT-1947, a atividade de Secretariado que lhe era necessária foi realizada pelo Comitê Interino da Organização Internacional do Comércio (ICITO, sigla em inglês), criado pela Resolução E/CONF.2/67 da Conferência das Nações Unidas sobre Comércio e Emprego (UNCTE, sigla em inglês), em 16 de março de 1948.

Neste período, as despesas necessárias para a consecução de seus objetivos eram liquidadas com recursos provenientes da ONU, os quais, a princípio, seriam ressarcidos quando da entrada em vigor da OIC. Na prática, contudo, como isto não ocorreu, as despesas foram ressarcidas ao longo dos anos pelas Partes Contratantes, a partir de programas elaborados pelo Secretário Executivo.

Não obstante a tarefa de assistência, como demonstrado no Apêndice A, o Secretariado do GATT-1947 começou a ter infra-estrutura direcionada a aspectos legais apenas a partir da década de 1980. Conforme explica R. E. HudEC (1998:114):

\begin{abstract}
"Arthur Dunkel replaced Olivier Long as Director-General of GATT in 1980, just as the number of problematic panel rulings was beginning to draw attention to the Secretariat's lack of legal expertise. To many Secretariat officials and GATT delegates, the answer seemed obvious - the Secretariat would have to acquire a staff of professional lawyers to advise panels. (...) Dunkel's response [para a oposição européia a tanto] was in the best traditions of the glacial gradualism that is typical of much GATT diplomacy. In January 1981, he created a Secretariat position entitled Director of Legal Affairs. (...) The two year experiment with the Director of Legal Affairs apparently caused no major problems for the Community. In the meantime, the volume and complexity of GATT litigation had grown even greater, making it all but essential that the Secretariat retain the position of legal advisor in some form or other.(...) it was possible to take a series of additional steps over the next six months that eventually strengthened the position considerably. First, the position lost its temporary character. The title of the position was changed to Director, Office of Legal Affairs, with the Office being a permanent part of the Secretariat. Soon afterwards, additional staff was added".
\end{abstract}

Observa-se que o artigo 27 do Entendimento sobre Solução de Controvérsias dispõe sobre as responsabilidades do Secretariado da OMC, no que se refere à solução de controvérsias. De acordo com o referido artigo, dentre outras funções, o Secretariado deve assessorar os painéis, em especial com relação a aspectos legais, históricos e 
procedimentais das matérias abordadas, além de prover os serviços administrativos que lhes sejam necessários.

No mesmo sentido, o artigo 17.7 do mesmo instrumento determina que os membros do Órgão de Apelação devem receber todo o apoio necessário para desempenho de suas funções.

Por fim, com relação ao meio de publicação das decisões, verifica-se que, no âmbito do GATT-1947, somente a partir de 1952, as Partes Contratantes criaram um meio oficial de publicação de seus documentos: o Basic Instruments and Selected Documents (BISD). Esta publicação incluía todos os documentos oficiais adotados no âmbito do GATT-1947 (REHBERG:2003). Neste sentido, os relatórios dos painéis adotados pelas Partes Contratantes eram publicados, enquanto os não adotados não o eram. Para acesso a estes documentos, dever-se-ia recorrer à biblioteca da organização.

A OMC detém corpo de publicação semelhante. Ademais, todos os documentos produzidos em seu âmbito são publicados de acordo com a regulamentação das regras relativas à transparência (OMC:WT/L/160/Rev.1) e, assim, disponibilizados na página eletrônica da organização. Os relatórios dos painéis e os do Órgão de Apelação, bem com os laudos arbitrais, também são disponibilizados na página eletrônica da OMC. Nota-se, no entanto, que o meio oficial de publicação destes relatórios é o Dispute Settlement Report, publicado pela Editora da Universidade de Cambridge anualmente.

\subsubsection{Efeitos da decisão}

O último fator a determinar o nível de juridicização consiste nos efeitos da decisão proferida para a disputa. Este fator é composto pela determinação de sua obrigatoriedade e de sua executoriedade, em específico, se ambas dependem da aprovação das partes da controvérsia para produzirem efeitos.

No que se refere à obrigatoriedade da decisão, conforme previsto no Artigo XXIII do GATT, as Partes Contratantes poderiam emitir recomendações, decisões ou autorizações para suspensão de concessões. Enquanto as recomendações não têm força vinculante, as decisões são obrigatórias. 
Para análise da obrigatoriedade da decisão emanada das Partes Contratantes no âmbito do GATT-1947, faz-se imprescindível a referência à regra de tomada de decisão por consenso apresentada no item 2.3.1 acima. Neste sentido, ressalta-se que as decisões, para que fossem obrigatórias, deveriam ser adotadas por consenso entre todas as partes contratantes, dentre as quais se encontravam as próprias partes da controvérsia.

Esta regra prevaleceu ao longo de toda a vigência do GATT-1947. De acordo com E. P. EICHMANN (1990-1991:73), contudo, houve momentos em que se tentou alterála. Neste sentido, durante as negociações da Decisão de 1984 e da Decisão de 1989 surgiu debate relativo à adoção de um consensus minus, por meio do qual o demandado seria excluído da votação. A proposta não foi aprovada em nenhum dos dois momentos. $\mathrm{O}$ resultado mais próximo foi a inclusão, nos textos de ambas as decisões, da afirmação de que, embora a regra do consenso fosse mantida, ela não deveria prejudicar os procedimentos de solução de controvérsias.

No âmbito da OMC, contudo, o artigo 16.4 do Entendimento sobre Solução de Controvérsias determina a regra do consenso negativo, ou seja, o relatório somente não será aprovado se houver consenso entre os membros do OSC neste sentido. Em outras palavras, seria necessário que parte vencedora concordasse com a não adoção do relatório.

No que se refere à executoriedade da decisão, como afirmado acima, as decisões prolatadas nas controvérsias eram obrigatórias em todos os períodos analisados. No âmbito do GATT-1947, as decisões não determinavam o modo de sua observância, mas declaravam que os demandados vencidos deveriam tornar suas medidas compatíveis com suas obrigações. De acordo com o artigo 19 do Entendimento sobre Solução de Controvérsias, nos casos em que o painel ou o Órgão de Apelação concluem que a medida questionada é incompatível com o acordo abrangido, faculta-se a recomendação de modo de cumprimento da decisão.

Com relação aos remédios disponibilizados às partes a cujas demandas se deram provimento, o artigo XXIII:2 do GATT-1947 estatuía:

"Se as Partes Contratantes acharem que as circunstâncias são suficientemente graves para justificar tal medida, poderão autorizar a uma ou a várias Partes Contratantes a suspensão, relativamente a tal ou a tais Partes Contratantes, da aplicação de qualquer obrigação ou concessão resultante do presente Acordo". 
No âmbito do GATT-1947, no entanto, somente em um caso foi aprovada a suspensão das concessões de uma parte contratante em relação à parte que não havia observado a decisão: o EUA - Quotas para Laticínios apresentado pela Holanda. Ao longo de todo o período de vigência do GATT-1947, não houve nenhuma alteração ou suplementação desta regra.

Por outro lado, a fase de implementação das decisões foi detalhadamente regulamentada pelo Entendimento sobre Solução de Controvérsias. Este instrumento estabelece um procedimento para determinação da implementação (artigo 21.5), a faculdade de compensar (artigo 22.2) e, por fim, um procedimento para suspensão de concessões após arbitragem que determine o montante específico (artigo 22.2) ${ }^{120}$.

A suspensão de concessões (ou retaliação) é considerada o último remédio à disposição do demandante nos casos em que o demandado não observa a decisão ${ }^{121}$. $\mathrm{O}$. LONG (1987:66) observa que:

\begin{abstract}
"The word 'retaliation' is not to be found $n$ the text of the General Agreement itself, but it is frequently heard in GATT meetings. Nevertheless, it should not be taken to mean more than the reestablishment of the balance of concessions and advantage between member countries. Similarly, action by the Contracting Parties authorizing retaliatory measures does not take the form of a legal sanction. What is sought is a restoration of the balance upset by one of the member countries".
\end{abstract}

$\mathrm{Na}$ prática, a retaliação não é vista com bons olhos, desde o GATT-1947, conforme observa GATT (MTN/SG/W/8):

"Under GATT, the only means of enforce the Contracting Parties's decisions is to authorize the retaliatory suspension of trade concessions and other obligations. Retaliation has generally been regarded as an unsatisfactory enforcement technique because it

\footnotetext{
${ }^{120}$ Observa-se, contudo, que o Entendimento sobre Solução de Controvérsias não estabelece uma seqüência lógica a ser seguida entre o painel do artigo 21.5 e a arbitragem do artigo 22.2. Por esta razão, é possível recorrer à arbitragem do artigo 22.2 sem passar pela determinação do não cumprimento da decisão do OSC. Este problema ficou conhecido como "sequencing" e atrai grande parte da atenção dos membros da OMC no processo de reforma do Entendimento sobre Solução de Controvérsias na Rodada Doha de negociações comerciais multilaterais. A respeito deste tema, v., por exemplo, A. AMARAL JR. et al (2006:84ss), S. Charnovitz (2001) e M. L. Busch e E. REINHARDT (2003).

121 A respeito do debate sobre a retaliação e os países em desenvolvimento, v. A. AMARAL JR. et al (2006:84ss).
} 
leads to lower levels of trade liberalization, it may snowball, and the cp applying the sanction suffers itself to the extent that it loses the benefits of the international division of labour".

Embora S. Charnovitz (2001) defenda que a retaliação passou a ser interpretada de modo diverso na OMC, o Entendimento sobre Solução de Controvérsias declara, expressamente, que tanto a compensação quanto a retaliação são medidas temporárias que não substituem a retirada da medida incompatível com as regras dos acordos abrangidos (artigo 22.1).

Verifica-se, portanto, que, tanto no GATT-1947 quanto na OMC, as decisões prolatadas pelos órgãos competentes para solução de controvérsias não têm efeitos diretos no ordenamento jurídico dos demandados ${ }^{122}$.

\subsection{Conclusão}

A partir da aplicação do modelo teórico de juridicização de K. W. ABвOTT et al (2000) no sistema de solução de controvérsias do sistema multilateral de comércio, é possível verificar que houve avanço no processo de juridicização ao longo de sua vigência. Este processo foi ocasionado pela institucionalização dos procedimentos de solução de controvérsias a partir do fim da Rodada Tóquio.

Embora tenha sido verificado certo avanço no processo de juridicização, contudo, como órgãos políticos dos quais participam as partes da controvérsia prevaleceram como os competentes para a solução das controvérsias surgidas no âmbito do sistema, é baixo o grau de juridicidade atribuído ao sistema. Neste sentido, no âmbito do GATT-1947, as Partes Contratantes (ou Conselho, entre sessões das Partes Contratantes) eram esse órgão político, enquanto, na OMC, é o OSC.

Não obstante tenha continuado este baixo grau de juridicidade no órgão competente para solução de controvérsias, observa-se que houve alteração significativa das regras relativas aos órgãos que o auxiliam no processo de tomada de decisão entre os dois períodos. Assim, enquanto, nas primeiras fases do GATT-1947, não havia nem mesmo regulamentação dos procedimentos a serem seguidos, o Entendimento de Solução de

\footnotetext{
${ }^{122}$ A discussão relativa a efeitos diretos das decisões encontra-se resumida em S. CHARNOVITZ (2001).
} 
Controvérsias criou o Órgão de Apelação e atribuiu-lhe competência para se manifestar sobre os aspectos legais do relatório do painel exclusivamente.

Os relatórios emitidos pelos órgãos auxiliares (grupos de trabalho e painéis) eram considerados opiniões consultivas com base nas quais as Partes Contratantes fundamentavam sua decisão (GATT:MTN/SG/W/8). Da mesma forma, no âmbito da OMC, tais relatórios não têm força por si só, visto que, para produção de algum efeito, precisam passar pelo crivo do OSC - o órgão competente. 


\section{UTILIZAÇÃO DE ELEMENTOS NORMATIVOS NAS DISPUTAS APRESENTADAS PERANTE O SISTEMA MULTILATERAL DE COMÉRCIO}

\subsection{Notas introdutórias}

As conclusões do capítulo 2 demonstram que não houve alteração do nível de juridicidade do mecanismo de solução de controvérsias da passagem do Entendimento de 1979 (no âmbito do GATT-1947) para o Entendimento sobre Solução de Controvérsias (na $\mathrm{OMC}$ ), pois, em ambos os períodos havia acordos que regulamentavam os procedimentos a serem seguidos e a competência para solução de controvérsias era atribuída a um órgão político.

Como explanado no capítulo 1, diferentes mecanismos de solução de controvérsias detêm graus diversos de juridicidade. Pressupõe-se, portanto, que este grau de juridicidade é refletido nas manifestações de tais mecanismos nos procedimentos instaurados. Em conseqüência, tendo em vista a conclusão do capítulo 2, há de supor que o nível de juridicidade das decisões emitidas no âmbito da OMC seja similar àquele das do GATT-1947.

O objetivo do presente capítulo, neste sentido, consiste em verificar se esta assertiva é comprovada na prática. Para tanto, procede-se à identificação dos tipos de elementos utilizados pelas partes das disputas e dos decisores em cada caso.

No item 3.2, são apresentadas as disputas que serão objeto de análise neste capítulo. A análise destas decisões é marcada por algumas dificuldades, que são apresentadas no item 3.3.

Em seguida, será realizada a análise dos excertos selecionados das decisões apresentadas (item 3.4). Os elementos relevantes para esta pesquisa serão classificados, no 
item 3.5, de modo a facilitar a identificação das conclusões que podem ser extraídas deste capítulo (item 3.6).

\subsection{Contenciosos selecionados}

Como explanado na introdução desta pesquisa, foram selecionados para análise os relatórios das disputas em que se suscitou o artigo XX(g) do GATT para justificação da medida questionada.

O primeiro caso que preenche as características citadas foi apresentado ainda sob a vigência do GATT-1947 e foi denominado EUA - Atum do Canadá (1980-1982), ${ }^{123}$. A demanda foi apresentada pelo Canadá, para questionar a proibição estadunidense das importações de atum e produtos que o contivesse provenientes do Canadá de acordo com a Seção 205 do Fishery Conservation and Management Act de 1976. O demandante alegava que tal proibição violava os artigos I, XI e XIII do GATT-1947, mas os EUA defendiam que a medida era justificada pelo artigo $\mathrm{XX}(\mathrm{g})$ do mesmo instrumento.

Os EUA apresentaram a segunda demanda analisada, no âmbito do GATT1947, que foi o contencioso Canadá - Arenque e Salmão (1986-1988), no qual se questionava a obrigatoriedade de processamento, em território nacional, do arenque e do salmão canadenses antes de sua exportação. De acordo com o demandante, tal medida violava o artigo XI do GATT-1947; o Canadá, por sua vez, justifica-a com base nos artigos $\mathrm{XX}(\mathrm{g})$ e XI:2(b) do mesmo instrumento.

A terceira disputa selecionada (e última no âmbito do GATT-1947) foi a EUA -Automóveis (1992-1994), cujo demandante eram as CE. Estas alegavam que três impostos cobrados pelos EUA a partir do consumo de combustível dos automóveis (Gas Guzzler Tax, Luxury Tax e Corporate Average Fuel Economy Tax) eram incompatíveis com o artigo III do GATT-1947 - medidas justificadas, pelo demandado, com base nos artigos $\mathrm{XX}(\mathrm{g})$ e $\mathrm{XX}(\mathrm{d})$ do referido acordo. Das três medidas questionadas pelas $\mathrm{CE}$, o artigo XX(g) não foi utilizado para justificação da Luxury Tax, e o painel concluiu que o

\footnotetext{
${ }^{123}$ No apêndice C, encontram-se os seguintes dados a respeito das disputas analisadas neste capítulo: título, demandante, demandado, terceiras partes, painelistas/membros do Órgão de Apelação, documentos relativos à disputa e cronologia.
} 
Gas Guzzler Tax não violava os artigos primários citados pelo demandante. Deste modo, o painel manifestou-se sobre o artigo $\mathrm{XX}(\mathrm{g})$ do GATT-1947 apenas com relação ao Corporate Avarage Fuel Tax.

A disputa seguinte foi apresentada no âmbito da OMC. Venezuela e pelo Brasil questionaram os EUA no caso EUA - Gasolina (1995-1996). Os demandantes questionavam a decisão Regulation of Fules and Fuel Additives - Standards for Reformulated and Conventional Gasoline adotada pela Environmental Protection Agency dos EUA, em 15 de dezembro de 1993, para regulamentar o Clean Air Act de 1963. Com o objetivo de prevenir e controlar a poluição do ar nos EUA, a regulamentação questionada estabelecia especificações para a composição e o desempenho dos combustíveis vendidos no território dos EUA.

De acordo com a Venezuela e o Brasil, a medida era incompatível com os Artigos I e III do GATT-1994 e com o Artigo 2 do Acordo sobre Barreiras Técnicas ao Comércio. Os EUA discordavam e, além disso, alegavam que era justificada pelos Artigos $\mathrm{XX}(\mathrm{b})$, (d) e (g) do GATT-1994. A disputa passou por um painel e pelo Órgão de Apelação $^{124}$.

O último caso analisado foi o EUA - Camarões (1996-1998), apresentado por Malásia, Tailândia, Paquistão e Índia em face dos EUA, para questionar a proibição das importações de camarão imposta pela Section 609 da US Public Law 101-162 e a Revised Notice of Guidelines for Determinging Comparability of Foreign Programs for the Protection of Turtles in Shrimp Trawl Fishing Operations. Os demandantes alegavam que a medida questionada era incompatível com os artigos I, XI e XIII do GATT. Os EUA alegavam que era justificada pelos Artigos XX(b) e (g) do mesmo instrumento.

\subsection{Dificuldades na análise das decisões das disputas no sistema multilateral de comércio}

A análise integral das decisões que emanam do sistema multilateral de comércio encontra algumas dificuldades, que prejudicam sua completude, em razão da

\footnotetext{
${ }^{124}$ Este foi o primeiro caso sobre o qual o Órgão de Apelação se manifestou.
} 
impossibilidade de acesso às fontes primárias necessárias para identificação dos fatores analisados.

Neste sentido, tanto no GATT-1947 quanto na OMC, verifica-se a regra do sigilo quanto aos documentos circulados nos procedimentos. Assim, não são divulgadas as petições das partes das controvérsias, as demais comunicações destas com o painel ou a divisão do Órgão de Apelação e o relatório interino circulado pelos painelistas, dentre outros documentos.

Como observado na introdução, as partes podem divulgar suas petições e manifestações nas audiências orais voluntariamente. Não há, contudo, previsibilidade quanto à sua ocorrência. Não se permite, contudo, que uma parte divulgue os documentos apresentados por qualquer outra parte da controvérsia.

Desta forma, os argumentos apresentados nestes documentos são extraídos dos relatórios analisados, os quais os sintetizam e constituem, portanto, fontes secundárias. A experiência demonstra que os relatórios dos painéis e do Órgão de Apelação não copiam as justificações dadas pelos membros em sua totalidade.

No caso específico do GATT-1947, não havia um sistema amplo de sistematização e catalogação dos documentos circulados nas disputas específico ao sistema de solução de controvérsias. Até julho de 1989, estes recebiam o mesmo símbolo que todos os documentos analisados pelas Partes Contratantes. Apenas a partir de então, eles passam a receber, também, o símbolo DS seguido do número da disputa (cronologicamente), uma barra e o número do documento. Este sistema vige na $\mathrm{OMC}$, desde o primeiro pedido de consultas apresentado.

Diante deste cenário, a análise apresentada no próximo item pode vir a ser complementada a partir do acesso aos documentos originais que foram apresentados no decorrer dos procedimentos.

\subsection{Justificação externa de medidas relativas à conservação de recursos naturais exauríveis}

\subsubsection{EUA - Atum do Canadá}


Os argumentos apresentados pelas partes da disputa em relação à caracterização da medida questionada como "relativa à conservação de recursos naturais exauríveis" podem ser organizados em dois grupos: aqueles cujo objetivo consiste em provar que o recurso natural objeto da proteção é exaurível; e os dirigidos à determinação do nexo entre a medida questionada e a conservação do referido recurso.

Observa-se que este caso foi o primeiro em que foi apresentada uma defesa com base no artigo XX do GATT em um procedimento de solução de controvérsias perante o sistema multilateral de comércio. Tanto as partes da disputa quanto o painel começaram sua análise pelos termos do caput, para passarem, em seguida, aos da alínea $g$.

Com relação à caracterização do recurso natural protegido, qual seja, os cardumes de determinadas espécies de atum, como exaurível, os EUA afirmavam que, como os cardumes de atum poderiam ser superexplorados, constatava-se a possibilidade de sua exaustão. De fato, de acordo com uma lista preparada pelo US National Marine Fisheries Service, verificava-se que o atum albacore, o yellowfin e o bluefin eram sujeitos à exploração intensiva nas regiões dos Oceanos Pacífico e Atlântico onde se encontravam seus respectivos cardumes. Isso representava um perigo iminente para a manutenção de suas espécies.

O Canadá, por sua vez, concordava com os EUA que o atum era um recurso natural exaurível. Deste modo, o painel aceitou como incontroversa a caracterização das espécies de atum como recurso natural exaurível e, portanto, não desenvolveu sua própria posição $^{125}$.

No que se refere aos argumentos sobre o nexo entre a medida questionada e a conservação do recurso natural protegido, no entanto, não houve acordo entre as partes. Nesse sentido, os EUA indicavam a inexistência de alternativas à medida que haviam adotado. De fato, a parte contratante julgava que a restrição da pesca em seu território seria infrutífera, se outros territórios continuassem a permitirem a pesca predatória das espécies de atum protegidas em seu território. Além disso, medidas unilaterais teriam efeitos contrários à conservação, porque desencorajariam a cooperação internacional contra a pesca predatória em áreas não sujeitas a restrições.

\footnotetext{
125 De acordo com GATT (L/5198:\$4.9) - o relatório do painel: "The Panel furthermore noted that both parties considered tuna stocks, including albacore tuna, to be an exhaustible natural resource in need of conservation management and that both parties were participating in international conventions aimed, inter allia, at a better conservation of such stocks".
} 
Os EUA também indicavam a coerência de sua política nacional de conservação. De acordo com tal país, não haveria necessidade de que o único objetivo da medida fosse a conservação do recurso natural exaurível - bastava a medida estar relacionada a tal objetivo.

Nesse sentido, o embargo imposto deveria ser analisado no contexto da Seção 205 do Fishery Conservation and Management Act de 1976, a qual o fundamentou e dentre cujos objetivos se encontrava a promoção da cooperação internacional para conservação dos recursos objeto de proteção. Deste modo, o outro objetivo da seção (evitar que certos países declarassem sua soberania sobre 200 milhas náuticas a partir da linha de demarcação de seu mar territorial) era legítimo e não prejudicava a política de conservação do país.

De forma complementar, não haveria a obrigatoriedade de que todos os atores envolvidos nos procedimentos sempre mencionassem o objetivo de conservação em seus atos. O próprio histórico legislativo da medida já demonstraria sua importância. Isto também era verdade no que se refere ao entendimento firmado entre EUA e Canadá após o início da disputa. Assim, este entendimento não precisaria citar, expressamente, o objetivo de conservação, mas apenas ser coerente com a abordagem internacional de conservação dos cardumes de atum.

O Canadá discordava dos EUA em relação à coerência dos objetivos e das características de sua política e de sua conduta. Neste sentido, por exemplo, ressaltava que, no histórico da produção legislativa da medida questionada, prevaleciam as referências à prisão de barcos de pavilhão estadunidense efetuada pelo Canadá como razão para imposição da medida ${ }^{126}$. De fato, este teria sido o único motivo citado quando da publicação da imposição do embargo.

Deste modo, possíveis objetivos de conservação não tinham relevância em face do problema relativo à declaração de mar territorial de 200 milhas náuticas. Isto seria evidenciado pelo fato de os EUA terem levantado o embargo após entendimento entre as duas partes sobre acesso às suas águas para pesca. Observa-se que não havia nenhuma disposição relativa à conservação no referido entendimento; e que, durante as consultas

\footnotetext{
126 Estes barcos haviam sido apreendidos pelo Canadá, por pescarem em suas águas sem autorização específica.
} 
com os EUA, este país não teria levantado a questão da conservação do recurso em nenhum momento.

Por fim, o Canadá alegava que não se podia comprovar que a proibição imposta pelos EUA das importações de atum proveniente do Canadá tinha efeitos sobre a conservação dos recursos supostamente protegidos.

O painel decide que a medida estadunidense questionada não observa os requisitos em análise, porque foi adotada em razão da apreensão dos barcos dos EUA ${ }^{127}$.

\subsubsection{Canadá - Arenque e Salmão}

Neste caso, em que estiveram envolvidos, novamente, EUA e Canadá - agora, em posições invertidas -, a abordagem de exame do artigo XX do GATT-1947 foi diferente. Neste sentido, embora as partes tenham iniciado sua análise a partir dos termos do caput, o painel o fez a partir da alínea questionada. Observa-se que, embora este seja o método que consolidado ao longo dos diversos procedimentos em que surgiram defesas com base no artigo XX do GATT, não foi apresentada nenhuma fundamentação para a escolha neste momento.

Além dos argumentos relativos à caracterização do recurso natural como exaurível e do nexo entre a medida questionada e sua conservação, surgem argumentos dirigidos à definição do escopo do termo "conservação" nesta disputa.

No que se refere à caracterização do arenque e do salmão como recursos naturais exauríveis, observa-se que não houve discordância entre as partes da controvérsia. Deste modo, o painel aceitou como incontroversa a quesão e afirmou concordar com as partes $^{128}$.

\footnotetext{
${ }^{127}$ A decisão do painel sobre este ponto foi bastante sucinta, cf. GATT (L/5198:\$4.13): "The panel also noted that the United States prohibition of imports of all tuna and tuna products from Canada had been imposed in response to Canadian arrest of US vessels fishing albacore tuna. The Panel could not find that this particular action would in itself constitute a measure of a type listed in Article XX".

${ }^{128}$ Cf. GATT (L/6268:§4.4), a decisão foi a seguinte: "The panel agreed with the parties that salmon and herring stocks are "exhaustible natural resources" and the harvest limitations "restriction on domestic production" within the meaning of Article XX(g)".
} 
Com relação ao conceito de conservação, enquanto o Canadá defendia uma conceito mais amplo, os EUA alegavam que, ao contrário, todas as exceções do artigo XX deveriam ser interpretadas restritivamente.

Neste sentido, o Canadá alegava que o termo conservação deveria objetivar não apenas a manutenção de determinados níveis do recurso protegido, mas também de outros elementos científicos e econômicos derivados de sua utilização. No caso de recursos pesqueiros, "the concept of conservation had evolved to include socio-economic as well as biological dimensions which had been embodied into international as well as bilateral agreements and treaties guiding fisheries management” (GATT:L/6268,§3.37). Estes poderiam incluir os acordos celebrados pelos EUA e o Canadá, no âmbito de suas relações bilaterais, como a International Convention for the High Seas Fisheries of the North Pacific de 1952 - emendada em 1979 e 1986 - e o tratado de 1985 entre os dois governos relativo ao salmão presente no Oceano Pacífico, além da própria UNCLOS de 1982, a qual detém diversos dispositivos relativos a princípios sobre conservação de recursos pesqueiros.

Os EUA discordavam da posição do Canadá com base no preâmbulo do artigo $\mathrm{XX}$ : as exceções deveriam ser interpretadas restritivamente para evitar restrições veladas ao comércio internacional. Ademais, outros acordos internacionais não modificariam as obrigações assumidas perante o Acordo Geral - e, ainda que isso fosse possível, em sua opinião, os acordos citados não corroboravam a posição canadense.

A definição do escopo de uma política de conservação era completada pela análise do nexo entre a medida questionada e a conservação do recurso natural. De acordo com o Canadá (GATT:L/6268,§3.26), a redação do artigo XX(g) deixava claro que, para que pudesse desfrutar da proteção oferecida pelo artigo, bastava a medida questionada ser relativa à conservação. Neste sentido, a medida não precisaria ser necessária ou essencial para a conservação. Estes eram termos utilizados em outras alíneas do mesmo artigo, razão pela qual deveriam ser interpretados de modo diverso.

Segundo o Canadá, a medida visava à coleta de dados estatísticos confiáveis sobre os recursos de arenque e salmão em seu país. O Acordo Geral não obrigava uma parte contratante a ter as mesmas medidas adotadas por outros países para a consecução do mesmo fim. Os dados coletados eram utilizados tanto para determinar se as restrições impostas à pesca haviam sido observadas quanto para aplicar multas para pescadores que haviam extrapolados seus limites. 
Além disso, a medida possibilitava que o governo canadense direcionasse recursos públicos a programas de aprimoramento do salmão em âmbito nacional - o que garantia que a expectativa de benefícios econômicos fosse distribuída por diversos setores da sociedade. De fato, a seletividade dos controles canadenses seria uma indicação clara de que a regulamentação objetivava problemas de conservação e manutenção específicos.

Ainda com relação ao nexo entre a medida questionada e a conservação do arenque e do salmão, o Canadá alega a coerência da política canadense. Neste sentido, além da imposição de processamento em âmbito nacional antes da exportação, também faziam parte da política canadense de conservação: proteção a seu habitat natural; acordos internacionais; manutenção de capacidade de pesca e processamento suficiente para otimizar a utilização das espécies; manutenção de sistemas de pesquisa e informação; e controle sobre a produção interna.

Por fim, o Canadá refere-se à experiência de outros países, dentre os quais os próprios EUA, que manteriam proibições às exportações de determinados peixes. Para os EUA, no entanto, a experiência de outros países (e do próprio Canadá, com relação a outras espécies) demonstra a existência de outros métodos válidos e compatíveis com o GATT-1947, para a consecução do mesmo objetivo, qual seja, a coleta de dados precisos sobre os recursos pesqueiros objeto de extração e exportação. Neste sentido, determinados órgãos de seu governo forneciam dados relativos às importações provenientes do Canadá às autoridades deste país. De acordo com os EUA, nenhum outro país aplicava restrições semelhantes às exportações das mesmas espécies de peixes.

Os EUA defendiam que uma medida que condiciona as exportações de determinado produto a processamento em âmbito nacional não pode ser relativa à conservação do referido produto. De fato, a partir da análise do histórico da elaboração da medida, verifica-se que o Canadá reiteradamente referia-se à necessidade de garantir suprimento às suas empresas de processamento.

A incoerência da política canadense de conservação poderia ser comprovada ainda pelo fato de outras espécies de peixes igualmente importantes para o Canadá serem administradas pelo país de forma diversa, ainda que enfrentassem os mesmos problemas que as espécies objeto da medida questionada. Embora o governo canadense alegasse que a medida visava à criação de programas de aprimoramento, os EUA observaram que não havia nenhum programa deste tipo para as espécies de arenque. 
Em sua decisão, o painel observa que o relatório anterior (EUA - Atum) não havia chegado a definir o conteúdo da expressão "relativa a". Por isso, concluiu que caberia a si a tarefa de definir seu conteúdo à luz do contexto em que o artigo $\mathrm{XX}(\mathrm{g})$ aparece no GATT-1947 e de seu objetivo. Neste sentido, o painel observou que o termo "relativa a" não pode ser interpretado como "necessária" ou "essencial", porque estes termos aparecem em outras alíneas. Logo, compreenderia um leque mais amplo de $\operatorname{medidas}^{129}$.

Não obstante, o caput do artigo XX deixa claro que seu objetivo consiste em não restringir a liberdade de implementação de outras políticas públicas por suas partes. Isto evidenciava que o referido dispositivo não poderia ser interpretado de modo amplo ${ }^{130}$. O painel define, assim, que a expressão "relativa a" deveria ser interpretado como "primarily aimed at".

A partir desta afirmação, o painel decide que a medida canadense questionada não é relative à conservaçaõ do arenque e do salmão com base na incoerência da conduta do Canadá ${ }^{131}$.

Interessante notar que, neste caso, o painel refutou expressamente a utilização de normas que não fossem parte do sistema multilateral de comércio como fundamentação em sua decisão ${ }^{132}$.

129 Cf. GATT (L/6268:\$4.6), o excerto respectivo é o seguinte: "The panel noted that some of the subparagraphs of Article XX state that the measure must be "necessary" or "essential" to the achievement of the policy purpose set out in the provision (cf. subparagraphs $(a),(b),(d)$ and $(j))$ while subparagraph ( $g$ ) refers only to measures "relating to" the conservation of exhaustible natural resources. This suggests that Article XX $(g)$ does not only cover measures that are necessary or essential for the conservation of exhaustible natural resources but a wider range of measures".

${ }^{130}$ Cf. GATT (L/6268:\$4.6), o excerto respectivo é o seguinte: "However, as the preamble of Article XX indicates, the purpose of including Article XX(g) in the General Agreement was not to widen the scope for measures serving trade policy purposes but merely to ensure that the commitments under the General Agreement do not hinder the pursuit of policies aimed at the conservation of exhaustible natural resources. The Panel concluded for these reasons that, while a trade measure did not have to be necessary or essential to the conservation of an exhaustible natural resource, it had to be primarily aimed at the conservation of an exhaustible natural resource to be considered as 'relating to' conservation within the meaning of Article $X X(g)$ ".

${ }^{131}$ Cf. GATT (L/6268:\$4.7), o excerto respectivo é o seguinte: "Canada collects statistical data on many different species of fish, including certain salmon species, without imposing export prohibitions on them. Canada maintains statistics on all fish exports. If certain unprocessed salmon and unprocessed herring were exported, statistics on these exports would therefore be collected. The Salmonid Enhancement Program covers salmon species for which export prohibitions apply and other species not subject to export prohibitions. The export prohibitions do not limit access to salmon and herring supplies in general but only to certain salmon and herring supplies in unprocessed form. Canada limits purchase of these unprocessed fish only by foreign processors and consumers and not by domestic processors and consumers". 


\subsubsection{EUA - Automóveis}

O terceiro e último caso em que se discutiu a aplicação do artigo $\mathrm{XX}(\mathrm{g})$ do GATT-1947 antes da criação da OMC foi o EUA - Automóveis, em que tanto as partes quanto o painel iniciaram a análise do artigo a partir dos termos da alínea $g$. Os argumentos analisados foram organizados em dois grupos, quais sejam, os relativos à caracterização do recurso natural como exaurível e os referentes ao nexo entre a medida questionada e a conservação do recurso natural protegido.

Com relação à caracterização como recurso natural exaurível, não houve desacordo entre as partes da controvérsia quanto a validade de políticas que objetivassem a conservação de reservas naturais de combustíveis fósseis, que são limitadas em todo o mundo, e da qualidade do ar. De fato, as CE nem mesmo apresentaram argumentos específicos que a questionassem.

O painel decidiu que uma política voltada para a conservação da gasolina estava no âmbito daquelas previstas pelo artigo XX do GATT, porque a gasolina era proveniente do petróleo, um recurso natural exaurível ${ }^{133}$.

No que se refere ao nexo entre a medida questionada e a conservação do recurso natural exaurível, os EUA observaram que as regras relativas à economia de combustível previstas em sua política haviam sido reconhecidas internacionalmente como um sucesso para a redução do consumo de petróleo e das emissões de dióxido de carbono de outros gases que contribuem para o aquecimento global e a perda da camada de ozônio.

Com base na decisão do caso Canadá - Arenque e Salmão, os EUA reconhecem que a medida questionada precisa ser "primarily aimed at" a conservação do recurso natural exaurível protegido (GATT:DS31/R,§3.319). De acordo com sua posição, este requisito era preenchido a partir da análise em conjunto dos programas Corporate

\footnotetext{
${ }^{132}$ Cf. GATT (DS31/R:§5.3), o excerto respectivo é o seguinte: "Canada referred in its submission to international agreements on fisheries and the Convention on the Law of the Sea. The Panel considered that its mandate was limited to the examination of Canada's measures in the light of the relevant provisions of the General Agreement. This report therefore has no bearing on questions of fisheries jurisdiction".

${ }^{133}$ Cf. GATT (DS31/R:§5.57), o excerto respectivo é o seguinte: "The panel, noting that gasoline was produced from petroleum, an exhaustible natural resource, found that a policy to conserve gasoline was within the range of policies mentioned in Article XX(g)".
} 
Average Fuel Economy Tax e Gas Guzzler Tax, os quais previam um conjunto de meios apropriados e razoáveis para a conservação de combustível no setor de transportes.

Este objetivo seria alcançado por meio do aprimoramento da eficiência do consumo de combustíveis das frotas de veículos. Sem isto, o único mecanismo disponível para redução do consumo de combustível seria a redução do número de viagens ou a taxação do próprio combustível - o que seria contraprodutivo (dados o tamanho e as características do país), não produziria inovação tecnológica de longo prazo e sobrecarregaria os cidadãos de menor renda. De fato, tais medidas teriam efeitos prejudiciais sobre a economia dos EUA.

O demandado defendeu que não havia nenhuma disposição no GATT-1947 que obrigasse uma parte contratante a adotar uma medida draconiana simplesmente porque seria mais conveniente para certos produtos situados no território de outras partes contratantes.

O consumo de combustível representava grande parcela do total de consumo de energia nos EUA, o que resultava em volume elevado de emissões de carbono. Além disso, um estudo preparado pela National Academy of Sciences listou como benefícios decorrentes do menor consumo de combustível: diminuição de despesas, conservação de recursos naturais, aumento da segurança nacional, aumento da qualidade ambiental, aumento da difusão de tecnologia e aprimoramento da eficiência econômica.

Por fim, os EUA notam que a preocupação com a mudança climática global era documentada por extensa literatura científica e amplamente aceita na comunidade internacional $^{134}$. Esta preocupação teria levado os EUA e mais de 150 países a elaborar um plano de ação conjunta para proteção da atmosfera da Terra sob a Convenção-Quadro das Nações Unidas sobre a Mudança Climática (UNFCCC, sigla em inglês) ${ }^{135}$.

As CE, por sua vez, também com base na decisão do caso Canadá - Arenque e Salmão, afirmavam que a medida questionada não poderia ser justificada pelo artigo $\mathrm{XX}(\mathrm{g})$ do GATT-1947, porque resultava em ônus discriminatório sobre as exportações da região para os EUA.

\footnotetext{
${ }^{134}$ Cf. GATT (DS31/R:§3.323), o excerto respectivo é o seguinte: "Concern about global climate change was documented by extensive scientific literature and was widely accepted in the international community".

${ }^{135}$ Cf. GATT (DS31/R:§3.323), o excerto respectivo é o seguinte: “This concern had led the United States and over 150 other countries to pledge joint action to protect the earth's atmosphere under the United Nations Framework Convention on Climate Change".
} 
De forma sucinta, as CE afirmam que, como os importadores e outros produtores costumavam ser mais especializados que os produtores locais dos EUA, as penalidades eram aplicadas de modo diverso - o que, para as CE, seria similar ao efeito analisado no caso Canadá - Arenque e Salmão ${ }^{136}$. Assim, a imposição do método de cálculo não alcança e, em alguns casos, mesmo prejudicaria o objetivo de conservação, porque permitia que os produtores maiores vendessem-se mais carros maiores, que consomem mais combustível ${ }^{137}$.

Por fim, as CE afirmaram que havia meios não discriminatórios de limitar a demanda de combustíveis de carbono, como um tributo calculado para cada carro individualmente de acordo com o nível de consumo de combustível.

Tal como fizeram as partes da disputa, o painel recorre à decisão do caso Canadá - Arenque e Salmão para definir que uma medida relativa à conservação de um recurso natural exaurível é aquela primarily aimed at a conservação. Depois desta constatação, o painel declara que os EUA não haviam apresentado prova de que a contabilização de frotas de veículos estrangeiros em separado tinha objetivos ambientais e de como os alcançava ${ }^{138}$.

De fato, para o painel as evidências que se lhe haviam sido apresentadas indicavam que a contabilização em separado teria efeitos contrários à proteção do meio ambiente, ao inibir a importação de carros pequenos ${ }^{139}$. Observe-se que, neste caso, o painel adotou a posição de que "a measure that did not further the objectives of conservation of an exhaustible resource could not be deemed to be primarily aimed at such

\footnotetext{
${ }^{136}$ Cf. GATT (DS31/R:§3.317), o excerto respectivo é o seguinte: "Because importers of autos and many other products tended to be much more specialized than domestic manufacturers of like products, it led to different CAFE penalties on like automobiles, and had an effect similar to Canada-Herring and Salmon".

${ }^{137}$ Cf. GATT (DS31/R:\$3.317), o excerto respectivo é o seguinte: "The use of averaging did not advance, and in some respects undermined, the goal of energy conservation because it permitted full-line manufacturers to sell large numbers of cars with high fuel consumption, as long as they were counterbalanced by production of smaller cars".

${ }^{138}$ Cf. GATT (DS31/R:\$5.60), o excerto respectivo é o seguinte: "The panel noted that the United States had provided the Panel with extensive explanations of the environmental objectives of the Motor Vehicle Information and Cost Savings Act and the CAFEstandard, but hat it had provided no evidence that the exclusion of averaging large imported cars with small cars produced in the United States and under the same ownership or control of production furthered these objectives".

${ }^{139}$ Cf. GATT (DS31/R:§5.60), o excerto respectivo é o seguinte: "In fact, the evidence submitted to the Panel suggested that separate foreign fleet accounting primarily served to inhibit imports of small cars. This did not contribute directly to fuel conservation in the United States. Indeed, it was likely to make it more costly, and therefore more difficult, for domestic manufacturers to meet the CAFE standard and the overall goal of conserving fuel'.
} 
conservation and therefore found to be inconsistent with Article III:4 was not justified by Article XX(g)" (Cf. GATT:DS31/R,§5.60).

Assim, como o ônus da prova era imputado aos EUA, o painel decidiu que a medida questionada não poderia ser justificada pelo artigo XX $(\mathrm{g})$ do GATT.

\subsubsection{EUA - Gasolina}

A disputa denominada EUA - Gasolina foi a primeira, no âmbito da OMC, em que se discutiu a aplicação do artigo XX(g) do GATT-1994. Tal como ocorrera no caso anterior, tanto as partes quanto o painel e o Órgão de Apelação analisaram os termos da alínea antes de passarem à análise do caput.

De acordo com os EUA, o recurso natural cuja conservação se buscava era o “ar limpo" (OMC:WT/DS2/R:§3.59), o qual se constituía em recurso exaurível, visto que seu suprimento poderia acabar caso continuassem as emissões de poluentes. Em áreas muito poluídas, o ar poderia ser tornar contaminado de forma permanente e permanecer assim por longos períodos. $\mathrm{O}$ ar poluído ainda podia se movimentar por longas distâncias e contaminar áreas antes não poluídas. Ademais, o fim da degradação do ar possibilitaria que outros recursos naturais fossem beneficiados, como lagos, córregos, parques, plantações e florestas, que recebem os efeitos negativos da poluição.

Diante deste cenário, os EUA reiteravam sua posição de que o ar constituía, sem dúvida, um recurso natural que poderia ser exaurido, caso se tornasse inadequado para o consumo humano, animal ou vegetal. Em sua opinião, isto era similar à decisão, de painéis anteriores (em especial, Canadá - Arenque e Salmão), de que os peixes poderiam ser considerados recursos naturais exauríveis, pois suas populações poderiam ser extintas (OMC:WT/DS2/R:§3.62).

Apesar de afirmar que se preocupava com o impacto do ar poluído sobre a saúde dos seres humanos, a Venezuela não concordava que o ar puro pudesse ser considerado um recurso natural exaurível, pois a pureza do ar era uma qualidade do recurso e não um recurso em si (OMC:WT/DS2/R:§3.60). Segundo o país, esta posição apoio em decisões de painéis anteriores, os quais afirmaram que o artigo XX deve ser interpretado restritivamente. Tais decisões seriam as dos seguintes casos: EUA - Atum; 
Canada - Administration of the Foreign Investment Review Act; e United States - Section 337 of the Tariff Act of 1930.

O painel, entretanto, reconheceu que o ar puro era um recurso (pois tinha valor) e era natural, além de poder acabar. $\mathrm{O}$ ar puro poderia ser considerado, portanto, um recurso natural exaurível. $O$ fato de se vincular uma qualidade do recurso não era determinante. Como também não o era, o fato de ser renovável - neste sentido, o painel do caso Canadá - Arenque e Salmão havia aceito espécies de peixes como recurso natural exaurível $^{140}$.

Embora Venezuela e Brasil não tenham apelado da decisão do painel de que ar puro poderia ser considerado um recurso natural exaurível, nas manifestações que apresentaram ao longo do procedimento de apelação, questionaram tal decisão.

Os EUA alegaram que isso não seria possível, porque implicaria em injustiça (unfairness) em relação aos EUA e iria contra as regras de procedimento do Órgão de Apelação $^{141}$. Além disso, criaria dificuldades para as terceiras partes, que deveria ter se decidido sobre participar dos procedimentos com base na notificação de apelação ${ }^{142}$.

O Órgão de Apelação decidiu que, de fato, não poderia considerar as manifestações do Brasil e da Venezuela nem mesmo como apelações condicionadas à modificação da decisão do painel ${ }^{143}$. Isso porque o tema não era imprescindível para

${ }^{140} \mathrm{Cf}$. OMC (WT/DS2/R:§6.37), o excerto do relatório com a decisão do painel sobre esta questão é a seguinte: "In the view of the Panel, clean air was a resource (it had value) and it was natural. It could be depleted. The fact that the depleted resource was defined with respect to its qualities was not, for the Panel, decisive. Likewise, the fact that a resource was renewable could not be an objection. A past panel had accepted that renewable stocks of salmon could constitute an exhaustible natural resource".

${ }^{141}$ Cf. OMC (WT/DS2/AB/R:11), o excerto respectivo do relatório do Órgão de Apelação é o seguinte: "In its Post-Hearing Memorandum, the United States asserted, among other things, that were the Appellate Body to take up the above two matters in the present appeal, unfairness would be generated vis-à-vis the United States and it would encourage a disregard of the Working Procedures".

${ }^{142}$ Cf. OMC (WT/DS2/AB/R:11), o excerto respectivo do relatório do Órgão de Apelação é o seguinte:: "Such disregard by the Appellate Body would, it was further stated, create difficulties for third parties who would have to make up their minds to become third participants or not on the basis of the issues raised on appeal as set out in the Notice of Appeal and the Appellant's submission".

${ }^{143}$ Cf. OMC (WT/DS2/AB/R:12), o excerto respectivo do relatório do Órgão de Apelação é o seguinte:: "We observe, in the first place, that the issues in fact raised by the Appellant, the United States, are not of the kind which cannot be decided without at the same time necessarily resolving the clean air issue or the applicability of the TBT Agreement. In the second place, to deal with those two issues, under the circumstances of this appeal, would have required the Appellate Body casually to disregard its own Working Procedures and to do so in the absence of a compelling reason grounded on, for instance, fundamental fairness or force majeure. Venezuela and Brazil could have appealed the Panel's finding and non-finding on the two matters by taking advantage of Rules 23(1) or 23(4) of the Working Procedures and thereby placing 
análise da apelação dos EUA e não havia "compelling reason grounded on, for instance, fundamental fairness or force majeure" para justificar a não observância das regras de procedimento. A Venezuela e o Brasil tinham tido oportunidade de apelar, mas não o fizeram.

Com relação ao nexo entre a medida questionada e a conservação do recurso natural supostamente protegido, a Venezuela alegou que este requisito não havia sido preenchido no caso concreto. Neste sentido, para o referido país, com base na decisão do caso Canadá - Arenque e Salmão (de que a medida deve ser primarily aimed at a conservação do recurso natural exaurível), a metodologia prevista continha escapes que sabotavam a própria conservação do ar, razão pela qual não se deve ser considerada como relativa à proteção do ar puro (OMC:WT/DS2/R,§3.61).

Em sua decisão, o painel retoma a definição de "relativa a" e a declaração do objetivo do artigo XX presentes no relatório da disputa Canadá - Arenque e Salmão. Com isso, o painel declarou que não via nenhuma relação entre o tratamento desfavorável concedido à gasolina importada que fosse quimicamente idêntica à gasolina nacional dos EUA e o objetivo de preservar o ar puro ${ }^{144}$. O painel ainda destacou que a observância da obrigação de conceder tratamento nacional não impediria a consecução do objetivo declarado pelos EUA, visto que este país continuaria livre para estabelecer o nível de proteção desejada $^{145}$.

O Órgão de Apelação criticou a decisão do painel, por ter analisado a discriminação em vez da medida questionada, como disposto pelo caput do artigo XX. Outro erro do painel, de acordo com o Órgão de Apelação, teria sido considerar como sinônimas as expressões "in direct connection" e "primarily aimed at", sem deixar claro se é esta mesmo sua posição. Por fim, o painel pareceria aplicar o teste de necessidade da alínea $b$ para interpretação da $g$, embora o conectivo desta alínea fosse outro (OMC:WT/DS2/AB/R,15).

the Appellate Body in a position to dispose of those issues directly in one and the same appellate proceeding".

${ }^{144}$ Cf. OMC (WT/DS2/R:§6.40), o excerto respectivo do relatório do painel é o seguinte: "The Panel saw no direct connection between less favourable treatment of imported gasoline that was chemically identical to domestic gasoline, and the United States objective of improving air quality in the United States".

${ }^{145} \mathrm{Cf}$. OMC (WT/DS2/R:§6.40), o excerto respectivo do relatório do painel é o seguinte: "Indeed, in the view of the Panel, being consistent with the obligation to provide no less favourable treatment would not prevent the attainment of the desired level of conservation of natural resources under the Gasoline Rule. (...) Indeed, the US remained free to regulate in order to obtain whatever air quality it wished". 
Para o Órgão de Apelação, a principal razão do erro do painel foi não ter seguido uma regra fundamental de interpretação de tratados que havia sido citada, pelo menos, em um ou outro momento por todas as partes da disputa e as terceiras partes: a regra refletida no artigo 31 da Convenção de Viena sobre Direito dos Tratados, a qual já havia atingido o status de direito internacional consuetudinário ${ }^{146}$.

Para comprovar que a regra havia atingido de fato o status de direito consuetudinário, o Órgão de Apelação cita, então, na nota de rodapé número 34, uma decisão da $\mathrm{CIJ}^{147}$, uma decisão da Corte Européia de Direitos Humanos $(\mathrm{CEDH})^{148}$, uma decisão da $\mathrm{CIDH}^{149}$, um doutrinador espanhol ${ }^{150}$, um francês ${ }^{151}$ e outro inglês ${ }^{152}$.

Tal comprovação possibilitava que a regra citada fosse utilizada conforme os termos do artigo 3.2 do Entendimento sobre Solução de Controvérsias. Deste modo, o Órgão de Apelação volta-se às demais alíneas do próprio artigo XX do GATT-1994, com o intuito de estabelecer alguma gradação, em razão dos diversos conectivos nelas utilizados, para designar diferentes níveis de relação. Para o Órgão de Apelação, não seria razoável aplicar o mesmo nível de relação em todas as exceções previstas, se o texto previa, expressamente, palavras diferentes.

\footnotetext{
${ }^{146} \mathrm{Cf}$. OMC (WT/DS2/AB/R:16), o excerto respectivo do relatório do do Órgão de Apelação é o seguinte: " $A$ principal difficulty, in the view of the Appellate Body, with the Panel Report's application of Article XX $(g)$ to the baseline establishment rules is that the Panel there overlooked a fundamental rule of treaty interpretation. This rule has received its most authoritative and succinct expression in the VCLT (the 'Vienna Convention') which provides in relevant part: Article 31 General rule of interpretation 1. A treaty shall be interpreted in good faith in accordance with the ordinary meaning to be given to the terms of the treaty in their context and in the light of its object and purpose. The 'general rule of interpretation' set out above has been relied upon by all of the participants and third participants, although not always in relation to the same issue. That general rule of interpretation has attained the status of a rule of customary or general international law".

147 Referência indicada no relatório do Órgão de Apelação: "Territorial Dispute Case (Libyan Arab Jamahiriya v. Chad), (1994), I.C.J. Reports p. 6".

${ }^{148}$ Referência indicada no relatório do Órgão de Apelação: "Golder v. United Kingdom, ECHR, Series A, (1995) no. 18".

${ }^{149}$ Referência indicada no relatório do Órgão de Apelação: "Restrictions to the Death Penalty Cases, (1986) 70 International Law Reports 449".

${ }^{150}$ Referência indicada no relatório do Órgão de Apelação: “Jiménez de Aréchaga, "International Law in the Past Third of a Century" (1978-I) 159 Recueil des Cours 1, p. 42”.

${ }^{151}$ Referência indicada no relatório do Órgão de Apelação: “D. Carreau, Droit International (3è ed., 1991) p. 140 ".

152 Referência indicada no relatório do Órgão de Apelação: “Oppenheim's International Law (9th ed., Jennings and Watts, eds. 1992) Vol. 1, pp. 1271-1275".
} 
O contexto do artigo $\mathrm{XX}(\mathrm{g})$ ainda incluiria as demais disposições do GATT1994, em especial os artigos I, III e XI; por outro lado, o contexto destes artigos também incluiria o artigo XX. Por esta razão, a expressão "relativa à conservação de recursos naturais exauríveis" não poderia ser interpretada de modo amplo o bastante para colocar em risco os objetivos dos demais artigos, do mesmo modo, que estes não poderiam ser interpretados de modo a tornar ineficazes as exceções do artigo XX (OMC:WT/DS2/AB/R, 18).

Neste contexto, a relação entre os artigos substantivos e as exceções somente poderia ser definida caso a caso, por meio de análise cuidadosa do contexto legal e factual da disputa. Observa-se que o Órgão de Apelação acredita que esta consideração já aparece no relatório Canadá - Arenque e Salmão, o qual é reconhecido por todas as partes da disputa como aplicável no caso concreto. Por esta razão, julga não ser necessário buscar outra interpretação, com a ressalva de que "the phrase "primarily aimed at" is not itself treaty language and was not designed as a simple litmus test for inclusion or exclusion from Article XX(g)" (OMC:WT/DS2/AB/R,18).

Por fim, o Órgão de Apelação decide que a medida deve ser analisada como um todo, pois suas disposições não poderiam ser entendidas fora do contexto em que se encontravam. Neste sentido, as medidas haviam sido elaboradas para permitir a análise o monitoramento do nível de observância das regras ambientais pelos agentes envolvidos no processo produção-venda. Sem um mecanismo deste gênero, não seria possível a avaliação, e, assim, o objetivo da política de conservação não poderia ser alcançado. Deste modo, a medida questionada foi considerada relativa à conservação do ar puro ${ }^{153}$.

\subsubsection{EUA - Camarões}

\footnotetext{
${ }^{153}$ Cf. OMC (WT/DS2/AB/R:19), o excerto respectivo do relatório do do Órgão de Apelação é o seguinte: "Those provisions can scarcely be understood if scrutinized strictly by themselves, totally divorced from other sections of the Gasoline Rule which certainly constitute part of the context of these provisions. The baseline establishment rules whether individual or statutory, were designed to permit scrutiny and monitoring of the level of compliance of refiners, importers and blenders with the "non-degradation" requirements. Without baselines of some kind, such scrutiny would not be possible and the Gasoline Rule's objective of stabilizing and preventing further deterioration of the level of air pollution prevailing in 1990, would be substantially frustrated. The relationship between the baseline establishment rules and the "nondegradation" requirements of the Gasoline Rule is not negated by the inconsistency, found by the Panel, of the baseline establishment rules with the terms of Article III:4".
} 
O último caso analisado, EUA - Camarões, mais uma vez envolveu os EUA, como demandado, mas os demandantes foram quatro países em desenvolvimento: Índia, Malásia, Paquistão e Tailândia. Observa-se que Índia, Paquistão e Tailândia, ao longo de todo o procedimento, apresentaram suas manifestações em conjunto.

Embora as partes tenham iniciado sua argumentação a partir da alínea do artigo XX, o painel partiu dos termos do caput. Esta decisão foi revogada pelo Órgão de Apelação, o qual ressaltou a importância da ordem de análise no resultado da interpretação ${ }^{154}$. Os argumentos apresentados pelas partes e na decisão foram organizados nos dois grupos presentes no caso anterior: os relativos à conceituação de recurso natural exaurível; e aqueles que abordam o nexo entre a medida questionada e o recurso natural alegadamente protegido.

Com relação ao conceito de recurso natural exaurível, a caracterização de tartarugas como tal encontrou obstáculo na posição dos demandantes, que rejeitavam a possibilidade de um ente renovável poder usufruir da proteção oferecida pelo artigo XX(g).

Neste sentido, Índia, Paquistão e Tailândia defendiam que a expressão recursos naturais exauríveis deveria incluir apenas elementos cujas reservas fossem limitadas e não renováveis, como os minerais. Esta interpretação estaria de acordo com a regra do artigo 31 da Convenção de Viena sobre Direito dos Tratados e com o princípio da interpretação efetiva - o qual teria sido consagrado no relatório do Órgão de Apelação no caso EUA Gasolina $-{ }^{155}$, pois se todos os recursos naturais pudessem ser considerados exauríveis, $\mathrm{O}$ termo exaurível tornar-se-ia supérfluo (OMC:WT/DS58/R,§3.237).

Sua posição encontraria suporte também no histórico de negociação do artigo $\mathrm{XX}$, cujos registros incluíam as intervenções de Brasil e Índia em que se citavam recursos minerais como aqueles compreendidos pela alínea discutida ((OMC:WT/DS58/R,§3.2.38).

\footnotetext{
${ }^{154}$ De acordo com o Órgão de Apelação (\$117-119): “117. The above flaws in the Panel's analysis and findings flow almost naturally from the fact that the Panel disregarded the sequence of steps essential for carrying out such an analysis. The Panel defined its approach as first "determin[ing] whether the measure at issue satisfies the conditions contained in the chapeau. "If the Panel found that to be the case, it said that it "shall then examine whether the US measure is covered by the terms of Article XX(b) or (g)."(...) 118. In United States - Gasoline, we enunciated the appropriate method for applying Article XX of the GATT 1994. (...) 119. The sequence of steps indicated above in the analysis of a claim of justification under Article XX reflects, not inadvertence or random choice, but rather the fundamental structure and logic of Article XX. The Panel appears to suggest, albeit indirectly, that following the indicated sequence of steps, or the inverse thereof, does not make any difference. To the Panel, reversing the sequence set out in United States Gasoline "seems equally appropriate."We do not agree".

${ }^{155}$ Este princípio foi indicado nos parágrafos 3.237 e 3.245 de OMC (WT/DS58/R).
} 
Esta posição era compartilhada pela Malásia ${ }^{156}$, que a justificava com base em interpretação sistemática utilizada pelo Órgão de Apelação no caso Japan - Taxes on Alcoholic Beverages (DS11) e nas regras do artigo 31 da Convenção de Viena sobre Direito dos Tratados.

Por fim, Índia, Paquistão e Tailândia consideravam que a decisão da disputa EUA - Gasolina não era aplicável in casu, porque havia se baseado, de forma errônea, em dois painéis do GATT-1947 - Canadá - Arenque e Salmão e United States - Restrictions on Imports of Tuna (CE) -, nos quais as partes não questionaram o recurso objeto da proteção.

Neste contexto, como as tartarugas podiam se reproduzir e são, portanto, recursos renováveis, medidas que objetivassem sua proteção deveriam ser fundamentadas no artigo XX(b) do GATT-1994 e não no artigo XX(g).

Os EUA discordavam da posição dos demandantes e defendia que recursos renováveis também poderiam serem objeto da proteção do artigo XX(g) do GATT. De acordo com o referido país, nada no texto do artigo levava a tal conclusão. Com relação à decisão do caso EUA - Gasolina, os EUA consideravam que seria sim aplicável, para ajudar a esclarecer os termos no caso em discussão.

Por sua vez, a utilização dos trabalhos preparatórios teria sido realizada de forma equivocada pelos demandantes, visto que o artigo 32 da Convenção de Viena sobre Direito dos Tratados prevê o recurso a tais instrumentos apenas nos casos em que, após a aplicação das ferramentas previstas no artigo 31 da Convenção, ainda restarem obscuros os termos a serem interpretados. Não obstante, ainda que fosse considerado válido o recurso aos trabalhos preparatórios, os três países teriam indicado apenas ilustrações não representativas; e os próprios EUA apresentaram exemplo específico em que os delegados se referiam a recursos renováveis (OMC:WT/DS58/R, §3.243).

Por fim, os EUA defendiam que a possibilidade de incluir recursos naturais renováveis não implicava em sobreposição entre as disposições das alíneas $b$ e $g$. Isso porque detêm requisitos e condições diversas, dentre as quais os membros da OMC podem escolher no caso de recursos naturais exauríveis (OMC:WT/DS58/R,§3.244). Neste

\footnotetext{
${ }^{156}$ Esta posição foi expressada nos parágrafos 3.240 e 3.247 de OMC (WT/DS58/R).
} 
sentido, enquanto a alínea $b$ exigia que a medida questionada fosse "necessária", a alínea $g$ apenas requeria que fosse "relativa à" conservação.

Com relação às características das tartarugas marinhas, os EUA ressaltam que as espécies eram "an ancient and distinctive part of the world's biological diversity, and served key functions in the ecosystems they inhabited" (OMC:WT/DS58/R,§3.241). Elas seriam exauríveis, porque correm risco de extinção - este risco é comprovado pela inclusão, desde 1975, de todas as espécies protegidas pela medida estadunidense no Apêndice 1 da Convenção para o Comércio Internacional das Espécies da Flora e Fauna Selvagens em Perigo de Extinção (CITES, sigla em inglês) - convenção de que fazem parte os quatro Estados envolvidos na disputa. Além disso, "other international agreements also recognized the endangered status of sea turtles".

Por ter iniciado sua análise a partir dos termos do caput do Artigo XX e chegado à conclusão de que a medida estadunidense constituía discriminação injustificável, o painel não teve oportunidade de se manifestar sobre os elementos da alínea g. Os EUA apelaram desta decisão, que foi revertida pelo Órgão de Apelação, o qual iniciou a análise do artigo a partir dos termos da alínea.

O Órgão de Apelação, por sua vez, decidiu que a expressão "recursos naturais exauríveis" poderia ser interpretada de modo a incluir recursos bióticos renováveis, visto que "from the perspective embodied in the preamble of the WTO Agreement, we note that the generic term "natural resources" in Article XX(g) is not "static" in its content or reference but is rather "by definition, evolutionary" (OMC:WT/DS58/AB/R,§130). A aplicação do princípio da interpretação evolutiva foi justificada na nota de rodapé número 109, com base em duas decisões da CIJ e em dois trabalhos doutrinários, um espanhol e outro inglês ${ }^{157}$.

Por sua vez, a cláusula preambular do Acordo de Marraqueche que trata do desenvolvimento sustentável também foi esclarecida em nota de rodapé número 107, no

\footnotetext{
157 Texto da referida nota de rodapé tal como presente no relatório do Órgão de Apelação: "See Namibia (Legal Consequences) Advisory Opinion (1971) I.C.J. Rep., p. 31. The International Court of Justice stated that where concepts embodied in a treaty are "by definition, evolutionary", their "interpretation cannot remain unaffected by the subsequent development of law.... Moreover, an international instrument has to be interpreted and applied within the framework of the entire legal system prevailing at the time of the interpretation." See also Aegean Sea Continental Shelf Case, (1978) I.C.J. Rep., p. 3; Jennings and Watts (eds.), Oppenheim's International Law, 9th ed., Vol. I (Longman's, 1992), p. 1282 and E. Jimenez de Arechaga, "International Law in the Past Third of a Century", (1978-I) 159 Recueil des Cours 1, p. 49".
} 
qual se declara que se tem aceito que o conceito de desenvolvimento sustentável compreende a proteção ambiental e o desenvolvimento social e econômico. Esta visão foi justificada com a citação de dois trabalhos doutrinários: um artigo de G. HANDL e o relatório Our Common Future da World Commission on Environment and Development ${ }^{158}$.

Neste sentido, a expressão deveria ser interpretada à luz das preocupações vigentes ao momento da decisão. Deste modo, com base nas lições da biologia moderna e como reconhecido no relatório Our Common Future, da World Commission on Environment and Development (OMC:WT/DS58/AB/R,§128), bem como em convenções e declarações internacionais modernas - como a UNCLOS, a Convenção sobre Diversidade Biológica, a Agenda 21 e a Resolução sobre Assistência a Países em Desenvolvimento adotada com a CITES - que, freqüentemente, citam recursos naturais renováveis como exauríveis, o Órgão de Apelação decidiu que entes bióticos poderiam ser classificados como recursos naturais exauríveis, para fins de aplicação do artigo XX(g) do GATT$1994^{159}$.

Além disso, não havia indicação concreta, nos trabalhos preparatórios, de que a intenção dos negociadores fosse, de fato, restringir o escopo do artigo para incluir apenas entes abióticos ${ }^{160}$. Na mesma linha, dois painéis do GATT-1947 também haviam decidido que peixes seriam recursos naturais exauríveis ${ }^{161}$.

Assim, o Órgão de Apelação declara (OMC:WT/DS58/AB/R,§131): “We hold that, in line with the principle of effectiveness in treaty interpretation, measures to

\footnotetext{
158 Texto original da nota de rodapé incluso no relatório do Órgão de Apelação - (OMC:WT/DS58/AB/R): "This concept has been generally accepted as integrating economic and social development and environmental protection See e.g., G. Handl, "Sustainable Development: General Rules versus Specific Obligations", in Sustainable Development and International Law (ed. W. Lang, 1995), p. 35; World Commission on Environment and Development, Our Common Future (Oxford University Press, 1987), p. $43 ”$.

${ }^{159} \mathrm{Cf}$. OMC (WT/DS58/AB/R:§131), o excerto respectivo da decisão é o seguinte: "Given the recent acknowledgement by the international community of the importance of the concerted bilateral or multilateral action to protect living natural resources, and recalling the explicit recognition by WTO Members of the objective of sustainable development in the preamble of the WTO Agreement, we believe it is too late in the day to suppose that Article XX $(\mathrm{g})$ of the GATT 1994 may be read as referring only to the conservation of exhaustible mineral or other non-living natural resources".

${ }^{160}$ Nota de rodapé que acompanha o texto da nota 159 acima: "Furthermore, the drafting history does not demonstrate an intent on the part of the framers of the GATT 1947 to exclude "living" natural resources from the scope of application of Article XX(g)".

${ }^{161} \mathrm{Cf}$. OMC (WT/DS58/AB/R:§131), o excerto respectivo da decisão é o seguinte: "Moreover, two adopted GATT 1947 panel reports previously found fish to be an 'exhaustible natural resource' within the meaning of Article XX(g)".
} 
conserve exhaustible natural resources, whether living or non-living, may fall within Article XX $(g)$ ". Também o princípio da interpretação efetiva foi justificado no relatório do Órgão de Apelação, na nota de rodapé $116^{162}$, com referência a 3 relatórios anteriores do próprio Órgão de Apelação, 3 trabalhos doutrinários na língua inglesa, 2, em francês e 2, em espanhol.

Após decidir que o termo exaurível inclui os recursos naturais renováveis, o Órgão de Apelação decide que as tartarugas marinhas poderiam ser consideradas recurso natural exaurível, visto que todas as espécies protegidas estavam listadas no Apêndice 1 da CITES $^{163}$.

No que se refere ao nexo entre a medida questionada e a conservação das tartarugas marinhas, Índia, Paquistão e Tailândia alegam que a conclusão do relatório do painel no caso United States - Restrictions on Imports of Tuna (CE) seria aplicável neste caso. A referida conclusão reconhecia que uma medida adotada "so as to force other countries to change their policies, and that were effective only if such changes occurred, could not be primarily aimed at", and therefore did not 'relate to', conservation of an exhaustible natural resource". Observa-se que, embora o relatório não tenha sido aprovado pelas Partes Contratantes, a ele se faz referência neste ponto, como se, de fato, fosse uma decisão.

De acordo com os três países (OMC:WT/DS58/R,§3.250), o prazo de quarto meses que lhes havia sido concedido para implementação das redes com mecanismos de exclusão de tartarugas, independentemente da possibilidade de aquisição das redes pelos

\footnotetext{
162 Texto original da nota de rodapé: "See the following Appellate Body Reports: United States - Gasoline, adopted 20 May 1996, WT/DS52/AB/R, p. 23; Japan - Taxes on Alcoholic Beverages, adopted 1 November 1996, WT/DS8/AB/R, WT/DS10/AB/R, WT/DS11/AB/R, p. 12; and United States - Restrictions on Imports of Cotton and Man-made Fibre Underwear, adopted 25 February 1997, WT/DS24/AB/R, p. 16. See also Jennings and Watts (eds.), Oppenheim's International Law, 9th ed., Vol. I (Longman's, 1992), pp. 12801281; M.S. McDougal, H.D. Lasswell and J. Miller, The Interpretation of International Agreements and World Public Order: Principles of Content and Procedure (New Haven/Martinus Nijhoff, 1994), p. $184 ;$ I. Sinclair, The Vienna Convention on the Law of Treaties, 2nd ed. (Manchester University Press, 1984), $p$. 118; D. Carreau, Droit International (Editions A. Pedone, 1994), para. 369; P. Daillier and A. Pellet, Droit International Public, 5th ed. (L.G.D.J., 1994), para. 172; L.A. Podesta Costa and J.M. Ruda, Derecho Internacional Público (Tipografica Editora Argentina, 1985), pp. 109-110 and M. Diez de Velasco, Instituciones de Derecho Internacional Público, 11th ed. (Tecnos, 1997), p. 169".

${ }^{163}$ Cf. OMC (WT/DS58/AB/R:\$132), o excerto respectivo da decisão é o seguinte: "The exhaustibility of sea turtles would in fact have been very difficult to controvert since all of the seven recognized species of sea turtles are today listed in Appendix 1 of the Convention on International Trade in Endangered Species of Wild Fauna and Flora ('CITES'). The list in Appendix 1 includes 'all species threatened with extinction which are or may be affected by trade".
} 
países exportadores e da capacitação dos pescadores para sua utilização, resultaria em possibilidade de utilização incorreta da tecnologia imposta. Este fato teria sido reconhecido pelos próprios EUA em procedimento perante a Corte de Comércio Internacional de seu país (OMC:WT/DS58/R,§3.250).

Para os EUA, a interpretação do caso United States - Restrinction on Imports of Tuna (CE) não encontra suporte no texto do GATT, além de ser contrária à decisão do caso EUA - Gasolina.

Além disso, a proibição das importações de camarão dirigia-se a todos os países que não tivessem uma certificação de implementação de programa de proteção similar ao dos EUA. Deste modo, proibiam-se tanto as importações provenientes de eventuais países que utilizassem outros métodos que igualmente salvaguardassem as tartarugas marinhas quanto àquelas originadas de países que utilizavam a tecnologia imposta, mas não tinham a certificação.

Por sua vez, os EUA alegavam que a Seção 609 era claramente relacionada à conservação das tartarugas marinhas, com base na decisão do caso EUA - Gasolina (a medida deve ser "primarily aimed at" a conservação). Nesse sentido, por exemplo, tal seção demandava a realização de negociações de acordos bilaterais e multilaterais com vistas à proteção e à conservação das tartarugas marinhas, além de permitir apenas as importações de camarões pescados por meios que não prejudicavam as tartarugas.

Os EUA haviam verificado que a utilização de redes de arrastão na pesca do camarão era a principal causa de mortes induzidas por seres humanas das tartarugas marinhas. Por tal razão, impuseram, então, a utilização das redes com mecanismos de exclusão de tartarugas.

Índia, Paquistão e Tailândia discordavam de que a medida questionada fosse relacionada à conservação das tartarugas marinhas, apesar de considerarem que a Seção 609, como um todo, o fosse (OMC:WT/DS58/R,§3.254). Além disso, embora os EUA afirmassem que a maior causa de mortalidade das tartarugas era o uso das redes de arrastão na pesca do camarão, os três países afirmavam que a assertiva não procedia em seus respectivos territórios. Esta realidade, contudo, não havia sido considerada pelos EUA, de modo que recursos importantes para estes países eram gastos em redes em vez de em soluções para os verdadeiros fatores de risco. 
Para os referidos países, impedir as importações de camarão não faria com que o número de tartarugas marinhas aumentasse no mundo. De fato, a conservação das tartarugas somente seria atingida se outras nações modificassem suas políticas ambientais. A Malásia, por sua vez, afirma que a tecnologia imposta não é nem o único meio de proteção das tartarugas marinhas nem o mais eficiente. Nesse sentido, nem a UNCLOS nem o Agreement for the Implementation of the Provisions of UNCLOS Relating to the Conservation and Management of Stradding Stocks and Highly Migratory Fish Stocks de 1995 faziam qualquer tipo de referência àquela tecnologia (OMC:WT/DS58/R,§3.257).

Com relação a outras causas de mortalidade, os EUA afirmaram que "Article $X X(g)$ only required that a measures "related to" conservation of an exhaustible natural resource, but did no require that a measure address each and every threat to such resource” (OMC:WT/DS58/R,§3.259).

Por fim, com base na decisão do caso EUA - Gasolina, a Índia afirma que a medida questionada não pode ser considera relativa à conservação das tartarugas, pois ainda que a proibição das importações de camarões não fosse implementada, a Seção 609 continuaria a produzir efeitos.

O Órgão de Apelação cita a decisão do caso EUA - Gasolina, e decide que, pelo menos, a princípio a tecnologia imposta pelos EUA era relacionada à conservação das tartarugas, visto que i. a pesca comercial de camarão com redes de arrastão coincidia em áreas de alta mortalidade de tartarugas marinhas e ii. especialistas reconheciam a utilidade da tecnologia imposta pelos EUA para redução da mortalidade daquele recurso ${ }^{164}$.

De modo geral, a decisão do Órgão de Apelação, neste caso, foi severamente criticada pelos membros da OMC na reunião do OSC em que se discutiu a adoção dos relatórios do painel e do Órgão de Apelação.

Nesse sentido, no que se refere, em específico, à utilização do princípio da interpretação evolutiva, a Tailância declarou que "the Appellate Body's theory of "evolutionary" interpretation had been applied to render Article XX(b) and the

\footnotetext{
${ }^{164} \mathrm{Cf}$. OMC (WT/DS58/AB/R:§140), o excerto respectivo do relatório do Órgão de Apelação é o seguinte: "It is undisputed among the participants, and recognized by the experts consulted by the Panel, that the harvesting of shrimp by commercial shrimp trawling vessels with mechanical retrieval devices in waters where shrimp and sea turtles coincide is a significant cause of sea turtle mortality. Moreover, the Panel did "not question... the fact generally acknowledged by the experts that TEDs, when properly installed and adapted to the local area, would be an effective tool for the preservation of sea turtles".
} 
"necessary” test therein meaningless" (OMC:WT/DS/M/50,4). Para a Tailândia, a decisão do painel teria sérias implicações sistêmicas para a aplicação futura das regras da OMC. Neste sentido, ela poderia ter aberto as comportas para utilização abusiva das medidas ambientais relacionadas ao comércio. Por fim, a Tailândia manifestou sua esperança de que, no futuro, o Órgão de Apelação fosse mais sensível com relação aos limites impostos sobre sua jurisdição e demonstrasse mais respeito à sensibilidade dos membros.

O Paquistão, outro dos demandantes, também se manifestou sobre a utilização do princípio da interpretação evolutiva (OMC:WT/DS/M/50,5). Para este país, esta utilização seria uma "receita para aumentar e diminuir os direitos e as obrigações" dos membros, os quais haviam sido cuidadosamente negociados em sucessivas rodadas de negociação e, portanto, deveriam ser preservados. Do mesmo modo que a Tailândia, o Paquistão declarou que, com a interpretação adotada pelo Órgão de Apelação, o artigo XX(b) do GATT-1994 tornou-se sem sentido. Considerava também que a adoção da interpretação evolutiva prejudicava a previsibilidade do sistema de solução de controvérsias.

A Índia, terceiro demandante a se manifestar, também questionou a utilização da interpretação evolutiva, visto que isto não havia sido objeto de acordo entre os membros da OMC. Para a Índia, "reference to "contemporary concerns" to justify a changed interpretation of the words "exhaustible natural resources" had amounted to either an amendment or an authoritative interpretation of the existing agreement which could only be done by Members" (OMC:WT/DS/M/50,9). De acordo com a Índia, este fato teria sido reconhecido pelo Órgão de Apelação no caso US-Measure Affecting Imports of Woven Wool Shirts and Blouses from India (DS33).

As Filipinas, por sua vez, questionaram a utilização de normas produzidas fora do sistema multilateral de comércio, por não fazerem parte do direito da OMC (OMC:WT/DS/M/50,14). Além de afirmar que a decisão teria efeitos contrários aos desejados para proteção ambiental, visto que os membros passariam a tomar mais cuidado a se comprometerem com normas fora da OMC, as Filipinas ressaltam que:

"Members were subject to the provisions of the WTO law and the customary rules of international law. These treaties and declarations did not constitute part of customary international law.Members might have obligations under those treaties and declarations in other international forums but not in the WTO. The Philippines believed that, by referring to those treaties and 
declarations, the Appellate Body had not taken into consideration the basic customary international law principle of pacta sunt servanda. The body of international treaties did not constitute one single code of conduct, they were instead an accumulation, each treaty separate and independent from the other" (OMC:WT/DS/M/50,14).

A decisão foi criticada, ainda, pelo México, que não participou nem como terceira parte $(\mathrm{OMC}: \mathrm{WT} / \mathrm{DS} / \mathrm{M} / 50,13)$. Para este país, a interpretação adotada pelo Órgão de Apelação teria contrariado a letra e o espírito do artigo XX(g) do GATT-1994, e aquele órgão teria excedido a competência que havia recebido dos membros de forma prejudicial ao sistema de solução de controvérsias ${ }^{165}$.

Dos membros que se manifestaram durante a reunião, apenas a Austrália ${ }^{166}$ e a Suíça ${ }^{167}$ reconheceram a correção da decisão e ressaltaram os aspectos ambientais dela decorrentes. Hong Kong, por sua vez, demonstrou-se satisfeito com a decisão, com a ressalva de que esta implica em sobreposição das alíneas $b$ e $g$ do artigo XX do GATT1994 (OMC:WT/DS/M/50,15).

165 Excerto respectivo da minuta da reunião, cf. WTO (WT/DS/M/50:13): “In Mexico's view, this interpretation was contrary to the letter and spirit of that sub-paragraph, and the Appellate Body had overstepped its authority in a manner that was damaging to the dispute settlement system".

${ }^{166} \mathrm{Cf}$. WTO (WT/DS/M/50:13): "It would be unfortunate if this case was represented as evidence of a conflict between trade and environmental objectives. A careful analysis of the issues had demonstrated that this was not so. (...) In particular, the Appellate Body had affirmed that the WTO rules appeared to be compatible with the Rio Declaration's emphasis on the importance of international cooperation to address transboundary and global environmental problems. The findings had confirmed that a key consideration in the determination of the existence of unjustifiable discrimination under Article XX was whether cooperative approaches had been pursued, or whether a measure reflected a unilateral, non-consensual approach to addressing the environmental problem of concern. In this respect, the WTO rules seemed to strongly reinforce the importance of intergovernmental dialogue on global and transboundary environmental problems. This was a key ingredient in avoiding unnecessary or inappropriate trade-restrictive measures".

${ }^{167}$ Cf. WTO (WT/DS/M/50:9): “The interpretation of Article XX by the Appellate Body had provided some useful interpretative aspects concerning the amount of freedom for Members in ensuring conservation of exhaustible natural resources. In particular, her delegation welcomed the fact that the Appellate Body had specifically referred to international environmental legislation in reaching its conclusion that sea turtles were exhaustible natural resources in the sense of Article $X X(g)$ and therefore they were covered by special measures of protection. This openness had demonstrated that the multilateral trading system was not closed with regard to other legal regulations at the multilateral level'. 


\subsection{Classificação da argumentação utilizada para justificação externa}

A partir da exposição realizada no item anterior, é possível organizar os argumentos apresentados pelas partes da disputa e pelos decisores nas seguintes categorias: tratados, costume, princípios, jurisprudência, doutrina e afirmações empíricas.

A categoria "tratados" incluiu todos aqueles instrumentos que preenchiam os requisitos do artigo 2:1(a) da Convenção de Viena sobre Direito dos Tratados, o qual estatui: “'treaty' means an international agreement concluded between States in written form and governed by international law, whether embodied in a single instrument or in two or more related instruments and whatever its particular designation”. Dentre outros, foram incluídos os seguintes documentos nesta categoria: acordos do sistema multilateral de comércio, UNCLOS e CITES.

A definição de costume, por sua vez, é dada pelo Estatuto da Corte Internacional de Justiça (CIJ), o qual o considera uma das fontes de direito internacional: evidence of a general practice accepted as law [artigo 38.1(b)]. A própria jurisprudência da Corte desenvolveu os elementos específicos para caracterização de um costume internacional, quais sejam: duração, uniformidade (ou consistência da prática), observação generalizada e opinio juris et necessitatis ${ }^{168}$. Devido à dificuldade de caracterização de costume, apenas aqueles expressamente referidos como tal foram incluídos nesta categoria. $\mathrm{Na}$ prática, foram apenas os costumes relativos à interpretação, de forma a cumprir o requisito do artigo 3.2 do Entendimento sobre Solução de Controvérsias.

No que se refere à categoria seguinte, "princípios", foram incluídos tanto aqueles derivados dos ordenamentos nacionais ${ }^{169}$ quanto os originados no plano internacional. Segundo M. N. SHAW (1997:78),

\footnotetext{
${ }^{168} \mathrm{O}$ caso Military and Paramilitary Activities in and against Nicaragua apresentado perante a CIJ, por exemplo, é paradigmático na questão. Também a doutrina refere-se à questão, v., por exemplo, I. BROWNLIE (1998:4-11), N. G. Dinh, P. DAillier e A. Pellet (2003:328-354) e M. N. ShaW (2001:56-73).

${ }^{169}$ Com relação ao primeiro conjunto de princípios, o qual compreende os que nascem dos ordenamentos internos dos Estados para serem transpostos para o plano internacional, de acordo com N. G. DINH, P. DAillier e A. Pellet (2003:358): "Só podem ser transpostos para a ordem jurídica internacional os princípios comuns aos diferentes sistemas jurídicos nacionais (...). É necessário e suficiente que um princípio interno se verifique na maior parte dos sistemas jurídicos, não em todos". Esta interpretação encontra suporte na decisão da CIJ no caso South-West África. Os mesmo autores, no entanto, continuam e afirmam que a
} 
"most writers are prepared to accept that the general principles do constitute a separate source of law but of fairly limited scope, and this is reflected in the decisions of the Permanent Court of International Justice. It is not clear, however, in all cases, whether what is involved is a general principle of law appearing in municipal systems or a general principle of internacional law".

Com a abordagem adotada nesta pesquisa, portanto, incluem-se as duas possibilidades. Ademais, observa-se que, embora alguns autores considerem que os princípios constituem etapa transitória do direito internacional, visto que suas repetição e observância generalizadas levam à caracterização como costume, nesta pesquisa se adota a posição de que os princípios têm estatuto próprio. Esta posição segue a linha reconhecida pelo Estatuto da CIJ, o qual reconhece os princípios gerais de direito internacional como uma das fontes a serem utilizadas pela corte em suas decisões, de acordo com o artigo 38:1(c) do referido instrumento. Na prática, foram incluídos os princípios de interpretação, como interpretação efetiva, e de devido processo - o qual resultou da interpretação do recurso feito pelos EUA à justiça no procedimento.

$\mathrm{Na}$ categoria jurisprudência, foram incluídas todas as decisões de cortes e tribunais internacionais, laudos arbitrais de procedimentos inter-estatais e relatórios dos painéis ou do Órgão de Apelação da OMC.

Os documentos sem força vinculante emitidos por Estados, no âmbito internacional, foram incluídos na categoria específica, "declarações". Deste modo, a menção à Agenda 21 foi incluída nesta categoria.

generalidade não é um requisito que sempre prevaleceu. Nesse sentido, citam posição do Tribunal de Justiça da União Européia, o qual aplica simultaneamente princípios gerais de direito em vigor em todo e qualquer sistema jurídico, seja fora ou dentro de seu âmbito. I. BROWNLIE (1998:16) ressalva, contudo, que: "It would be incorrect to assume that tribunals have in practice adopted a mechanical system of borrowing from domestic law after a census of domestic systems. What has happened is that international tribunals have employed elements of legal reasoning and private law analogies in order to make the law of nations a viable system for application in a judicial process. Thus, it is impossible, or at least difficult, for state practice to evolve the rules of procedure and evidence which a court must employ. Na international tribunal chooses, edits, and adapts elements from better developed systems: the result is a new element of international law the content of which is influenced historically and logically by domestic law". Além do requisito da generalidade, impõe-se ainda o requisito de que os princípios sejam transponíveis para o plano do direito internacional - o que será verificado por meio da análise das diferenças e semelhanças entre as estruturas do direito interno e do direito internacional. 
Os documentos resultantes do processo de tomada de decisão de organizações internacionais, como resoluções, foram incluídos na categoria "documentos de organizações internacionais".

Observa-se que os elementos inclusos nas categorias "tratados", "costume", "princípios" e "jurisprudência" foram alocados entre as subcategorias "sistema multilateral de comércio" e "outros", conforme sua procedência.

No que se refere à categoria "doutrina", não se estabeleceu nenhum critério qualitativo para a caracterização dos elementos nela incluídos. De fato, o critério adotado para inclusão nesta categoria foi a forma de publicação. Neste sentido, incluíram-se manuais, livros especializados, artigos em revista e relatórios de pesquisa e de organizações internacionais (originados do trabalho de especialistas, grupos de trabalho, painéis etc).

Por fim, consideraram-se "afirmações empíricas" todas aquelas relativas a fatos da realidade (como características de um determinado ente, por exemplo), constatações científicas, fatos históricos, referências a ordenamentos jurídicos internos (não referentes a princípios) e demais assertivas não inclusas nas categorias anteriores. Assim, foi incluída nesta categoria, por exemplo, as características das tartarugas e do ar.

Dentre as categorias acima, são consideradas referentes a elementos normativos as seguintes: tratados, costume, princípios e jurisprudência. Esta acepção está relacionada com o artigo 38 do Estatuto da CIJ, o qual estabelece as fontes de direito internacional.

Não obstante o referido artigo também inclua doutrina, como fonte subsidiária, devido à controvérsia sobre seu status, optou-se por não identificá-la como elemento normativo. Como também ocorre com afirmações empíricas.

O quadro abaixo ilustra a ocorrência dos elementos identificados, em cada caso, independentemente de sua freqüência: 


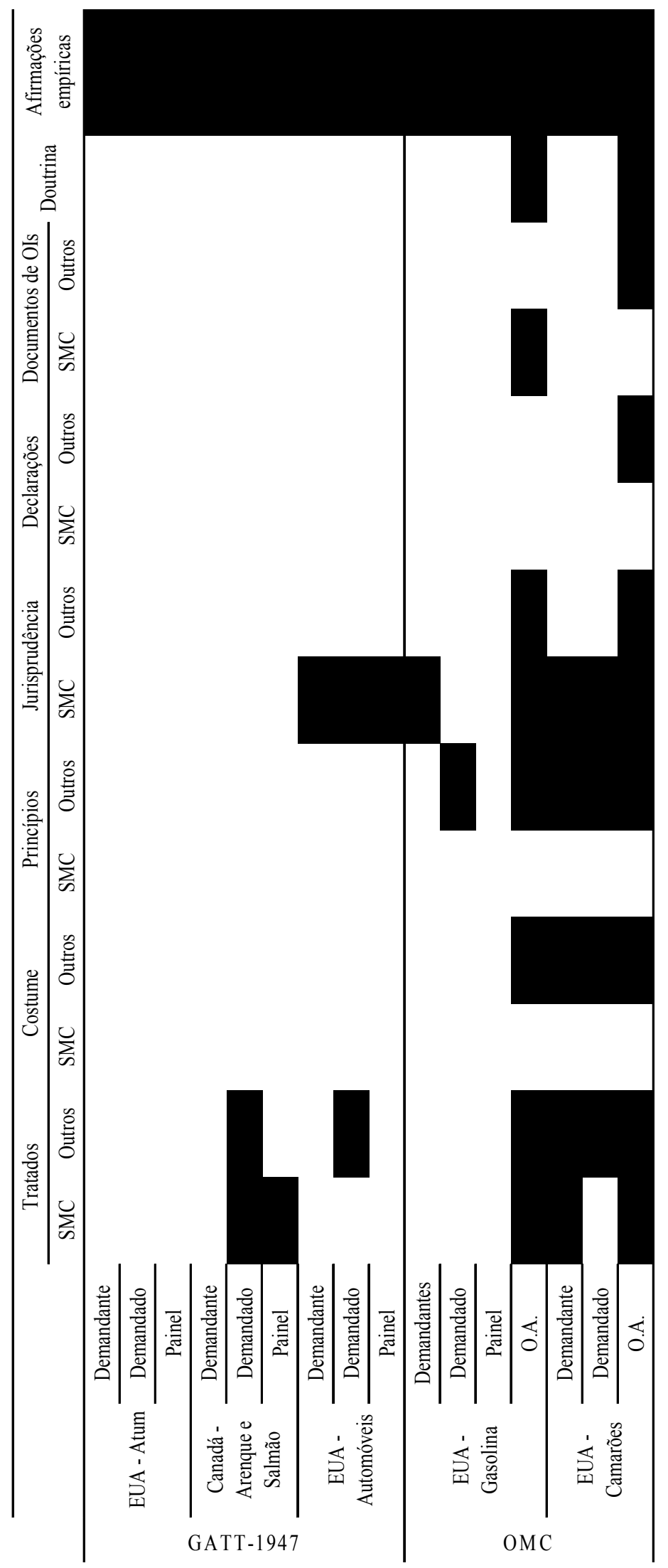

Quadro 3: Classificação dos argumentos utilizados para justificação das medidas questionadas com base no artigo XX(g) do GATT

Legenda: SMC: sistema multilateral de comércio; OIs: organizações internacionais; O.A.: Órgão de Apelação. 


\subsection{Conclusão}

Conforme evidenciado no quadro acima, verifica-se que houve alteração nas fontes utilizadas pelas partes da disputa e pelos decisores na justificação de suas posições. Em específico, é possível afirmar que, enquanto no GATT-1947, prevaleciam os argumentos relativos a afirmações empíricas e a elementos normativos do próprio sistema (em menor grau), na OMC, o recurso a elementos normativos foi incrementado.

Embora uma decisão jurídica possa ter como objeto de análise exclusivamente fatos, o recurso mais constante a elementos normativos diversos implica na maior juridicidade das decisões da OMC em face daquelas do GATT-1947.

Tal como explanado no capítulo 1, diferentes mecanismos de solução de controvérsias detêm graus diversos de juridicidade - a qual se reflete nas manifestações que deles emanam em cada disputa. Desta forma, os mecanismos com menor grau de juridicidade, ou seja, os mecanismos políticos ou diplomáticos, tendem a ter uma linguagem específica diferente da dos mecanismos em estágio mais avançado do processo de juridicização. Neste sentido, os primeiros tendem a utilizar a linguagem diplomática ${ }^{170}$, enquanto os últimos recorrem à linguagem jurídica.

O objetivo do discurso diplomático não é tanto buscar sua legitimação com referências a normas que regulamentem o comportamento dos sujeitos envolvidos, mas manifestar o acordo negociado entre estes. Em decorrência, o discurso diplomático costuma ser marcado pela ambigüidade e pela generalidade de seus termos, visto que esta possibilita sua aceitação por maior número de destinatários.

\footnotetext{
${ }^{170}$ E. M. CARVAlHo (2005:92) especifica que, como instrumento da negociação internacional, "a linguagem diplomática deve estar a serviço das estratégias de composição de diferenças de posições expressadas pelos atores da cena internacional - e isto se aplica também ao próprio discurso diplomático, aqui considerado como expressão lingüística, seja escrita ou oral, da linguagem diplomática, e que não coincide com o discurso jurídico-convencional. Eis por que a ambigüidade do discurso diplomático, antes de ser um vício que se deve evitar a qualquer custo, pode se apresentar como um tipo de virtude, uma competência semiótica na qual se espera serem versados os negociadores. Ambigüidade da palavra que permite ao seu emissor situar-se estrategicamente entre o consenso e o dissenso, entre o "não" e o "sim", de maneira a conceder-lhe uma margem de ação política sem pô-lo em contradição com seus termos, preservando a sua credibilidade de negociador. "It resorts to a flexible phraseology that would not preclude a change of position in the future, and favors understatement", diz Alexander Ostrower".
} 
A linguagem jurídica, por outro lado, seria aquela elaborada "desde a perspectiva do direito estabelecido para regular as relações jurídicas entre sujeitos de direito internacional" (CARVAlHo:2005, 78). De fato, o discurso jurídico da decisão emanada de Terceiro, enquanto marco da passagem da autotutela para a heterotutela, tem seu eixo na referência à norma cuja observância se busca.

A partir da análise das decisões a que se acaba de proceder, é possível observar que houve incremento na utilização de elementos normativos utilizados para a motivação das decisões da OMC em relação àquelas do GATT-1947.

Este fenômeno reflete-se, por exemplo, na caracterização da exauribilidade dos recursos naturais.Neste sentido, enquanto, no caso EUA - Automóveis, do GATT-1947, o painel fez a relação da gasolina com o petróleo, cujas reservas eram finitas;no caso EUA Camarões, o Órgão de Apelação indicou que as espécies de tartarugas marinhas estavam listadas no Apêndice 1 da CITES.

Deste modo, se a relação com a norma é fator característico e representativo da juridicidade das decisões, observa-se que as decisões da OMC apresentaram maior juridicidade em relação às do GATT-1947. 


\section{CONSIDERAÇÕES FINAIS}

O objetivo da presente pesquisa consistiu em analisar o processo de juridicização do sistema multilateral de comércio. Nesta atividade, aplicou o modelo teórico de K. W. Aввотт et al (2000) e confrontou os resultados desta aplicação com a prática do sistema de solução de controvérsias do GATT-1947 e da OMC.

O capítulo 1 destinou-se a apresentar o modelo teórico desenvolvido por $\mathrm{K}$. W. Аввотт et al (2000). De acordo com esta teoria, as características do órgão ao qual se delega a autoridade para solucionar as controvérsias que surgem no âmbito do sistema são elemento decisivo para definição do grau de juridicidade. Assim, quanto mais houver acesso ao sistema, independência do órgão e efeito direto das decisões deste emanadas, mais juridicidade terá um determinado sistema. Como demonstrado, somente o processo de institucionalização dos elementos de análise os tornam relevantes para o modelo.

No capítulo 2, tal modelo teórico foi aplicado para análise do sistema multilateral de comércio. De acordo com as conclusões deste capítulo, é possível verificar que houve avanço no processo de juridicização com a adoção dos resultados da Rodada Tóquio, momento em que se procedeu, pela primeira vez, à institucionalização de todos os mecanismos de solução de controvérsias existentes no sistema.

Não obstante, ao longo de toda a vigência do sistema, a competência para solução de controvérsias foi atribuída a órgãos políticos dos quais participavam as partes da controvérsia - as Partes Contratantes (ou Conselho, entre sessões das Partes Contratantes), no âmbito do GATT-1947, e o OSC na OMC.

O iter seguido para a adoção de decisão por estes órgãos, contudo, sofreu alteração significativa ao longo do processo. Neste sentido, enquanto as partes negociavam o relatório nos primórdios do sistema multilateral de comércio; na OMC, existe um Órgão de Apelação competente para se manifestar sobre questões legais dos relatórios dos painéis. Observa-se, contudo, que os relatórios destes órgãos auxiliares nunca tiveram 
força obrigatória em si, razão pela qual sempre precisaram de sua aprovação pelo órgão político de tomada de decisão.

Observa-se que os dois primeiros casos analisados seguiram os procedimentos previstos pelos resultados da Rodada Tóquio. Por sua vez, o terceiro caso foi regido pelos procedimentos da decisão de 1989 - a regulamentação do GATT-1947 mais semelhante àquela vigente na $\mathrm{OMC}$.

Após a aplicação do modelo teórico para análise do sistema multilateral de comércio, o capítulo 3 visava a comprovar na prática o reflexo do processo de juridicização observado. O capítulo partia do pressuposto de que o grau de juridicidade de um sistema de solução de controvérsias é refletido em suas manifestações ou decisões. Deste modo, buscava comprovar se as decisões da OMC teriam grau de juridicidade similar àquelas do sistema anterior que haviam sido analisadas.

As conclusões do capítulo 3 foram em sentido contrário ao esperado pela aplicação do modelo teórico analisado. Assim, no GATT-1947, prevaleciam os argumentos relativos a afirmações empíricas e a elementos normativos do próprio sistema (em menor grau) na justificação da subsunção da cláusula "relativas à conservação de recursos naturais exauríveis". Por outro lado, na OMC, o recurso a elementos normativos foi incrementado e tornou-se mais complexo, não obstante a competência para solução de controvérsias ainda seja atribuída a um órgão político.

O fenômeno de recurso mais freqüente a elementos normativos justificação das decisões prolatadas foi interpretado, nesta pesquisa, como maior grau de juridicidade, em razão da ligação mais próxima a normas.

Nota-se que este recurso mais freqüente a elementos normativos de diversas ordens inicia-se na manifestação do Órgão de Apelação no caso EUA - Gasolina, como sintetizado no Quadro 3 acima. De fato, uma das diferenças entre a regulamentação da Decisão de 1989 e a do Entendimento sobre Solução de Controvérsias consiste na criação do Órgão de Apelação por este.

O Entendimento sobre Solução de Controvérsias atribui ao Órgão de Apelação competência para conhecimento de aspectos legais dos relatórios dos painéis, exclusivamente. Além disso, o artigo 3.2 do mesmo instrumento dispõe que os acordos 
analisados devem ser interpretados de acordo com as regras de interpretação do direito internacional consuetudinário ${ }^{171}$.

Sem que o Entendimento sobre Solução de Controvérsias tenha definido quais são estas regras de interpretação, verifica-se que as mais diversas regras reconhecidas pelo direito internacional consuetudinário e por princípios têm sido utilizadas para justificar as decisões dos órgãos auxiliares do OSC.

Esta utilização é ilustrada pelo relatório do Órgão de Apelação no caso EUA Camarões. Neste documento, o Órgão de Apelação aplicou os princípios da interpretação efetiva e da interpretação evolutiva desenvolvidos pelas decisões da CIJ. Por meio da aplicação destes princípios, possibilitou-se o recurso aos mais diversos elementos normativos para justificação da decisão, como, por exemplo, a UNCLOS, a CITES e a Convenção sobre Diversidade Biológica.

Ressalta-se que a referência a normas produzidas fora do âmbito do sistema multilateral de comércio havia sido expressamente rejeitada no caso Canadá - Arenque e Salmão, como indicado no capítulo 3. Ora, não houve, como demonstrado no Apêndice D, nenhuma alteração substantiva nos termos de referência dos órgãos auxiliares na passagem do GATT-1947 para a OMC. Isto leva a concluir que ocorreu uma modificação na interpretação dada aos termos de referência destes órgãos, com implicações para a definição de sua jurisdição.

Reconhece-se que a utilização destas regras foi objeto de severa crítica por parte de membros da OMC. A análise das decisões permitiu identificar, contudo, que o artigo 3.2 do Entendimento sobre Solução de Controvérsias começou a ser utilizado também como escudo contra as investidas políticas dos membros sobre o conteúdo do relatório. Esta assertiva é ilustrada pelo seguinte excerto retirado do relatório do painel do caso EUA - Camarões (§6.5):

"The United States also claims that the Panel adopted a new test based on the Panel's view of the object and purpose of the Article $X X$ chapeau. However, this mischaracterizes our findings, which do not rely solely on the object and purpose of Article XX. They are based on an analysis, pursuant to Article 31(1) of the Vienna

\footnotetext{
171 Ainda que haja uma diferença nos sentidos presentes nas traduções oficiais, conforme demonstrado na introdução, a prática demonstra que o sentido previsto na versão da língua inglesa prevalece.
} 
Convention on the Law of Treaties (1969), of the ordinary meaning of the terms of the chapeau of Article XX, taken in their context and in the light of the object and purpose of the WTO Agreement. Moreover, in our reasoning, we rely also on general principles of public international law such as pacta sunt servanda. Consequently, our findings are the result of the application of interpretative methods required by Article 3.2 of the DSU. In our view, our process of interpretation of Article XX in this case does not add to Members' obligations in contravention of Article 3.2 of the DSU'.

No procedimento de apelação, como não há a previsão de uma etapa preliminar de revisão do relatório a ser emitido, o membro não tem acesso a seu conteúdo e, portanto, não pode se manifestar sobre ele. Assim, apenas durante a reunião do OSC em que se discute a adoção do relatório, os membros podem manifestar sua posição. Neste momento, contudo, não é mais possível alterar o conteúdo do relatório, de modo que sua aprovação torna-se quase que inevitável - ela não ocorrerá apenas se o consenso negativo for alcançado.

Verifica-se, portanto, a importância das regras relativas à conformação do Órgão de Apelação, à interpretação e à tomada de decisão no processo de juridicização do sistema multilateral de comércio. Estes fatores conduziram os membros, na prática, à aceitação do discurso jurídico presente nos relatórios dos órgãos auxiliares.

De forma complementar a esta aceitação condicionada, os membros passaram a ter a iniciativa de utilização deste tipo de discurso jurídico no âmbito do OSC, ainda que este seja um órgão político de tomada de decisão. Assim, a comparação das defesas apresentadas nos casos EUA - Gasolina e EUA - Camarões ilustra a alteração dos elementos utilizados pelos membros em suas manifestações.

Observa-se, ainda, que os EUA chegaram a recorrer à "justiça" entre as partes nos procedimentos - o que somente pode ser interpretado como recurso ao princípio do devido processo. Ora, a utilização de princípios não é expressamente prevista pelos acordos abrangidos.

Observa-se que, em nenhuma das disputas apresentadas ao OSC, no período entre 1995 e 2006, em que houve apelação, as partes desistiram do procedimento de apelação para alcançarem acordo mutuamente satisfatório e negociado bilateralmente.

Ao longo deste processo, contudo, alguns membros começaram a se mostrar insatisfeitos com a atuação dos órgãos auxiliares do OSC, em especial, o Órgão de 
Apelação - como demonstrado com os comentários dos membros na reunião em que discutiu a aprovação dos relatórios do caso EUA - Camarões no capítulo 3.

Como resultado, no âmbito do processo de revisão do Entendimento sobre Solução de Controvérsias da Rodada Doha de negociações comerciais multilaterais, em dezembro de 2002, os EUA e o Chile apresentaram proposta conjunta para maior flexibilização dos procedimentos de solução de controvérsias (TN/DS/W/28).

Dentre os elementos previstos na proposta, incluem-se:

1. Criação de fase de revisão preliminar do relatório do Órgão de Apelação, para que as partes possam se manifestar sobre o seu conteúdo e contribuir para a versão final do relatório;

2. Instituição de mecanismo que possibilite, às partes, após a revisão preliminar do relatório, a exclusão, por acordo mútuo, de decisões presentes no documento que as partes julguem não ser necessárias ou que não as auxiliem a resolver a disputa, de modo a permitir que as partes mantenham o controle sobre os termos de referência;

3. Elaboração de disposição que permita a adoção parcial dos relatórios, por meio da qual o OSC poderia se recusar a adotar certas partes dos relatórios e, ainda assim, dar uma recomendação ou decisão que ajude as partes a resolverem a disputa;

4. Possibilidade de suspensão dos procedimentos do painel e do Órgão de Apelação, por acordo entre as partes da disputa; e

5. "Providing some form of additional guidance to WTO adjudicative bodies concerning (i) the nature and scope of the task presented to them (...) and (ii) rules of interpretation of the WTO agreements".

Esta proposta foi rejeitada por diversos membros nas sessões especiais do OSC destinadas à negociação da revisão do Entendimento e foi abandonada ao longo das sessões seguintes. Esta rejeição da proposta dos EUA e do Chile também evidencia que o discurso jurídico tem sido aceito pelos membros no âmbito do OSC.

Diante dos argumentos apresentados, é possível verificar, portanto, que o processo de juridicização no âmbito do sistema de solução de controvérsias da OMC foi conduzido por dois fatores. De um lado, a partir das normas postas, o Órgão de Apelação adotou discurso jurídico que, embora não condizente com o caráter político do OSC, teve 
de ser aceito, como resultado das regras relativas à tomada de decisão e à interpretação previstas no Entendimento sobre Solução de Controvérsias. Por outro, os próprios membros da OMC incorporaram, até certo grau, tal discurso em suas posições.

Observa-se que tais fatores se retroalimentam. Se, a princípio, o discurso jurídico foi trazido para o OSC pelos relatórios do Órgão de Apelação, para, somente depois, ser incorporado pelos membros da OMC; agora, estes mesmos membros, que são as partes das controvérsias apresentadas, passam a utilizar o mesmo discurso jurídico em suas defesas.

A partir dos elementos apresentados, conclui-se, portanto, que, apesar de o modelo teórico de K. W. AвВотт et al (2000) ser útil para demonstrar que a competência para solução de controvérsias no âmbito da OMC continua a ser imputada a um órgão político de tomada de decisão, ele não é suficiente para dar conta do fenômeno analisado.

A razão para esta insuficiência deve-se ao enfoque excessivo no processo de institucionalização e no órgão formalmente competente para solução de controvérsias. Este enfoque não permite que sejam refletidas no processo as alterações ocasionadas por outros elementos, como foi o caso, na presente pesquisa, das regras relativas à conformação dos órgãos auxiliares - em especial, o Órgão de Apelação-, à interpretação e à tomada de decisão.

A atuação do Órgão de Apelação parece ser determinante neste processo, visto que suas decisões se mostraram as mais elaboradas. De fato, há autores, como H. R. FABRIZ (2005) os quais declaram que o Órgão de Apelação assumiu papel muito maior do que a função que se lhe havia sido atribuída pelos negociadores da Rodada Uruguai. Há evidências de que esta afirmação procede, mas a constatação da consistência do comportamento de tal órgão e de sua influência sobre os painéis e as próprias partes só pode dar-se por meio de pesquisa empírica mais ampla.

Em suma, constata-se que a análise do processo de formação de sistemas jurídicos no âmbito internacional com enfoque em tratados e institucionalização não é suficiente para explicar o seu objeto de estudo. Como demonstrado, na prática, a estrutura 
estabelecida ganha vida própria e passa a contribuir para o seu próprio aprimoramento, diante da não rejeição daqueles que integram o sistema ${ }^{172}$.

No que se refere ao problema que deu origem a esta pesquisa, ressalta-se a alteração quanto à definição jurisdição dos órgãos auxiliares. Esta alteração pode ser verificada a partir do cotejo da decisão do painel no caso Canadá - Arenque e Salmão de não fazer nenhum tipo de referência aos tratados internacionais que haviam sido citados pelo Canadá em face das duas decisões apresentadas perante a $\mathrm{OMC}$, em especial, a do caso EUA - Camarões. Neste caso, o Órgão de Apelação recorreu a diversos princípios de interpretação, cuja utilização foi justificada com base em decisões da CIJ e em doutrina, e a diversas convenções que não fazem parte do sistema multilateral de comércio - como, por exemplo, a UNCLOS e a CITES.

Observa-se que esta alteração não foi ocasionada por eventual mudança dos termos de referência dos órgãos auxiliares, visto que estes foram praticamente os mesmos para todas as disputas (V. apêndice 5). Deste modo, embora a competência e a jurisdição do painéis tenham permanecido as mesmas no GATT-1947 e na OMC, a jurisdição passou a ser interpretada de modo diverso na OMC, ainda que sem disposição específica pelas partes da disputa e dos membros da OMC.

Ressalta-se que os resultados obtidos por esta pesquisa decorrem, diretamente, das fontes que puderam ser analisadas. $\mathrm{O}$ acesso a documentos que não se encontravam disponíveis pode complementar os dados apresentados em momento posterior.

Por fim, a autora manifesta sua esperança de que esta dissertação tenha fornecido alguns elementos que contribuam para a elucidação do problema que lhe deu origem. Relembra-se, neste sentido, que esta pesquisa constitui o primeiro passo na definição da relação das normas produzidas no âmbito do sistema multilateral de comércio com aquelas originadas em outros foros.

\footnotetext{
172 Reconhece-se, contudo, a precariedade deste processo diante da ausência de regras mais fortes para garanti-lo. Neste sentido, a influência política do OSC pôde ser exercida sobre o Órgão de Apelação no caso European Communities - Measures affecting asbestos and products containing asbestos (DS135) no que se refere ao recebimento de manifestações escritas de amicus curiae. Neste caso, o Órgão de Apelação estabeleceu um procedimento específico por meio do qual aceitaria tais manifestações. Logo depois, o OSC realizou uma reunião extraordinária para discutir, especificamente, esta questão. Os membros criticaram severamente a decisão do Órgão de Apelação; e, quando o Órgão de Apelação manifestou-se sobre o recebimento das manifestações, declarou não ter recebido nenhum.
} 


\section{REFERÊNCIAS BIBLIOGRÁFICAS}

Аввотт, K. W. et al. Legalization and World Politics. International Organization, v. 54, n. 3, p. 401-419, Summer 2000.

Аввотт, K. W. The Many Faces of International Legalization. American Society of International Law Proceedings of the Annual Meeting, v. 92, p. 57-63, 1998.

Acordo Geral sobre Comércio e Tarifas, de 1947. Disponível em: $<$ http://www.wto.org/english/docs_e/legal_e/legal_e.htm>. Acesso em: 21 jan. 2007.

AKeHurst, M. Jurisdiction in International Law. British Yearbook of International Law, v. 46, p. 145-257, 1974.

ALEXY, R. A theory of legal argumentation: the theory of rational discourse as theory of legal justification. Oxford: Clarendon Press, 1989.

Amaral JR, A. (coord.). OMC e o Comércio Internacional. São Paulo: Aduaneiras, 2002.

Amaral JR, A. A Organização Mundial do Comércio: estrutura institucional e solução de controvérsias. Revista do Instituto dos Advogados de São Paulo, v. 7, n. 14, p. 127-136, jul.-dez. 2004.

Amaral Jr, A. et al. A Reforma do Sistema de Solução de Controvérsias da OMC e os Países em Desenvolvimento. São Paulo: IDCID, 2006.

AnghiE, A. Cultural difference and international law: the league of nations and its two visions of the Nation-State. ICCLP Review, v. 5. n. 2, p.5-15, Oct. 2002.

Aron, R. Paz e Guerra entre as Nações. Brasília: Editora Universidade de Brasília: Imprensa Oficial do Estado de São Paulo: Instituto de Pesquisa de Relações Internacionais, 2002.

Ata final que incorpora os Resultados da Rodada Uruguai, de 15 de abril de 1994. Disponível em: <http://www.wto.org/english/docs_e/legal_e/legal_e.htm>. Acesso em: 21 jan. 2007.

BARDin, L. Análise de Conteúdo. Lisboa: Edições 70, 1995.

BlacketT, A. The International Law of Trade: Mapping the Equilibrium Line: Fundamental Principles and Rights at Work and the Interpretative Universe of the World Trade Organization. Saskatchewan Law Review, v. 65, s/n, p. 369/392, 2002. 
BORN, G. Reflections on Judicial Jurisdiction in International Cases. International \& Comparative Law Quarterly, v. 17, p. XX-XX, 1987.

BRADFORD, W. C. (2004). The changing laws of war:do we need a new legal regime after September 11? 'The duty to defend them': a natural law justification for the Bush Doctrine of preventive war. Notre Dame Law Review, v. 79, p. 1365-1492, July 2004.

Brasil. Decreto n. 1355, de 30 de dezembro de 1994. Promulga a Ata Final que Incorpora os Resultados da Rodada Uruguai de Negociações Comerciais Multilaterais do GATT. Lex: Legislação Federal, s/v, s/n, p. 2392-2902, [2005].

Decreto n. 313, de 30 de julho de 1948. Disponível em:

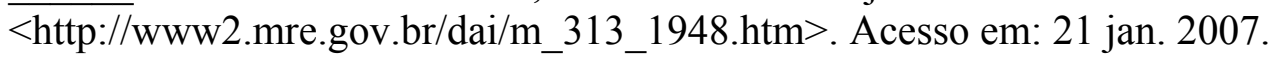

Brownlie, I. Principles of Public International Law. 5. ed. Oxford: Oxford University Press, 1998.

Busch, M.; Reinhardt, E. Developing Countries and GATT/WTO Dispute Settlement. Journal of World Trade, v. 37,n. 4, p. 719-735, 2003.

CAHIER, P. L'ordre juridique interne dês organizations internationales. In: DUPUY, R.-J. (coord.). Manuel sur Les Organisations Internationales. 2. ed. London: Kluwer Law International, p. 377/397, 1998.

CARdoso, C. Batalhas jurídicas: inserção do país no comércio mundial leva escritórios a se especializar para enfrentar os estrangeiros. Folha de São Paulo, São Paulo, 17 abr. 2005.

Carta das Nações Unidas, 26 june 1945. Disponível em: <http://www.icjcij.org/icjwww/ibasicdocuments/unchart.pdf>. Acesso em: 21 jan. 2007.

Carta de Havana, de abril de 1948. Disponível em: $<$ http://www.wto.org/english/docs_e/legal_e/havana_e.pdf $>$. Acesso em: 21 jan. 2007.

Carvalho, E. M. O Discurso Jurídico-Decisório da Organização Mundial do Comercio: uma analise semiótica dos relatórios do Órgão de Apelação.Tese de Doutorado defendida junto ao Departamento de Direito Internacional da Faculdade de Direito da USP. 14 de julho de 2005. 284p.

Casella, P. B. União Européia: Instituições e Ordenamento Jurídico. São Paulo: Editora LTR, 2002.

CASTEL, J.-G. The Uruguay Round and the Improvements to the GATT Dispute Settlement Rules and Procedures. International and Comparative Law Quarterly, v. 38, s/n, p. 834-849, 1989.

CAstillo, A. Z. Proceso, autocomposición y autodefensa: contribución al estudo de los fines del processo. 2. ed. Cidade do México: Universidad Nacional Autónoma de México, 1970.

Charnovitz, S. Rethinking WTO Trade Sanctions. The American Journal of International Law, v. 95, s/n, p. 792-832, oct. 2001. 
CIJ. Aegean Sea Continental Shelf. Jurisdiction of the Court. Demandante: Grécia. Demandado: Turquia. Den Haag. 19 dec. 1978. Disponível em: <http://www.icjcij.org/icjwww/icases/igt/igt_ijudgment/igt_ijudgment_19781219.pdf $>$. Acesso em: 21 jan. 2007.

Arbitral Award of 31 July 1989. Judgment of 12 November 1991. Demandante: Guiné Bissau. Demandado: Senegal. Den Haag. 12 nov. 1991. Disponível em: $<$ http://www.icj-

cij.org/icjwww/icases/igbs/igbs_isummaries/igbs_isummary_19911112.htm>. Acesso em: 21 jan. 2007.

Barcelona Traction, Light and Power Company, Limited. Demandante: Bélgica. Demandado: Espanha. Den Haag. 1961. Disponível em: <http://www.icjcij.org/icjwww/idecisions.htm>. Acesso em: 21 jan. 2007.

Military and Paramilitary Activities in and against Nicaragua. Jurisdiction of the Court and Admissibility of the Application. Demandante: Nicarágua. Demandado: EUA. Den Haag. 26 nov. 1984. Disponível em: <http://www.icjcij.org/icjwww/idecisions.htm>. Acesso em: 21 jan. 2007.

. Military and Paramilitary Activities in and against Nicaragua. Merits. Demandante: Nicarágua. Demandado: EUA. Den Haag. 27 june 1986. Disponível em: $<$ http://www.icj-cij.org/icjwww/icases/inus/inus_ijudgment/inus_ijudgment_19860627 .pdf $>$. Acesso em: 21 jan. 2007.

. Nottebohm. Demandante: Liechtenstein. Demandado: Guatemala. 1951-1955.

. South-West Africa. Judgment of 18 July 1966 (summary). Demandante: Etiópia. Demandado: África do Sul. Den Haag. 18 july 1966. Disponível em: <http://www.icjcij.org/icjwww/idecisions/isummaries/ilsaesasummary660718.htm>. Acesso em: 21 jan. 2007.

United States Diplomatic and Consular Staff in Tehran. Request for the Indication of Provisional Measures. Order. Demandante: EUA. Demandado: Irã. Den Haag. 15 dec. 1979. Disponível em: <http://www.icjcij.org/icjwww/icases/iusir/iusir_iorders/iusir_iorder_19791215.pdf>. Acesso em: 21 jan. 2007.

Cintra, A. C.; Grinover, A. P.; Dinamarco, C. R. (1999). Teoria Geral do Processo. 15. ed. São Paulo: Malheiros, 1999.

Convenção das Nações Unidas sobre Direito do Mar (UNCLOS), de 10 de dezembro de $1982 . \quad$ Disponível em: $<$ http://www.un.org/Depts/los/convention_agreements/texts/unclos/closindx.htm>. Acesso em: 21 jan. 2007.

Convenção de Montevidéu sobre Direitos e Deveres dos Estados, de 26 de dezembro de 1933. Disponível em: <http://www.yale.edu/lawweb/avalon/intdip/interam/intam03.htm>. Acesso em: 21 jan. 2007. 
Convenção de Viena sobre Direito dos Tratados, de $1^{\circ}$ de janeiro de 1969. Disponível em: <http://untreaty.un.org/ilc/texts/instruments/english/conventions/1_1_1969.pdf>. Acesso em: 21 jan. 2007.

Convenção para a Solução Pacífica dos Conflitos Internacionais, de 29 de julho de 1989. Disponível em: <http://www.pca-cpa.org/FRENCH/DB/DBFR/1899FRA.pdf>. Acesso em: 21 jan. 2007.

Convenção para a Solução Pacífica dos Conflitos Internacionais, de 18 de outubro de 1907. Disponível em: <http://www.pca-cpa.org/FRENCH/DB/DBFR/1907FRA.pdf>. Acesso em: 21 jan. 2007.

CoRTEn, O. The Controversies Over the Customary Prohibition on the Use of Force: A Methodological Debate. European Journal of International Law, v. 16, n. 5, p. 803-822, nov. 2005.

CPJI. Panevezys-Saldutiskis Railway. Demandante: Estônia. Demandado: Lituânia. Ser A/B, N. ${ }^{\circ} 76,1939$.

The Mavrommatis Palestine Concessions. Demandante: Grécia. Demandado: Reino Unido. CPJI, Ser. B., N. ${ }^{\circ}$ 3, 1924.

De la Guardia, E; Delpech, M. El Derecho de los Tratados y la Convención de Viena. Buenos Aires: La Ley Sociedad Anónima Editora e Impresora, 1970.

Declaração de Manila sobre a Solução Pacífica de Controvérsias Internacionais, de 15 de novembro de $1982 . \quad$ A/RES/37/10. Disponível em: $<$ http://daccessdds.un.org/doc/RESOLUTION/GEN/NR0/424/88/IMG/NR042488.pdf?Op enElement>. Acesso em: 21 jan. 2007.

Dinh, N. G.; Daillier, P.; Pellet, A. Direito Internacional Público. 2. ed. Lisboa: Fundação Calouste Gulbekian, 2003.

ECOSOC. Drafting Committee of the Preparatory Committee of the United Nations Conference on Trade and Employment. Draft General Agreement on Tariffs and Trade. E/PC/T/C.6/85. 15 feb. 1947.

. Protocol of Provisional Application of the General Agreement on Tariffs and Trade. E/PC/T/214.Add.2 Rev.1. s/d.

Second Session of the Preparatory Committee of the United Nations Conference on Trade and Employment. (Draft) General Agreement on Tariffs and Trade. E/PC/T/189. 30 aug. 1947.

Eichmann, E. P. Procedural Aspects of GATT Dispute Settlement: Moving Towards Legalism. International Tax \& Business Lawyer, v. 8, s/n, p. 38-77, 1990-1991.

Estatuto da Corte Internacional de Justiça. Disponível em: <http://www.icjcij.org/icjwww/ibasicdocuments/ibasictext/ibasicstatute.htm>. Acesso em: 21 jan. 2007.

FABRI, H. R. The WTO Appellate Body's Role: Should the Show Go on? In: OMC - 10 anos: Uma avaliação sobre o Órgão de Apelação [do] IDCID, maio 2005, São Paulo. 
FALK, R. A. International jurisdiction: Horizontal and vertical conceptions of legal order. Temple Law Quarterly, v. 32, s/n, p. 295/320, 1959.

. What Future for the UN Charter System of War Prevention?. The American Journal of International Law, v. 97, s/n, p.590-598, july 2003.

FEIS, H. The Geneva Proposals for an International Trade Charter. International Organization, v. 2, n. 1, p. 39-52, 1948.

Ferrajoli, L. A Soberania no Mundo Moderno. São Paulo: Martins Fontes, 2002.

Footer, M. E. The Role of Consensus in GATT/WTO Decision-making. Northwestern Journal of International Law \& Business, v. 17, s/n, p. 653-680, 1996-1997.

ForCESE, C. Shelter from the Storm: Rethinking Diplomatic Protection of Dual Nationals in Modern International Law. George Washington International Law Review, v. 37, s/n, p. 469-500, 2005.

GATT. Application of Article I:1 to Rebates on Internal Taxes. Ruling by the Chairman on 24 August 1948. Disponível em: <http://www.worldtradelaw.net/reports/gattpanels/>. Acesso em: 21 jan. 2007.

. Contractig Parties. BUDGET/1. Budget Estimates for 1950. 20 july 1949.

Secretary. 30 aug. 1951.

GATT/CP.6/10. Budget Estimates for 1952: Note by the Executive

L/1200. Establishment of a Council of the Contracting Parties. First

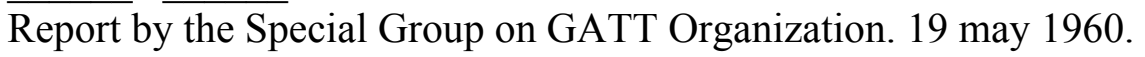

$\overline{\text { Group. }} 3 \overline{1 \text { may } 1960 .}$

L/1216. Proposals on GATT Organization. Second Report by the Special . L/1262/Add.2. Budget Estimates for the Financial Year 1961: Note by

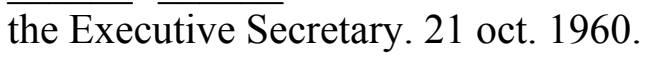

$\overline{\text { Executive Secretary. } 7 \text { july } 1961 .}$

L/1517. Budget Estimates for the Financial Year 1962: Note by the

L/1804. Budget Estimates for the Financial Year 1963: Note by the $\overline{\text { Executive Secretary. } 2 \text { july } 1962 .}$

. Council. C/M/1. Minutes of Meeting. 29 sept. 1960.

DS10/2. Thailand - Restrictions on Importation of and Internal Taxes on Cigarettes. Request for the Establishment of a Panel under Article XXIII:2 by the United States. 8 feb. 1990.

DS10/R. Thailand - Restrictions on Importation of and Internal Taxes on Cigarettes. Report of the Panel. Demandante: EUA. Demandado: Tailândia. 5 oct. 1990. 
DS21/R. United States - Restrictions on Imports of Tuna. Report of the Panel. Demandante: México. Demandado: EUA.

DS29/R. United States - Restrictions on Imports of Tuna. Report of the Panel. Demandante: CE. Demandado: EUA. 16 june 1994.

DS31/2. United States - Taxes on Automobiles. Request for the Establishment of a Panel under Article XXIII:2 by the European Economic Community. 12 mar. 1993.

. DS31/R. United States - Taxes on Automobiles. Report of the Panel. Demandante: CE. Demandado: EUA. 11 oct. 1994.

. General Council. PRESS/442. Press Release: WTO makes public all official

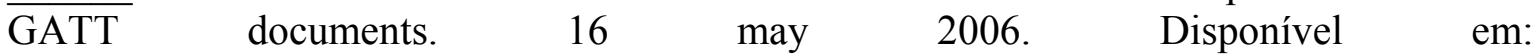
<http://www.wto.org/english/news_e/pres06_e/pr442_e.htm>. Acesso em: 04 dez. 2006.

L/105/Add.1. Budget Estimes for 1953: Addendum: Supplementary Note by the Executive Secretary. 25 aug. 1953.

. L/150. Budget Estimates for 1954: Note by the Executive Secretary. 17 aug. 1953.

Secretary. 19 july 1963.

. L/2246. Budget Estimates for the Financial Year 1965: Note by the Executive Secretary. 23 july 1964. 1954.

L/227. Budget Estimates for 1955: Note by the Executive Secretary. 22 sept.

. L/2456. Budget Estimates for the Financial Year 1966. 21 july 1965.

. L/2664. Budget Estimates for the Financial Year 1967. 5 july 1966.

. L/2803. Budget Estimates for the Financial Year 1968. 18 july 1967.

. L/3041. Budget Estimates for the Financial Year 1969. 18 july 1968.

. L/3222. Budget Estimates for the Financial Year 1970. 15 july 1969.

. L/3410. Budget Estimates for the Financial Year 1971. 10 july 1970.

. L/3540. Budget Estimates for the Financial Year 1972. s/d.

. L/3720. Budget Estimates for the Financial Year 1973. 7 july 1972.

L/3880. Budget Estimates for the Financial Year 1974. 26 july 1973.

L/392. Considerations Concerning Extended Use of Panels. Note by the Executive Secretary. 22 aug. 1955.

L/4040. Budget Estimates for the Financial Year 1975. 19 july 1974. 
L/4190. Budget Estimates for the Financial Year 1976. 10 july 1975.

L/423. Budget Estimates for 1956: Note by the Executive Secretary. 14 oct. 1955.

. L/4370. Budget Estimates for the Financial Year 1977. 7 july 1976.

. L/4511. Budget Estimates for the Financial Year 1978. 22 july 1977.

L/4690. Budget Estimates for the Financial Year 1979. 15 aug. 1978.

L/4820. Budget Estimates for the Financial Year 1980. 15 aug. 1979.

L/4931. Etats-Unis - Interdiction des Importations de Thon et de Produits du Thon em Provenance du Canada. Recours du Canada à l'article XXIII :2. 25 jan. 1980.

L/5020. Budget Estimates for the Financial Year 1981. 18 july 1980.

. L/506. Budget Estimates for 1957: Note by the Executive Secretary. 21 aug. 1956.

. L/5180. Budget Estimates for the Financial Year 1982. 30 july 1981.

L/5198. United States - Prohibition on Imports of Tuna and Tuna Products from Canada. Report of the Panel. Demandante: Canadá. Demandado: EUA. 22 dec. 1981.

. L/5350. Budget Estimates for the Financial Year 1983. 17 aug. 1982.

. L/5520. Budget Estimates for the Financial Year 1984. 6 july 1983.

. L/5700. Budget Estimates for the Financial Year 1985. 10 aug. 1984.

L/6132. Canada - Measures Affecting Exports of Unprocessed Herring and Salmon. Recourse to Article XXIII:2 by the United States. 20 feb. 1987.

L/6175. United States - Taxes on Petroleum and Certain Imported Substances.

Demandantes: Canadá e CE. Demandado: EUA. Geneve. 5 june 1987.

L/6220. Budget Estimates for the Financial Year 1988. 18 sept. 1987.

L/6268. Canada - Measures Affecting Exports of Unprocessed Herring and

Salmon. Report of the Panel. Demandante: EUA. Demandado: Canadá. 20 nov. 1987.

L/6390. Budget Estimates for the Financial Year 1989. 13 sept. 1988.

. L/654. Budget Estimates for 1958: Note by the Executive Secretary. 15 aug. 1957.

L/6550. Budget Estimates for the Financial Year 1990. 22 aug. 1989.

L/6850. Budget Estimates for the Financial Year 1991. 4 june 1991.

L/6900. Budget Estimates for the Financial Year 1992. 30 sept. 1991.

L/7070. Budget Estimates for the Financial Year 1993. 18 sept. 1992. 
L/7300. Budget Estimates for the Financial Year 1994. 24 sept. 1993.

L/845.Budget Estimates for 1959: Note by the Executive Secretary. 29 aug. 1958.

1973.

. Ministerial Meeting. MIN(73)SR. Summary Record of the Meeting. 28 sept.

. Multilateral Trade Negotiations. Group Safeguards. MTN/SG/W/8. Dispute Settlement in International Economic Agreements. Factual Study by the Secretariat. 6 apr. 1976.

Parties contractantes. GATT/CP.2/WP.1/2. Accord General sur les Tarifs Douaniers et le Commerce. Group de Travail No. I (Finances). Previsions Budgetaires des Parties Contractantes pour le période du 16 août au 31 décembre 1948. 20 aug. 1948.

SR. 7/7. Summary Record of the Seventh Meeting. 18 oct. 1952.

. The Phrase “Charges of Any Kind” in Article I:1 in Relation to Consular

Taxes. Ruling by the Chairman on 24 August 1948.Disponível em: $<$ http://www.worldtradelaw.net/reports/gattpanels/>. Acesso em: 21 jan. 2007.

W.7/20. Panel on Complaints. 14 oct. 1952.

Germer, P. Interpretation of Plurilingual Treaties: A Study of Article 33 of the Vienna Convention on the Law of Treaties. Harvard International Law Journal, v. 11, s/n,p. 400-427, 1970.

GoldsteIn, J. et al. Introduction: Legalization and World Politics. International Organization, v. 54, n. 3, p. 385-399, Summer 2000.

GRZYBOwSKI, K. Interpretation of Decisions of International Tribunals. The American Journal of International Law, v. 35, s/n, p. 482-495, 1941.

HAMmarskJölD, A. The Place of the Permanent Court of International Justice within the System of the League of Nations. International Journal of Ethics, v. 34, n. 4, p. 146-156, jan. 1924.

HARris, K. M. The Post-Tokyo Round GATT Role in International Trade Dispute Settlement. International Tax \& Business Lawyer, v. 1, s/n, p. 142-176, 1983.

Hart, H. L. A. The Concept of Law. 2. ed. Oxford: Oxford University Press, 1997.

Helfer, L. R.; Slaughter, A.-M. Toward a Theory of Effective Supranational Adjudication. Yale Law Journal, v. 107, s/n, p. 273-391, 1997-1998.

HEXNER, E. P. Interpretation by Public International Organizations of their Basic Instruments. The American Journal of International Law, v. 53, s/n, p. 341-370, 1959.

HogG, J. F. International Court: Rules of Treaty Interpretation II. Minnesota Law Review, v. 44, s/n, p. 5-73, 1959-1960. 
HogG, J. F. International Court: Rules of Treaty Interpretation. Minnesota Law Review, v. 43, s/n, p. 369- 441, 1958-1959.

Howse, R. From Politics to Technocracy - and Back Again: The Fate of the Multilateral Trading Regime. The American Journal of International Law, v. 96, n. 1, p. 94/117, 2002.

Hudec, R. E. A Statistical Profile of GATT Dispute Settlement Cases: 1948-1989. Minnesota Journal of Global Trade, v. 2, p. 1/100, 1993.

. Book Review: The GATT/WTO Dispute Settlement System: International Law, International Organizations and Dispute Settlement. The American Journal of International Law, v. 91, n. 4, p. 750-752, oct. 1997.

Dispute Settlement. In: SchotT, Jeffrey J. (ed.). Completing the Uruguay Round: a Results-Oriented Approach to the GATT Trade Negotiations. Washington: Institute for International Economics, p. 180-204, 1990.

. GATT Dispute Settlement after the Tokyo Round: An Unfinished Business. Cornell International Law Journal, v. 13, n. 2, p. 145-203, summer 1980. Publishers, 1975.

The GATT Legal System and World Trade Diplomacy. New York: Praeger

The Role of the GATT Secretariat in the Evolution of the WTO Dispute Settlement Procedure. In: Bhagwati, J.; Hirsch, M. (eds.). The Uruguay Round and Beyond: Essays in Honour of Arthur Dunkel. s/l: Springer-Verlag, p. 101-120, 1998. Disponível em: <http://www.worldtradelaw.net/articles.htm>. Acesso em: 21 jan. 2007.

Hudson, M. O. The Succesion of the International Court of Justice to the Permanent Court of International Justice. The American Journal of International Law, v. 51, n. 3, p. 569573, july 1957.

HydE, C. C. The Interpretation of Treaties by the Permanent Court of International Justice. The American Journal of International Law, v. 24, s/n, p. 1-19, 1930.

ICITO. ICITO/1/W.4. Budget estimates for 1950: Note by the Executive Secretary. 30 july 1949. Disponível em: <gatt.stanford.edu>. Acesso em: 13 nov. 2006.

. ICITO/EC.1/3. Executive Committee. Draft Rules of Procedure. 19 mar. 1948.

ICITO/EC.2/5. Report by the Executive Secretary of the ICITO on the Work of the Secretariat. 13 july 1948. Disponível em: <gatt.stanford.edu>. Acesso em: 13 nov. 2006.

ICSID. Caso N. ${ }^{\circ}$ ARB/02/18. Demandante: Tokios Tokelès. Demandado: Ucrânia. Washington, D.C. apr. 2004. Disponível em $<$ http://www.worldbank.org/icsid/>. Acesso em: 29 jan. 2006.

JACKSON, J. H. Book Review: Law and Its Limitations in the GATT Multilateral Trade System. The American Journal of International Law, v. 82, n. 3, p. 653-654, july 1988. 
GATT and the Future of International Trade Institutions. The Brooklyn Journal of International Law, v. 18, s/n, p. 11-29, 1992.

. GATT as an Instrument for the Settlement of Trade Disputes. American Society of International Law Proceedings of the Annual Meeting, v. 61, p. 144-154, 1967.

Reflections on Restructuring the GATT. In: ScHOTT, Jeffrey J. (ed.). Completing the Uruguay Round: a Results-Oriented Approach to the GATT Trade Negotiations. Washington: Institute for International Economics, p. 205-224, 1990.

. The Changing Fundamentals of International Law and Ten Years of the WTO (Part I: The State of International Economic Law - 2005). Journal of International Economic Law, v. 8, n.1, p. 3-15, 2005.

The World Trading System: Law and Policy of International Economic Relations. 2. ed. Cambridge: The MIT Press, 1997.

. The WTO Dispute Settlement Understanding: Some Misunderstandings on the Nature of Legal Obligation. The American Journal of International Law, v. 91, n. 1, p. 60-64, 1997.

JACOBS, F. G. Varieties of Approach to Treaty Interpretation: With Special Reference to the Draft Convention on the Law of Treaties before the Vienna Diplomatic Conference. International and Comparative Law Quarterly, n. 18, p. 318-346, 1969.

KAHLER, M. Conclusion: The Causes of Legalization. International Organization, v. 54, n. 3, p. 661-683, 2000.

Kelsen, H. Teoria Geral do Direito e do Estado. 3. ed. São Paulo: Martins Fontes, 2000. Teoria Pura do Direito. 6. ed. São Paulo: Martins Fontes, 1998.

The Law of the United Nations: A Critical Analysis of its Fundamental Problems. New York: Frederick A. Praeger Inc., 1951.

Keohane, R. O.; Moravcsik, A.; Slaughter, A.-M. Legalized Dispute Resolution: Interstate and Transnational. International Organization, v. 54, n. 3, p. 457-488, 2000.

KunER, C. B. The Interpretation of Multilingual Treaties: Comparison of Texts versus the Presumption of Similar Meaning. International and Comparative Law Quarterly, v. 40, n. 4, p. 953-964, oct. 1991.

Kuruvila, P. E. (1997). Developing Countries and the GATT/WTO Dispute Settlement Mechanism. Journal of World Trade, v. 31, n. 6, p. 189-190, 1997.

KUYPER, P. J. The law of GATT as a special field of International law. The Netherlands Yearbook of International Law, v. 25, p. 227/257, 1994.

LAFER, C. A OMC e a Regulamentação do Comércio Internacional: uma visão brasileira. Porto Alegre: Livraria do Advogado, 1998. 
. O sistema de solução de controvérsias da Organização Mundial do Comércio. In: CAsella, Paulo B.; Mercadante, Araminta de A. (coord.). Guerra Comercial ou integração Mundial pelo Comércio? A OMC e o Brasil. 1.a ed. São Paulo: LTR, p. 729$755,1998$.

LAMY, S. L. (2001). Contemporary mainstream approaches: neo-realism and neoliberalism. In: BAylis, J.; SMith, S. (orgs). The Globalization of World Politics: An introduction to international relations. 2. ed. Oxford: Oxford University Press, p. 182$199,2001$.

LAUterpacht, H. Lês Travaux Préparatoires et l'Interpretation des Traités. Collected Courses of The Hague Academy of International Law, v. 48, n. II, p. 708-817, 1934.

Liacouras, P. J. The International Court of Justice and Development of Useful 'Rules of Interpretation' in the Process of Treaty Interpretation. Proceedings of the Annual Meeting of the American Society of International Law, v. 59, p. 161-168, 1965.

LIANG, M. Evolution of the WTO Decision Making Process. Singapore Year Book of International Law and Contributors, v. 9, s/n, p. 125-132, 2005.

LiMA, J. C. L. A. S. (1927). Da Sociedade das Nações. Lisboa: Rodriques, 1927.

LONG, O. Law and its Limitations in the GATT Multilateral Trade System. London: Graham \& Trotman/Martinus Nijhoff, 1987.

MAKI, P. C. Interpreting GATT using the Vienna Convention on the Law of Treaties: A Method to Increase the Legitimacy of the Dispute Settlement System. Minnesota Journal of Global Trade, v. 9, s/n, p.343-360, 2000.

MARCEAU, G. A call for coherence in international law: praises for the prohibition against "clinical isolation" in WTO dispute settlement. Journal of World Trade: law, economics, public policy, v.33, n.5, p. 87-152, 1999.

. WTO Dispute Settlement and Human Rights. European Journal International

Law, v. 13 n. 4, Oxford, 2002, p. 753/815. Disponível em $<$ http://www.ejil.org/journal/Vol13/No4/art1.html>. Acesso em: 17 set. 2005.

MatsushitA, M. Governance of International Trade under the WTO Agreements Relationships between WTO Agreements and Other Agreements. Journal of World Trade, v. 38, n. 2, p. 185-210, 2004.

Mavroidis, P. Amicus Curiae Briefs Before the WTO: Much Ado About Nothing. Jean Monnet Working Paper 2/01. Disponível em: $<$ http://www. jeanmonnetprogram.org/papers/01/010201.rtf>. Acesso em: $1^{\circ}$ abr. 2004.

; PALMeter, D. The WTO Legal System: Sources of Law. The American Journal of International Law, v. 92, n. 3, p. 398-413, 1998.

McMahon, J. F. The Court of European Communities Judicial Interpretation and International Organization. British Yearbook of International Law, v. 37, p. 320-350, 1961. 
MCRAE, D. M. The contribution of international trade law to the development of international law. Collected Courses of The Hague Academy of International Law, n. 260, p. 99/238, 1996.

Mitchell, J. W. The Idea of the General Agreement on Tariffs and Trade and of the Organization for Trade Cooperation. Texas Law Review, v. 34, s/n, p. 926-934, 1995 1956.

Morgenthau, H. J. A Política entre as Nações: a luta pelo poder e pela paz. Brasília: Editora Universidade de Brasília: Imprensa Oficial do Estado de São Paulo: Instituto de Pesquisa de Relações Internacionais, 2003.

MoRss, J. R. Sources of Doubt, Sources of Duty: HLA Hart on International Law. Deakin Law Review, v. 10, s/n, p. 698-707, 2005.

Mosoti, V. Does Africa Need the WTO Dispute Settlement System?. In: Making the WTO Dispute Settlement System Work for Developing and Least Developed Countries [do] ICTSD, 7 fév. 2003, Geneve.

OAKESHOTT, M. On history and other essays. Indianopolis: Liberty Fund, s/a., p. $129 / 178$.

OMC. [DSB]. WT/DS135/12. European Communities - Measures Affecting Asbestos and Asbestos Containing Products. Appellate Body Report and Panel Report. Action by the Dispute Settlement Body. Demandante: Canadá. Demandado: CE. Geneve. 11 apr. 2001.

WT/DS135/AB/R. European Communities - Measures Affecting Asbestos and Asbestos Containing Products. Report of the Appellate Body. Apelantes: Canadá e CE. Apelados: Canadá e CE. Geneve. 12 mar. 2001.

. WT/DS135/R. European Communities - Measures Affecting Asbestos and Asbestos Containing Products. Report of the Panel. Demandante: Canadá. Demandado: CE. Geneve. 18 sept. 2000.

. WT/DS138/R. United States - Imposition of Countervailing Duties on Certain Hot-Rolled Lead and Bismuth Carbon Steel Products Originating in the United Kingdom. Report of the Panel. Demandante: CE. Demandado: EUA. 23 dec. 1999.

. WT/DS18/AB/R. Australia - Measures Affecting Importation of Salmon. Report of the Appellate Body. Apelante: Austrália e Canadá. Apelado: Austrália e Canadá. Geneve. 20 oct. 1998.

WT/DS18/R. Australia - Measures Affecting Importation of Salmon. Report of the Panel. Demandante: Canadá. Demandado: Austrália. Geneve. 12 june 1998.

WT/DS2/9. United States - Standards for Reformulated and Conventional Gasoline. Appellate Body Report and Panel Report. Action by the Dispute Settlement Body.Demandantes: Brasil e Venezuela. Demandado: EUA. Geneve. 20 may 1996. 
WT/DS2/AB/R. United States - Standards for Reformulated and Conventional Gasoline. Report of the Appellate Body. Apelante: EUA. Apelados: Brasil e Venezuela. Geneve. 29 apr. 1996.

WT/DS2/R. United States - Standards for Reformulated and Conventional Gasoline. Report of the Panel. Demandantes: Brasil e Venezuela. Demandado: EUA. Geneve. 29 jan. 1996.

. WT/DS246/10. European Communities - Conditions for the Granting of Tariff Preferences to Developing Countries. Appellate Body Report and Panel Report. Action by the Dispute Settlement Body. Demandante: Índia. Demandado: CE. Geneve. 23 apr. 2004.

. WT/DS246/AB/R. European Communities - Conditions for the Granting of Tariff Preferences to Developing Countries. Report of the Appellate Body. Apelante: CE. Apelado: Índia. Geneve. 7 apr. 2004.

. WT/DS246/R. European Communities - Conditions for the Granting of Tariff Preferences to Developing Countries. Report of the Panel. Demandante: Índia. Demandado: CE. Geneve. 1 dec. 2003.

. WT/DS26/AB/R. EC - Measures Concerning Meat and Meat Products (Hormones). Report of the Appellate Body. Apelantes: Canadá, CE e EUA. Apelados: Canadá, CE e EUA. Geneve. 16 jan. 1998.

. WT/DS26/R/USA. EC - Measures Concerning Meat and Meat Products (Hormones). Report of the Panel. Demandante: EUA. Demandado: CE. Geneve. 18 aug. 1997.

WT/DS302/R. Dominican Republic - Measures Affecting the Importation and Internal Sale of Cigarretes. Report of the Panel. Demandante: Honduras. Demandado: República Dominicana. Geneve. 26 nov. 2004.

. WT/DS48/R/CAN. EC - Measures Concerning Meat and Meat Products (Hormones). Report of the Panel. Demandante: Canadá. Demandado: CE. Geneve. 18 aug. 1997.

WT/DS58/14. United States - Import Prohibition of Certain Shrimp and

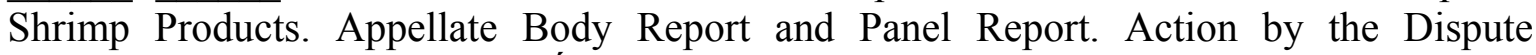
Settlement Body. Demandante: Índia, Malásia, Paquistão e Tailândia. Demandado: EUA. Geneve. 9 apr. 1999.

. WT/DS58/AB/R. United States - Import Prohibition of Certain Shrimp and Shrimp Products. Report of the Appellate Body. Apelante: EUA. Apelados: Índia, Malásia, Paquistão e Tailândia. Geneve. 12 oct. 1998.

. WT/DS58/R. United States - Import Prohibition of Certain Shrimp and

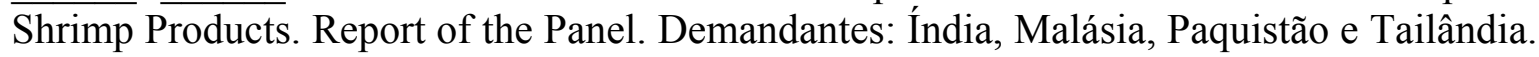
Demandado: EUA. Geneve. 15 may 1998. 
TN/DS/W/28. Negotiations on Improvements and Clarifications of the $\overline{\text { Dispute }}$ Settlement Understanding on Improving Flexibility and Member Control in WTO Dispute Settlement. Contribution by Chile and the United States. 23 dec. 23 dec. 2002.

. TN/DS/W/41. Special Session. Contribution of Canada to the Improvement of the WTO Dispute Settlement Understanding. Communication from Canada. 24 jan. 2003.

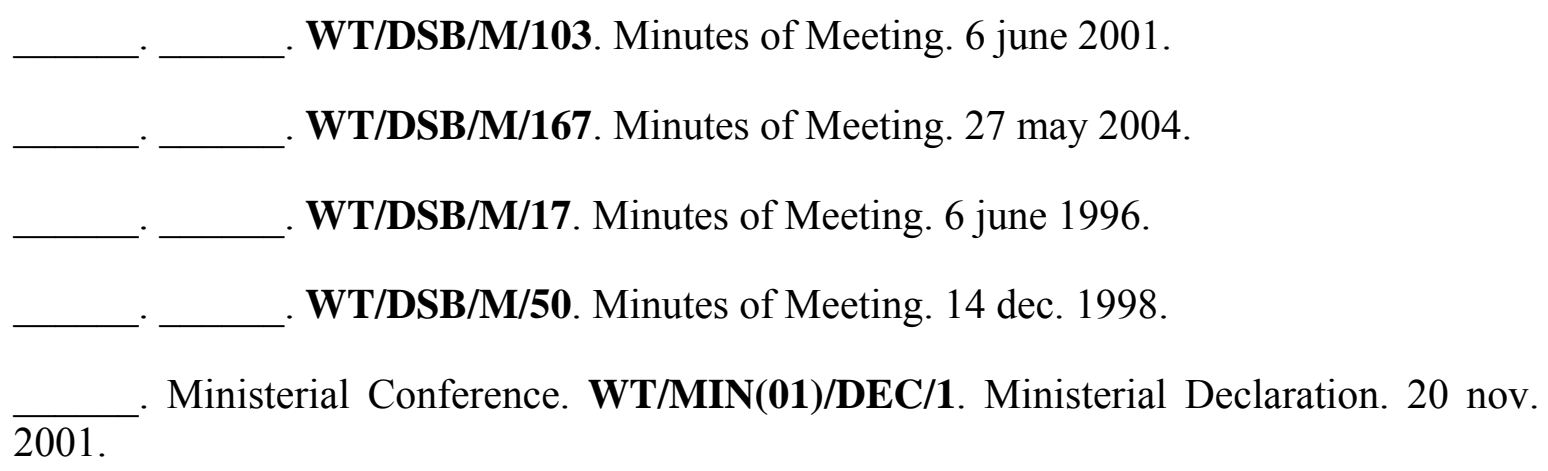

. Trade Negotiations Committee. TN/C/1. Statement by the Chairman of the General Council. 2 feb. 2002.

. Understanding the WTO. The Organization. The Secretariat. Secretariat Chart. Disponível em: <http://www.wto.org/english/thewto_e/whatis_e/tif_e/org4_e.htm>. Acesso em: 21 jan. 2007.

. Understanding the WTO. The Organization. WTO Organization Chart. Disponível em: <http://www.wto.org/english/thewto_e/whatis_e/tif_e/org2_e.htm>. Acesso em: 21 jan. 2007.

WT/DS135/3. European Communities - Measures Affecting Asbestos and Asbestos Containing Products. Request for the Establishment of a Panel by Canada. 9 oct. 1998.

WT/DS2/2. United States - Standards for Reformulated and Conventional Gasoline. Request for Establishment of Panel by Venezuela under Article XXIII:2 of the GATT 1994 and Article 6 of the Understanding on Rules and Procedures Governing the Settlement of Disputes (DSU). 27 mar. 1995.

WT/DS246/4. European Communities - Conditions for the Granting of Tariff Preferences to Developing Countries. Request for the Establishment of a Panel by India. 9 dec. 2002.

. WT/DS58/6. United States - Import Prohibition of Certain Shrimp and Shrimp Products. Request for the Establishment of a Panel by Malaysia and Thailand. 10 jan. 1997.

WT/DS58/7. United States - Import Prohibition of Certain Shrimp and Shrimp Products. Request for the Establishment of a Panel by Pakistan. 7 feb. 1997.

. WT/DS58/8. United States - Import Prohibition of Certain Shrimp and Shrimp Products. Request for the Establishment of a Panel by India. 4 mar. 1997. 
WT/L/160/Rev.1. Procedures for the Circulation and Derestriction of WTO Documents. Decision adopted by the General Council on 18 July 1996. 26 july 1996.

ONU. A/46/33: Official Records: Forty-Sixty Session, Supplement n. ${ }^{\circ}$ 33: Handbook on the Peaceful Settlement of Dispute Between States", 1991. Disponível em: $<$ unbisnet.un.org>. Acesso em: 25 jan. 2006.

OPPENHEIM, L. F. L. The league of nations and its problems: three lectures. London: Longmans, Green and Co., 1919.

Pacto Briand-Kellog, de 27 de agosto de 1928. Disponível em: $<$ http://www.yale.edu/lawweb/avalon/kbpact/kbpact.htm>. Acesso em: 21 jan. 2007.

Pacto da Liga das Nações (LDN), de 28 de junho de 1919. Disponível em: $<$ http://www.yale.edu/lawweb/avalon/leagcov.htm>. Acesso em: 21 jan. 2007.

PALMETER, D. The WTO as a Legal System. Fordham International Law Journal, v. 24, Fordham, p. 444-480, 2002.

Pauwelyn, J. Conflict of Norms in Public International Law: How WTO Law Relates to other Rules of International Law. Cambridge: Cambridge University Press, 2005.

. The Nature of WTO Obligations. Jean Monnet Working Paper 1/02. Disponível em: <http:/www.jeanmonnetprogram.org/papers/02/020101.html>. Acesso em: 17 set. 2005.

The Role of Public International Law in the WTO: How far can we go?. The American Journal of International Law, v. 95, n. 3, Washington, p. 535-578, 2001.

Perez, O. Ecological Sensitivity and Global Legal Pluralism: Rethinking the Trade and Environment Conflict. Portland: Hart Publishing, 2004.

Petersmann, E.-U. From Diplomacy to Law: The Juridicization of International Trade Relations. Northwestern Journal of International Law \& Business, v. 17, s/n, p. 775848, winter1996 -spring 1997.

The GATT/WTO Dispute Settlement system: International Law, International Organizations, and Dispute Settlement. 1. ed. 2. reimp. London: Kluwer Law International, 1998.

Phillimore, F. (1922). The Permanent Court of International Justice. Journal of the British Institute of International Affairs, v. 1, n. 4, p. 113-123, july 1922.

Pierson, C. Preemptive Self-Defense in an Age of Weapons of Mass Destruction: Operation Iraqi Freedom. Denver Journal of International Law and Policy, v. 33, s/n, p. 150-178, winter 2004.

Protocolo de Brasília para a Solução de Controvérsias, de 17 de dezembro de 1991. Disponível em: <http://www.mercosur.int> . Acesso em: 21 jan. 2007.

Protocolo de Olivos para a Solução de Controvérsias no Mercosul, de 18 de fevereiro de 2002. Disponível em: <http://www.mercosur.int>. Acesso em: 21 jan. 2007. 
RAngel, V. M. Direito e Relações Internacionais. 6. ed. São Paulo: Editora Revista dos Tribunais, 2000.

REHBERG, J. WTO/GATT Research. New York University. 29 sept. 2003. Disponível em: $<$ http://www.llrx.com/features/wto2.htm>. Acesso em: 18 jan. 2007.

REZEK, J. F. Direito dos Tratados. Rio de Janeiro: Forense, 1984.

RIS, M. Treaty Interpreation and ICJ Recourse to Travaux Préparatoires: Towards a Proposed Amendment of Articles 31 and 32 of the Vienna Convention on the Law of Treaties. Boston College International \& Comparative Law Review, v. XIV, n. 1, p. 111-136, 1991.

RomÁn, C. A. La solución de controvérsias internacionales y sus mecanismos. Revista de la Facultad de Derecho Universidad Complutense, Curso 1994-1995, p. 93-113, 1996.

Romano, C. P. R. The Proliferation of International Judicial Bodies: The Pieces of the Puzzle. New York University Journal of International Law and Politics, v. 31, s/n, p. 709-751, 1998-1999.

SAnchez, M. R. Demandas por um Novo Arcabouço Sociojurídico na Organização Mundial do Comércio e o Caso do Brasil. Tese de Doutorado defendida junto ao Departamento de Filosofia e Teoria Geral do Direito da Faculdade de Direito da USP. 30 abr. 2004. 453 p.

SAPIENZA, R. Les Déclarations Interpretatives Unilatérales et l'Interpretation dês Traités. Revue Générale de Droit International Public, v. 103, n. 3, p. 601-629, 1999.

SAPIRO, M. Iraq: The Shifting Sands of Preemptive Self-Defense. The American Journal of International Law, v. 97, s. n., p. 599-607, July 2003.

Scelle, G. Manuel de Droit International Public. Paris : Editions DommatMontchrestien, 1948.

SCHERMES, H. G. Les bases juridiques de l'action des organizations internationales. In : DuPUY, René-Jean (coord.). Manuel sur Les Organisations Internationales, 2. ed. London: Kluwer Law International, p. 401/411, 1998.

Schwarzenberger, G. Myths and Realities of Treaty Interpretation: Articles 27-29 of the Vienna Draft Convention on the Law of Treaties. Virginia Journal of International Law, v. 9, p. 1-19, 1968-1969.

Scotт, J. B. A Permanent Court of International Justice. The American Journal of International Law, v. 15, n. 1, p. 52-55, jan. 1921.

SHAW, M. International Law. 4. ed. Cambridge: Cambridge University Press, 1997.

SHELL, R. G. Trade Legalism and International Relations Theory: An Analysis of the World Trade Organization. Duke Law Journal, v. 44, p. 829-927, mar. 1995.

Silva, E. C. G. Mercosul-União Européia-ALCA e o Direito Comunitário: Uma análise do papel do sistema de solução de controvérsias. MEnEzes, W. (org.). Estudos de Direito 
Internacional: Anais do $\mathbf{2}^{\mathbf{0}}$ Congresso Brasileiro de Direito Internacional. v. 1. Curitiba: Juruá, pp. 281-283, 2004.

Silva, G. E. N. Conferência de Viena sobre o Direito dos Tratados. Brasília: Ministério das Relações Exteriores, 1971.

Sinclair, I. The Vienna Convention on the Law of Treaties. 2. ed. Manchester: Manchester University Press, 1984.

Smith, J. M. The Politics of Dispute Settlement Design: Explaining Legalism in Regional Trade Pacts. International Organization, v. 54, n.1, p. 137/180, 2000.

SoAres, G. F. S. Curso de Direito Internacional Público. v. 1. São Paulo: Editora Atlas, 2002.

. Uma revisão em profundidade em 1996: As Instituições do MERCOSUL e as soluções de litígios no seu âmbito - Sugestões. In: BAPTISTA, L. O. et al (orgs.) MERCOSUL: das negociações à implantação. 2. ed. São Paulo: Editora LTR, p. 31-68, 1998.

Steger, D. P. Afterword: the "Trade and..." Conundrum - A Commentary. The American Journal of International Law, v. 96, n. 1, p. 135-145, 2002.

- The WTO in Public International Law: Jurisdiction, Interpretation and Accomodation. In: OMC - 10 anos: Uma avaliação sobre o Órgão de Apelação [do] IDCID, maio 2005, São Paulo.

Sweet, A. S. Judicialization and the Construction of Governance. Comparative Political Studies, v. 32, n. 2, p. 147-184, apr. 1989.

The New GATT: Dispute Resolution and the Judicialization Regime. In: VOLCANSEK, M. (ed.). Law Above Nations: Supranational Courts and the Legalization of Politics. Gainesville: University of Florida Press, p. 118-141, 1997.

The American Journal of InTERnational LaW. Resolution Concerning the Establishment of the Permanent Court of International Justice Passed Unanimously by the Assembly of the League of Nations. v. 17, n. 2, p. 55, Apr. 1923.

. Signatures and Ratifications of the Protocolo of Signature of the Permanent Court of International Justice. v. 20, n. 2, p. 74-75, apr. 1926.

Thorstensen, V. O Papel do Órgão de Apelação: visão das comunidades diplomática e acadêmica. In: OMC - 10 anos: Uma avaliação sobre o Órgão de Apelação [do] IDCID, maio 2005, São Paulo.

OMC: As Regras do Comércio Internacional e a Nova Rodada de Negociações Multilaterais. 2. ed. São Paulo: Aduaneiras, 2001.

Trachtman, J. P. The Domain of WTO Dispute Resolution. Harvard International Law Journal, v. 40, n. 2, p. 333-377, 1999. 
Trindade, A. A. C. The Consolidation of the Procedural Capacity of Individuals in the Evolution of the International Protection of Human Rights: Present State and Perspectives at the Turn of the Century. Columbia Human Rights Law Review, v. 30, p. 1-27, Fall 1998.

UNCTAD. Dispute Settlement: Investor-State. UNCTAD/ITE/IIT/30. Geneve: United Nations, 2003. UNCTAD Series on issues in international investment agreements.

UNCTE. E/CONF.2/67. Resolution Establishing the Interim Commission. Note by the Executive Secretary. 16 mar. 1948.

USITC. Review of the Effectiveness of Trade Dispute Settlement under the GATT and the Tokyo Round Agreements: Report to the Committee on Finance, US Senate, on Investigation No. 332-212 Under Section 332(g) of the Tariff Act of 1930: USITC Publication 1793. Washington, DC: USITC, 1985.

VAN DER BORGHT, K. The review of the WTO understanding on dispute settlement: some reflections on the current debate. The American University International Law Review, v. 14, n. 4, Washington, p. 1223-1243, 1998.

Ventura, D. As Assimetrias entre o Mercosul e a União Européia: Os desafios de uma associação inter-regional. Barueri: Manole, 2003.

Vermulst, E.; DrIESSEN, B. An overview of the WTO dispute settlement system and its relationship with the Uruguay round. Journal of World Trade: law, economics, public policy, v. 29, n. 2, p. 131-161, 1995.

Von Mehren, A. T. Adjudicatory Jurisdiction: General Theory Compared and Evaluated. Boston University Law Review, v. 63, s/n, p. 279-340, 1983.

WeILER, J. H. H. The Rule of Lawyers and the Ethos of Diplomats: Reflections on the Internal and External Legitimacy of WTO Dispute Settlement. Harvard Jean Monnet Working Paper 9/00. Disponível em: <http://www.jeanmonnet program.org/bnpapers/ 00/000901.html>. Acesso em: 17 set. 2005.

White, G. Treaty interpretation: The Vienna Convention 'Code' as Applied by the World Trade Organization Judiciary. Australia Yearbook of International Law, v. 20, p. 319339, 1999.

WiLson, R. R. Toward a World Conference on Trade and Employment. The American Journal of International Law, v. 41, n. 1, p. 127-131, 1947.

\section{PÁginas ELETRônicas}

CIJ. Disponível em: <http://www.icj-cij.org>. Acesso em: 21 jan. 2007.

Max Planck Institute for Comparative Public LaW and International Law. Wourld Court Digest. Disponível em: 
$<$ http://www.mpil.de/ww/en/pub/research/details/publications/institute/wcd.cfm>. Acesso em: 21 jan. 2007.

MERCOSUL. Disponível em: <http://www.mercosur.int>. Acesso em: 21 jan. 2007.

OMC. Documentos do GATT-1947. Disponível em: $<$ http://www.wto.org/english/docs_e/gattdocs_e.htm>. Acesso em: 21 de janeiro de 2007.

. Lista das disputas apresentadas em ordem cronológica. Disponível em:

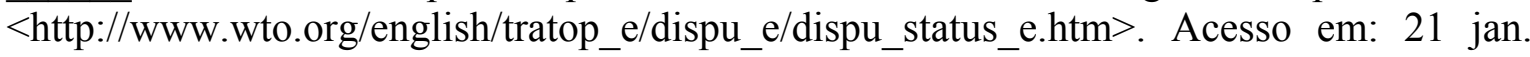
2007.

. Relatórios das disputas apresentadas sob a égide do GATT-1947 que foram adotados. Disponível em: <http://www.wto.org/english/tratop_e/dispu_e/gt47ds_e.htm>. Acesso em: 21 de janeiro de 2007.

REINHARDT, E. Base de dados relativos às disputas apresentadas sob a égide do GATT1947. Disponível em: <http://userwww.service.emory.edu/ erein/data/\#GATT>. Acesso em: 21 jan. 2007.

TPA. Disponível em: <http://www.pca-cpa.org/>. Acesso em: 21 jan. 2007.

UnIVERSIDADE DE STANFORD. Documentos do GATT-1947. Disponível em: < gatt.stanford.edu>. Acesso em: 21 jan. 2007.

UNIVERSIDADE DE YALE. Projeto Avalon. Disponível em: $<$ http://www.yale.edu/lawweb/avalon/avalon.htm>. Acesso em: 21 jan. 2007.

WORLD COURTS. Base de dados sobre Cortes Internacionais. Disponível em: $<$ http://www.worldcourts.com>. Acesso em: 21 jan. 2007.

World Trade Law Net. Artigos sobre comércio internacional. Disponível em: $<$ http://www.worldtradelaw.net/articles.htm>. Acesso em: 21 de janeiro de 2007. 


\section{APÊNDICE A - ORGANOGRAMA DO GATT-1947 (1948-1994)}

A seguir, são apresentados os organogramas relativos à estrutura organizacional que conduziu os trabalhos no âmbito do GATT-1947 no período entre 1948 (ano em que o GATT-1947 entra em vigência) e 1994 (ano anterior à entrada em vigor da OMC).

Em razão da dificuldade de acesso a documentos comprovantes da criação de órgãos no âmbito do GATT-1947, supõe-se que a estrutura deste encontra-se refletida na do próprio Secretariado. Ressalta-se, contudo, que esta informação pode ser complementada ou corrigida por documentos que não estavam disponíveis até a finalização desta pesquisa. A linha abaixo do Conselho representa a possibilidade de existência de outros órgãos.

Os organogramas foram elaborados com base nos relatórios financeiros de prestação de contas e requisição de recursos às Partes Contratantes e na minuta da primeira reunião do Conselho. Os documentos utilizados para elaboração dos organogramas são os seguintes $^{173}$ :

\begin{tabular}{clll}
\hline Ano & \multicolumn{1}{c}{ Documento } & Ano & \multicolumn{1}{c}{ Documento } \\
\hline 1948 & GATT (GATT/CP.2/WP.1/2) & 1963 & GATT (L/1804) \\
1950 & $\begin{array}{l}\text { ICITO (ICITO/1/W.4); GATT } \\
(\text { BUDGET/1) }\end{array}$ & 1964 & GATT (L/2033) \\
1952 & GATT (GATT/CP.6/10) & 1965 & GATT (L/2246) \\
1954 & GATT (L/105) & 1966 & GATT (L/2456) \\
1955 & GATT (L/227) & 1967 & GATT (L/2664) \\
1956 & GATT (L/423) & 1968 & GATT (L/2803) \\
1957 & GATT (L/506) & 1969 & GATT (L/3041)
\end{tabular}

${ }^{173}$ Todos os documentos indicados encontram-se disponíveis em: <gatt.stanford.edu>. Acesso em: out. 2006. 


\begin{tabular}{clcl}
\hline Ano & \multicolumn{1}{c}{ Documento } & Ano & \multicolumn{1}{c}{ Documento } \\
\hline 1958 & GATT (L/654) & 1970 & GATT (L/3222) \\
1959 & GATT (L/845) & 1981 & GATT (L/5020) \\
1961 & GATT (L/1262/Add.2); GATT & 1982 & GATT (L/5180) \\
1962 & GATT (L/1517) & 1983 & GATT (L/5350) \\
1971 & GATT (L/3410) & 1984 & GATT (L/5520) \\
1972 & GATT (L/3540) & 1985 & GATT (L/5700) \\
1973 & GATT (L/3720) & 1988 & GATT (L/6220) \\
1974 & GATT (L/3880) & 1989 & GATT (L/6390) \\
1975 & GATT (L/4040) & 1990 & GATT (L/6550) \\
1976 & GATT (L/4190) & 1991 & GATT (L/6850) \\
1977 & GATT (L/4370) & 1992 & GATT (L/6900) \\
1978 & GATT (L/4511) & 1993 & GATT (L/7070) \\
\hline 1980 & GATT (L/4690) & & \\
\hline
\end{tabular}




\section{2}
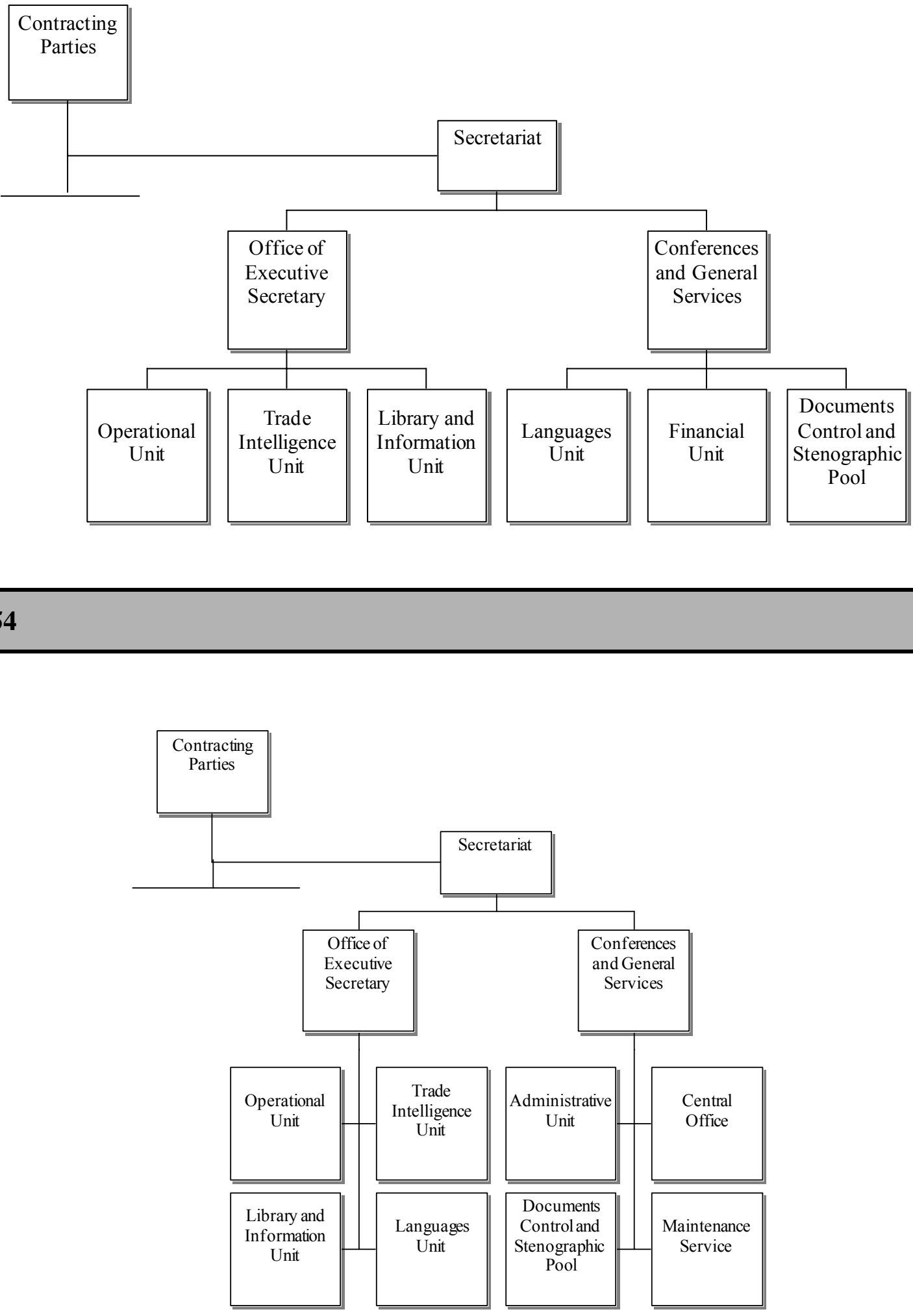


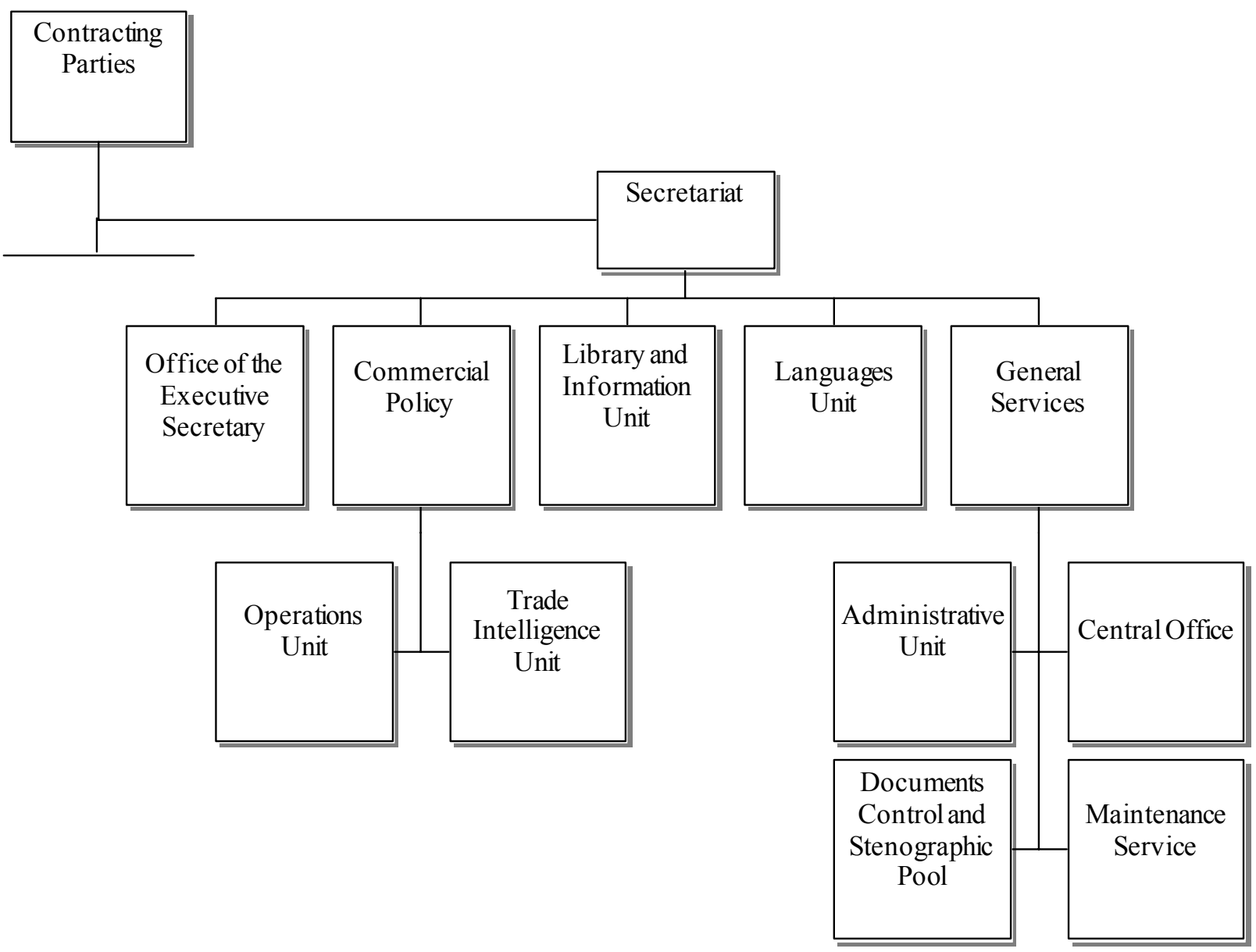




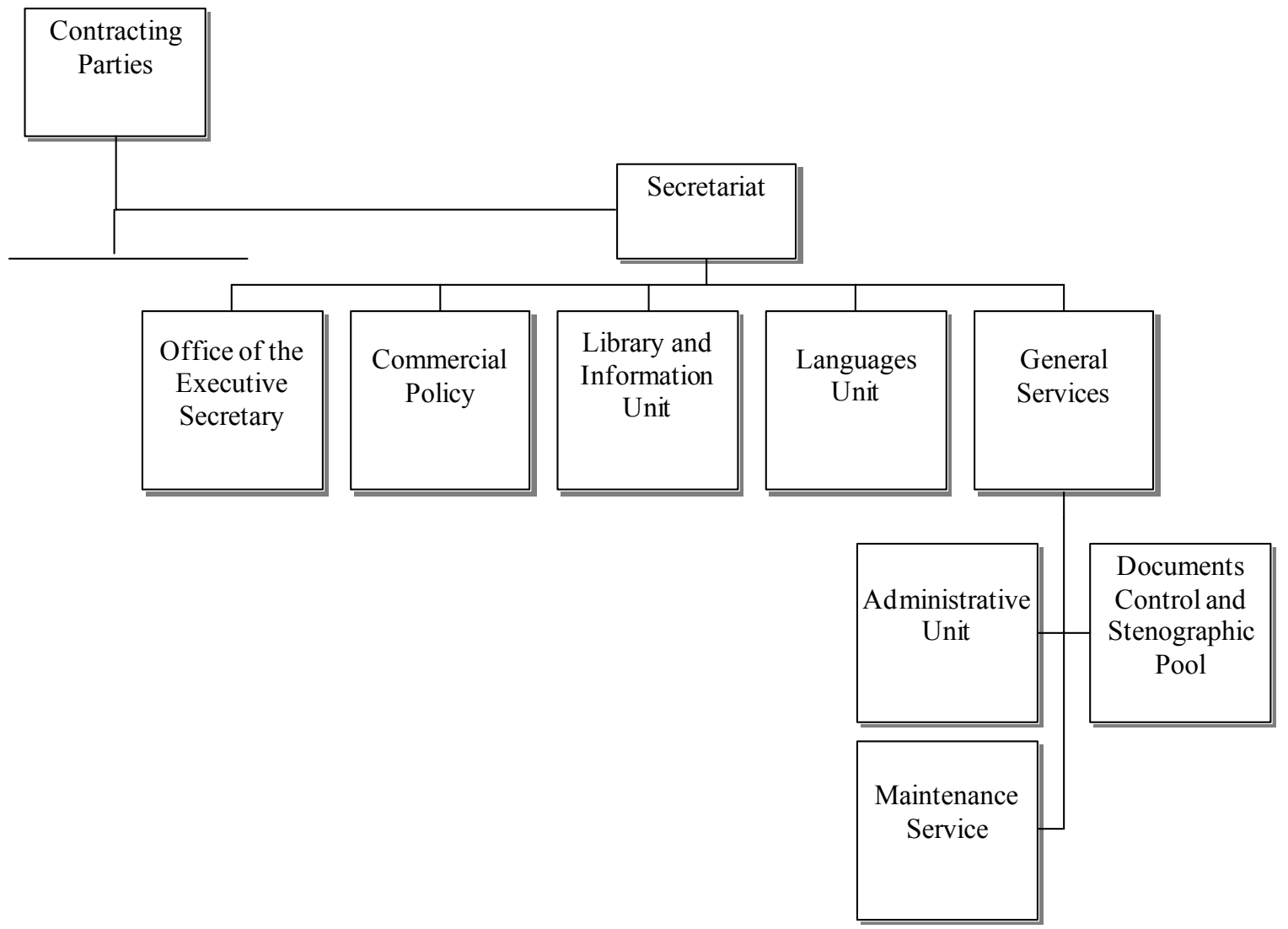




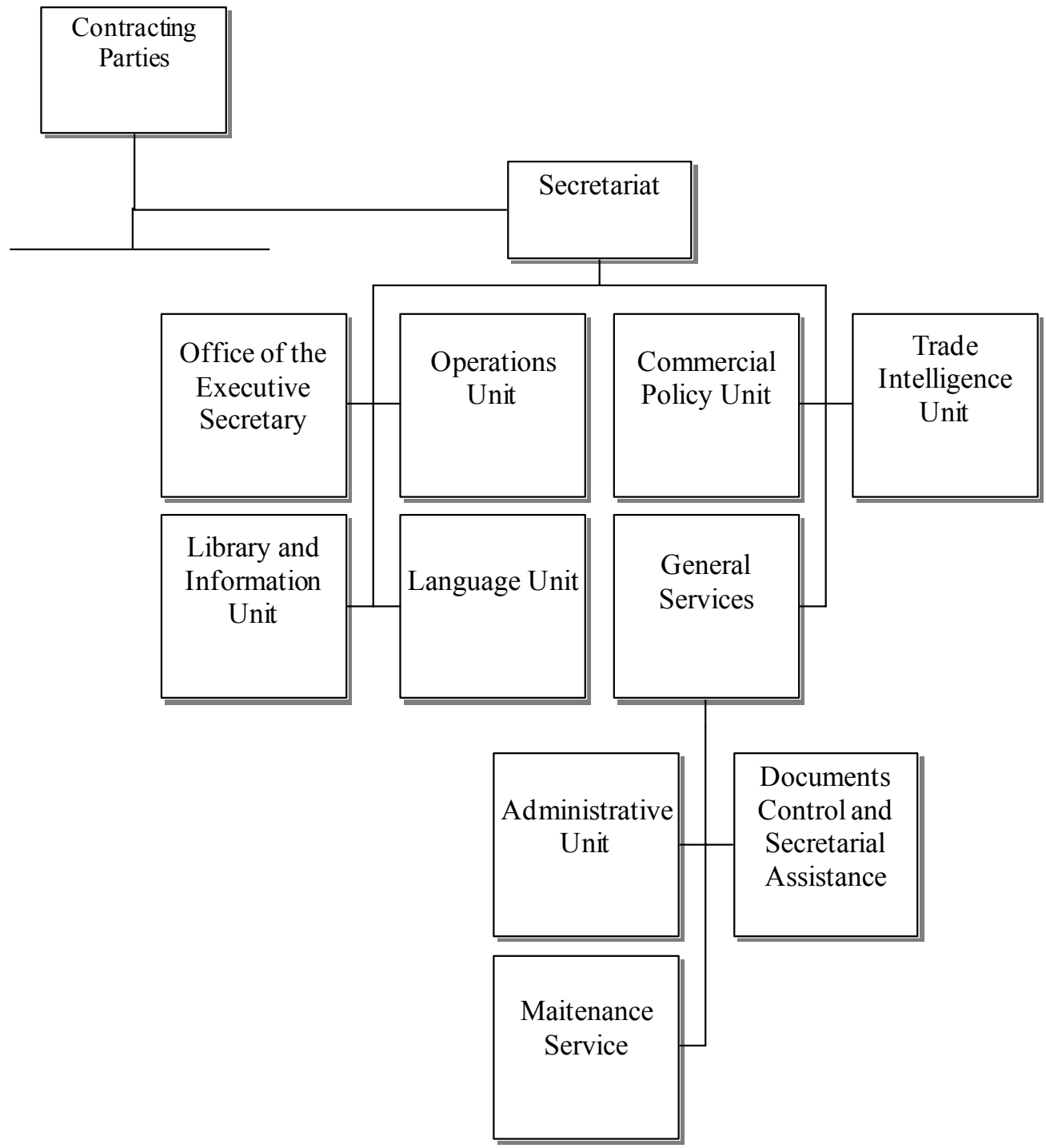




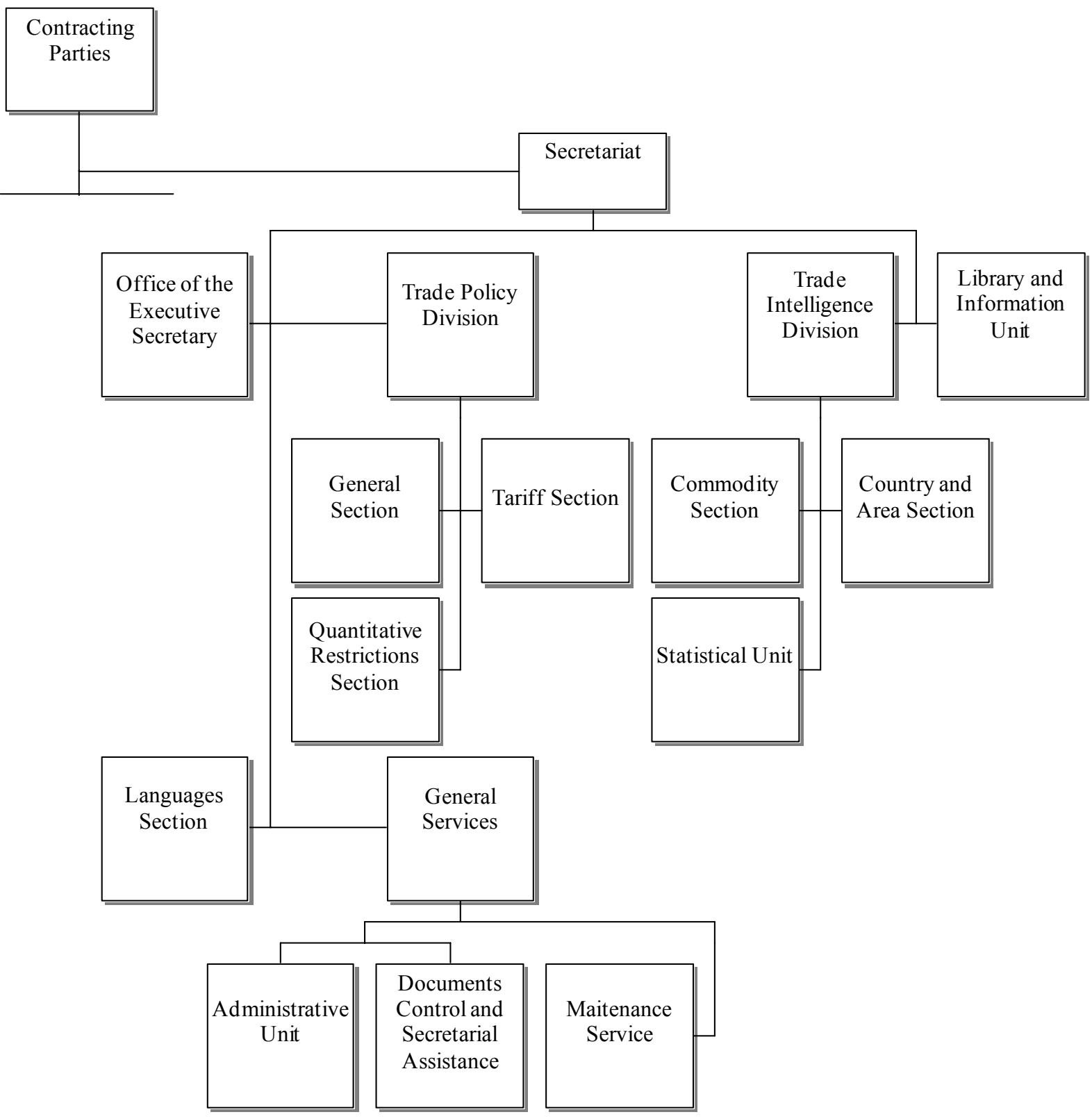




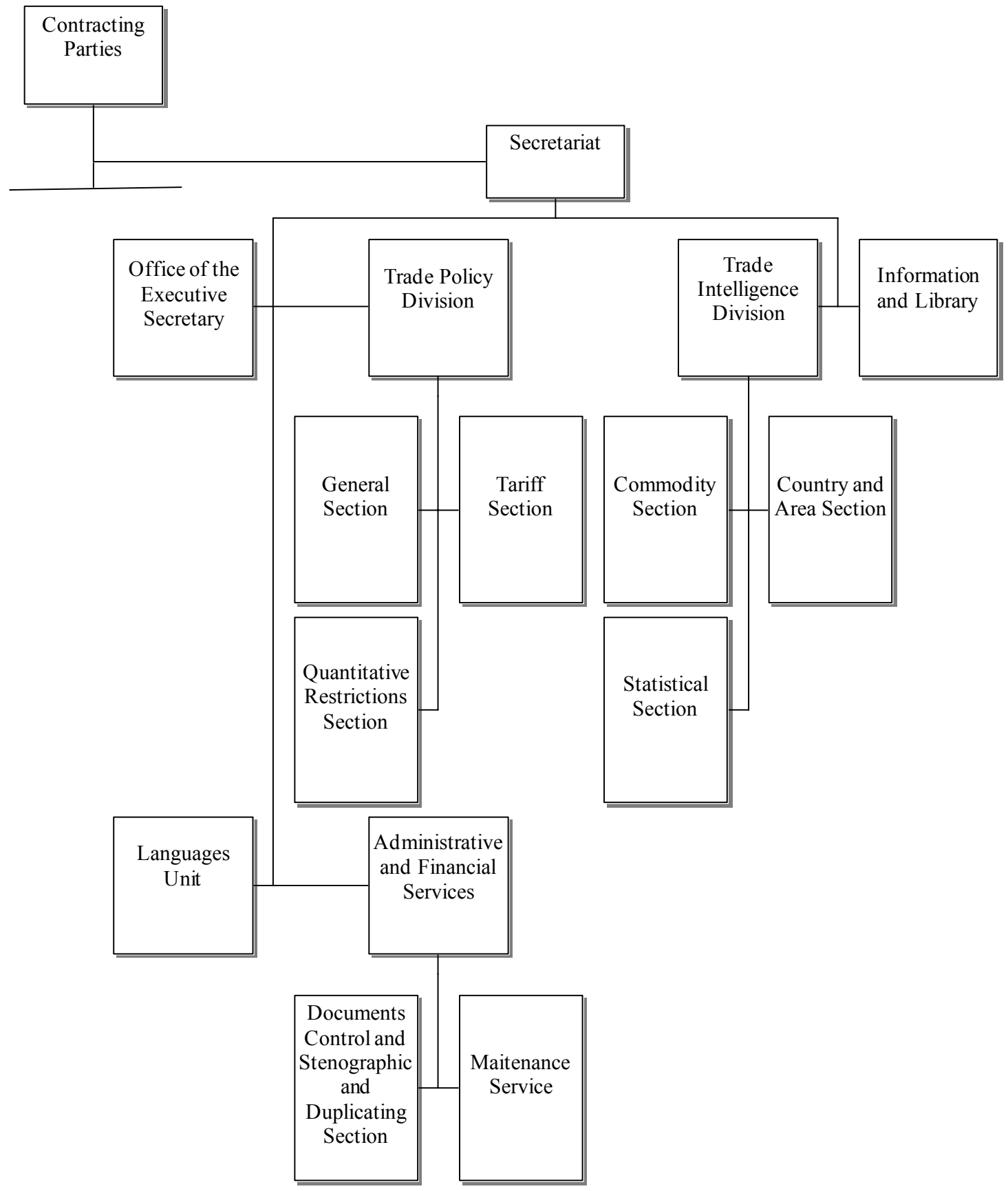




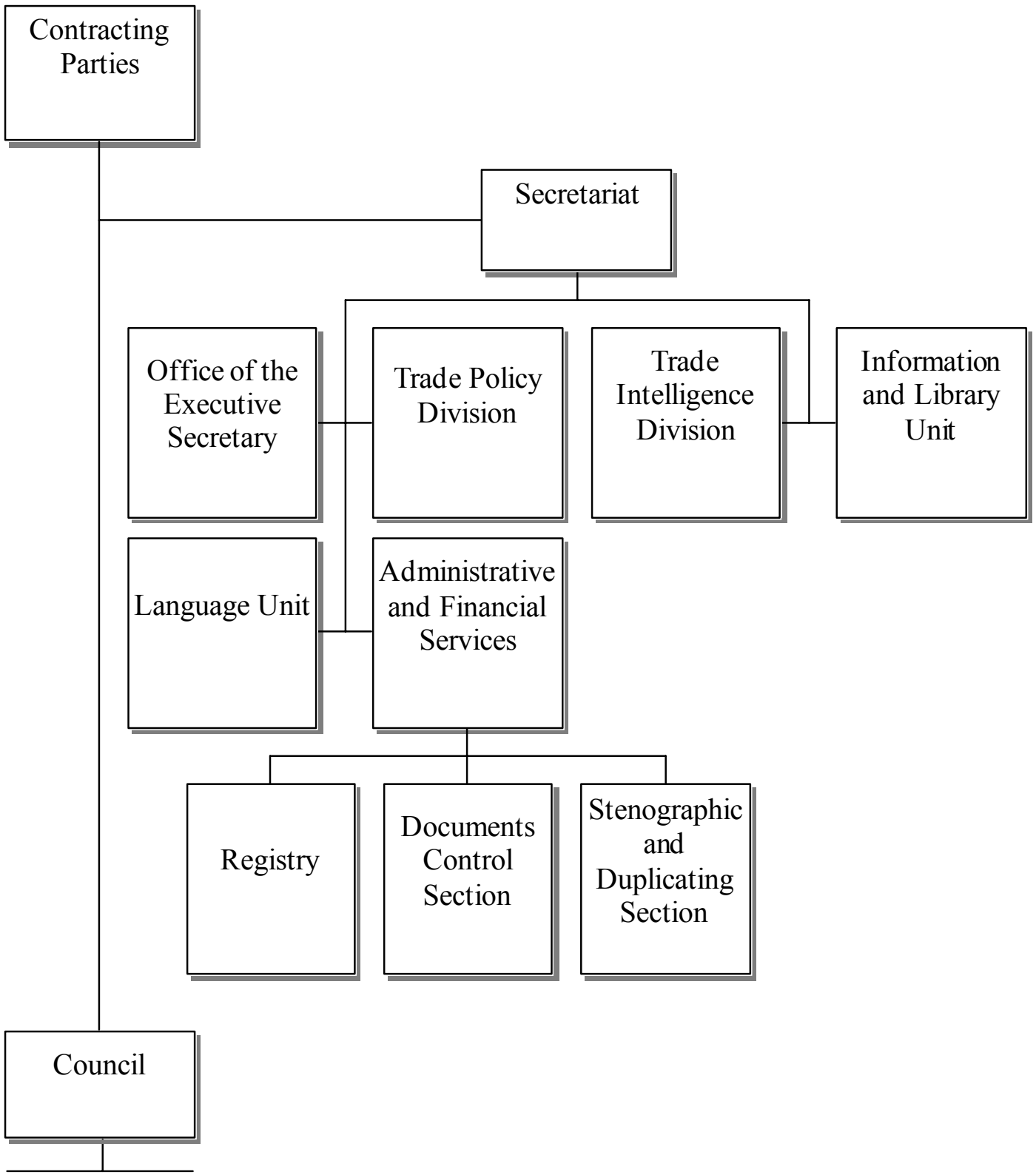




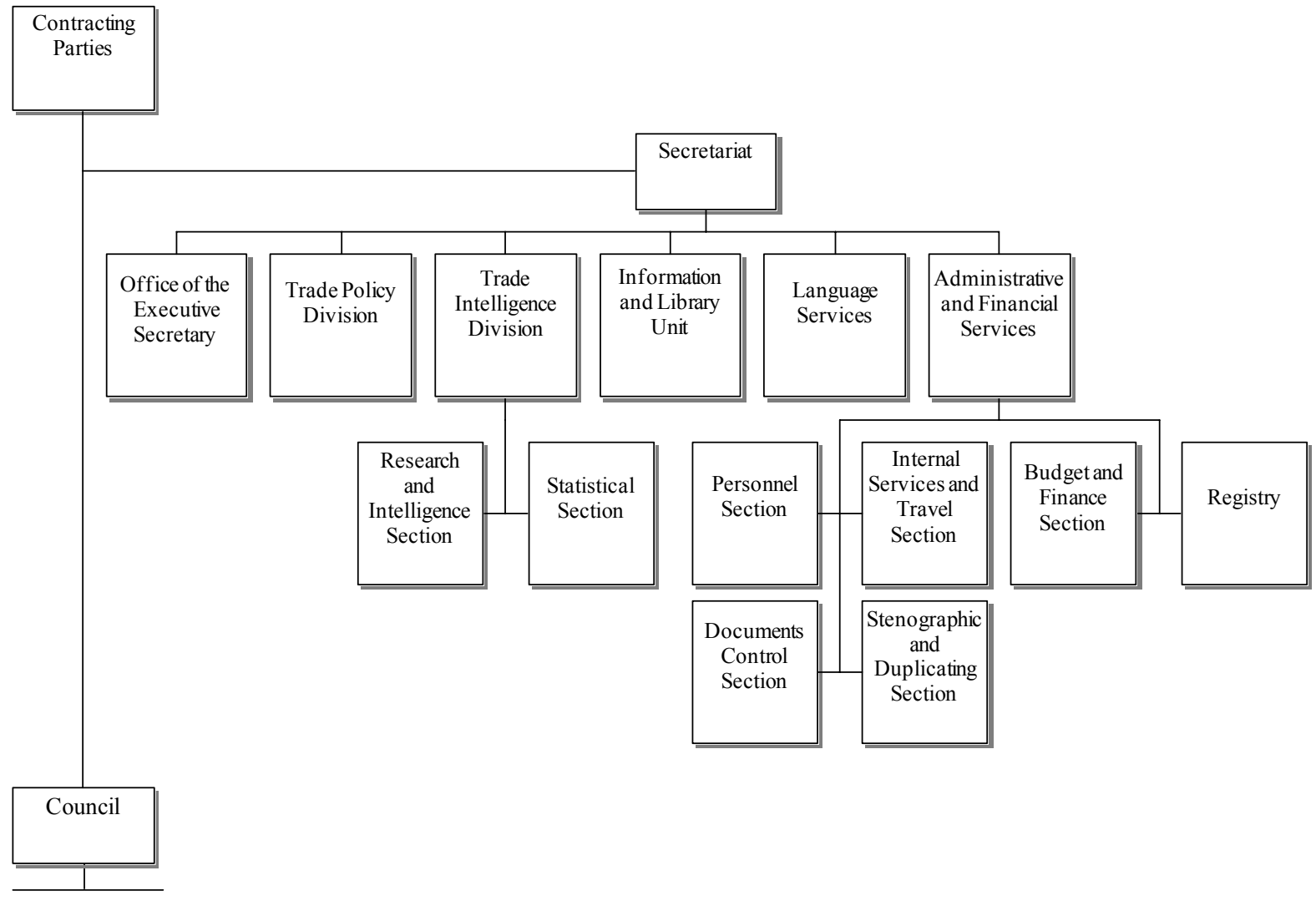




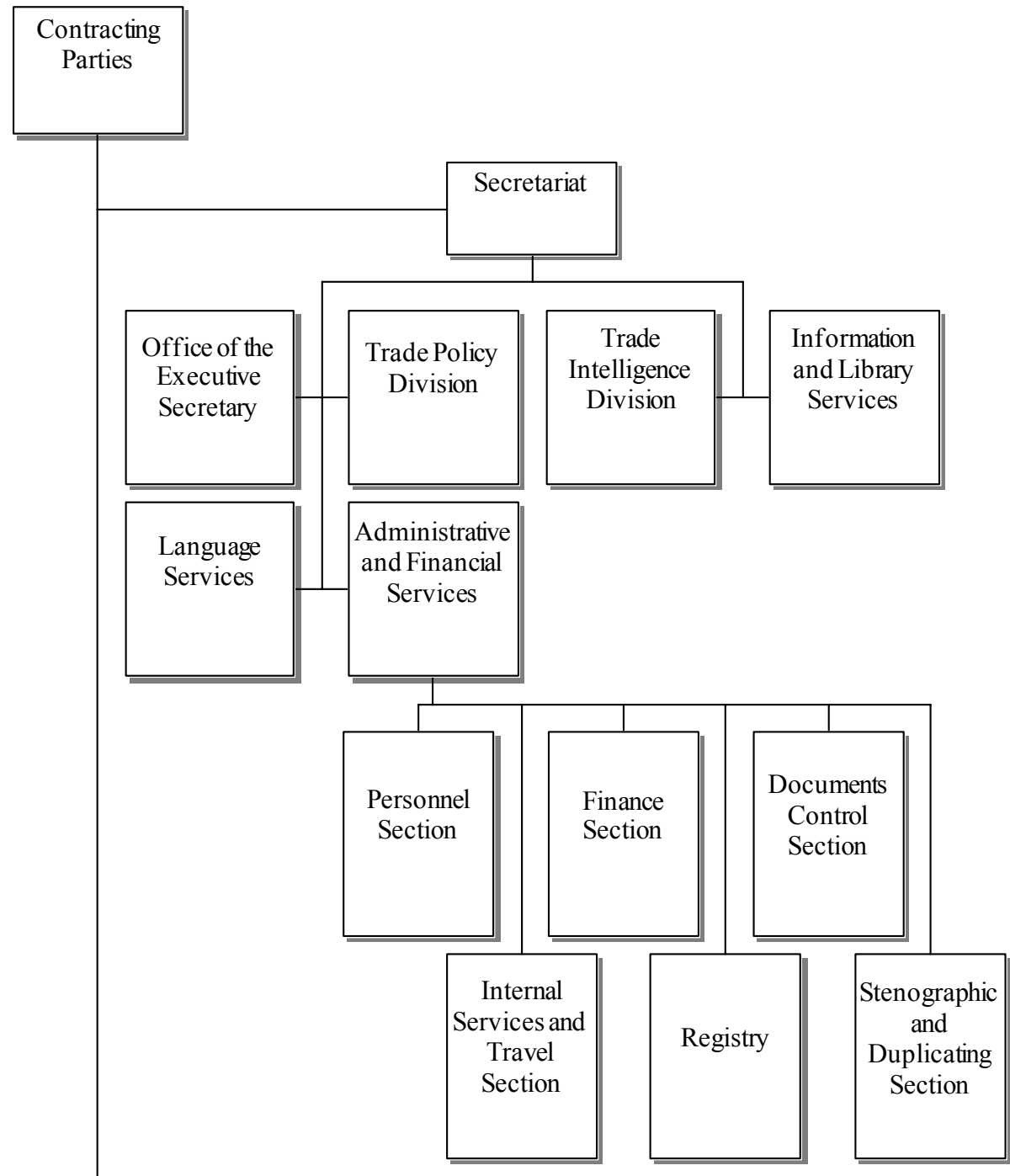

Council 
Ontracting

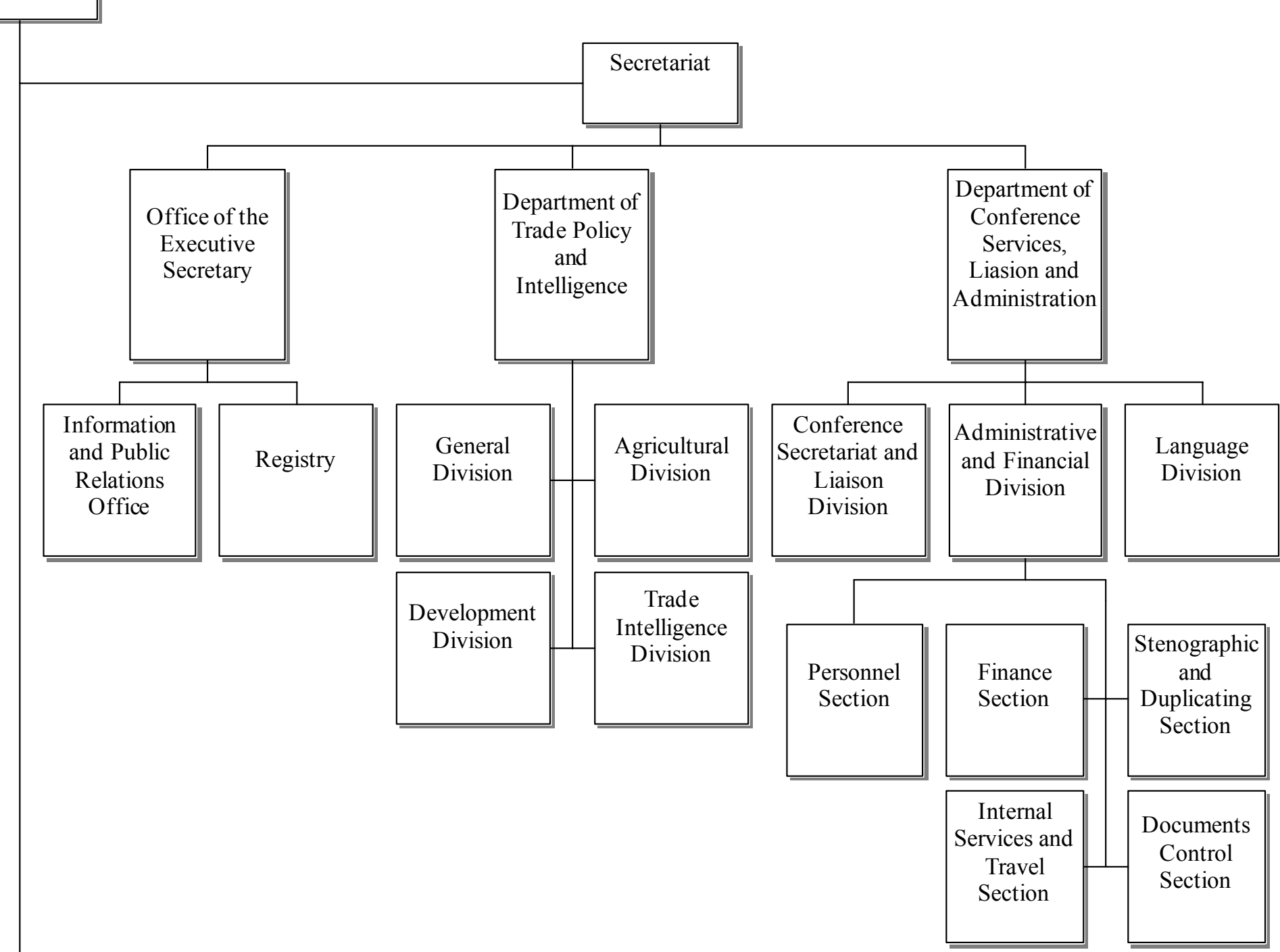




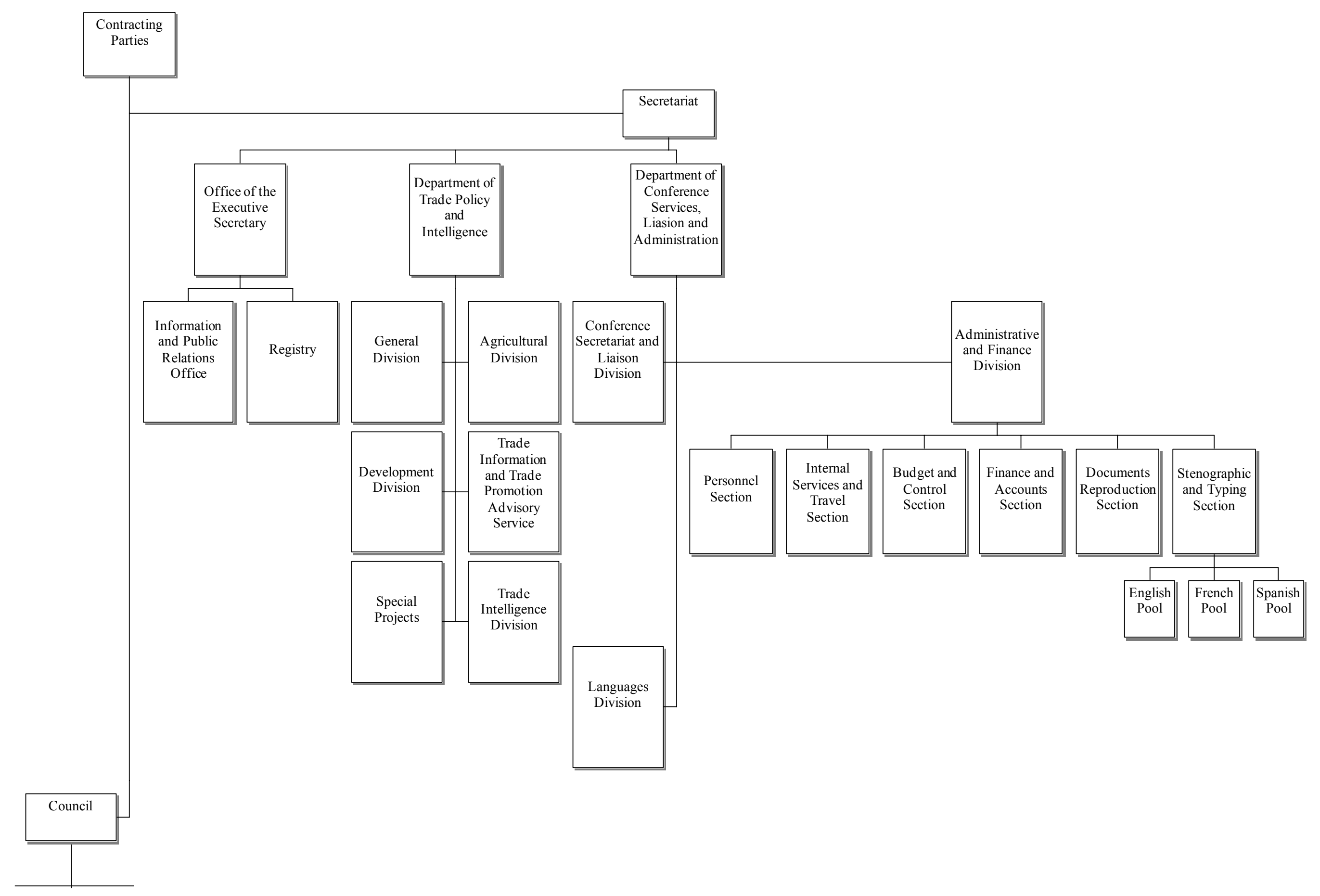




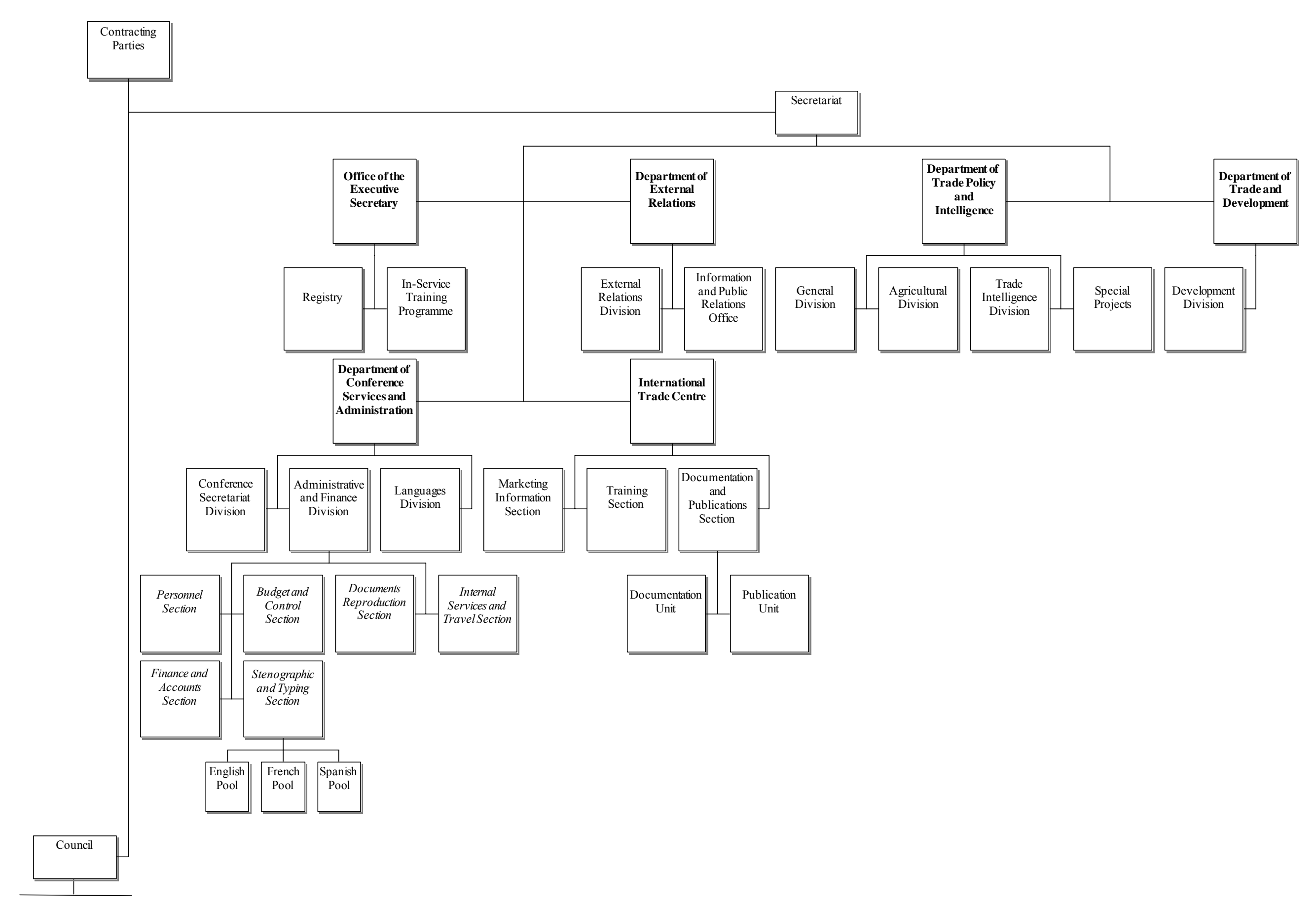




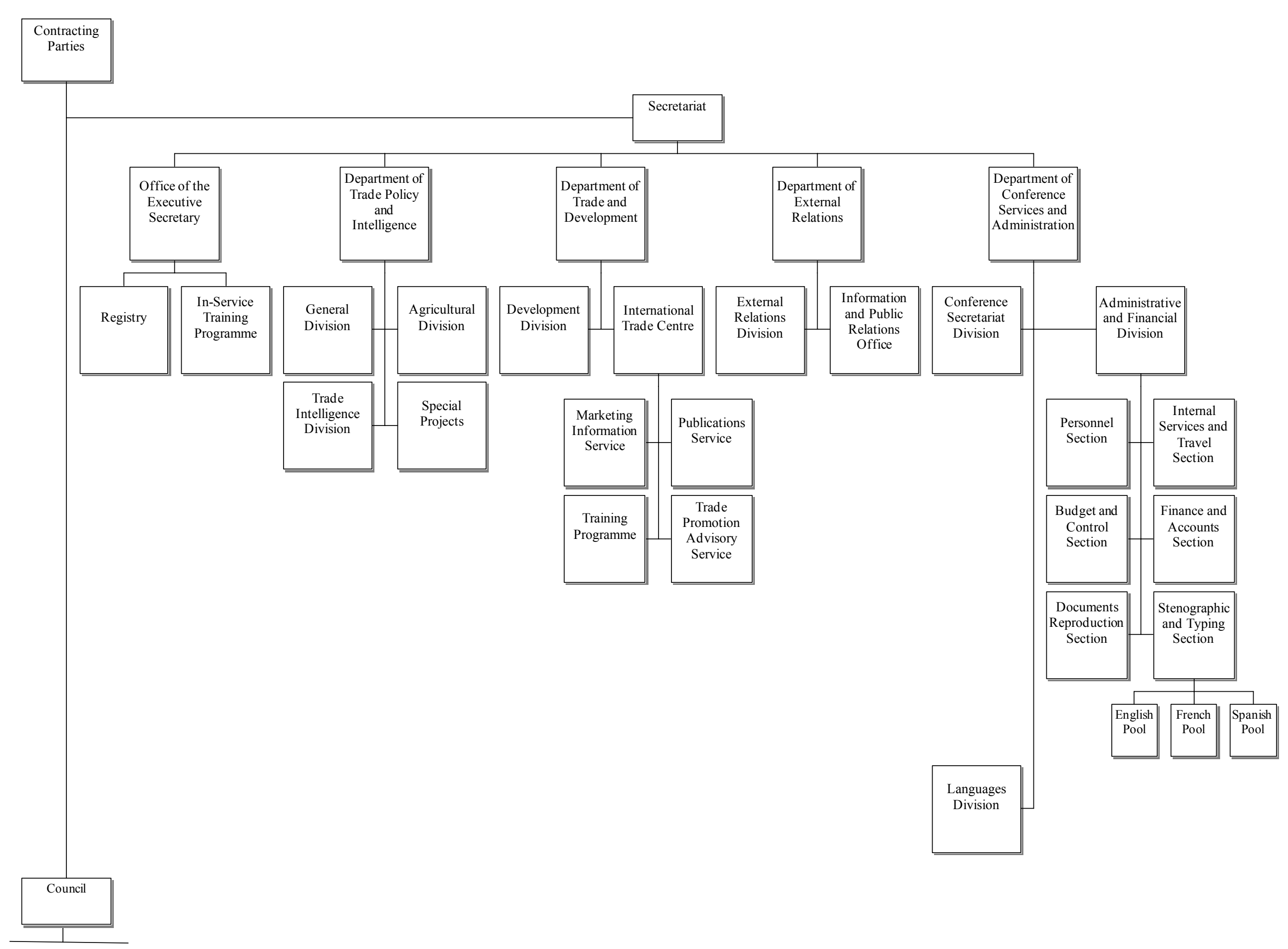




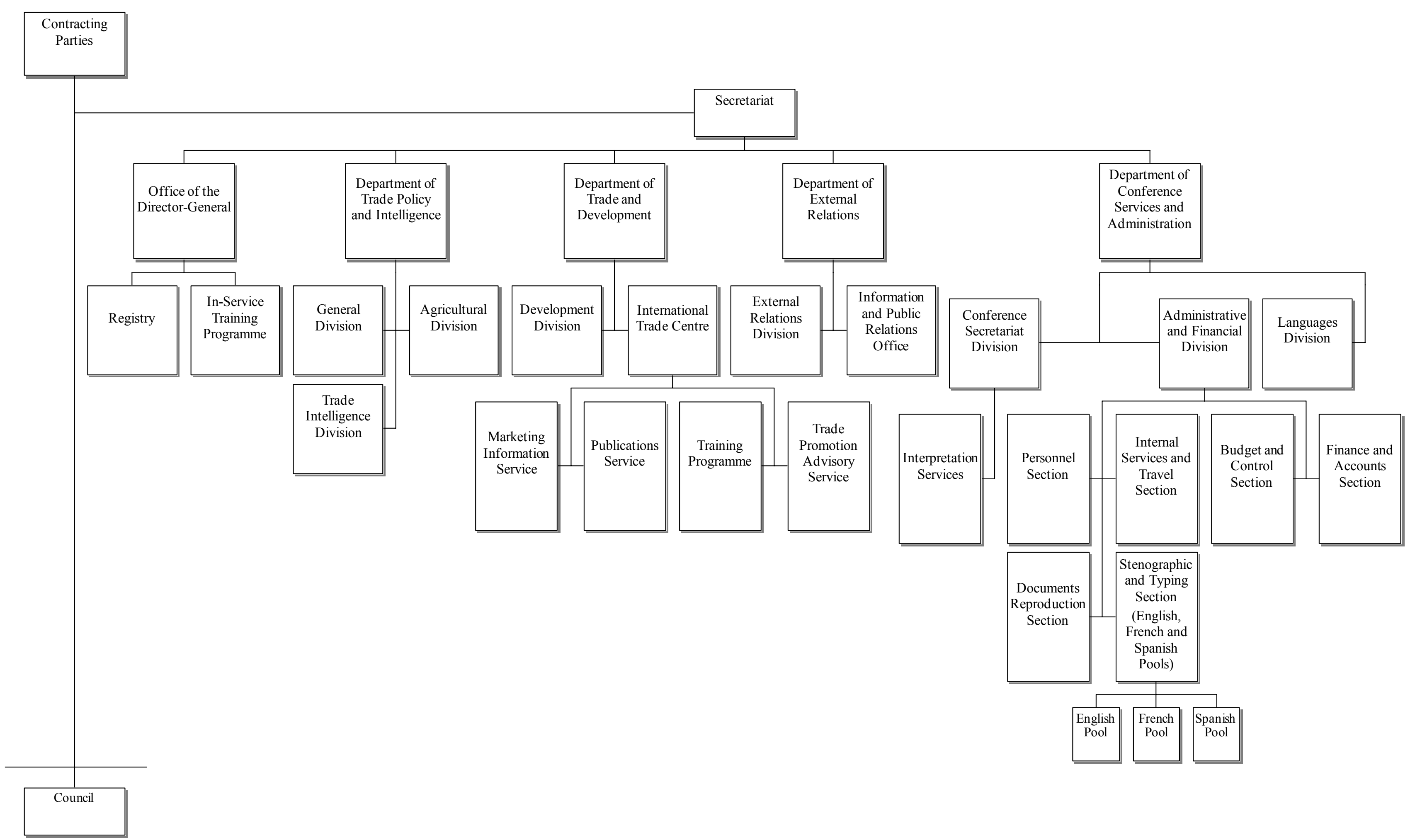




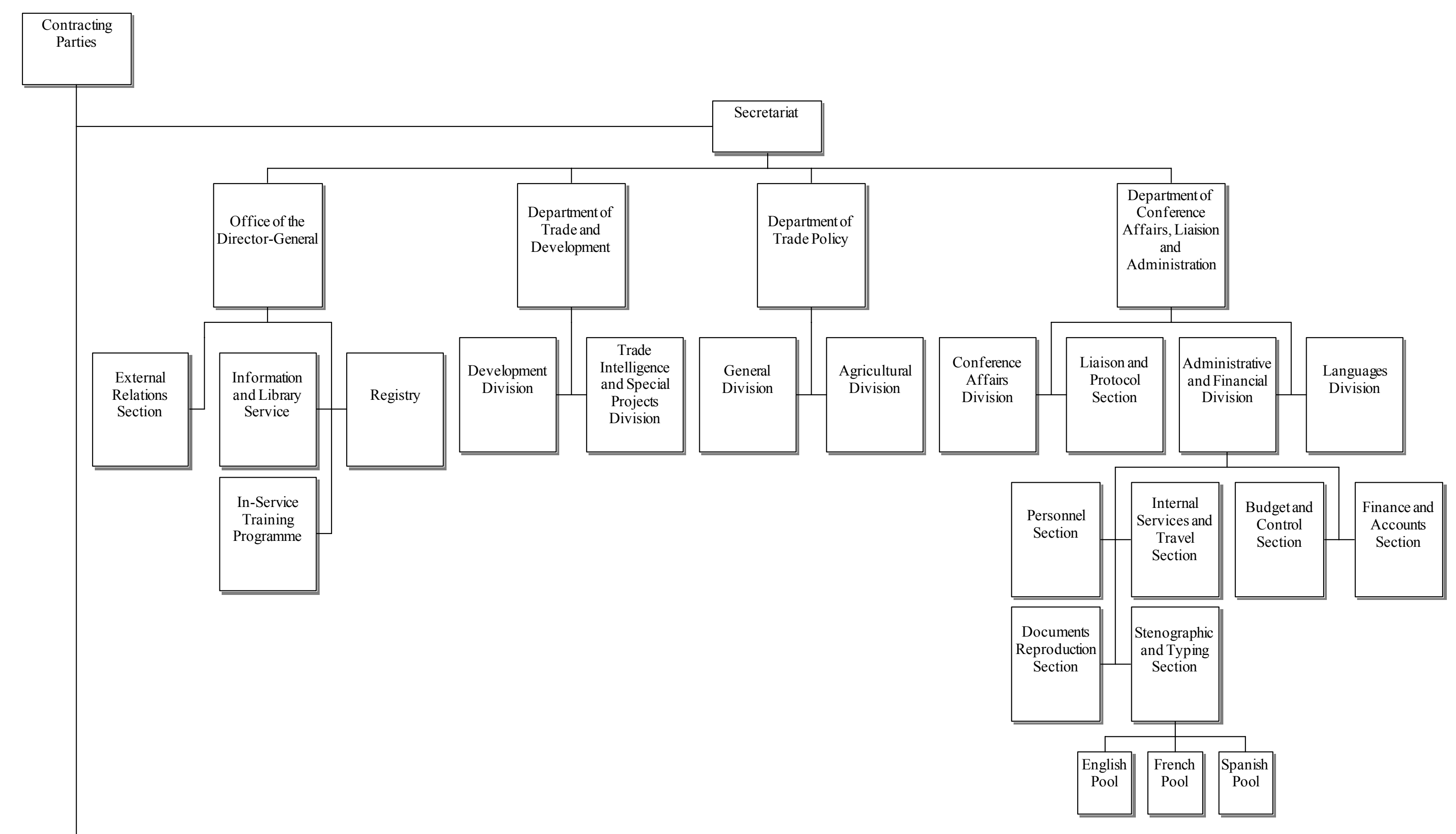




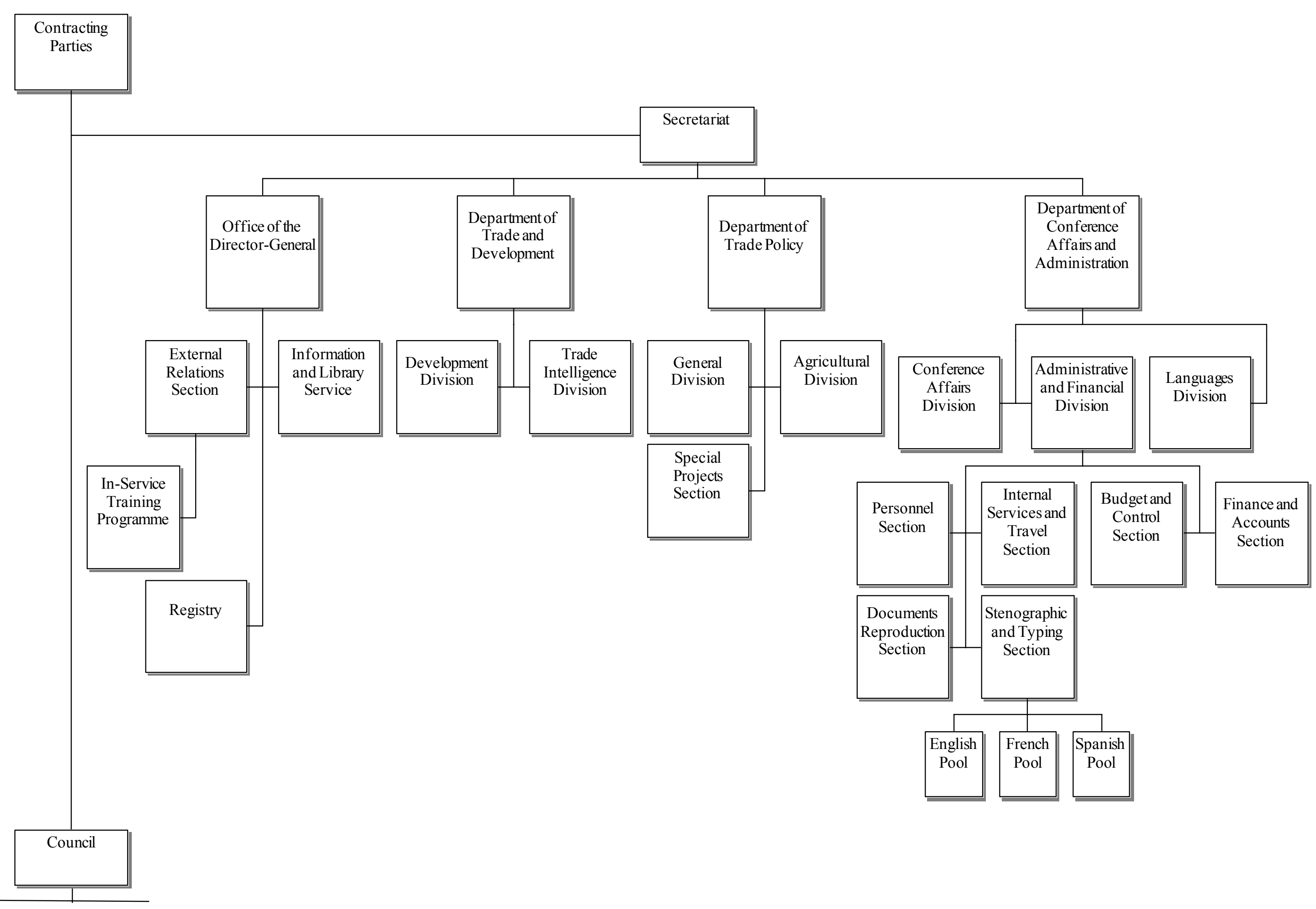




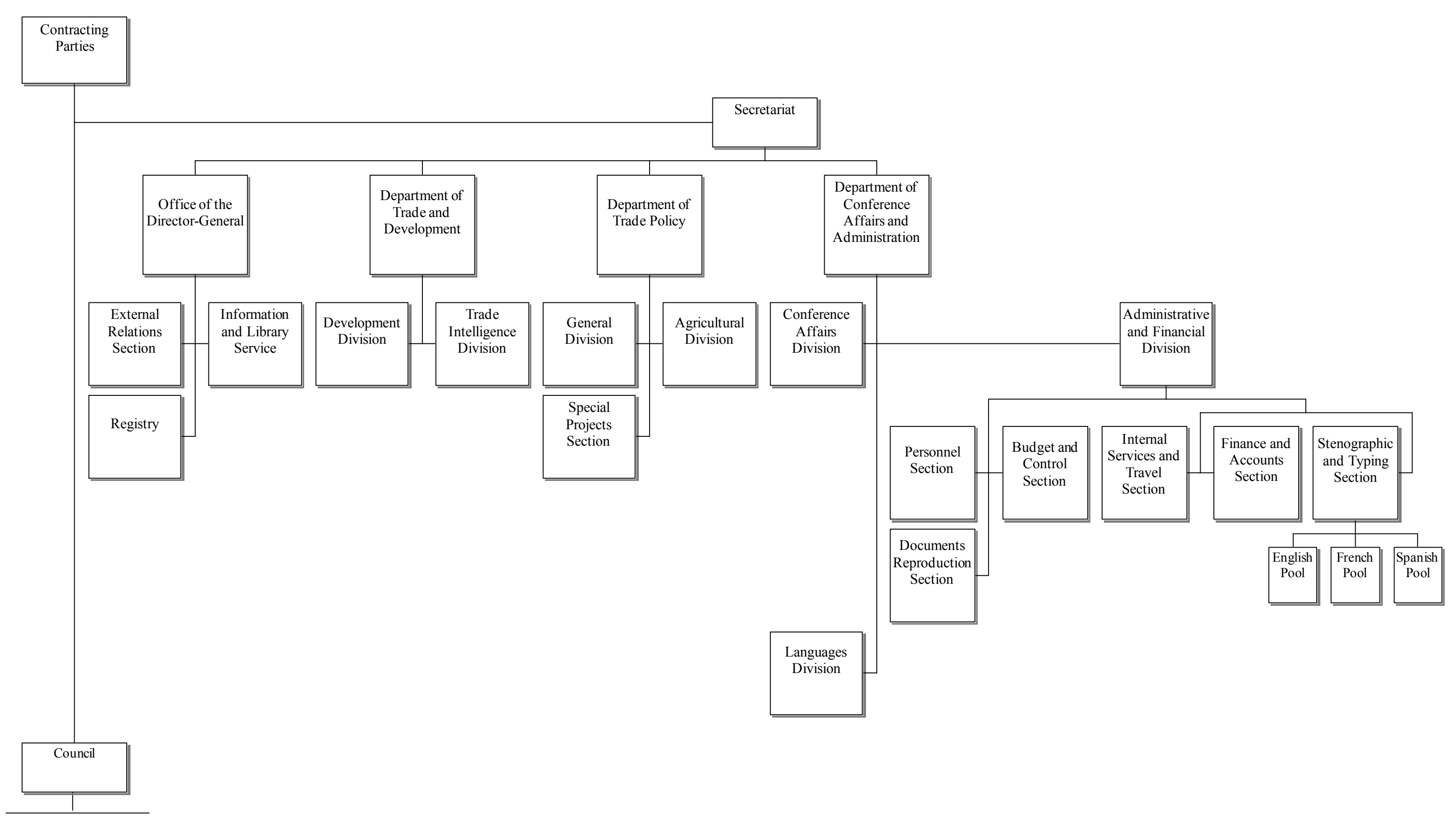




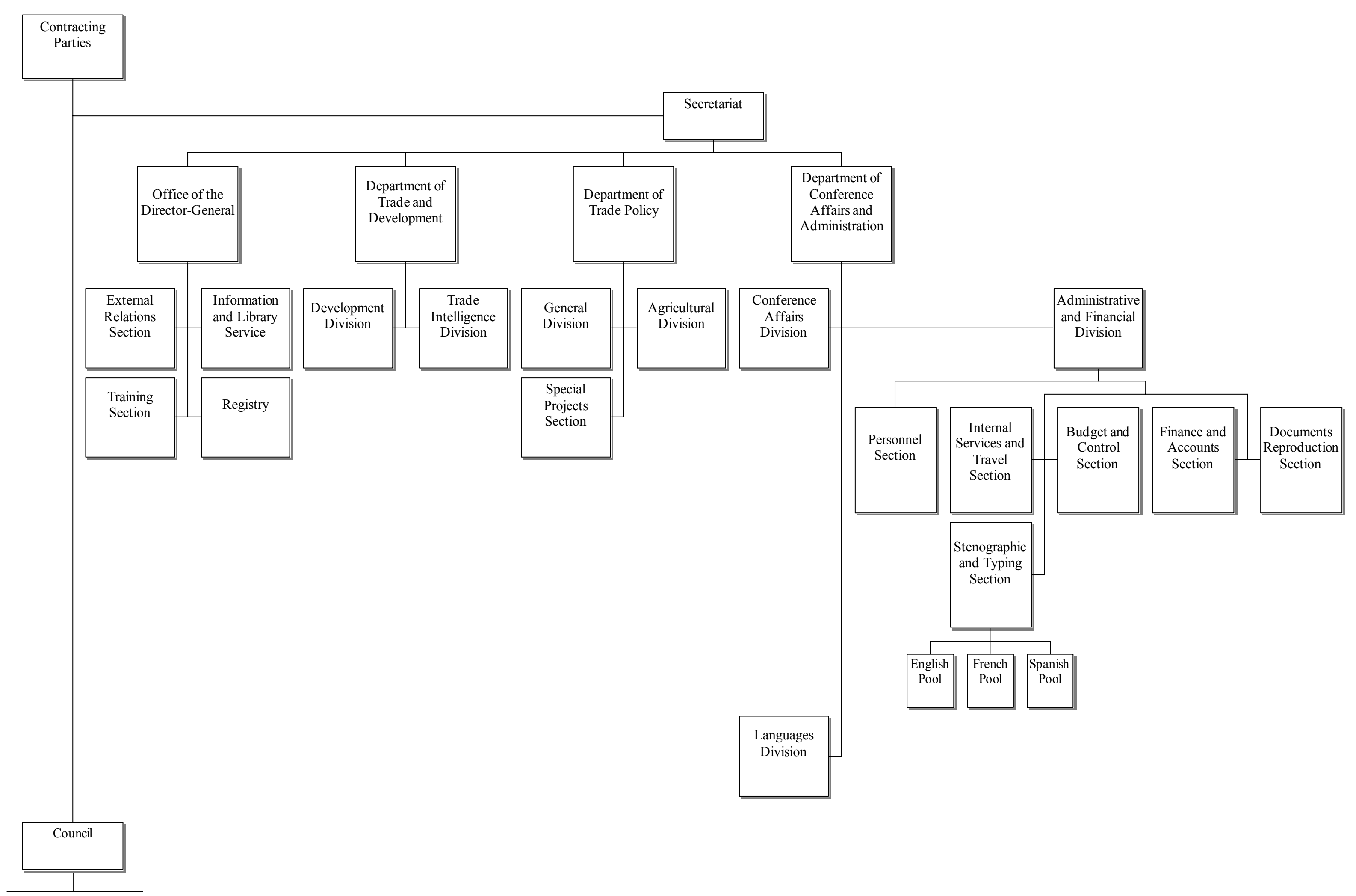




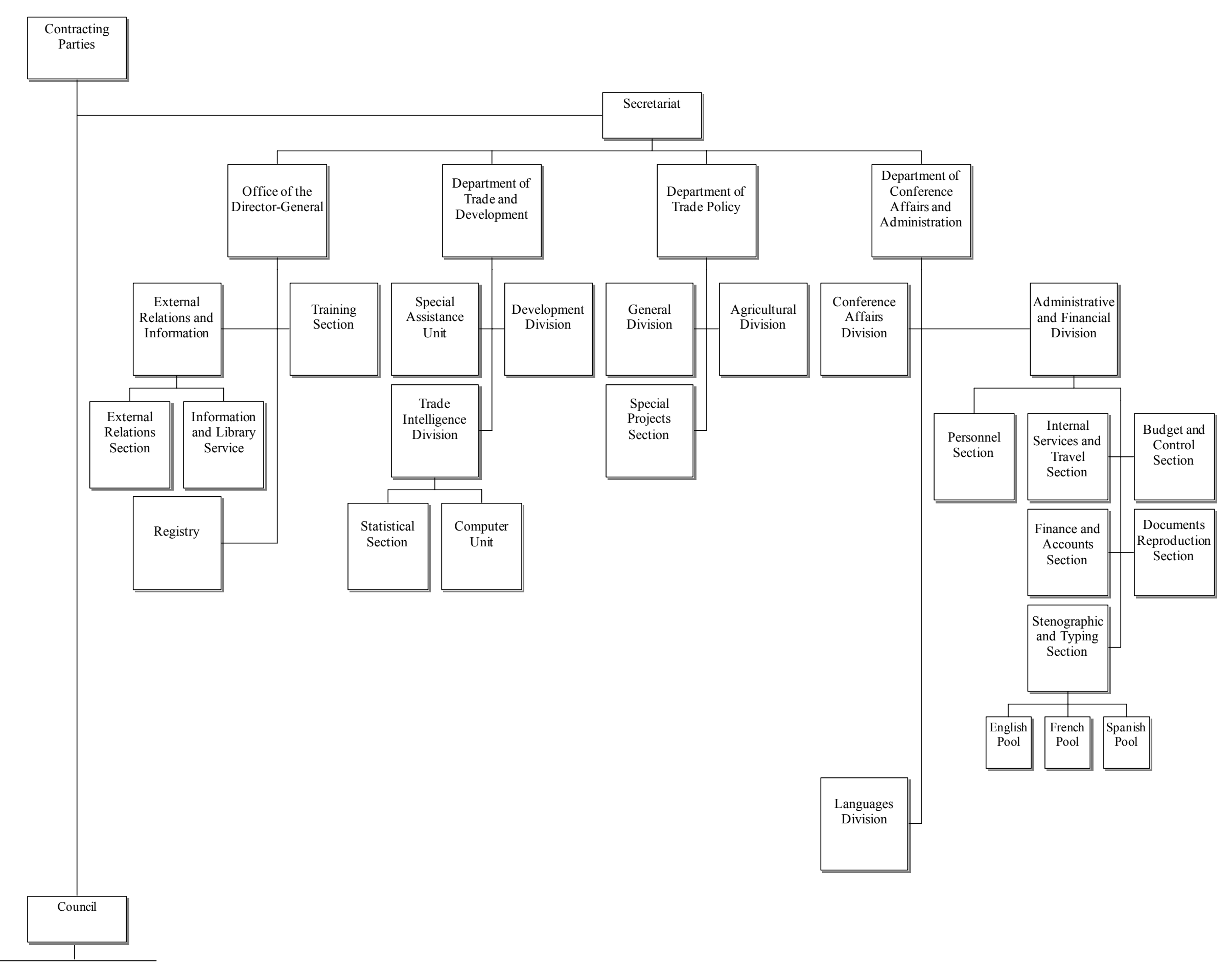




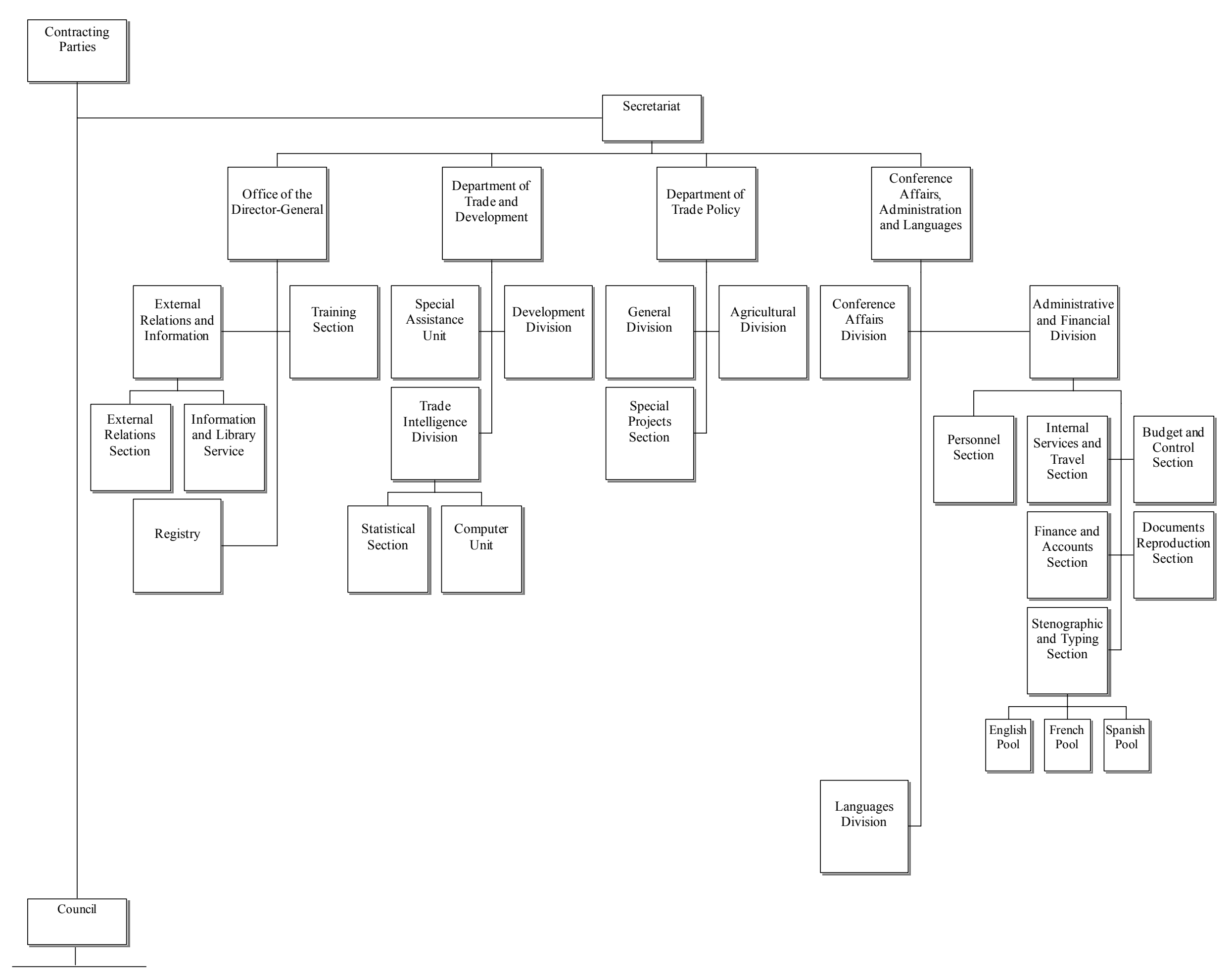




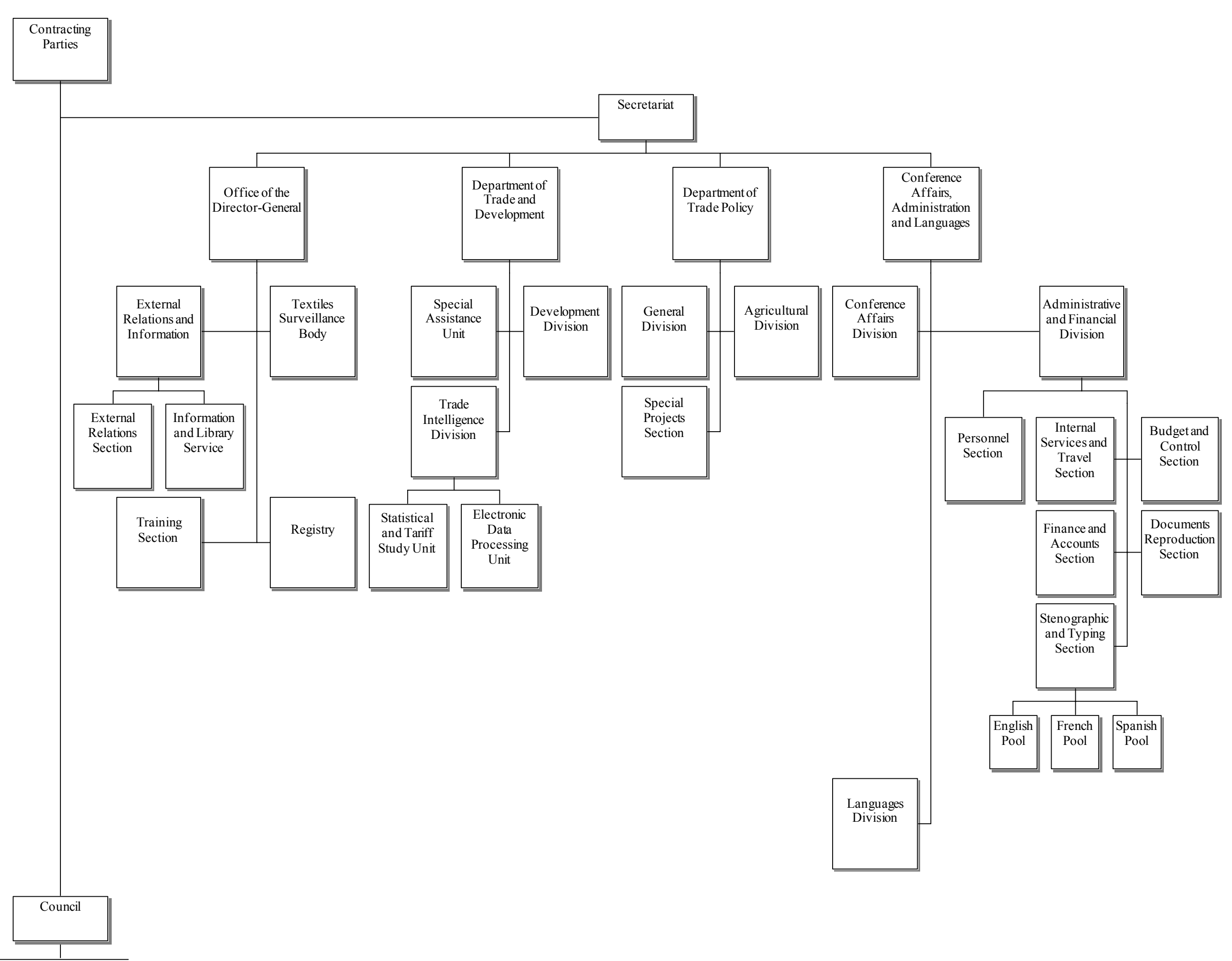




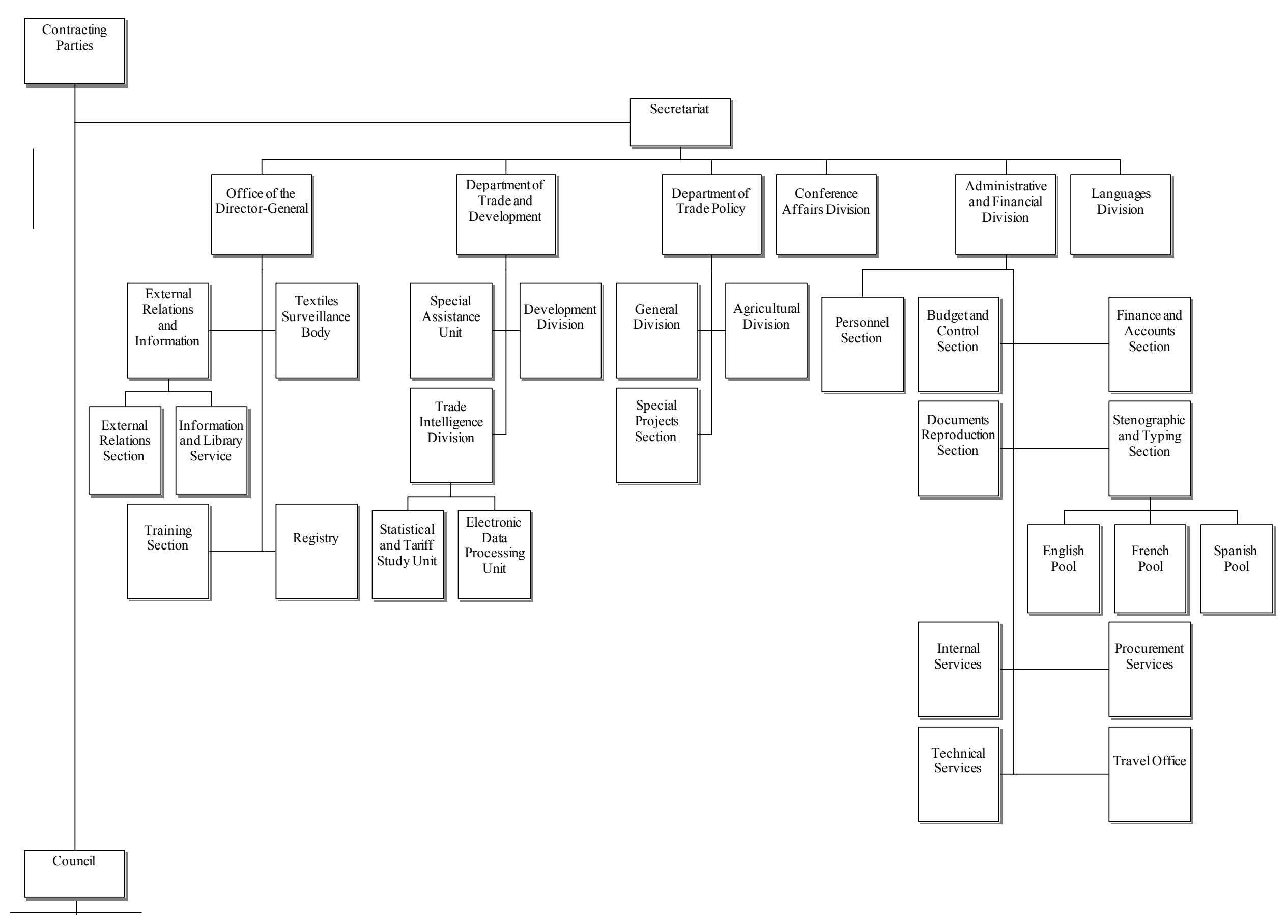




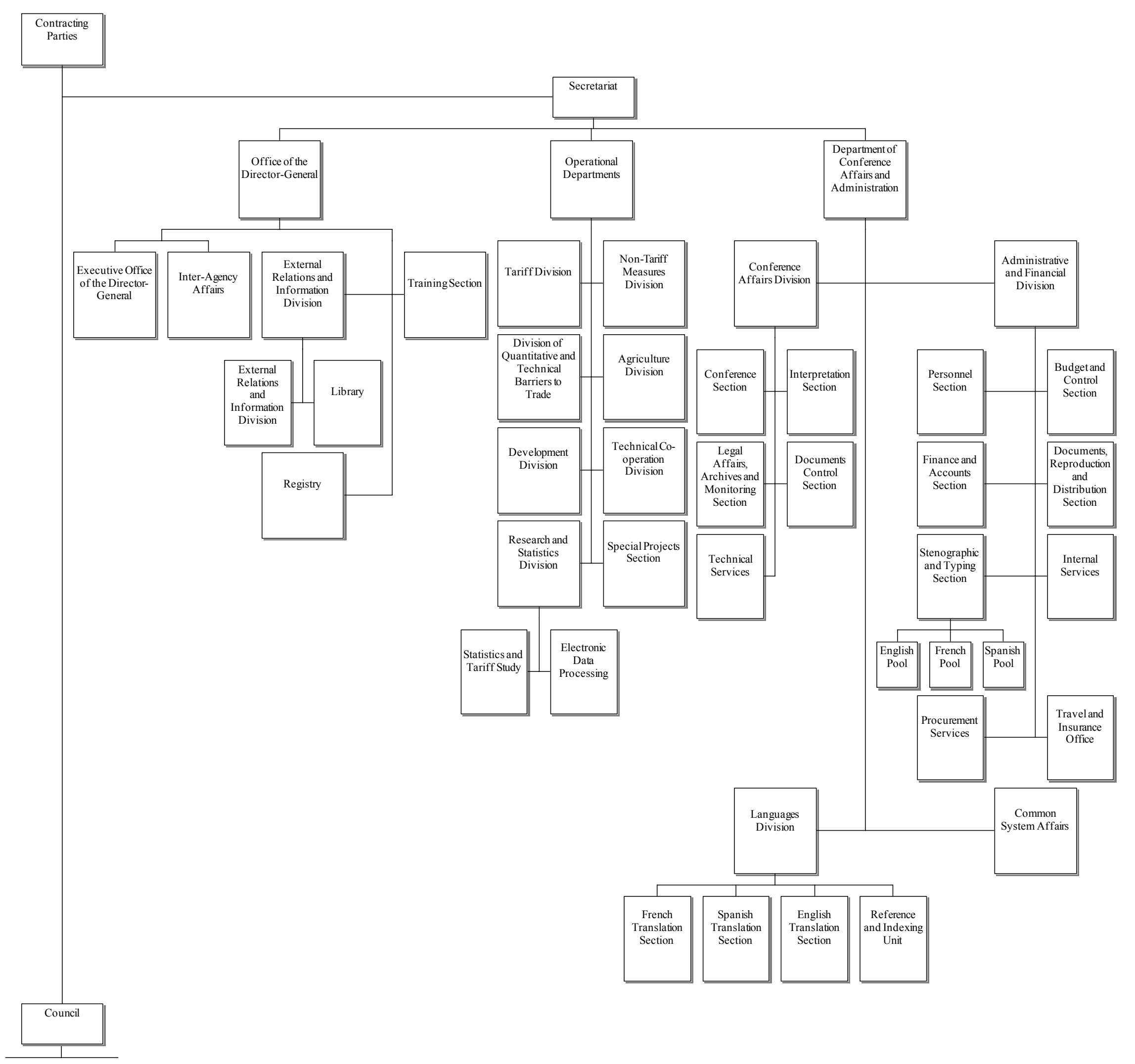




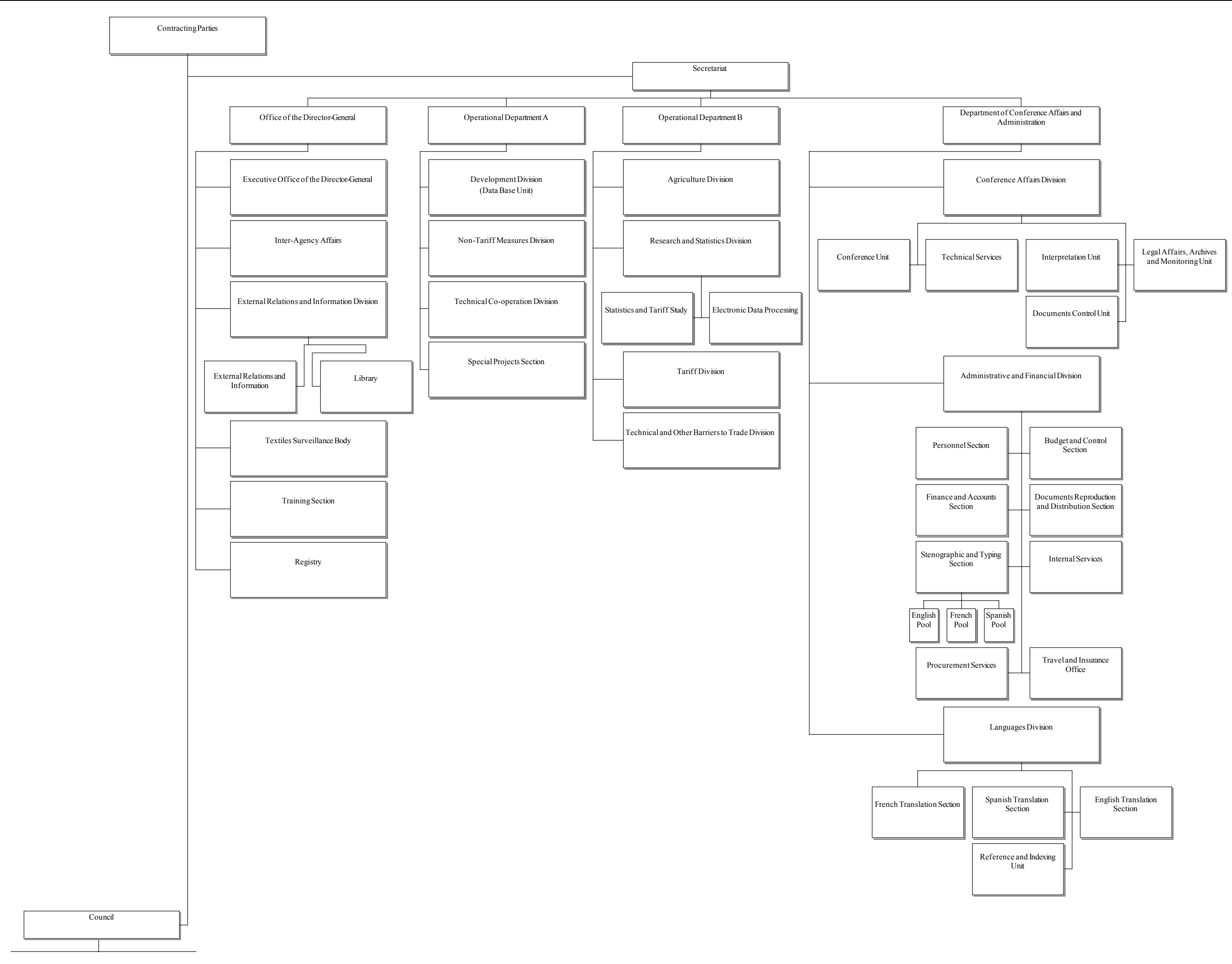




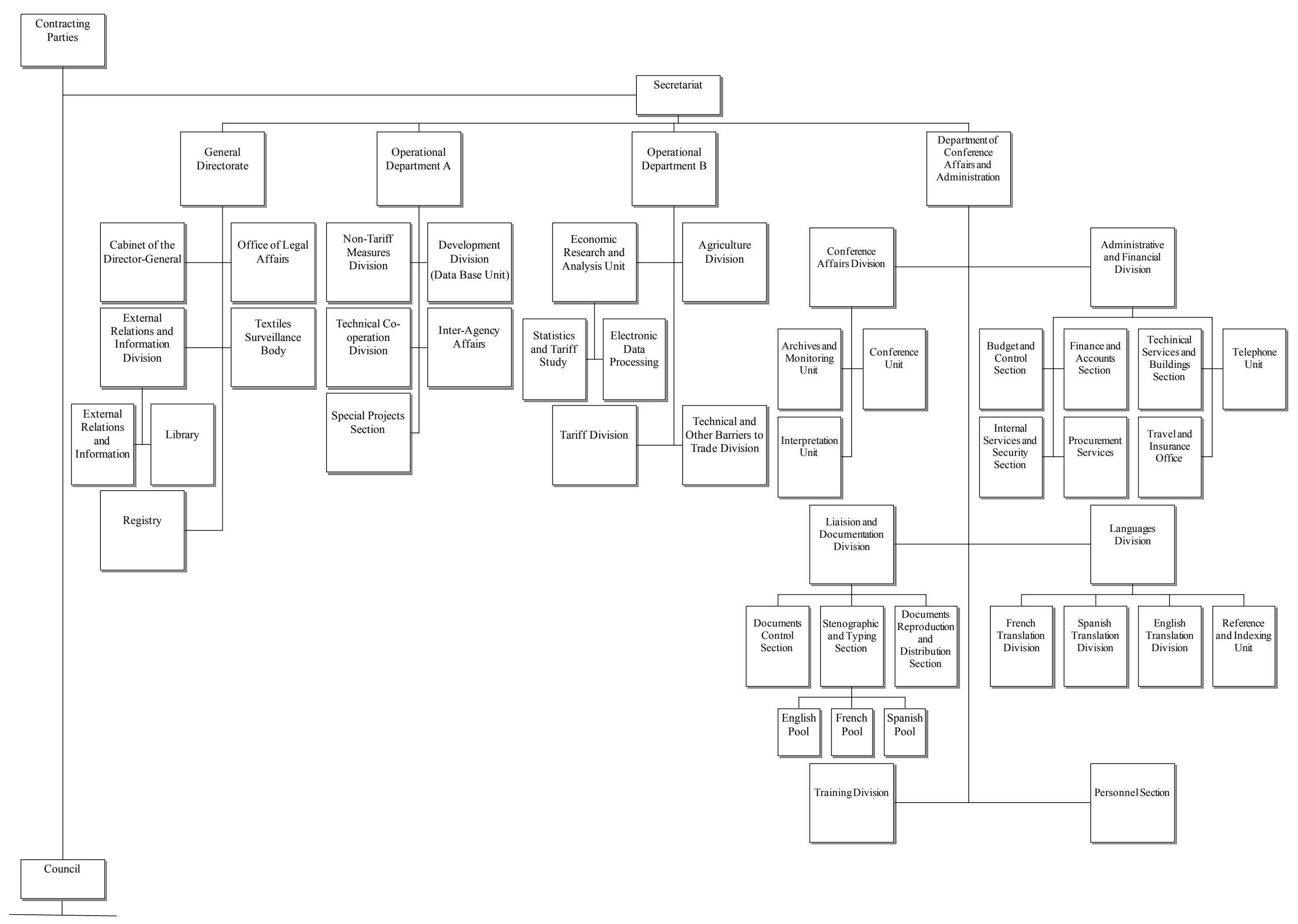


1983

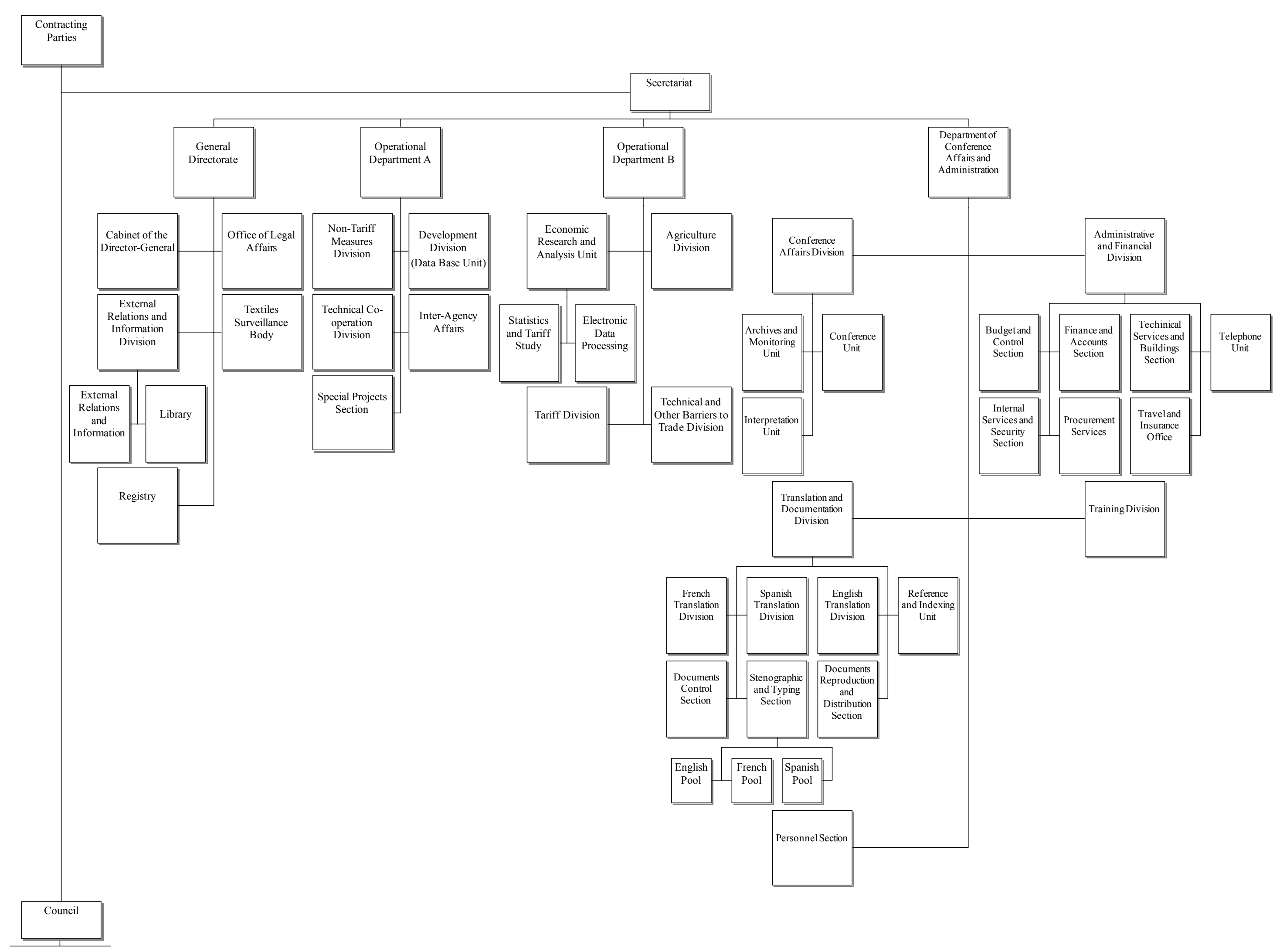




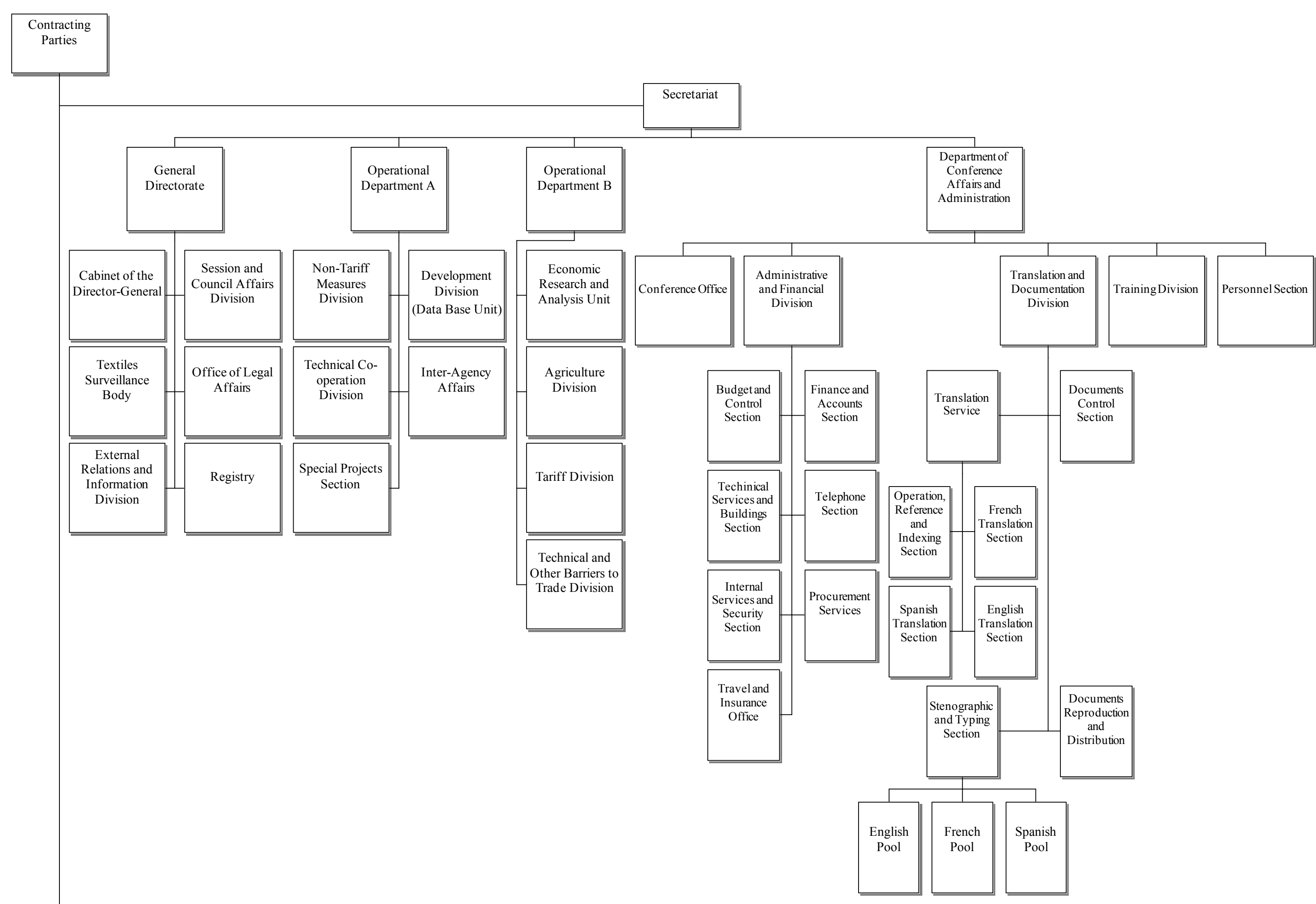




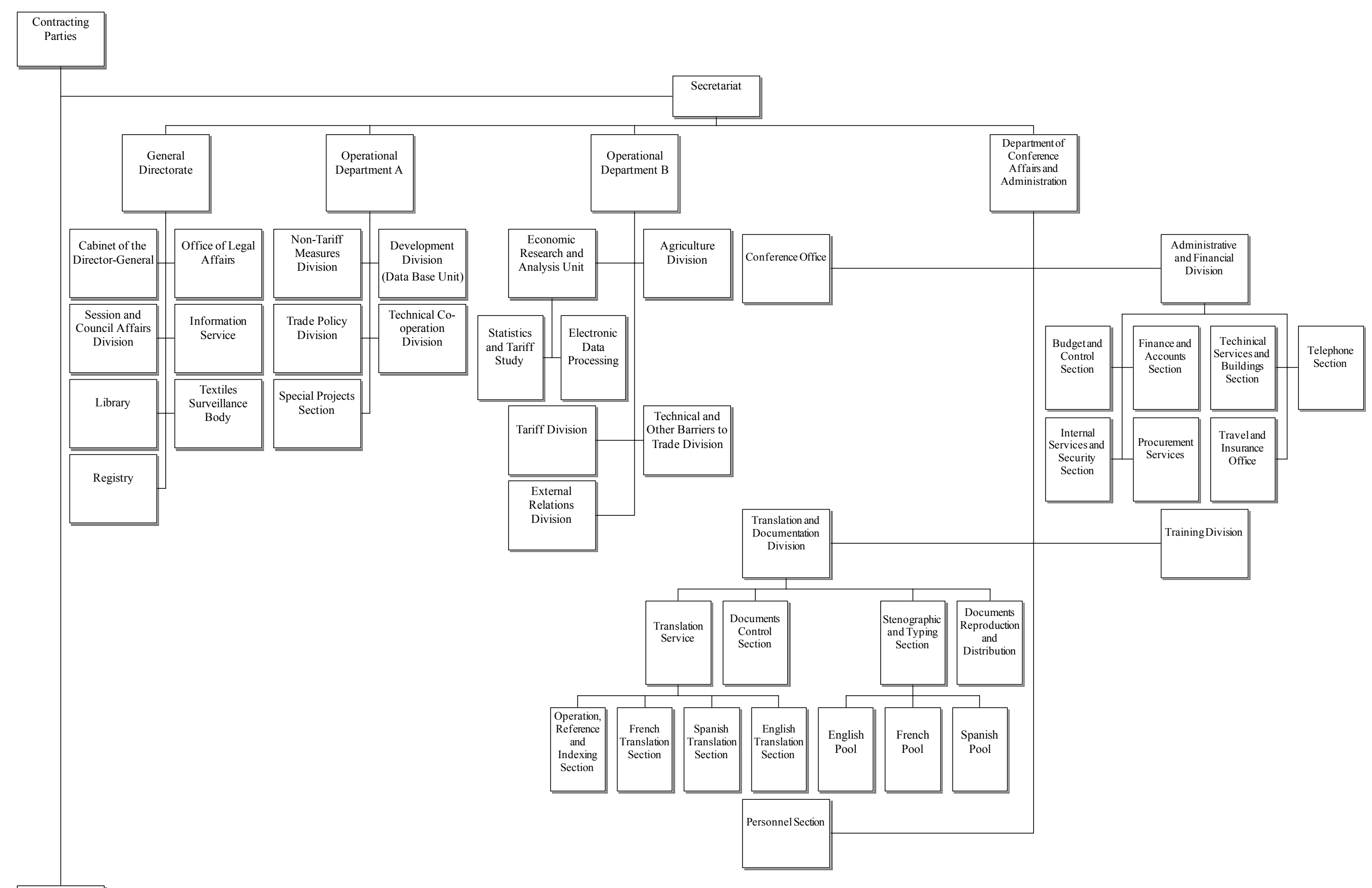




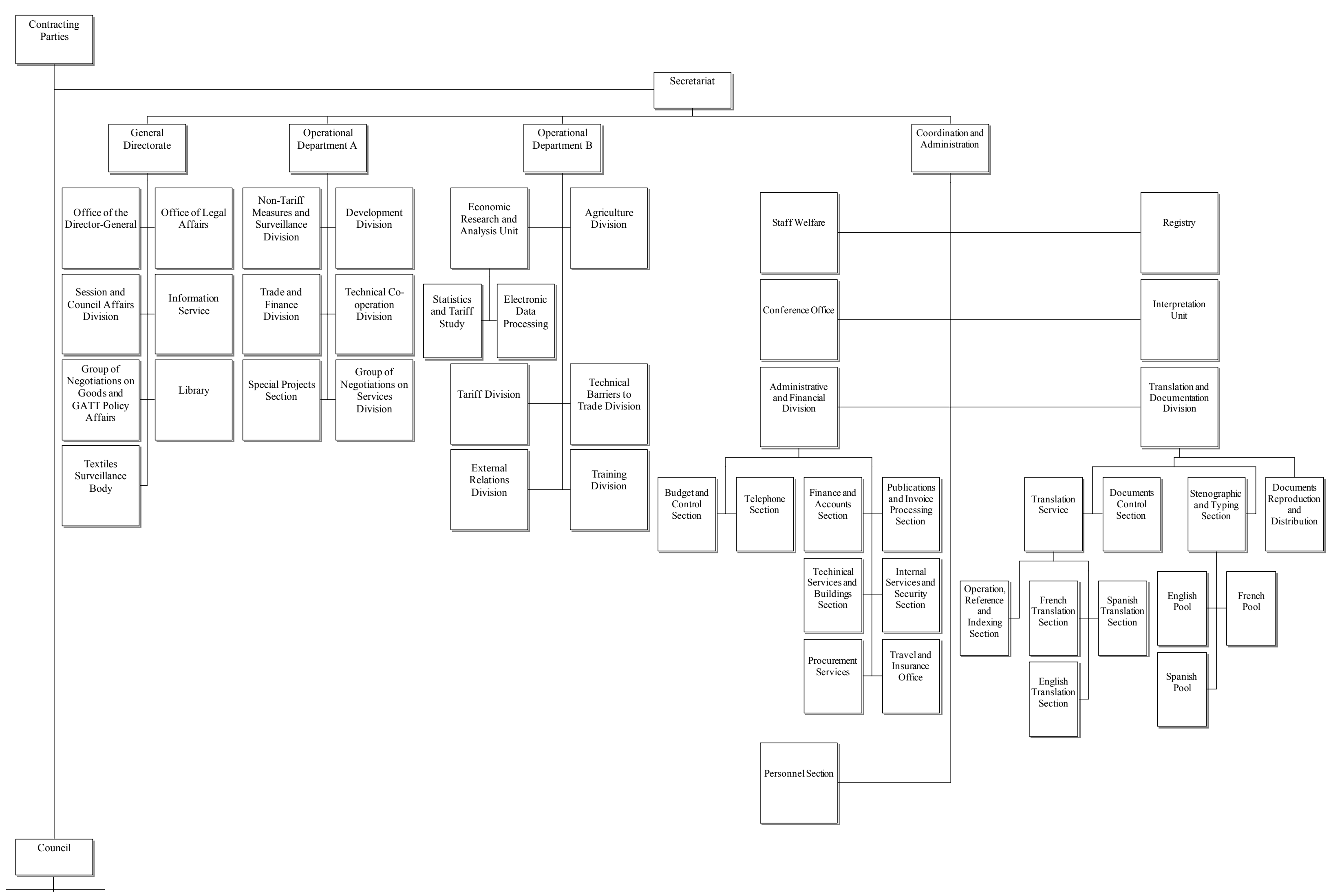




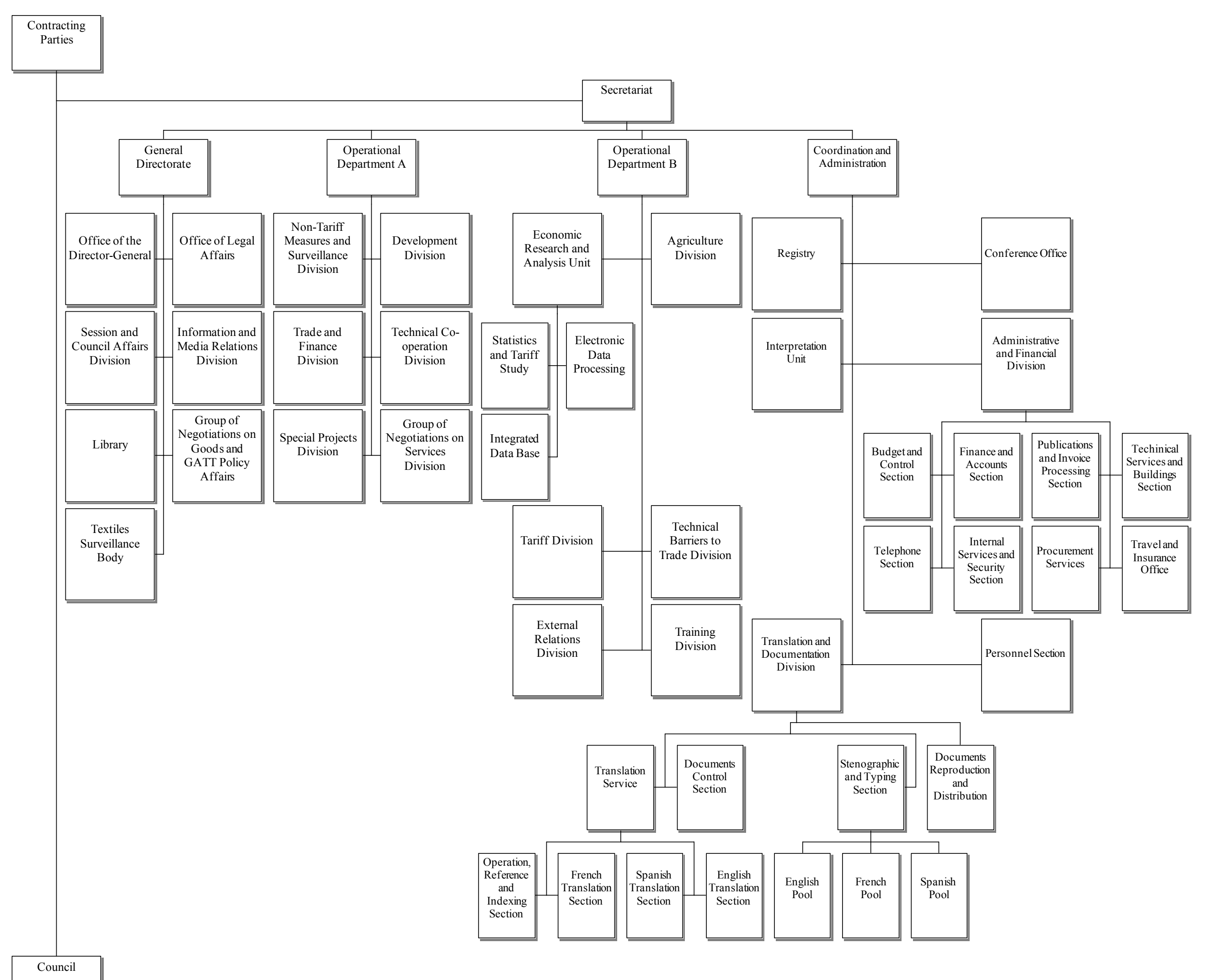




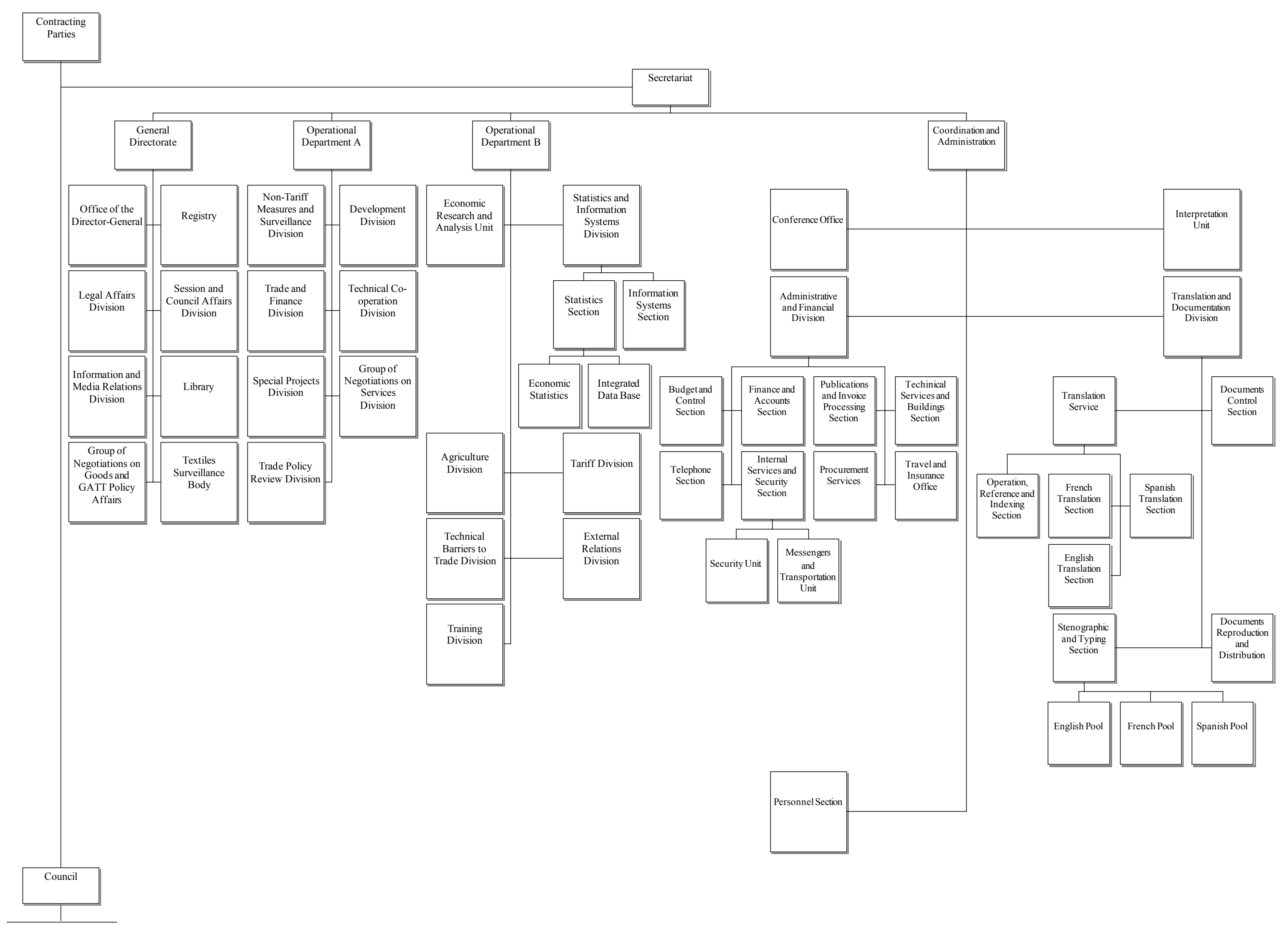


1991

Contracting
Parties

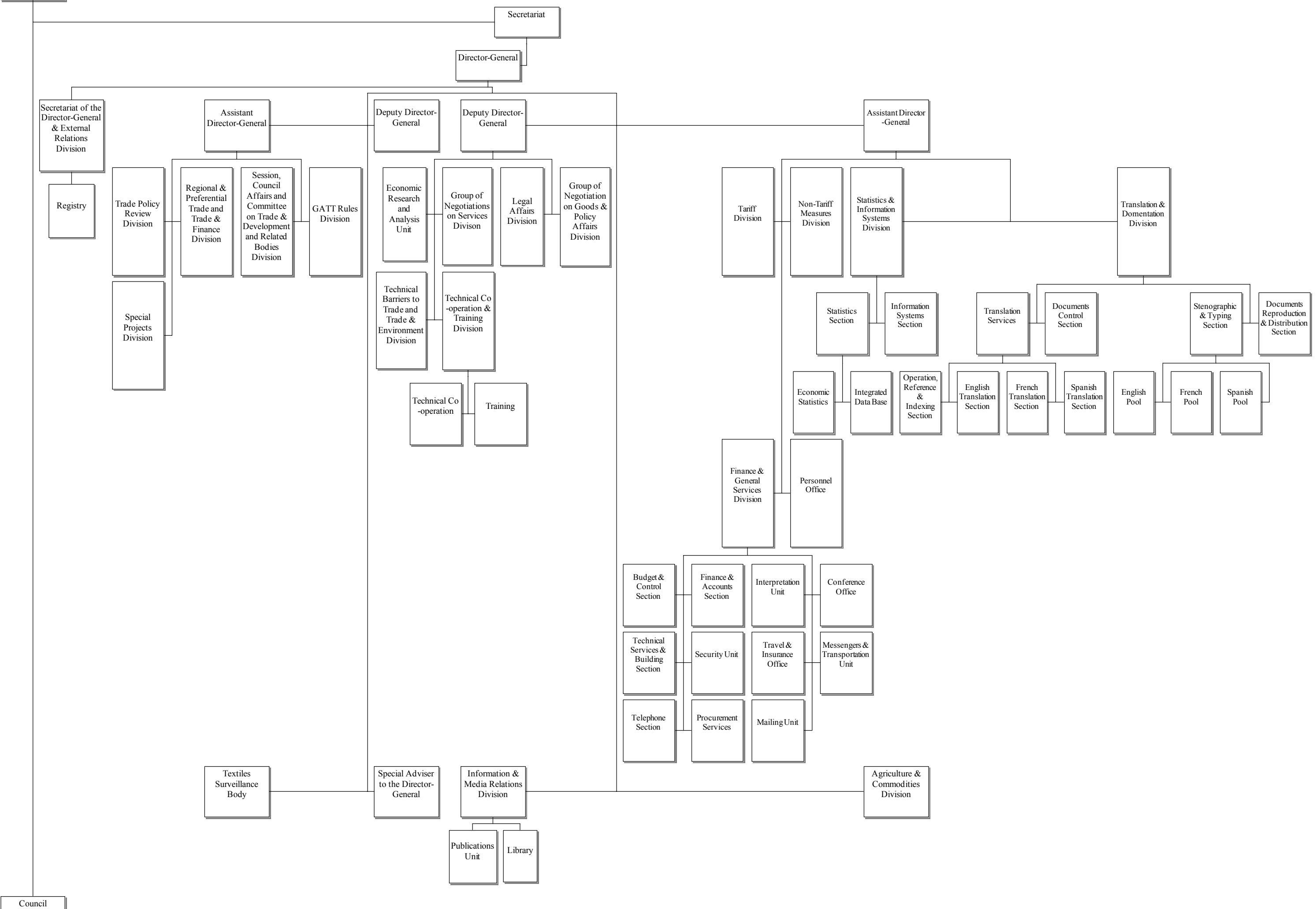


1993

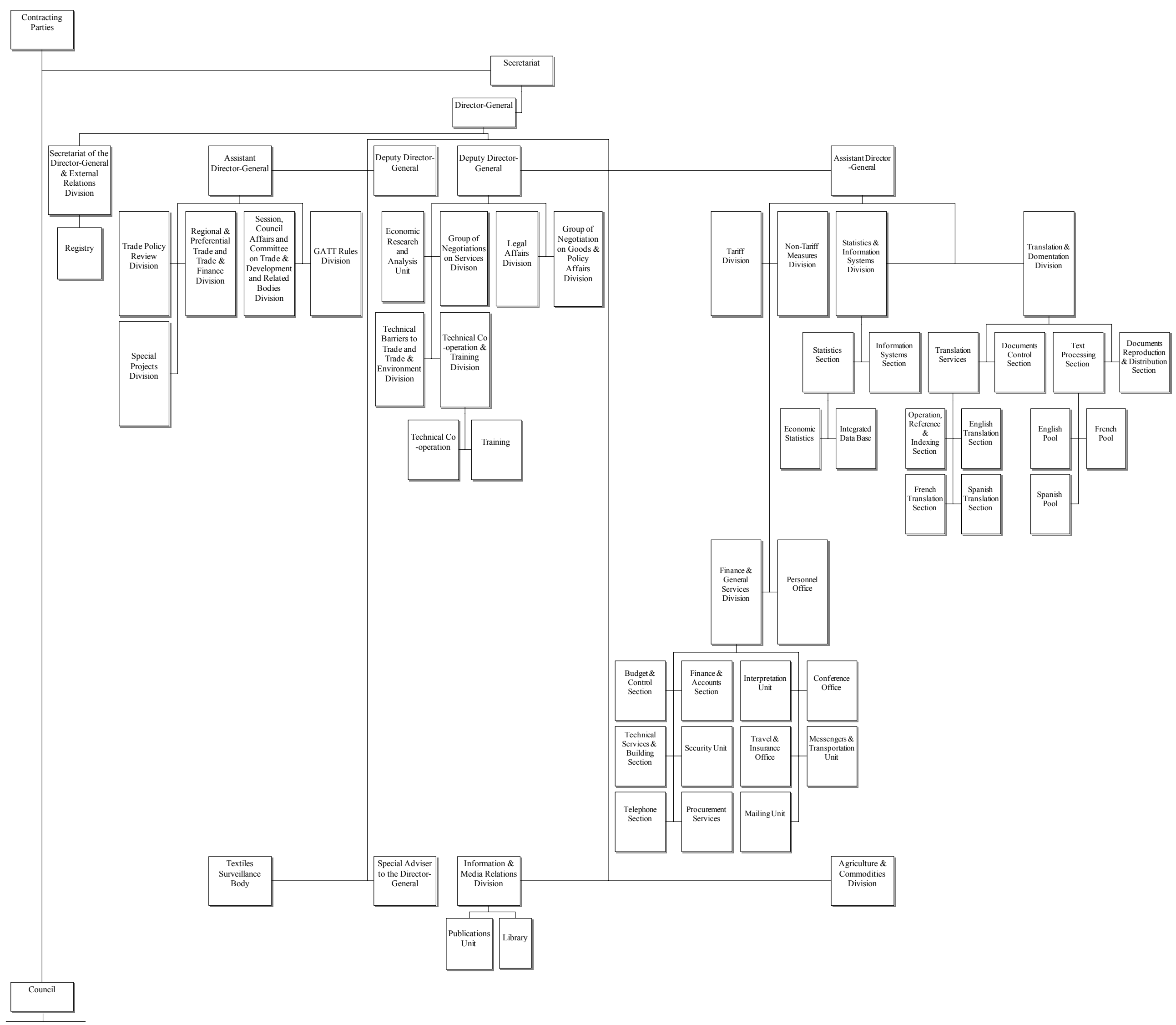




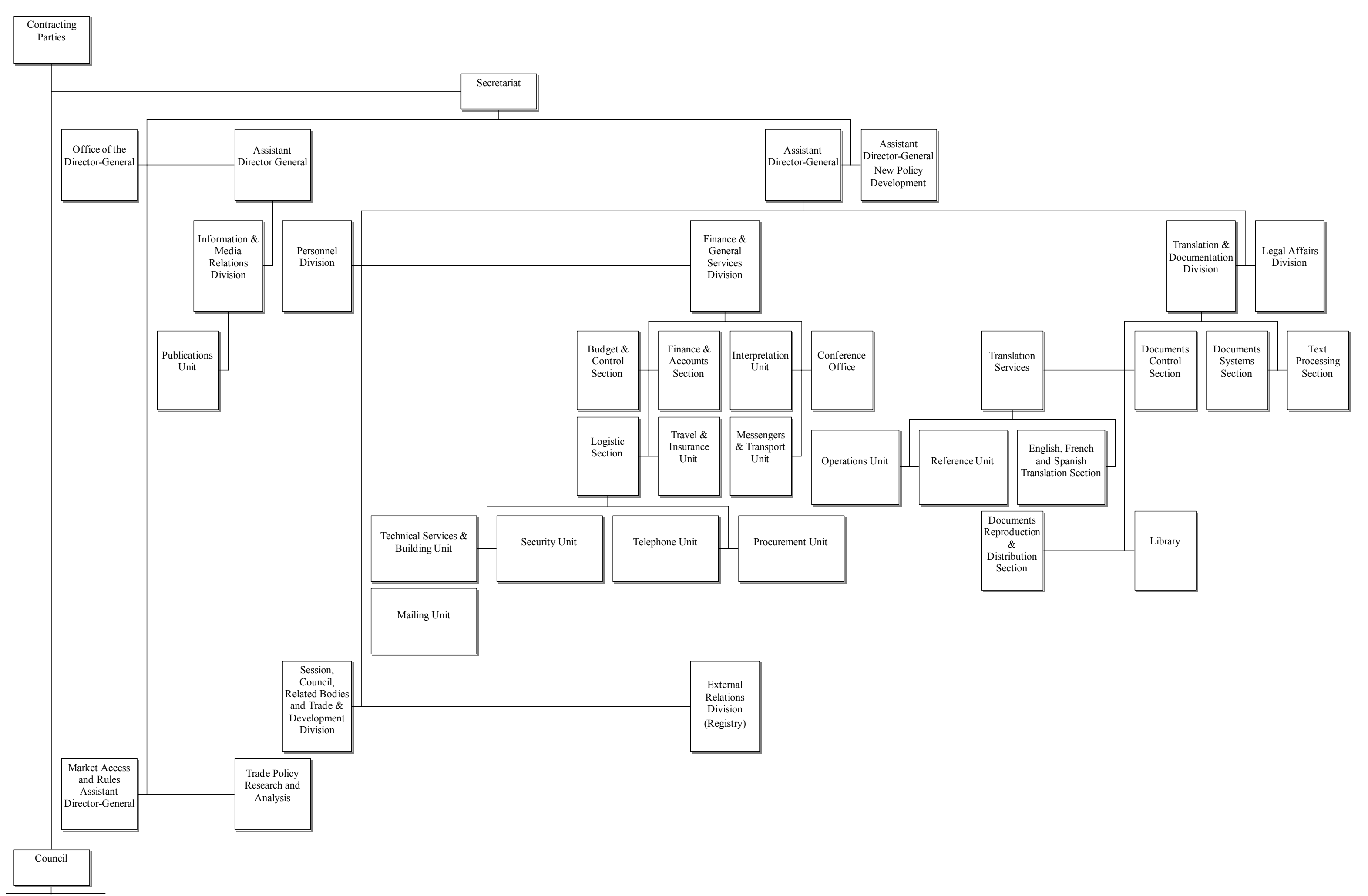




\section{APÊNDICE B - ORGANOGRAMA DA OMC (1995-2005)}

A seguir, são apresentados os organogramas relativos à estrutura da OMC nos seguintes períodos: (i) de 1995 (quando entrou em vigor) até 2001 (ano em que foi lançada a Rodada Doha); e (ii) de 2002 a 2005 (durante a Rodada Doha).

Observa-se que alguns dos órgãos previstos no primeiro organograma foram criados apenas depois de 1995. Adotou-se o organograma único para o período, contudo, em razão da previsão de seu estabelecimento.

Os organogramas foram elaborados com base nos seguintes documentos: OMC (WT/MIN(01)/DEC/1); OMC (TN/C/1); a descrição da estrutura do Secretariado, disponível em: <http://www.wto.org/english/thewto_e/whatis_e/tif_e/org4_e.htm>; e o organograma da $\mathrm{OMC}$ de 2006, disponível em: $<$ http://www.wto.org/english/thewto_e/whatis_e/tif_e/org2_e.htm>.

Os nomes em português foram retirados do Decreto n. 313, de 30 de julho de 1948, que incorpora a ata final dos resultados da Rodada Uruguai ao ordenamento brasileiro. 


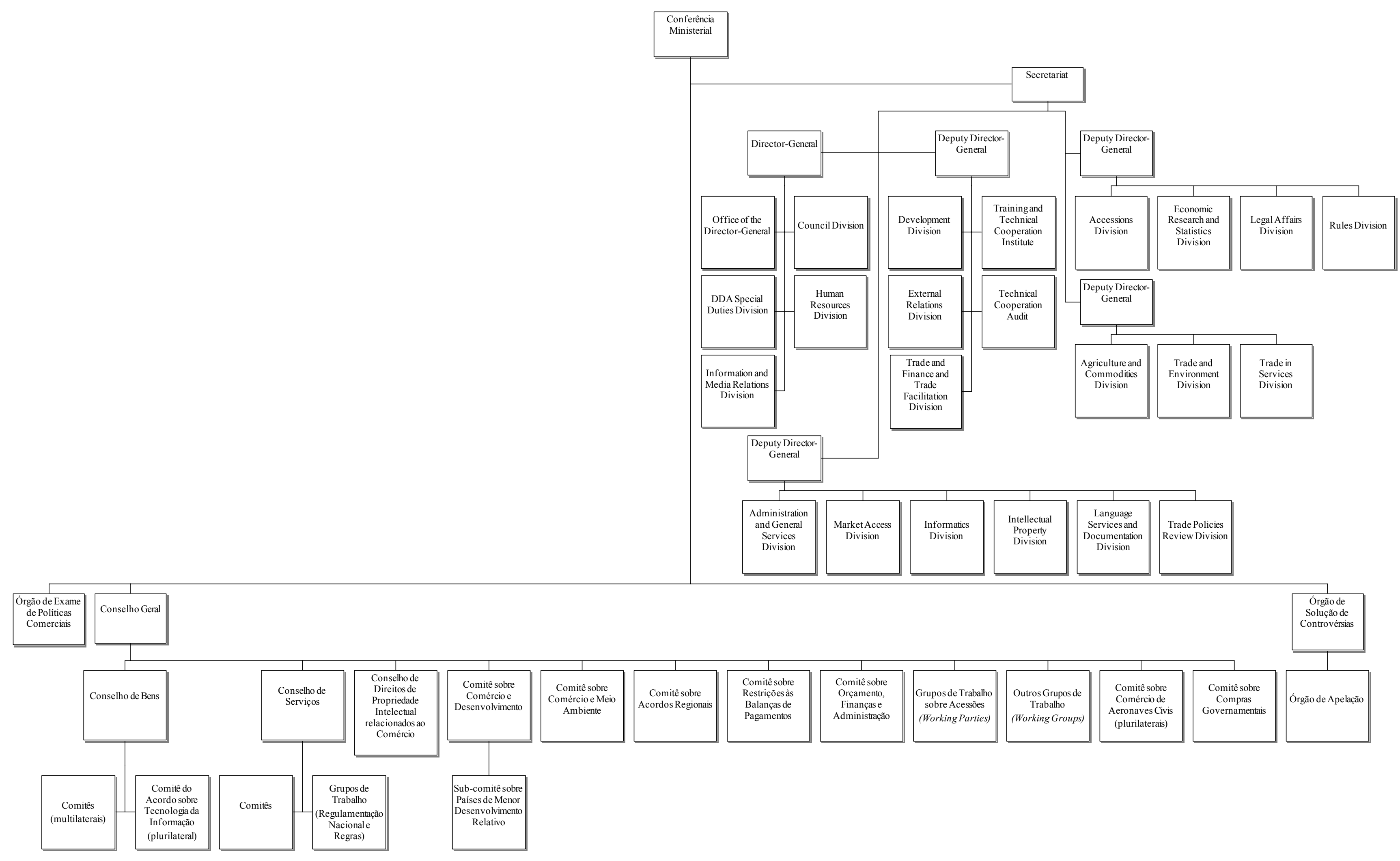




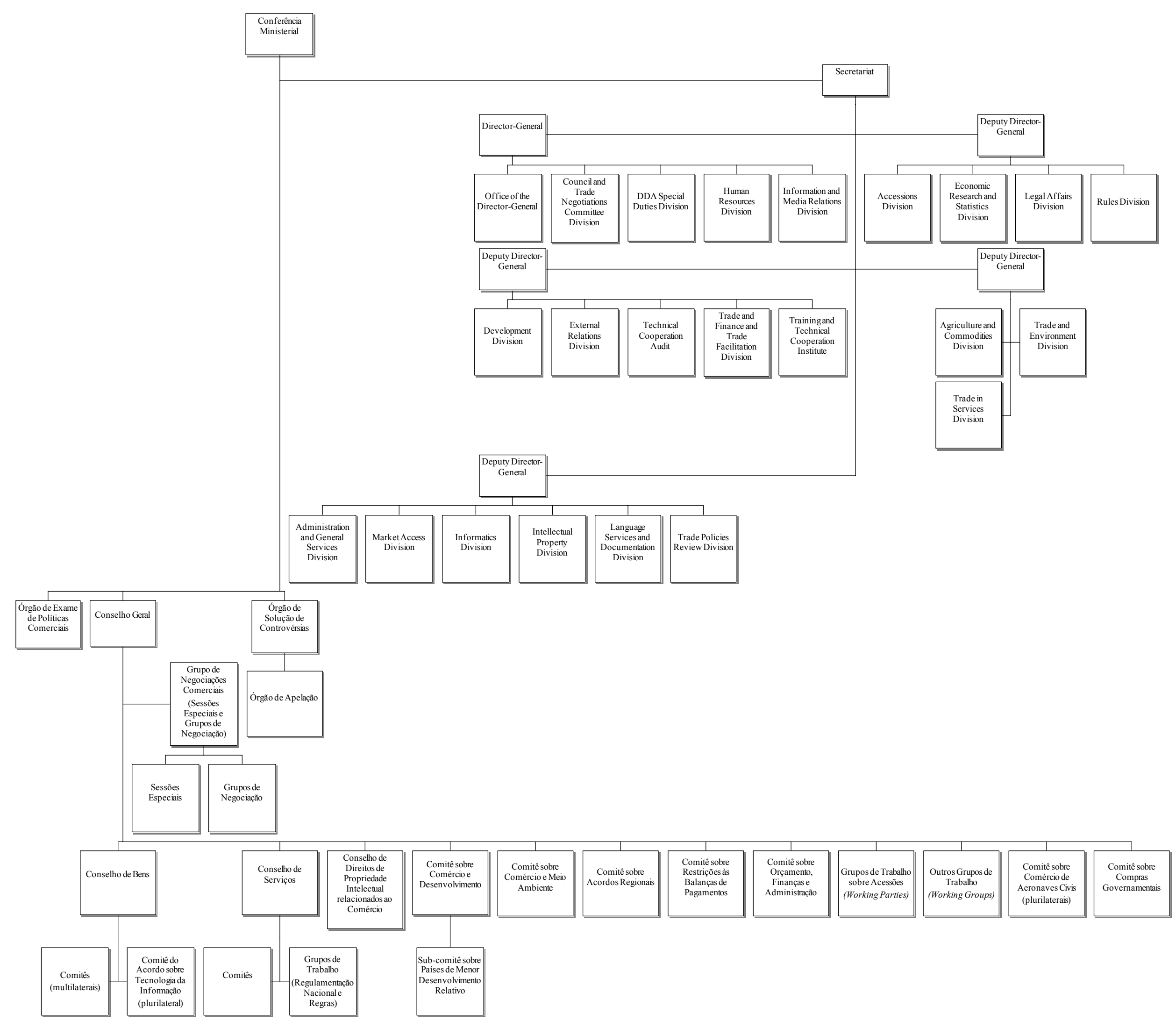




\section{APÊNDICE C - DADOS RELATIVOS ÀS DISPUTAS ANALISADAS}

\section{EUA - Atum}

Título Oficial

United States - Prohibition of Imports of Tuna and Tuna Products from Canada

Demandante

Canadá

Demandado

EUA

Terceiras Partes

$-\mathrm{X}-$

Painelistas

P. K. Williams

T. H. Chan

J.-D. Gerber

Documentos

Pedido de estabelecimento de painel: GATT (L/4931)

Relatório do painel: GATT (L/5198)

Cronologia

Pedido de estabelecimento de painel

21 de janeiro de 1980

Presença na agenda do Conselho

29 de janeiro de 1980

Estabelecimento do painel, 26 de março de 1980 elaboração dos termos de referência e autorização para o presidente do Conselho indicar os painelistas em consulta com as partes

Apresentação do relatório do painel 22 de dezembro de 1981 Adoção do relatório do painel 22 de fevereiro de 1982 


\section{Canadá - Arenque e Salmão}

Título Oficial

Canada - Measures Affecting Exports of Unprocessed Herring and Salmon

Demandante EUA

Demandado Canadá

Terceiras Partes - -

Painelistas

János Nyerges

Timothy Groser

Arne Sivertsen

Documentos

Pedido de estabelecimento de painel: GATT (L/6132)

Relatório do painel: GATT (L/6268)

Cronologia Realização das consultas

3 de setembro e 27 de outubro de 1986

Pedido de estabelecimento de

20 de fevereiro de 1987

painel

Aprovação do pedido de

4 de março de 1987

estabelecimento de painel

Elaboração dos termos de

15 de abril de 1987

referência e comunicação da

composição do painel

Audiências com as partes

18 de junho e 10 de julho de 1987

Apresentação do relatório do painel 4 de novembro de 1987 para as partes da controvérsia

Divulgação do relatório

20 de novembro de 1987

Adoção do relatório

22 de março de 1988

\section{EUA - Automóveis}


Demandante

Demandado

Terceiras Partes

Painelistas

Documentos

Cronologia
$\mathrm{CE}$

EUA

Austrália, Japão e Suécia

Thomas Cottier (presidente)

Carlos M. Cozendey

Adrian Macey

Pedido de estabelecimento de painel: GATT (DS31/2)

Relatório do painel: GATT (DS31/R)

Pedido de consultas

20 de maio de 1992

Realização das consultas

15 de julho e 20 de setembro de 1992

Pedido de estabelecimento do painel

Autorização do Conselho para estabelecimento de painel

Solicitação de participação como terceira parte

Composição do painel e elaboração dos termos de referência

Audiências com as partes

Audiência com terceiras partes

Apresentação do relatório do painel
12 de março de 1993

12 de maio de 1993

12 de maio de 1993

2 de agosto de 1993

4-5 de novembro e 16-17 de dezembro de 1993

4-5 de novembro de 1993

30 de setembro de 1994

\section{EUA - Gasolina}

Título Oficial

United States - Standards for Reformulated and Conventional Gasoline (DS 2-4)

Demandantes

Venezuela e Brasil

Demandado

EUA 
Terceiras Partes

Painelistas

Divisão do Órgão de Apelação

Documentos

Cronologia
Austrália, Canadá, CE e Noruega

Joseph Wong (presidente)

Crawford Falconer

Kim Luotonen

Florentino Feliciano

Christopher Beeby

Mitsuo Matsushita

Pedido de estabelecimento de painel: WTO (WT/DS2/2)

Relatório do painel: WTO (WT/DS2/R)

Relatório do Órgão de Apelação: WTO (WT/DS2/AB/R)

Comunicação da aprovação dos relatórios: WTO (WT/DS2/9)

Minuta da reunião em que se discutiu a aprovação dos relatórios: WTO (WT/DS/M/17)

Pedido de consultas - Venezuela

24 de janeiro de 1995

Realização de consultas com

Venezuela

24 de fevereiro de 1995

Pedido de estabelecimento de painel - Venezuela

Estabelecimento de painel -

10 de abril de 1995

Venezuela e pedido de consultas Brasil

Realização de consultas - Brasil

$1^{\circ}$ de maio de 1995

Pedido de estabelecimento de painel - Brasil

Estabelecimento de painel - Brasil e consolidação dos dois procedimentos em procedimento único

Audiências com as partes

Audiência com as terceiras partes

Pedido de extensão do prazo para apresentação do relatório do painel
10-12 de julho e 15 de setembro de 1995

11 de julho de 1995

19 de maio de 1995

31 de maio de 1995

21 de setembro de 1995 
Apresentação do relatório preliminar do painel

Apresentação do relatório final do painel

Notificação da apelação

Apelação

Contrarrazões dos apelados e das terceiras partes

Audiências com as partes e terceiras partes

Apresentação do relatório do Órgão 29 de abril de 1996 de Apelação

Aprovação dos relatórios
11 de dezembro de 1995

17 de janeiro de 1996

21 de fevereiro de 1996

4 de março de 1996

18 de março de 1996

27-28 de março de 1996

20 de maio de 1996

\section{EUA - Camarões}

Título Oficial

Demandante

Demandado

Terceiras Partes

Painelistas

de Apelação

Documentos
United States - Import Prohibition of Certain Shrimp and Shrimp Products (DS58)

Índia, Malásia, Paquistão e Tailândia

EUA

Austrália, CE, Cingapura, Colômbia, Costa Rica, Equador, El Salvador, Filipinas, Guatemala, Hong Kong, Japão, México, Nigéria, Senegal, Sri Lanka e Venezuela

Michael Cartland

Carlos Cozendey

Kilian Delbrück

Florentino Feliciano

James Bacchus

Julio Lacarte-Muró

Pedidos de estabelecimento de painel: WTO (/DS58/6), WTO (WT/DS58/7), WTO (WT/DS58/8)

Relatório do painel: WTO (WT/DS58/R) 
Relatório do Órgão de Apelação: WTO (WT/DS58/AB/R)

Comunicação da aprovação dos relatórios: WTO (WT/DS58/14)

Minuta da reunião em que se discutiu a aprovação dos relatórios: WTO (WT/DS/M/50).

Cronologia

Pedido de consultas

8 de outubro de 1996

Pedido de estabelecimento de

9 de janeiro de 1997

painel - Malásia e Tailândia

Pedido de estabelecimento de

30 de janeiro de 1997

painel - Paquistão

Estabelecimento dos painéis

requeridos e pedido de

estabelecimento de painel - Índia

Estabelecimento de painel - Índia, consolidação dos procedimento em

10 de abril de 1997 um único e elaboração dos termos de referência

Composição do painel

15 de abril de 1997

Audiências com as partes

17-19 de junho e 15-16 de setembro de 1997

Audiências com as terceiras partes

19 de junho de 1997

Pedido de extensão do prazo para

22 de setembro de 1997 apresentação do relatório do painel

Reunião com especialistas

21-22 de janeiro de 1998

Apresentação do relatório

2 de março de 1998

preliminar do painel

Apresentação do relatório final do painel

Notificação da apelação

13 de julho de 1998

Apresentação da apelação

23 de julho de 1998

Contrarrazões dos apelados e das terceiras partes

7 de agosto de 1998

Manifestação adicional sobre o

17 de agosto de 1998 artigo XX do GATT-1994

Audiência com as partes e terceiras 
partes

Apresentação do relatório do Órgão 12 de outubro de 1998 de Apelação

Aprovação dos relatórios

6 de novembro de 1998 


\section{APÊNDICE D - TERMOS DE REFERÊNCIA E MOTIVAÇÃO PARA ESTABELECIMENTO DE PAINEL NAS DISPUTAS ANALISADAS}

\section{Disputa}

EUA - Atum do Canadá
Canadá - Arenque e Salmão
To examine, in the light of the relevant GATT provisions, the matter referred to the CONTRACTING PARTIES by the United States relating to Canada's measures affecting exports of unprocessed herring and salmon (L/6132), and to make such findings as will assist the CONTRACTING PARTIES in making recommendations or rulings as provided for in paragraph 2 of
Le 31 aout 1979, le gouvernement des Etats-Unis a interdit les importations de thon et de produits du thon en provenance du Canada. Cette mesure discriminatoire prise a l'encontre du Canada est de toute evidence contraire aux obligations contractses par les Etats-Unis aux termes de l'Accord général, et les avantages resultant pour le Canada dudit accord ont été et se trouvent encore compromis. ${ }^{175}$

The United States considers that this prohibition contravenes Canada's obligations under the General Agreement, particularly the provisions of Article XI, and it nullifies or impairs benefits accruing to the United States. ${ }^{17}$ 
Article XXIII. ${ }^{176}$

EUA - Automóveis

EUA - Gasolina
To examine, in the light of the relevant GATT provisions, the matter referred to the CONTRACTING PARTIES by the European Economic Community in document DS31/2 and to make such findings as will assist the CONTRACTING PARTIES in making the recommendations or in giving the rulings provided for in Article XXIII:2. ${ }^{178}$

To examine, in the light of the relevant provisions of the covered agreements cited by Venezuela in document WT/DS2/2 and by Brazil in document WT/DS4/2, the matters referred to the DSB by Venezuela and Brazil in those documents and to make such findings as will assist the DSB in making the recommendations or in giving the rulings provided for in those agreements. ${ }^{180}$
The Community therefore requests the CONTRACTING PARTIES to establish a panel under Article XXIII:2 of the GATT in order to consider the question whether the US gasguzzler and luxury taxes and the Corporate Average Fuel Efficiency payments and their incidence on imported cars, in particular cars imported from the European Community, are contrary to Articles III: 1 and III:2 of the GATT, severally and jointly. ${ }^{179}$

The panel will have to examine the consistency of the Gasoline Regulation with Articles III and I of the General Agreement on Tariffs and Trade 1994 and Article 2 of the Agreement on Technical Barriers to Trade and any other relevant provision of the latter agreement. It must also examine the nullification and impairment of the benefits accruing to Venezuela under the WTO Agreement and any other implication of the Gasoline Regulation for Venezuela's gasoline exports to the United States. ${ }^{181}$

\footnotetext{
${ }^{176}$ GATT (L/6268:§1.3).

${ }^{177}$ GATT (L/6132:1).

${ }^{178}$ GATT (DS31/R:§1.3).

${ }^{179}$ GATT (DS31/2 :2).

${ }^{180}$ WTO (WT/DS2/2:§1.4).

${ }^{181}$ WTO (WT/DS2/2:2)
} 
Disputa

EUA - Camarões
Fundamentação
To examine, in the light of the relevant provisions of the covered agreements cited by Malaysia and Thailand in document WT/DS58/6, Pakistan in document WT/DS58/7 and India in document WT/DS58/8, the matter referred to the DSB by Malaysia, Thailand, Pakistan and India in these documents and to make such findings as will assist the DSB in making the recommendations or in giving the rulings provided for in those agreements. $^{182}$
Specifically, the embargo is inconsistent with at least the following three GATT obligations: (1) the proviso contained in Article XI:1 that no contracting party will impose prohibitions or restrictions on imports through quotas, licenses or other measures; (2) the mostfavoured-nation principle embodied in Article I:1; and (3) the proviso contained in Article XIII:1 that all allowable prohibitions or restrictions on imports must be applied in a nondiscriminatory manner. ${ }^{183}$

\footnotetext{
${ }^{182}$ WTO (WT/DS58:§1.4).

${ }^{183}$ WTO (WT/DS58/6:1); WTO (WT/DS58/7:1); WTO (WT/DS58/8:1).
} 


\title{
ANEXO A - DISPOSITIVOS DA CARTA DA OIC RELATIVOS À SOLUÇÃO DE CONTROVÉRSIAS
}

\section{Final Act o The United Nations Conference onTrade and Employment: Havana Charter for an International Trade Organization}

\author{
CHAPTER VIII: SETTLEMENT OF DIFFERENCES
}

\section{Article 92: Reliance on the Procedures of the Charter}

1. The Members undertake that they will not have recourse, in relation to other Members and to the Organization, to any procedure other than the procedures envisaged in this Charter for complaints and the settlement of differences arising out of its operation.

2. The Members also undertake, without prejudice to any other international agreement, that they will not have recourse to unilateral economic measures of any kind contrary to the provisions of this Charter.

\section{Article 93: Consultation and Arbitration}

1. If any Member considers that any benefit accruing to it directly or indirectly, implicitly or explicitly, under any of the provisions of this Charter other than Article 1, is being nullified or impaired as a result of

(a) a breach by a Member of an obligation under this Charter by action or failure to act, or

(b) the application by a Member of a measure not conflicting with the provisions of this harter, or

(c) the existence of any other situation the Member may, with a view to the satisfactory adjustment of the matter, make written representations or proposals to such other Member or Members as it considers to be concerned, and the Members receiving them shall give sympathetic consideration thereto.

2. The Members concerned may submit the matter arising under paragraph 1 to arbitration upon terms agreed between them; Provided that the decision of the arbitrator shall not be binding for any purpose upon the Organization or upon any Member other than the Members participating in the arbitration.

3. The Members concerned shall inform the Organization generally of the progress and outcome of any discussion, consultation or arbitration undertaken under this Charter. 
1. Any matter arising under sub-paragraphs (a) or (b) of paragraph 1 of Article 93 which is not satisfactorily settled and any matter which arises under paragraph 1 (c) of Article 93 may be referred by any Member concerned to the Executive Board.

2. The Executive Board shall promptly investigate the matter and shall decide whether any nullification or impairment within the terms of paragraph 1 of Article 93 in fact exists. It shall then take such of the following steps as may be appropriate:

(a) decide that the matter does not call for any action;

(b) recommend further consultation to the Members concerned;

(c) refer the matter to arbitration upon such terms as may be agreed between the Executive Board and the Members concerned;

(d) in any matter arising under paragraph 1 (a) of Article 93, request the Member concerned to take such action as may be necessary for the Member to conform to the provisions of this Charter;

(e) in any matter arising under sub-paragraph (b) or (c) of paragraph 1 of Article 93, make such recommendations to Members as will best assist the Members concerned and contribute to a satisfactory adjustment.

3. If the Executive Board considers that action under sub-paragraphs (d) and (e) of paragraph 2 is not likely to be effective in time to prevent serious injury, and that any nullification or impairment found to exist within the terms of paragraph 1 of Article 93 is sufficiently serious to justify such action, it may, subject to the provisions of paragraph 1 of Article 95, release the Member or Members affected from obligations or the grant of concessions to any other Member or Members under or pursuant to this Charter, to the extent and upon such conditions as it considers appropriate and compensatory, having regard to the benefit which has been nullified or impaired.

4. The Executive Board may, in the course of its investigation, consult with such Members or inter-governmental organizations upon such matters within the scope of this Charter as it deems appropriate. It may also consult any appropriate commission of the Organization on any matter arising under this Chapter.

5. The Executive Board may bring any matter, referred to it under this Article, before the Conference at any time during its consideration of the matter.

\section{Article 95: Reference to the Conference}

1. The Executive Board shall, if requested to do so within thirty days by a Member concerned, refer to the Conference to review any action, decision or recommendation by the Executive Board under paragraphs 2 or 3 of Article 94. Unless such review has been asked for by a Member concerned, Members shall be entitled to act in accordance with any action, decision or recommendation of the Executive Board under paragraphs 2 or 3 of Article 94. The Conference shall confirm, modify or reverse such action, decision or recommendation referred to it under this paragraph.

2. Where a matter arising under this Chapter has been brought before the Conference by the Executive Board, the Conference shall follow the procedure set out in paragraph 2 of Article 94 for the Executive Board.

3. If the Conference considers that any, nullification or impairment found to exist within the terms of paragraph 1 (a) of Article 93 is sufficiently serious to justify such action, it 
may release the Member or Members affected from obligations or the grant of concessions to any other Member or Members under or pursuant to this Charter, to the extent and upon such conditions as it considers appropriate and compensatory, having regard to the benefit which has been nullified or impaired. If the Conference considers that any nullification or impairment found to exist within the terms of sub-paragraphs (b) or (c) of paragraph 1 of Article 93 is sufficiently serious to justify such action, it may similarly release a Member or Members to the extent and upon such conditions as will best assist the Members concerned and contribute to a satisfactory adjustment.

4. When any Member or Members, in accordance with the provisions of paragraph 3, suspend the performance of any obligation or the grant of any concession to another Member, the latter Member shall be free, not later than sixty days after such action is taken, or if an opinion has been requested from the International Court of Justice pursuant to the provisions of Article 96, after such opinion has been delivered, to give written notice of its withdrawal from the Organization. Such withdrawal shall become effective upon the expiration of sixty days from the day on which such notice is received by the DirectorGeneral.

\section{Article 96: Reference to the International Court of Justice}

1. The Organization may, in accordance with arrangements made pursuant to paragraph 2 of Article 96 of the Charter of the United Nations, request from the International Court of Justice advisory opinions on legal questions arising within the scope of the activities of the Organization.

2. Any decision of the Conference under this Charter shall, at the instance of any Member whose interests are prejudiced by the decision, be subject to review by the International Court of Justice by means of a request, in appropriate form, for an advisory opinion pursuant to the Statute of the Court.

3. The request for an opinion shall be accompanied by a statement of the question upon which the opinion is required and by all documents likely to throw light upon the question. This statement shall be furnished by the Organization in accordance with the Statute of the Court and after consultation with the Members substantially interested.

4. Pending the delivery of the opinion of the Court, the decision of the Conference shall have full force and effect; Provided that the Conference shall suspend the operation of any such decision pending the delivery of the opinion where, in the view of the Conference, damage difficult to repair would otherwise be caused to a Member concerned.

5. The Organization shall consider itself bound by the opinion of the Court on any question referred by it to the Court. In so far as it does not accord with the opinion of the Court, the decision in question shall be modified.

\section{Article 97: Miscellaneous Provisions}

1. Nothing in this Chapter shall be construed to exclude other procedures provided for in this Charter for consultation and the settlement of differences arising out of its operation. The Organization may regard discussion, consultation or investigation undertaken under any other provisions of this Charter as fulfilling, either in whole or in part, any similar procedural requirement in this Chapter. 
2. The Conference and the Executive Board shall establish such rules of procedure as may be necessary to carry out the provisions of this Chapter. 


\section{ANEXO B - REDAÇÃO ORIGINAL DOS ARTIGOS XXII E XXIII DO} GATT-1947

\section{ARTIGO XXII}

\section{CONSULTAS}

Cada Parte Contratante examinará, com espírito de compreensão, as representações que qualquer outra Parte Contratante possa fazer e facilitará, na medida do possível, as consultas relativas a essas representações, quando estas se referirem à aplicação dos regulamentos e formalidades de alfândega, às taxas anti-dumping e aos direitos de compensação, às regulamentações quantitativas e de câmbio, às subvenções, às operações do comércio do Estado, às prescrições sanitárias e aos regulamentos relativos à proteção da saúde e da vida das pessoas e dos animais e à preservação dos vegetais e, de maneira geral, sôbre tôdas as questões relativas à aplicação das disposições do presente Acôrdo.

\section{ARTIGO XXIII}

\section{PROTEÇÃO DE CONCESSÕES E VANTAGENS}

1. No caso de uma Parte Contratante considerar que uma vantagem qualquer resultante para ela, direta ou indiretamente, do presente Acôrdo, está sendo anulada ou reduzida, ou que um dos objetivos do Acôrdo está sendo dificultado, em conseqüência:

a) do não cumprimento por outra das Partes Contratantes dos compromissos pela mesma assumidos em virtude do presente Acôrdo;

b) da aplicação por outra das Partes Contratantes de uma medida, contrária ou não às disposições do presente Acôrdo; ou

c) da existência de qualquer outra situação, dita Parte Contratante, a fim de obter solução satisfatória para a questão, poderá dirigir representações ou propostas por escrito à outra ou outras Partes Contratantes que lhe parecerem interessadas. Qualquer Parte Contratante, por essa forma interpelada, examinará, com boa vontade, as representações ou propostas que lhe tenham sido dirigidas.

2. Se as Partes Contratantes interessadas não chegarem a um Acôrdo satisfatório dentro de um prazo razoável, ou se a dificuldade fôr uma das previstas no $\S 1$ (c) dêste artigo, a questão poderá ser submetida às Partes Contratantes. As Partes Contratantes iniciarão, sem demora, uma investigação sôbre qualquer assunto que lhes seja submetido e, se julgarem 
conveniente, dirigirão recomendações especiais e apropriadas às partes Contratantes que julguem interessadas, ou baixarão normas sôbre a questão. As Partes Contratantes, quando acharem necessário, poderão efetuar consultas com as outras Partes Contratantes, com o Conselho Econômico e Social das Nações Unidas e com qualquer outra organização intergovernamental competente. Se as Partes Contratantes acharem que as circunstâncias são suficientemente graves para justificar tal medida, poderão autorizar a uma ou a váriás Partes Contratantes a suspensão, relativamente a tal ou a tais Partes Contratantes, da aplicação de qualquer obrigação ou concessão resultante do presente Acôrdo. Se, a observância de uma obrigação ou o benefício de uma concessão em favor de uma Parte Contratante fôr suspenso efetivamente, essa Parte Contratante poderá dentro de um prazo de sessenta dias a contar da data da aplicação da medida, notificar o Secretário Geral das Nações Unidas por escrito, de sua intenção de denunciar êste Acôrdo e tal denúncia terá efeito, expirado o prazo de sessenta dias a contar da data em que o Secretário Geral das Nações Unidas receba notificação escrita da denúncia. 


\section{ANEXO C - DECISÃO DE 1966}

\section{DECISION OF 5 APRIL 1966 ON PROCEDURES UNDER ARTICLE XXIII}

\section{(14S/18)}

\section{The CONTRACTING PARTIES,}

Recognizing that the prompt settlement of situations in which a contracting party considers that any benefits accruing to it directly or indirectly from the General Agreement are being impaired by measures taken by another contracting party, is essential to the effective functioning of the General Agreement and the maintenance of a proper balance between the rights and obligations of all contracting parties;

Recognizing further that the existence of such a situation can cause severe damage to the trade and economic development of the less-developed contracting parties; and

Affirming their resolve to facilitate the solution of such situations while taking fully into account the need for safeguarding both the present and potential trade of less-developed contracting parties affected by such measures;

Decide that:

1. If consultations between a less-developed contracting party and a developed contracting party in regard to any matter falling under paragraph 1 of Article XXIII do not lead to a satisfactory settlement, the lessdeveloped contracting party complaining of the measures may refer the matter which is the subject of consultations to the Director-General so that, acting in an ex officio capacity, he may use his good offices with a view to facilitating a solution.

2. To this effect the contracting parties concerned shall, at the request of the DirectorGeneral, promptly furnish all relevant information.

3. On receipt of this information, the Director-General shall consult with the contracting parties concerned and with such other contracting parties or inter-governmental organizations as he considers appropriate with a view to promoting a mutually acceptable solution.

4. After a period of two months from the commencement of the consultations referred to in paragraph 3 above, if no mutually satisfactory solution has been reached, the DirectorGeneral shall, at the request of one of the contracting parties concerned, bring the matter to the attention of the CONTRACTING PARTIES or the Council, to whom he shall submit a report on the action taken by him, together with all background information.

5. Upon receipt of the report, the CONTRACTING PARTIES or the Council shall forthwith appoint a panel of experts to examine the matter with a view to recommending appropriate solution. The members of the panel shall act on a personal capacity and shall be appointed in consultation with, and with the approval of, the contracting parties concerned.

6. In conducting its examination and having before it all the background information, the panel shall take due account of all the circumstances and considerations relating to the application of the measures complained of, and their impact on the trade and economic development of affected contracting parties. 
7. The panel shall, within a period of sixty days from the date the matter was referred to it, submit its findings and recommendations to the CONTRACTING PARTIES or to the Council, for consideration and decision. Where the matter is referred to the Council, it may, in accordance with Rule 8 of the Intersessional Procedures adopted by the CONTRACTING PARTIES at their thirteenth session ${ }^{1}$, address its recommendations directly to the interested contracting parties and concurrently report to the CONTRACTING PARTIES.

8. Within a period of ninety days from the date of the decision of the CONTRACTING PARTIES, or the Council, the contracting party to which a recommendation is directed shall report to the CONTRACTING PARTIES or the Council on the action taken by it in pursuance of the decision.

9. If on examination of this report it is found that a contracting party to which a recommendation has been directed has not complied in full with the relevant recommendation of the CONTRACTING PARTIES or the Council, and that any benefit accruing directly or indirectly under the General Agreement continues in consequence to be nullified or impaired, and that the circumstances are serious enough to justify such action, the CONTRACTING PARTIES may authorize the affected contracting party or parties to suspend, in regard to the contracting party causing the damage, application of any concession or any other obligation under the General Agreement whose suspension is considered warranted, taking account of the circumstances.

10. In the event that a recommendation to a developed country by the CONTRACTING PARTIES is not applied within the time-limit prescribed in paragraph 8, the CONTRACTING PARTIES shall consider what measures, further to those undertaken under paragraph 9 , should be taken to resolve the matter.

11. If consultations, held under paragraph 2 of Article XXXVII, relate to restrictions for which there is no authority under any provisions to the General Agreement, any of the parties to the consultations may, in the absence of a satisfactory solution, request that consultations be carried out by the CONTRACTING PARTIES pursuant to paragraph 2 of Article XXIII and in accordance with the procedures set out in the present decision, is being understood that a consultation held under paragraph 2 of Article XXXVII in respect of such restrictions will be considered by the CONTRACTING PARTIES as fulfilling the conditions of paragraph 1 of Article XXIII if the parties to the consultations so agree.

$17 \mathrm{~S} / 7$. 


\section{ANEXO D - ENTENDIMENTO DE 1979}

\section{UNDERSTANDING REGARDING NOTIFICATION, CONSULTATION, DISPUTE SETTLEMENT AND SURVEILLANCE}

Adopted on 28 November 1979 (L/4907)

1. The CONTRACTING PARTIES reaffirm their adherence to the basic GATT mechanism for the management of disputes based on Articles XXII and XXIII. ${ }^{1}$ With a view to improving and refining the GATT mechanism, the CONTRACTING PARTIES agree as follows:

\section{Notification}

2. Contracting parties reaffirm their commitment to existing obligations under the General Agreement regarding publication and notification.

3. Contracting parties moreover undertake, to the maximum extent possible, to notify the CONTRACTING PARTIES of their adoption of trade measures affecting the operation of the General Agreement, it being understood that such notification would of itself be without prejudice to views on the consistency of measures with or their relevance to rights and obligations under the General Agreement. Contracting parties should endeavour to notify such measures in advance of implementation. In other cases, where prior notification has not been possible, such measures should be notified promptly ex post facto. Contracting parties which have reason to believe that such trade measures have been adopted by another contracting party may seek information on such measures bilaterally, from the contracting party concerned.

\section{Consultations}

4. Contracting parties reaffirm their resolve to strengthen and improve the effectiveness of consultative procedures employed by contracting parties. In that connection, they undertake to respond to requests for consultations promptly and to attempt to conclude consultations expeditiously, with a view to reaching mutually satisfactory conclusions. Any requests for consultations should include the reasons therefor.

5. During consultations, contracting parties should give special attention to the particular problems and interests of less-developed contracting parties.

6. Contracting parties should attempt to obtain satisfactory adjustment of the matter in accordance with the provisions of Article XXIII:1 before resorting to Article XXIII:2.

Dispute settlement

7. The CONTRACTING PARTIES agree that the customary practice of the GATT in the field of dispute settlement, described in the Annex, should be continued in the future, with the improvements set out below. They recognize that the efficient functioning of the 
system depends on their will to abide by the present understanding. The CONTRACTING PARTIES reaffirm that the customary practice includes the procedures for the settlement of disputes between developed and less-developed countries adopted by the CONTRACTING PARTIES in $1966^{2}$ and that these remain available to less-developed contracting parties wishing to use them.

8. If a dispute is not resolved through consultations the contracting parties concerned may request an appropriate body or individual to use their good offices with a view to the conciliation of the outstanding differences between the parties. If the unresolved dispute is one in which a less-developed contracting party has brought a complaint against a developed contracting party, the less-developed contracting party may request the good offices of the Director-General who, in carrying out his tasks, may consult with the Chairman of the CONTRACTING PARTIES and the Chairman of the Council.

9. It is understood that requests for conciliation and the use of the dispute settlement procedures of Article XXIII:2 should not be intended or considered as contentious acts and that, if disputes arise, all contracting parties will engage in these procedures in good faith in an effort to resolve the disputes. It is also understood that complaints and countercomplaints in regard to distinct matters should not be linked.

10. It is agreed that if a contracting party invoking Article XXIII:2 requests the establishment of a panel to assist the CONTRACTING PARTIES to deal with the matter, the CONTRACTING PARTIES would decide on its establishment in accordance with standing practice. It is also agreed that the CONTRACTING PARTIES would similarly decide to establish a working party if this were requested by a contracting party invoking the Article. It is further agreed that such requests would be granted only after the contracting party concerned had had an opportunity to study the complaint and respond to it before the CONTRACTING PARTIES.

11. When a panel is set up, the Director-General, after securing the agreement of the contracting parties concerned, should propose the composition of the panel, of three or five members depending on the case, to the CONTRACTING PARTIES for approval. The members of a panel would preferably be governmental. It is understood that citizens of countries whose governments ${ }^{3}$ are parties to the dispute would not be members of the panel concerned with that dispute. The panel should be constituted as promptly as possible and normally not later than thirty days from the decision by the CONTRACTING PARTIES.

12. The parties to the dispute would respond within a short period of time, i.e., seven working days, to nominations of panel members by the Director-General and would not oppose nominations except for compelling reasons.

13. In order to facilitate the constitution of panels, the Director-General should maintain an informal indicative list of governmental and non-governmental persons qualified in the fields of trade relations, economic development, and other matters covered by the General Agreement, and who could be available for serving on panels. For this purpose, each contracting party would be invited to indicate at the beginning of every year to the Director-General the name of one or two persons who would be available for such work. ${ }^{4}$

14. Panel members would serve in their individual capacities and not as government representatives, nor as representatives of any organization. Governments would therefore not give them instructions nor seek to influence them as individuals with regard to matters before a panel. Panel members should be selected with a view to ensuring the independence of the members, a sufficiently diverse background and wide spectrum of experience. ${ }^{5}$ 
15. Any contracting party having a substantial interest in the matter before a panel, and having notified this to the Council, should have an opportunity to be heard by the panel. Each panel should have the right to seek information and technical advice from any individual or body which it deems appropriate. However, before a panel seeks such information or advice from any individual or body within the jurisdiction of a State it shall inform the government of that State. Any contracting party should respond promptly and fully to any request by a panel for such information as the panel considers necessary and appropriate. Confidential information which is provided should not be revealed without formal authorization from the contracting party providing the information.

16. The function of panels is to assist the CONTRACTING PARTIES in discharging their responsibilities under Article XXIII:2. Accordingly, a panel should make an objective assessment of the matter before it, including an objective assessment of the facts of the case and the applicability of and conformity with the General Agreement and, if so requested by the CONTRACTING PARTIES, make such other findings as will assist the CONTRACTING PARTIES in making the recommendations or in giving the rulings provided for in Article XXIII:2. In this connection, panels should consult regularly with the parties to the dispute and give them adequate opportunity to develop a mutually satisfactory solution.

17. Where the parties have failed to develop a mutually satisfactory solution, the panel should submit its findings in a written form. The report of a panel should normally set out the rationale behind any findings and recommendations that it makes. Where a bilateral settlement of the matter has been found, the report of the panel may be confined to a brief description of the case and to reporting that a solution has been reached.

18. To encourage development of mutually satisfactory solutions between the parties and with a view to obtaining their comments, each panel should first submit the descriptive part of its report to the parties concerned, and should subsequently submit to the parties to the dispute its conclusions, or an outline thereof, a reasonable period of time before they are circulated to the CONTRACTING PARTIES.

19. If a mutually satisfactory solution is developed by the parties to a dispute before a panel, any contracting party with an interest in the matter has a right to enquire about and be given appropriate information about that solution in so far as it relates to trade matters.

20 . The time required by panels will vary with the particular case. ${ }^{6}$ However, panels should aim to deliver their findings without undue delay, taking into account the obligation of the CONTRACTING PARTIES to ensure prompt settlement. In cases of urgency the panel would be called upon to deliver its findings within a period normally of three months from the time the panel was established.

21. Reports of panels and working parties should be given prompt consideration by the CONTRACTING PARTIES. The CONTRACTING PARTIES should take appropriate action on reports of panels and working parties within a reasonable period of time. If the case is one brought by a less-developed contracting party, such action should be taken in a specially convened meeting, if necessary. In such cases, in considering what appropriate action might be taken the CONTRACTING PARTIES shall take into account not only the trade coverage of measures complained of, but also their impact on the economy of lessdeveloped contracting parties concerned.

22. The CONTRACTING PARTIES shall keep under surveillance any matter on which they have made recommendations or given rulings. If the CONTRACTING PARTIES' recommendations are not implemented within a reasonable period of time, the contracting 
party bringing the case may ask the CONTRACTING PARTIES to make suitable efforts with a view to finding an appropriate solution.

23. If the matter is one which has been raised by a less-developed contracting party, the CONTRACTING PARTIES shall consider what further action they might take which would be appropriate to the circumstances.

\section{Surveillance}

24. The CONTRACTING PARTIES agree to conduct a regular and systematic review of developments in the trading system. Particular attention would be paid to developments which affect rights and obligations under the GATT, to matters affecting the interests of less-developed contracting parties, to trade measures notified in accordance with this understanding and to measures which have been subject to consultation, conciliation or dispute settlement procedures laid down in this understanding.

\section{Technical assistance}

25. The technical assistance services of the GATT secretariat shall, at the request of a lessdeveloped contracting party, assist it in connection with matters dealt with in this understanding.

${ }^{I}$ It is noted that Article XXV may, as recognized by the CONTRACTING PARTIES, inter alia, when they adopted the report of the Working Party on particular difficulties connected with trade in primary products (L/930) also afford an appropriate avenue for consultation and dispute settlement in certain circumstances.

${ }^{2}$ BISD $14 S / 18$.

${ }^{3}$ In the case customs unions or common markets are parties to a dispute, this provision applies to citizens of all member countries of the customs unions or common markets.

${ }^{4}$ The coverage of travel expenses should be considered within the limits of budgetary possibilities.

${ }^{5}$ A statement is included in the Annex describing the current practice with respect to inclusion on panels of persons from developing countries.

${ }^{6}$ An explanation is included in the Annex that "in most cases the proceedings of the panels have been completed with a reasonable period of time, extending from three to nine months".

\section{ANNEX \\ Agreed Description of the Customary Practice of the GATT in the Field of Dispute Settlement (Article XXIII:2)}

1. Any dispute which has not been settled bilaterally under the relevant provisions of the General Agreement may be referred to the CONTRACTING PARTIES ${ }^{7}$ which are obliged, pursuant to Article XXIII:2, to investigate matters submitted to them and make appropriate recommendations or give a ruling on the matter as appropriate. Article XXIII:2 does not indicate whether disputes should be handled by a working party or by a panel. ${ }^{8}$ 
2. The CONTRACTING PARTIES adopted in 1966 a decision establishing the procedure to be followed for Article XXIII consultations between developed and less-developed contracting parties ${ }^{9}$. This procedure provides, inter alia, for the Director-General to employ his good offices with a view to facilitating a solution, for setting up a panel with the task of examining the problem in order to recommend appropriate solutions, and for time-limits for the execution of the different parts of this procedure.

3. The function of a panel has normally been to review the facts of a case and the applicability of GATT provisions and to arrive at an objective assessment of these matters. In this connection, panels have consulted regularly with the parties to the dispute and have given them adequate opportunity to develop a mutually satisfactory solution. Panels have taken appropriate account of the particular interests of developing countries. In cases of failure of the parties to reach a mutually satisfactory settlement, panels have normally given assistance to the CONTRACTING PARTIES in making recommendations or in giving rulings as envisaged in Article XXIII:2.

4. Before bringing a case, contracting parties have exercised their judgement as to whether action under Article XXIII:2 would be fruitful. Those cases which have come before the CONTRACTING PARTIES under this provision have, with few exceptions, been brought to a satisfactory conclusion. The aim of the CONTRACTING PARTIES has always been to secure a positive solution to a dispute. A solution mutually acceptable to the parties to a dispute is clearly to be preferred. In the absence of a mutually agreed solution, the first objective of the CONTRACTING PARTIES is usually to secure the withdrawal of the measures concerned if these are found to be inconsistent with the General Agreement. The provision of compensation should be resorted to only if the immediate withdrawal of the measure is impracticable and as a temporary measure pending the withdrawal of the measures which are inconsistent with the General Agreement. The last resort which Article XXIII provides to the country invoking this procedure is the possibility of suspending the application of concessions or other obligations on a discriminatory basis vis-à-vis the other contracting party, subject to authorization by the CONTRACTING PARTIES of such measures. Such action has only rarely been contemplated and cases taken under Article XXIII:2 have lead to such action in only one case.

5. In practice, contracting parties have had recourse to Article XXIII only when in their view a benefit accruing to them under the General Agreement was being nullified or impaired. In cases where there is an infringement of the obligations assumed under the General Agreement, the action is considered prima facie to constitute a case of nullification or impairment. A prima facie case of nullification or impairment would ipso facto require consideration of whether the circumstances are serious enough to justify the authorization of suspension of concessions or obligations, if the contracting party bringing the complaint so requests. This means that there is normally a presumption that a breach of the rules has an adverse impact on other contracting parties, and in such cases, it is up to the contracting parties against whom the complaint has been brought to rebut the charge. Paragraph 1 (b) permits recourse to Article XXIII if nullification or impairment results from measures taken by other contracting parties whether or not these conflict with the provisions of the General Agreement, and paragraph 1 (c) if any other situation exists. If a contracting party bringing an Article XXIII case claims that measures which do not conflict with the provisions of the General Agreement have nullified or impaired benefits accruing to it under the General Agreement, it would be called upon to provide a detailed justification.

6. Concerning the customary elements of the procedures regarding working parties and panels, the following elements have to be noted: 
(i) working parties are instituted by the Council upon the request of one or several contracting parties. The terms of reference of working parties are generally "to examine the matter in the light of the relevant provisions of the General Agreement and to report to the Council". Working parties set up their own working procedures. The practice for working parties has been to hold one or two meetings to examine the matter and a final meeting to discuss conclusions. Working parties are open to participation of any contracting party which has an interest in the matter. Generally working parties consist of a number of delegations varying from about five to twenty according to the importance of the question and the interests involved. The countries who are parties to the dispute are always members of the Working Party and have the same status as other delegations. The report of the Working Party represents the views of all its members and therefore records different views if necessary. Since the tendency is to strive for consensus, there is generally some measure of negotiation and compromise in the formulation of the Working Party's report. The Council adopts the report. The reports of working parties are advisory opinions on the basis of which the CONTRACTING PARTIES may take a final decision.

(ii) In the case of dispute, the CONTRACTING PARTIES have established panels (which have been called by different names) or working parties in order to assist them in examining questions raised under Article XXIII:2. Since 1952, panels have become the usual procedure. However, the Council has taken such decisions only after the party concerned has had an occasion to study the complaint and prepare its response before the Council. The terms of reference are discussed and approved by the Council. Normally, these terms of reference are "to examine the matter and to make such findings as will assist the CONTRACTING PARTIES in making the recommendations or rulings provided for in paragraph 2 of Article XXIII". When a contracting party having recourse to Article XXIII:2 raised questions relating to the suspension of concessions or other obligations, the terms of reference were to examine the matter in accordance with the provisions of Article XXIII:2. Members of the panel are usually selected from permanent delegations or, less frequently, from the national administrations in the capitals amongst delegates who participate in GATT activities on a regular basis. The practice has been to appoint a member or members from developing countries when a dispute is between a developing and a developed country.

(iii) Members of panels are expected to act impartially without instructions from their governments. In a few cases, in view of the nature and complexity of the matter, the parties concerned have agreed to designate non-government experts. Nominations are proposed to the parties concerned by the GATT secretariat. The composition of panels (three or five members depending on the case) has been agreed upon by the parties concerned and approved by the GATT Council. It is recognized that a broad spectrum of opinion has been beneficial in difficult cases, but that the number of panel members has sometimes delayed the composition of panels, and therefore the process of dispute settlement.

(iv) Panels set up their own working procedures. The practice for the panels has been to hold two or three formal meetings with the parties concerned. The panel invited the parties to present their views either in writing and/or orally in the presence of each other. The panel can question both parties on any matter which it considers relevant to the dispute. Panels have also heard the views of any contracting party having a substantial interest in the matter, which is not directly party to the dispute, but which has expressed in the Council a desire to present its views. Written memoranda submitted to the panel have been considered confidential, but are made available to the parties to the dispute. Panels often consult with and seek information from any relevant source they deem appropriate and they sometimes consult experts to obtain their technical opinion on certain aspects of the 
matter. Panels may seek advice or assistance from the secretariat in its capacity as guardian of the General Agreement, especially on historical or procedural aspects. The secretariat provides the secretary and technical services for panels.

(v) Where the parties have failed to develop a mutually satisfactory solution, the panel has submitted its findings in a written form. Panel reports have normally set out findings of fact, the applicability of relevant provisions, and the basic rationale behind any findings and

recommendations that it has made. Where a bilateral settlement of the matter has been found, the report of the panel has been confined to a brief description of the case and to reporting that a solution has been reached.

(vi) The reports of panels have been drafted in the absence of the parties in the light of the information and the statements made.

(vii) To encourage development of mutually satisfactory solutions between the parties and with a view to obtaining their comments, each panel has normally first submitted the descriptive part of its report to the parties concerned, and also their conclusions, or an outline thereof, a reasonable period of time before they have been circulated to the CONTRACTING PARTIES.

(viii) In accordance with their terms of reference established by the CONTRACTING PARTIES panels have expressed their views on whether an infringement of certain rules of the General Agreement arises out of the measure examined. Panels have also, if so requested by the CONTRACTING PARTIES, formulated draft recommendations addressed to the parties. In yet other cases panels were invited to give a technical opinion on some precise aspect of the matter (e.g. on the modalities of a withdrawal or suspension in regard to the volume of trade involved). The opinions expressed by the panel members on the matter are anonymous and the panel deliberations are secret.

(ix) Although the CONTRACTING PARTIES have never established precise deadlines for the different phases of the procedure, probably because the matters submitted to panels differ as to their complexity and their urgency, in most cases the proceedings of the panels have been completed within a reasonable period of time, extending from three to nine months.

The 1966 decision by the CONTRACTING PARTIES referred to in paragraph 2 above lays down in its paragraph 7 that the Panel shall report within a period of sixty days from the date the matter was referred to it.

7 The Council is empowered to act for the CONTRACTING PARTIES, in accordance with normal GATT practice.

${ }^{8}$ At the Review Session (1955) the proposal to institutionalize the procedures of panels was not adopted by CONTRACTING PARTIES mainly because they preferred to preserve the existing situation and not to establish judicial procedures which might put excessive strain on the GATT.

${ }^{9} 3$ BISD 14S/18. 


\section{MINISTERIAL DECLARATION OF 29 NOVEMBER 1982, DECISION ON DISPUTE SETTLEMENT}

\section{The CONTRACTING PARTIES:}

Agree that the Understanding on Notification, Consultation, Dispute Settlement and Surveillance negotiated during the Tokyo Round (hereinafter referred to as the "Understanding") provides the essential framework of procedures for the settlement of disputes among contracting parties and that no major change is required in this framework, but that there is scope for more effective use of the existing mechanism and for specific improvements in procedures to this end;

And agree further that:

(i) With reference to paragraph 8 of the Understanding, if a dispute is not resolved through consultations, any party to a dispute may, with the agreement of the other party, seek the good offices of the Director-General or of an individual or group of persons nominated by the Director-General. This conciliatory process would be carried out expeditiously, and the Director-General would inform the Council of the outcome of the conciliatory process. Conciliation proceedings, and in particular positions taken by the parties to the dispute during consultations, shall be confidential, and without prejudice to the rights of either party in any further proceedings under Article XXIII:2. It would remain open at any time during any conciliatory process for either party to the dispute to refer the matter to the CONTRACTING PARTIES.

(ii) In order to ensure more effective compliance with the provisions of paragraphs 11 and 12 of the Understanding, the Director-General shall inform the Council of any case in which it has not been found possible to meet the time-limits for the establishment of a panel.

(iii) With reference to paragraph 13 of the Understanding, contracting parties will cooperate effectively with the Director-General in making suitably qualified experts available to serve on panels. Where experts are not drawn from Geneva, any expenses, including travel and subsistence allowance, shall be met from the GATT budget.

(iv) The secretariat of GATT has the responsibility of assisting the panel, especially on the legal, historical and procedural aspects of the matters dealt with.

(v) The terms of reference of a panel should be formulated so as to permit a clear finding with respect to any contravention of GATT provisions and/or on the question of nullification and impairment of benefits. In terms of paragraph 16 of the Understanding, and after reviewing the facts of the case, the applicability of GATT provisions and the arguments advanced, the panel should come to such a finding. Where a finding establishing a contravention of GATT provisions or nullification or impairment is made, 
the panel should make such suggestions as appropriate for dealing with the matter as would assist the CONTRACTING PARTIES in making recommendations to the contracting parties which they consider to be concerned, or give a ruling on the matter, as appropriate.

(vi) Panels would aim to deliver their findings without undue delay, as provided in paragraph 20 of the Understanding. If a complete report cannot be made within the period foreseen in that paragraph, panels would be expected to so advise the Council and the report should be submitted as soon as possible thereafter.

(vii) Reports of panels should be given prompt consideration by the CONTRACTING PARTIES. Where a decision on the findings contained in a report calls for a ruling or a recommendation by the Council, the Council may allow the contracting party concerned a reasonable specified time to indicate what action it proposes to take with a view to a satisfactory settlement of the matter, before making any recommendation or ruling on the basis of the report.

(viii) The recommendation or ruling made by the CONTRACTING PARTIES shall be aimed at achieving a satisfactory settlement of the matter in accordance with GATT obligations. In furtherance of the provisions of paragraph 22 of the Understanding the Council shall periodically review the action taken pursuant to such recommendations. The contracting party to which such a recommendation has been addressed, shall report within a reasonable specified period on action taken or on its reasons for not implementing the recommendation or ruling by the CONTRACTING PARTIES. The contracting party bringing the case may also ask the CONTRACTING PARTIES to make suitable efforts with a view to finding an appropriate solution as provided in paragraph 22 of the Understanding.

(ix) The further action taken by the CONTRACTING PARTIES in the above circumstances might include a recommendation for compensatory adjustment with respect to other products or authorization for the suspension of such concessions or other obligations as foreseen in Article XXIII:2, as the CONTRACTING PARTIES may determine to be appropriate in the circumstances.

(x) The Parties to a dispute would fully participate in the consideration of the matter by the CONTRACTING PARTIES under paragraph (viii) above, including the consideration of any rulings or recommendations the CONTRACTING PARTIES might make pursuant to Article XXIII:2 of the General Agreement, and their views would be fully recorded. They would likewise participate and have their views recorded in the considerations of the further actions provided for under paragraphs (viii) and (ix) above. The CONTRACTING PARTIES reaffirmed that consensus will continue to be the traditional method of resolving disputes; however, they agreed that obstruction in the process of dispute settlement shall be avoided. 1 It is understood that decisions in this process cannot add to or diminish the rights and obligations provided in the General Agreement.

1 This does not prejudice the provisions on decision making in the General Agreement. 


\section{DECISION ON DISPUTE SETTLEMENT OF 30 NOVEMBER 1984}

\section{The CONTRACTING PARTIES adopted the following proposal in L/5718/Rev.1:}

At the 1982 Ministerial it was agreed that the Dispute Settlement "Understanding" provides the essential framework of procedures for the settlement of disputes among contracting parties and that no major change is required in this framework, but that there is scope for more effective use of the existing mechanism and for specific improvements in procedures to this end.

However, if improvement in the whole system is to be achieved, it is necessary not only to make specific procedural improvements, but also to obtain a clear-cut understanding by and commitment from the CONTRACTING PARTIES (or Signatories to the Codes) with respect to the nature and time-frame of (a) the panel process; (b) the decision on the dispute matter to he taken by the CONTRACTING PARTIES (or the Code Committee) on the basis of the panel's report; and (c) the follow-up to be given to that decision by the parties to the dispute.

A number of procedural problems related to the panel process have been encountered which can be addressed within the existing framework. Such problems include the formation of panels in a timely manner, and the timely completion of panel work. Although the "Understanding" provides guidelines for these procedures (thirty days for the formation of a panel and three to nine months to complete the panel's work), experience has shown these time targets are seldom met. These are only a couple of difficulties related to the dispute settlement mechanism, so addressing them alone will not cure all its deficiencies. However, procedural improvements can lead to improvements in the quality of panel reports. Therefore, the CONTRACTING PARTIES agree that, as a first step, the following approach should he adopted, on a trial basis, for a period of one year in order to continue the process of improving operation of the system.

Formation of panels

1. Contracting parties should indicate to the Director-General the names of persons they think qualified to serve as panelists, who are not presently affiliated with national administrations but who have a high degree of knowledge of international trade and experience of the GATT. These names should be used to develop a short roster of nongovernmental panelists to be agreed upon by the CONTRACTING PARTIES in consultation with the Director-General. The roster should be as representative as possible of contracting parties.

2. The Director-General should continue the practice of proposing panels composed preferably of governmental representatives but may also draw as necessary on persons on 
the approved roster. The parties should retain the ability to respond to the DirectorGeneral's proposal, but shall not oppose nominations except for compelling reasons.

3. In the event that panel composition cannot be agreed within thirty days after a matter is referred by the CONTRACTING PARTIES, the Director-General shall, at the request of either party and in consultation with the Chairman of the Council, complete the panel by appointing persons from the roster of nongovernmental panelists to resolve the deadlock, after consulting both parties.

Completion of panel work

1. Panels should continue to set their own working procedures and, where possible, panels should provide the parties to the dispute at the outset with a proposed calendar for the panel's work.

2. Where written submissions are requested from the parties, panels should set precise deadlines, and parties to a dispute should respect those deadlines. 


\section{ANEXO G - DECISÃO DE 1989}

\section{DECISION OF 12 APRIL 1989 ON IMPROVEMENTS TO THE GATT DISPUTE SETTLEMENT RULES AND PROCEDURES}

Following the meetings of the Trade Negotiations Committee at Ministerial level in December 1988 and at the level of high officials in April 1989, the CONTRACTING PARTIES to the General Agreement on Tariffs and Trade

Approve the improvements of the GATT dispute settlement rules and procedures set out below and their application on the basis set out in this Decision:

\section{A. General Provisions}

1. Contracting parties recognize that the dispute settlement system of GATT serves to preserve the rights and obligations of contracting parties under the General Agreement and to clarify the existing provisions of the General Agreement. It is a central element in providing security and predictability to the multilateral trading system.

2. Contracting parties agree that all solutions to matters formally raised under the GATT dispute settlement system under Articles XXII, XXIII and arbitration awards shall be consistent with the General Agreement and shall not nullify or impair benefits accruing to any contracting party under the General Agreement, nor impede the attainment of any objective of the General Agreement.

3. Contracting parties agree that the existing rules and procedures of the GATT in the field of dispute settlement shall continue. It is further agreed that the improvements set out below, which aim to ensure prompt and effective resolution of disputes to the benefit of all contracting parties, shall be applied on a trial basis from 1 May 1989 to the end of the Uruguay Round in respect of complaints brought during that period under Article XXII or XXIII; it is also agreed to keep the application of these improvements under review during the remainder of the Round and to decide on their adoption before the end of the Round; to continue negotiations with the aim of further improving and strengthening the GATT dispute settlement system taking into account the experience gained in the application of these improvements.

4. All the points set out in this Decision shall be applied without prejudice to any provision on special and differential treatment for developing contracting parties in the existing instruments on dispute settlement including the CONTRACTING PARTIES' Decision of 5 April 1966 (BISD 14S/18).

\section{B. Notification}

Mutually agreed solutions to matters formally raised under GATT Articles XXII and XXIII, as well as arbitration awards within GATT, must be notified to the Council where any contracting party may raise any point relating thereto. 


\section{Consultations}

1. If a request is made under Article XXII:1 or XXIII:1, the contracting party to which the request is made shall, unless otherwise mutually agreed, reply to the request within ten days after its receipt and shall enter into consultations in good faith within a period of no more than thirty days from the date of the request, with a view to reaching a mutually satisfactory solution. If the contracting party does not respond within ten days, or does not enter into consultations within a period of no more than thirty days, or a period otherwise mutually agreed, from the date of the request, then the contracting party that requested the holding of consultations may proceed directly to request the establishment of a panel or a working party.

2. If the consultations under Article XXII:1 or XXIII:1 fail to settle a dispute within sixty days after the request for consultations, the complaining party may request the establishment of a panel or a working party under Article XXIII:2. The complaining party may request a panel or a working party during the sixty-day period if the parties jointly consider that consultations have failed to settle the dispute.

3. Requests for consultations under Article XXII:1 or XXIII:1 shall be notified to the Council by the party which requests consultations. Any request for consultations shall be submitted in writing and shall give the reasons for the request.

4. In cases of urgency, including those which concern perishable goods en route, parties shall enter into consultations within a period of no more than ten days from the date of the request. If the consultations have failed to settle the dispute within a period of thirty days after the request, the complaining party may request the establishment of a panel or a working party.

\section{Good Offices, Conciliation, Mediation}

1. Good offices, conciliation and mediation are procedures that are undertaken voluntarily if the parties to the dispute so agree. They may be requested at any time by any party to a dispute. They may begin at any time and be terminated at any time. Once terminated, the complaining party can then proceed with a request for the establishment of a panel or a working party under Article XXIII:2. When good offices, conciliation or mediation are entered into within sixty days of a request for consultations, the complaining party must allow a period of sixty days from the date of the request for consultations before requesting the establishment of a panel or working party. The complaining party may request a panel or a working party during the sixty days if the parties to the dispute jointly consider that the good offices, conciliation or mediation process has failed to settle the dispute.

2. If the parties to a dispute agree, procedures for good offices, conciliation or mediation may continue while the panel or working party process proceeds.

3. The Director-General may, acting in an ex officio capacity, offer his good offices, conciliation or mediation with the view to assisting contracting parties to settle a dispute.

\section{E. Arbitration}

1. Expeditious arbitration within GATT as an alternative means of dispute settlement can facilitate the solution of certain disputes that concern issues that are clearly defined by both parties.

2. Resort to arbitration shall be subject to mutual agreement of the parties which shall agree on the procedures to be followed. Agreements to resort to arbitration shall be notified 
to all contracting parties sufficiently in advance of the actual commencement of the arbitration process.

3. Other contracting parties may become party to an arbitration proceeding upon the agreement of the parties which have agreed to have recourse to arbitration. The parties to the proceeding shall agree to abide by the arbitration award.

F. Panel and Working Party Procedures

(a) Establishment of a Panel or a Working Party

The request for a panel or a working party shall be made in writing. It shall indicate whether consultations were held, and provide a brief summary of the factual and legal basis of the complaint sufficient to present the problem clearly. In case the applicant requests the establishment of a panel or a working party with other than standard terms of reference, the written request shall include the proposed text of special terms of reference. If the complaining party so requests, a decision to establish a panel or working party shall be taken at the latest at the Council meeting following that at which the request first appeared as an item on the Council's regular agenda, unless at that meeting the Council decides otherwise. ${ }^{1}$

(b) Standard Terms of Reference

1. Panels shall have the following terms of reference unless the parties to the dispute agree otherwise within twenty days from the establishment of the panel:

"To examine, in the light of the relevant GATT provisions, the matter referred to the CONTRACTING PARTIES by (name of contracting party) in document $\mathrm{L} / \ldots$ and to make such findings as will assist the CONTRACTING PARTIES in making the recommendations or in giving the rulings provided for in Article XXIII:2".

2. In establishing a panel, the Council may authorize its Chairman to draw up the terms of reference of the panel in consultation with the parties subject to the provisions of the preceding paragraph. The terms of reference thus drawn up shall be circulated to all contracting parties. If other than standard terms of reference are agreed upon, any contracting party may raise any point relating thereto in the Council.

(c) Composition of Panels

1. Contracting parties shall undertake, as a general rule, to permit their representatives to serve as panel members.

2. Panels shall be composed of well-qualified governmental and/or non-governmental individuals.

3. The roster of non-governmental panelists shall be expanded and improved. To this end, contracting parties may nominate individuals to serve on panels and shall provide relevant information on their nominee's knowledge of international trade and of the GATT.

4. Panels shall be composed of three members unless the parties to the dispute agree, within ten days from the establishment of the panel, to a panel composed of five members.

5. If there is no agreement on the members within twenty days from the establishment of a panel, at the request of either party, the Director-General, in consultation with the Chairman of the Council, shall form the panel by appointing the panelists whom he considers most appropriate, after consulting both parties. The Director- General shall 
inform the contracting parties of the composition of the panel thus formed no later than ten days from the date he receives such a request.

\section{(d) Procedures for Multiple Complainants}

1. Where more than one contracting party requests the establishment of a panel related to the same matter, a single panel may be established to examine these complaints taking into account the rights of all parties concerned. A single panel should be established to examine such complaints whenever feasible.

2. The single panel will organize its examination and present its findings to the Council so that the rights which the parties to the dispute would have enjoyed had separate panels examined the complaints are in no way impaired. If one of the parties to the dispute so requests, the panel will submit separate reports on the dispute concerned. The written submissions by each of the complainants will be made available to the other complainants, and each complainant will have the right to be present when one of the other complainants presents its view to the panel.

3. If more than one panel is established to examine the complaints related to the same matter, to the greatest extent possible the same persons shall serve as panelists on each of the separate panels and the timetable for the panel process in such disputes shall be harmonized.

\section{(e) Third Contracting Parties}

1. The interests of the parties to a dispute and those of other contracting parties shall be fully taken into account during the panel process.

2. Any third contracting party having a substantial interest in a matter before a panel, and having notified this to the Council, shall have an opportunity to be heard by the panel and to make written submissions to the panel. These submissions shall also be given to the parties to the dispute and shall be reflected in the panel report.

3. At the request of the third contracting party, the panel may grant the third contracting party access to the written submissions to the panel by those parties to the dispute which have agreed to the disclosure of their respective submission to the third contracting party.

(f) Time Devoted to Various Phases of a Panel

1. Panel procedures should provide sufficient flexibility so as to ensure high-quality panel reports, while not unduly delaying the panel process.

2. Panels shall follow the Suggested Working Procedures found in the July 1985 note of the Office of Legal Affairs unless the members of the panel agree otherwise after consulting the parties to the dispute. After consulting the parties, the panel members shall, as soon as practicable and whenever possible within one week after the composition and terms of reference of the panel have been agreed upon, fix the timetable for the panel process at least until its first substantive meeting.

3. In determining the timetable for the panel process, the panel shall provide sufficient time for the parties to the dispute to prepare their submissions.

4. Each party to the dispute shall deposit its written submissions with the Secretariat for immediate transmission to the panel and to the other party or parties to the dispute. The complaining party shall submit its first submission in advance of the responding party's first submission unless the panel decides, in fixing the timetable referred to in the second paragraph of this section and after consultations with the parties to the dispute, that the parties should submit their first submissions simultaneously. When there are sequential 
arrangements for the deposit of first submissions, the panel shall establish a firm time period for receipt of the responding party's submission. Any subsequent written submissions shall be submitted simultaneously.

5. In order to make the procedures more efficient, the period in which the panel shall conduct its examination, from the time the composition and terms of reference of the panel have been agreed upon to the time when the final report is provided to the parties to the dispute, shall, as a general rule, not exceed six months. In cases of urgency, including those relating to perishable goods, the panel shall aim to provide its report to the parties within three months.

6. When the panel considers that it cannot provide its report within six months, or within three months in cases of urgency, it shall inform the Council in writing of the reasons for the delay together with an estimate of the period within which it will submit its report. In no case should the period from the establishment of the panel to the submission of the report to the contracting parties exceed nine months.

7. In the context of consultations involving a measure taken by a developing contracting party, the parties may agree to extend the periods established in paragraphs 2 and 4 of Section C. If, after the relevant period has elapsed, the parties cannot agree that the consultations have concluded, the Chairman of the Council shall decide, after consultation with the parties, whether to extend the relevant period and, if so, for how long. In addition, in examining a complaint against a developing contracting party, the panel shall accord sufficient time for the developing contracting party to prepare and present its argumentation. The provisions of paragraph 4 of Section $\mathrm{G}$ are not affected by any action pursuant to this paragraph.

\section{G. Adoption of Panel Reports}

1. In order to provide sufficient time for the members of the Council to consider panel reports, the reports shall not be considered for adoption by the Council until thirty days after they have been issued to the contracting parties.

2. Contracting parties having objections to panel reports shall give written reasons to explain their objections for circulation at least ten days prior to the Council meeting at which the panel report will be considered.

3. The parties to a dispute shall have the right to participate fully in the consideration of the panel report by the Council, and their views shall be fully recorded. The practice of adopting panel reports by consensus shall be continued, without prejudice to the GATT provisions on decision-making which remain applicable. However, the delaying of the process of dispute settlement shall be avoided.

4. The period from the request under Article XXII:1 or Article XXIII:1 until the Council takes a decision on the panel report shall not, unless agreed to by the parties, exceed fifteen months. The provisions of this paragraph shall not affect the provisions of paragraph 6 of Section $F(f)$.

\section{H. Technical Assistance}

1. While the Secretariat assists contracting parties in respect of dispute settlement at their request, there may also be a need to provide additional legal advice and assistance in respect of dispute settlement to developing contracting parties. To this end, the Secretariat shall make available a qualified legal expert within the Technical Co-operation Division to any developing contracting party which so requests. This expert shall assist the developing contracting party in a manner ensuring the continued impartiality of the Secretariat. 
2. The Secretariat shall conduct special training courses for interested contracting parties concerning GATT dispute settlement procedures and practices so as to enable contracting parties' experts to be better informed in this regard.

I. Surveillance of Implementation of Recommendations and Rulings

1. Prompt compliance with recommendations or rulings of the CONTRACTING PARTIES under Article XXIII is essential in order to ensure effective resolution of disputes to the benefit of all contracting parties.

2. The contracting party concerned shall inform the Council of its intentions in respect of implementation of the recommendations or rulings. If it is impracticable to comply immediately with the recommendations or rulings, the contracting party concerned shall have a reasonable period of time in which to do so.

3. The Council shall monitor the implementation of recommendations or rulings adopted under Article XXIII:2. The issue of implementation of the recommendations or rulings may be raised at the Council by any contracting party at any time following their adoption. Unless the Council decides otherwise, the issue of implementation of the recommendations or rulings shall be on the agenda of the Council meeting after six months following their adoption and shall remain on the Council's agenda until the issue is resolved. At least ten days prior to each such Council meeting, the contracting party concerned shall provide the Council with a status report in writing of its progress in the implementation of the panel recommendations or rulings.

4. In cases brought by developing contracting parties, the Council shall consider what further action it might take which would be appropriate to the circumstances, in conformity with paragraphs 21 and 23 of the 1979 Understanding regarding Notification, Consultation, Dispute Settlement and Surveillance (BISD 26S/214).

1 References to the Council, made in this paragraph as well as in the following paragraphs, are without prejudice to the competence of the CONTRACTING PARTIES, for which the Council is empowered to act in accordance with normal GATT practice (BISD 26S/215). 
DECISION OF 22 FEBRUARY 1994 ON EXTENSION OF THE APRIL 1989

DECISION ON IMPROVEMENTS TO THE GATT DISPUTE SETTLEMENT

RULES AND PROCEDURES

(L/7416)

The CONTRACTING PARTIES,

Recalling their Decision of 12 April 1989 (BISD 36S/61),

Noting that the improvements to the GATT dispute settlement rules and procedures are being applied on a trial basis until the end of the Uruguay Round and that a decision on their adoption should be taken before the end of the Round,

Considering that the continuation of the improved rules and procedures is necessary for the effectiveness of the dispute settlement mechanism,

Decide,

To keep the above-mentioned improvements in effect until the entry into force of the Understanding on Rules and Procedures Governing the Settlement of Disputes contained in Annex 2 of the Agreement Establishing the World Trade Organization (MTN/FA, II). 